
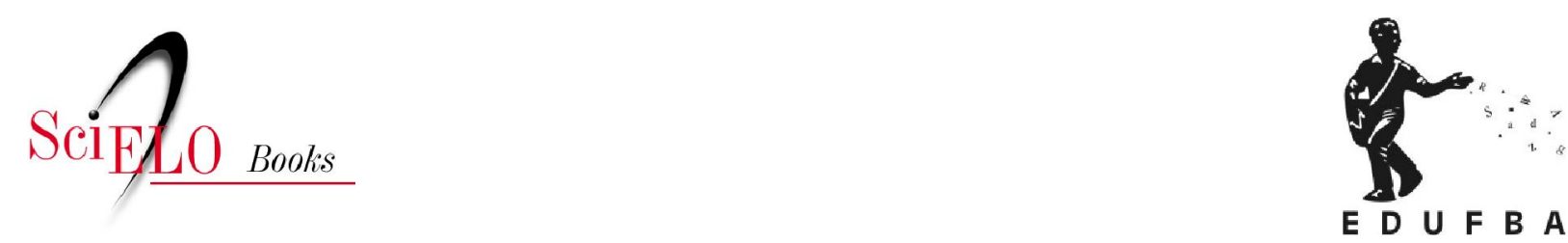

\title{
Mitos e outras narrativas Kamayura
}

\author{
Pedro Agostinho
}

AGOSTINHO, P. Mitos e outras narrativas Kamayura [online]. 2nd ed. Salvador: EDUFBA, 2009, 210p. ISBN 978-85-232-1203-2. Available from SciELO Books $<$ http://books.scielo.org $>$.

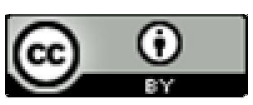

All the contents of this work, except where otherwise noted, is licensed under a Creative Commons Attribution 4.0 International license.

Todo o conteúdo deste trabalho, exceto quando houver ressalva, é publicado sob a licença Creative Commons Atribição 4.0.

Todo el contenido de esta obra, excepto donde se indique lo contrario, está bajo licencia de la licencia $\underline{\text { Creative }}$ Commons Reconocimento 4.0. 


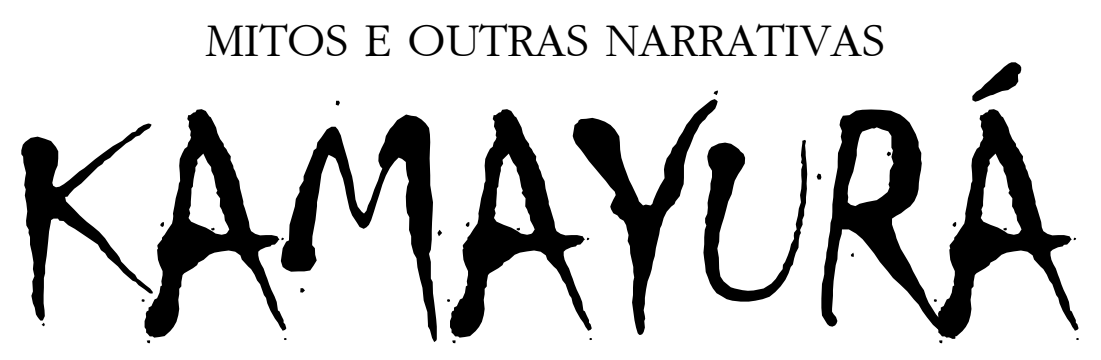




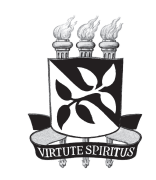

UNIVERSIDADE FEDERAL DA BAHIA

Reitor

Naomar Monteiro de Almeida-Filho

Vice-Reitor

Francisco José Gomes Mesquita

EDITORA DA UNIVERSIDADE FEDERAL DA BAHIA

Diretora

Flávia Goullart Mota Garcia Rosa

Conselho Editorial

Titulares

Ângelo Szaniecki Perret Serpa

Caiuby Alves da Costa

Charbel Ninõ El-Hani

Dante Eustachio Lucchesi Ramacciotti

José Teixeira Cavalcante Filho

Maria do Carmo Soares Freitas

Suplentes
Alberto Brum Novaes

Antônio Fernando Guerreiro de Freitas

Armindo Jorge de Carvalho Bião

Evelina de Carvalho Sá Hoisel

Cleise Furtado Mendes

Maria Vidal de Negreiros Camargo 
PEDRO AGOSTINHO

MITOS E OUTRAS NARRATIVAS

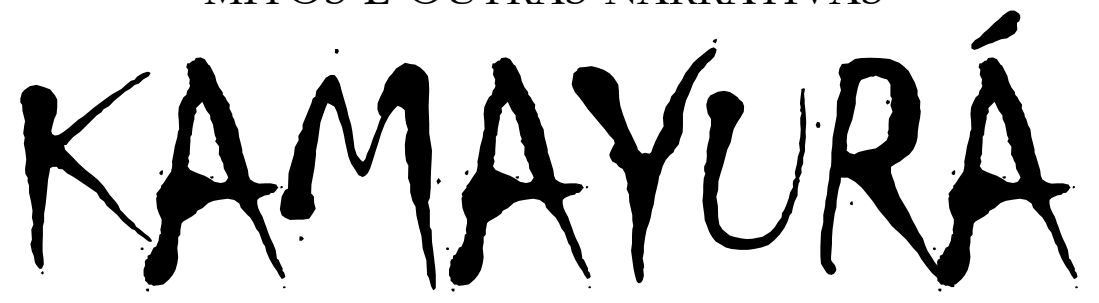

$2^{\mathrm{a}}$ edição

EDUFBA

Salvador, 2009 
(C)2009, By Pedro Agostinho

Direitos de edição cedidos à

Editora da Universidade Federal da Bahia - EDUFBA

Feito o depósito legal.

\author{
Revisão \\ Rosa Virgínia Mattos e Silva \\ Editoração Eletrônica e Capa \\ Rodrigo Oyarzábal Schlabitz
}

Sistema de Bibliotecas - UFBA

Agostinho, Pedro.

Mitos e outras narrativas Kamayura / Pedro Agostinho. - $2^{\mathrm{a}}$ edição - Salvador:

EDUFBA, 2009. 210 p.

ISBN: 978-85-232-0590-4

1. Folclore indígena - América do Sul. 2. Folclore - Lendas. 3. Índios da América do Sul - Vida e costumes sociais. I. Título.

CDD - 398.208998
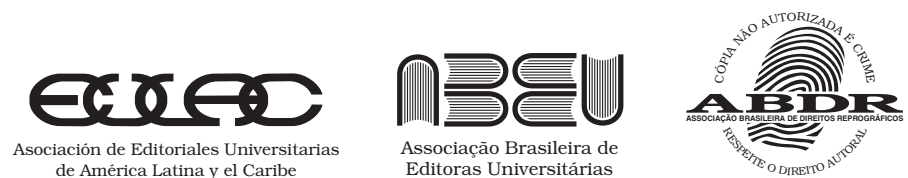

EDUFBA

Rua Barão de Jeremoabo, s/n - Campus de Ondina,

40170-115 Salvador-BA

Tel/fax: (71) 3283-6164

www.edufba.ufba.br

edufba@ufba.br 
A Tuvulé e Tawapè, intérpretes, informantes, amigos. 



\section{SUMÁRIO}

\section{Parte I}

\section{INTRODUÇÃO METODOLÓGICA}

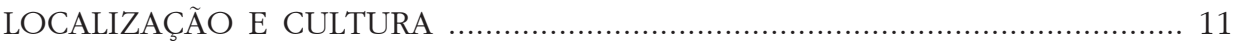

A MITOLOGIA XINGUANA: ESTADO DOS CONHECIMENTOS ……………...... 16

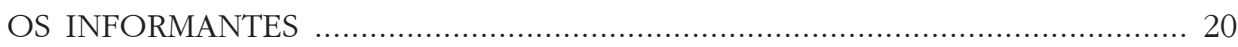

MÉTODOS DE CAMPO E CRITÉRIOS DA EDIÇÃO …………………............... 26

\section{Parte II}

MITOS E OUTRAS NARRATIVAS KAMAYURÁ

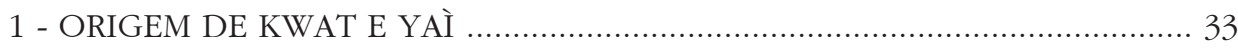

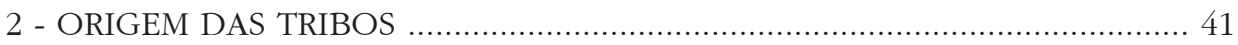

3 - ORIGEM DE KWAT E YAİ E DO KWARÌP ................................................ 41

4 - COMO MAVUTSINI(N) COMEÇOU KWARÌP ………................................... 46

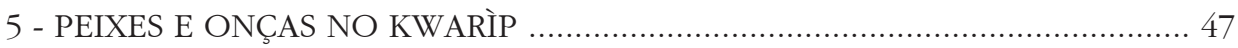

6 - MAVUTSINI(N) TENTA RESSUSCITAR FILHOS SEUS .................................. 51

7 - COMO MAVUTSINI(N) FEZ PÁSSAROS E OUTROS BICHOS ........................ 51

8 - COMO MAVUTSINI(N) COMEÇOU PAJÉ ……………................................ 51

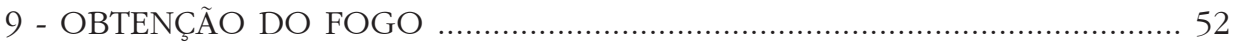

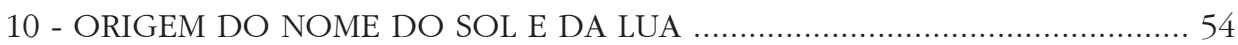

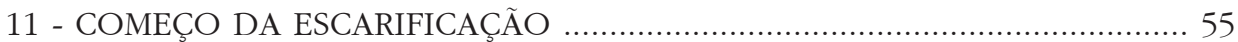

12 - KWAT COMEÇA AS RELAÇÕES SEXUAIS ………………………….......... 55

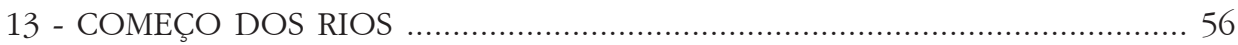

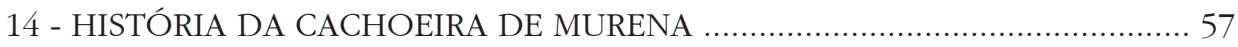

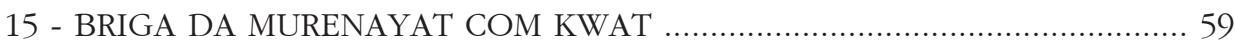

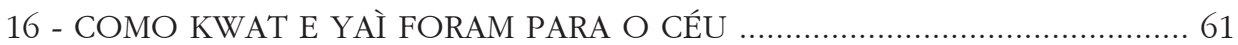

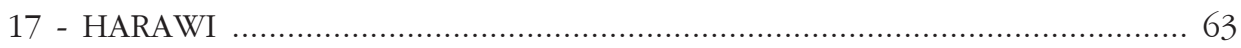

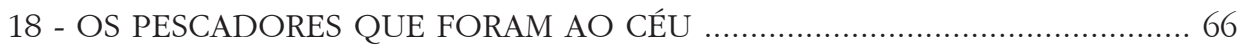

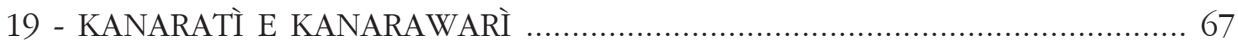

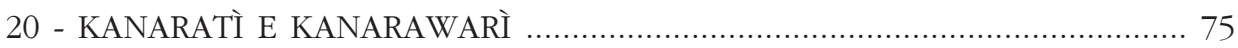

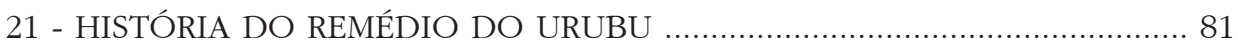

22 - COMO O URUBU ARRANJOU JENIPAPO …………………………......... 83

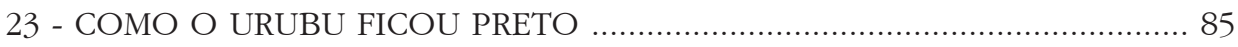

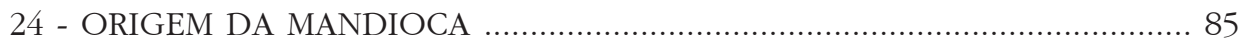

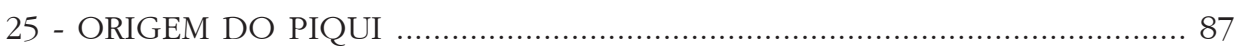

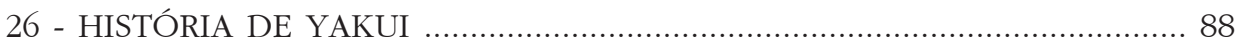

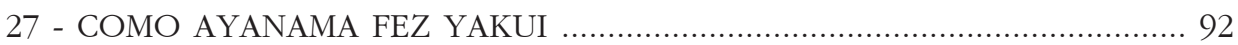


28 - HISTÓRIA DA CASA DE YAKUI …........................................................... 96

29 - OS MAMA'E(N) QUE ROUBARAM URUCU ............................................. 100

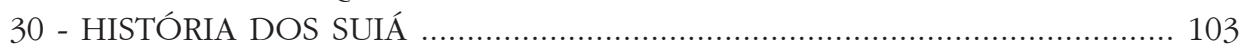

31 - O MENINO-PEIXE .............................................................................. 104

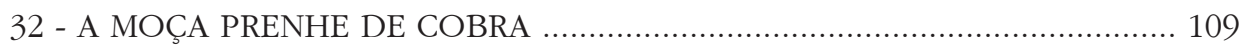

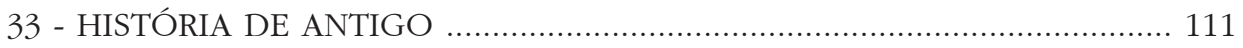

34 - HISTÓRIA DA MOÇA QUE QUERIA NAMORAR ..................................... 113

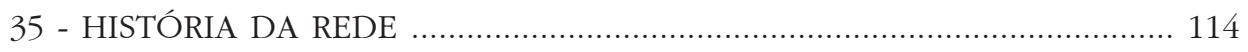

36 - HISTÓRIA DE PANELA _....................................................................... 116

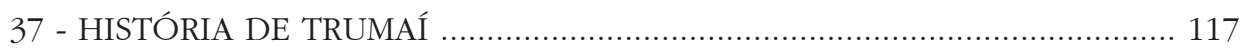

38 - OS TRUMAÍ APRENDEM YAWARI COM AYANAMA ................................ 119

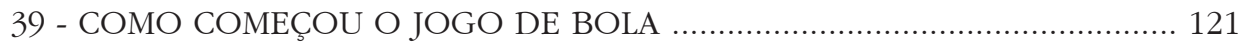

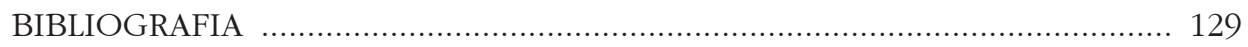

ÍNDICE DAS ESTAMPAS, FIGURAS E QUADROS ........................................ 132

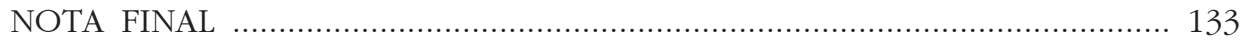

\section{ESTUDO PRELIMINAR SOBRE O MITO DE ORIGENS}

XINGUANO. COMENTÁRIO A UMA VARIANTE AWETÏ

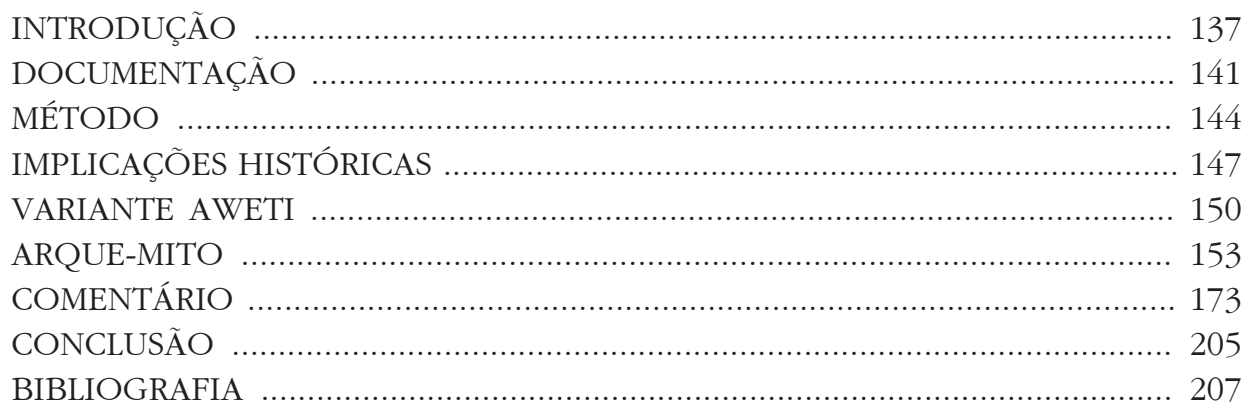


Parte I

INTRODUÇÃO METODOLÓGICA 


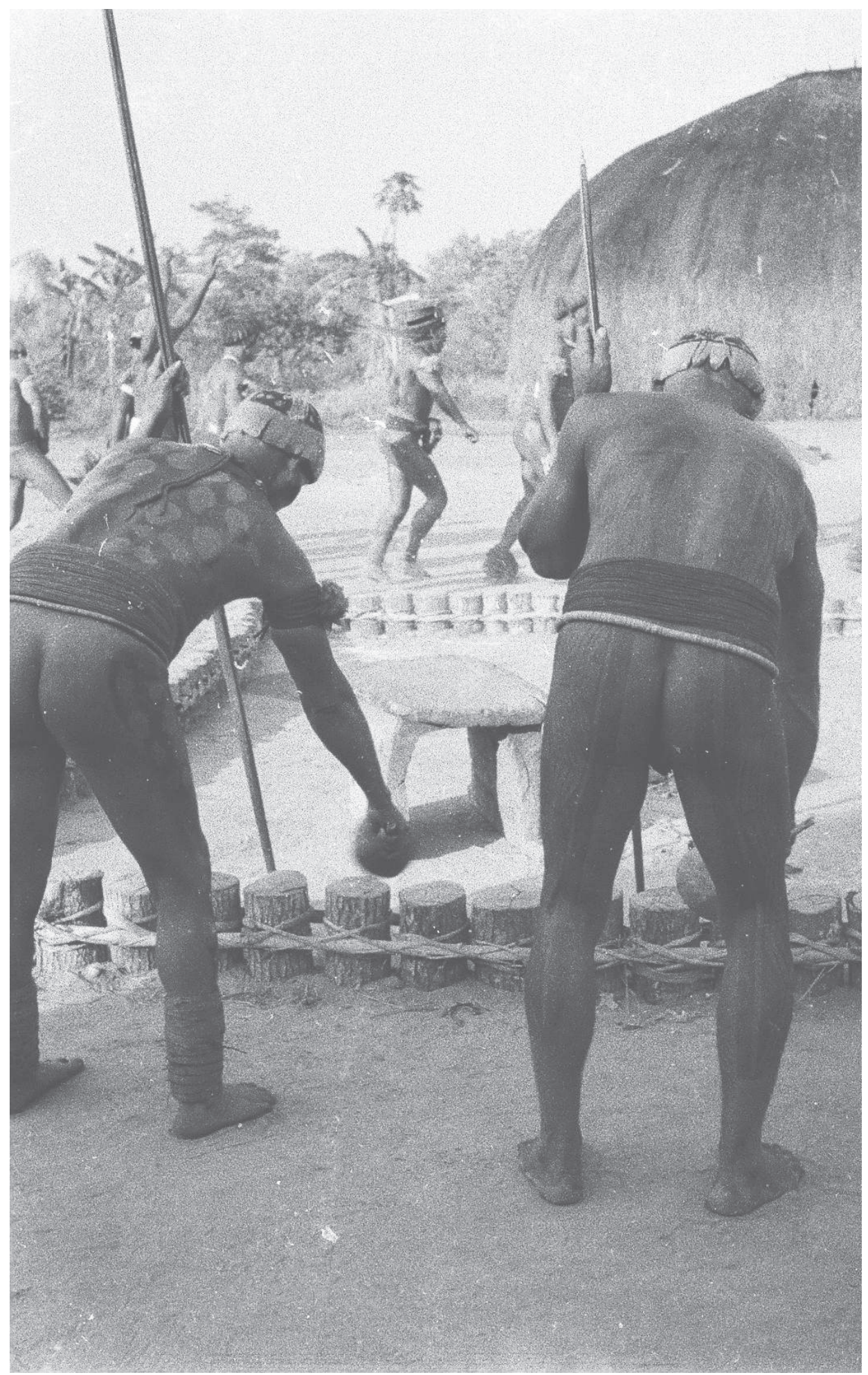




\section{LOCALIZAÇÃO E CULTURA}

Os índios Kamayurá, que se auto denominam Apiap, habitam uma só aldeia situada no extremo sul da Lagoa Ipavu (aprox. 53 $25^{\prime}$ W. Gr., $12^{\circ} 5^{\prime}$ lat. Sul), em terras da margem esquerda do Rio Kuluene, na Bacia dos formadores do Xingu. Guardam tradicionalmente a lembrança de um movimento migratório que, vindo do norte, teria deixado como vestígio um sítio abandonado no baixo Suiá-Missu (Galvão 1953:8), seguindo depois para sul, ao longo, com é de presumir, do Xingu e depois do próprio Kuluene, até Ipavu.

Aí foram encontrados pela segunda expedição de von den Steinen (1887), o qual, quando de sua primeira viagem pela região, tinha recolhido sobre eles as primeiras notícias históricas. Achavam-se dispersos por quatro aldeias, todas próximas umas das outras, e numa delas haviam elevado uma casa considerada por aquele autor "talvez a mais bem construída... em todo o Xingu, alta e espaçosa" (1940: 148-152). Nesse local planejam vir a concentrar o resto da população, em futuro não muito distante.

A ocupação de Ipavu, apreciavelmente longa, é atestada não apenas pela memória tribal, como pelo grande número de antigos lugares de habitação que aí existem e são indicados pelos índios; sua distribuição não se restringe à margem meridional da lagoa, mas abrange a oriental e a ocidental. Isto, somado aos restantes indícios, permite considerar, provisoriamente, fidedigno o que se sabe quanto aos possíveis movimentos da tribo. Os quais, note-se, e a julgar pelas distâncias entre esses sítios arqueológicos, devem ter sido de reduzida amplitude espacial nos tempos mais recentes. As escavações de Simões (1967) e observações que fizemos no campo provam que se pode aceitar como fundamentados os conhecimentos indígenas quanto a essas desaparecidas povoações; três ou quatro delas foram contemporâneas e, tendo em vista sua posição e o tempo decor- 
rido desde a passagem de von den Steinen, é de suspeitar que se trate das visitadas por ele e seus companheiros.

Sendo dos últimos grupos a ingressar no que Galvão (1960) definiu como a "área cultural do Alto Xingu", os Kamayurá estabeleceram-se na zona da referida área onde as relações intertribais eram mais tensas e os conflitos mais freqüentes. Parece ter sido o receio que se seguiu a um ataque Suiá que os levou a se transferirem temporariamente mais para Sul, para perto do Rio Tiwatiwari, talvez nos meados da década de 40. Em 1947, Lima (1955:164) encontrou aí uma aldeia em construção, e, no ano seguinte, Oberg (1953:13) observava-a com seis casas de moradia e um rancho onde se guardavam as flautas yakuíe outros objetos rituais. Mas nem então Ipavu foi deixada por completo, continuando com certa importância e ritual, mantendo-se ali casas, seputando-se os mortos e fazendo-se a colheita de pique (Oberg 1953:17-18). Tal estado de coisas teve, porém, pouca duração, e em 1953 Lima já registrava o abandono do Tîwatiwari e o retorno de Ipavu.

Este foi definitivo, e das razões para mudança conhecemos apenas as que nos foram adiantadas pelos índios: apontam a abundância de mosquitos, que para eles foi conseqüência de causas sobrenaturais, especificamente das relações de um dos pajés com seus mama'e $(n)$ ou espíritos tutelares. No que dizem há um fundo de verdade, dada a proximidade do rio e, pior, de terrenos pantanosos ou periodicamente inundados. Mas deve ter pesado muito o regresso a um território tradicional, bem conhecido, razoavelmente seguro - especialmente depois do surgimento dos acampamentos Expedição Roncador-Xingu -, rico em terras e outros recursos naturais, como os piquis e as mangabeiras já notadas por von den Steinen (1940:148).

Em 1963, a situação era como a que acabamos de descrever, com a aldeia de Ipavu no local que ocupava em 1952, ou próximo a ele - não pudemos verificar isto com absoluta precisão -, e a do Tîwatiwari sem ser repovoada (Simões Ms.). Isto mantinha-se em 1965 e 1966, quando estivemos no campo: havia um total de 6 casas - uma das quais apresentando curiosa combinação de padrões indígenas e caboclos - e um tapwi $(n)$ ou rancho das flautas. Discutiam então a hipótese de nova mudança, para mais perto da lagoa, numa deslocação curta que não ultrapassaria poucas centenas de metros; segundo eles, justificava sua necessidade o envelhecimento das casas. Mas também ficaria facilitado o transporte da água pelas mulheres e o da mandioca desde as canoas. Efetivamente, em 1969 já uma casa se erguia no local escolhido a meio quilômetro, mais ou menos, do anterior; dado o ritmo bastante lento a que obedece uma transferência de aldeia, é de esperar que dentro de dois ou três anos ela se ache completada. 
Os Kamayurá contavam, em 1963, com uma população de 115 indivíduos de ambos os sexos, 96 deles fixos em Ipavu e os 17 restantes oscilando entre a aldeia e o Posto Xingu, da FAB, no Jacaré (Simões 1963a). Em 1965, havia 118 habitantes na aldeia, 65 deles do sexo masculino e 53 do feminino (Oliveira 1965). Comparados estes números com os de Lima (1955), vê-se que, em 1947, existiam 110 indivíduos, igualmente distribuídos por cada sexo. Teria havido, portanto, ligeiro aumento demográfico, em termos absolutos, mas os dados são insuficientes para avaliar se ele se deu por crescimento vegetativo ou devido aos tão freqüentes casamentos intertribais; estes implicam, na maioria das vezes, em residência matrilocal temporária, seguida de patrilocalidade, o que evidentemente se reflete na quantidade de habitantes recenseados. Bom exemplo é a situação populacional da aldeia em 1969: o total de 119 indivíduos distribuía-se entre 56 do sexo feminino e 63 do sexo masculino; desse total, 7 mulheres e um homem eram de outras tribos, mas residiam, por casamento, em Ipavu. O único homem Yawalapiti; quatro das mulheres, Awetï, duas, Mehináku, e uma, Trumaí. Por outro lado, 7 homens e 7 mulheres Kamayurá achavam-se dispersos, graças a casamentos, por outras aldeias, com uma exceção, que é a de um rapaz solteiro trabalhando para a FAB (Silva Ms.).

Não é, no entanto, modificada a composição racial do grupo por estes casamentos, uma vez que os xinguanos apresentam um tipo físico bastante uniforme (com a possível discrepância dos Trumaí) e pertencem ao mesmo grupo sangüíneo (Newman 1953:134; Lima 1950 b).

Linguisticamente Tupi, estes índios classificam-se, sob o ponto de vista cultural, como "de Floresta Tropical", muito embora lhes faltem certos elementos diagnósticos, como o tipiti (a mandioca é espremida numa esteirinha, tuavi); e a canoa monóxila, que também é feita de casca de jatobá. Os tipos monóxilos introduzidos são de origem juruna e carajá, com predominância do primeiro.

A economia baseia-se numa agricultura de roças cujo principal produto é a mandioca brava (Maniboc utilissima Pohl), e na pesca, sendo quase nulo o recurso à caça. Nas estações próprias, a safra de piqui, a das mangabas, a desova dos tracajá e o aparecimento de grandes gafanhotos trazem alguma variedade e uma dieta de si monótona. Quanto à aldeia, tem planta irregularmente circular, com casas dispostas em torno de um terreiro central, onde fica a casa das flautas e são enterrados os mortos. Conformando-se em tudo ao padrão xinguano, a aldeia costuma incluir uma gaiola cônica com uma harpia (Harpia harpija), cujas penas se destinam a enfeites e à emplumação de flechas. As casas são ocupadas por 
famílias extensas lideradas por um homem, geralmente da classe dos morerekwat, à qual estão afetas certas prerrogativas cerimoniais e de prestígio, e importante papel na manutenção da coesão tribal e do status de chefia. Tem esta, aliás, presentemente, pouco poder coativo, e assenta mais na capacidade de liderança do morerekwat do que em normas institucionalizadas, ou em ser viável a aplicação de sanções pelo detentor do poder. O "capitão" da aldeia seria idealmente um morerekwat, intervindo na sua designação fatores de herança, descendência, capacidade e prestígio pessoal (Galvão 1953:23-28).

Faltando, porém, um consenso social favorável, ou surgindo intrigas derivadas de dissensões internas, sua posição pode ver-se seriamente abalada. Testemunhamos recentemente a perda da chefia por aquele que era o chefe "legítimo", em resultado da conjunção de uma série de fatores de ordem externa e interna, muitos deles relacionados com o contato com o mundo civilizado. Nesta ocasião, quem lhe ocupou a posição foi um homem bastante jovem, atento para a introdução de mudanças na vida tribal, principalmente no que se refere a técnicas - sendo de notar que não era sequer cabeça de família extensa. Não se deve, entretanto, perder de vista o fato de que três anos mais tarde, isto é, em 1969, já periclitava seu status e era com dificuldade que mantinha alguma autoridade. Mas, até agora, não se pode de forma alguma considerar resolvido o caso, que se arrasta há uns quatro anos.

O sistema de parentesco é de descendência bilateral, classificando juntos o pai e os irmãos do pai, a mãe e as irmãs da mãe, e distinguindo com termos especiais a irmã do pai e o irmão da mãe. Irmãos, primos paralelos e primos cruzados são "irmãos" e "irmãs", mas o casamento, impossivel entre os dois primeiros, é considerado preferencial entre os terceiros. Filhos dos irmãos e primos paralelos são considerados "filhos", mas filhos dos primos cruzados entram na categoria de "sobrinhos", assim como os filhos da irmã. Os membros da segunda geração ascendente são considerados "avós", discriminando-se o sexo, e os da segunda geração são englobados num único termo. Relações de evitação estendem-se aos cunhados e aos sogros, reais ou classificatórios, de ambos os sexos, sendo que Galvão verificou relações jocosas entre primos cruzados de sexo oposto, sob uma forma que considerou atenuada: aliás, isto enquadra-se na lógica do sistema, pois esses primos são, respectivamente, cunhados e cônjuges em potencial (Galvão 1953:28-9).

São constantes e pacíficos os contatos com as outras sociedades nativas do Alto Xingu, embora sob uma capa de cordialidade ostensiva se possam descobrir indícios de rivalidade latente e de acumulação de tensões. Estas encontram escape nos jogos competitivos, em especial durante o período 
cerimonial da estação seca, jogos esses que constituem, com os casamentos, as festas e o comércio, os principais mecanismos de interação intertribal.

A “compressão cultural” a que foram submetidas (Galvão 1953:10), os contatos freqüentes e seu caráter pacífico facilitaram a aculturação entre as tribos xinguanas, tendo-se chegado a tal grau de uniformidade cultural, que restam apenas, como marca mais evidente das identidades étnicas, as várias línguas. Isto não implica numa igualdade total das normas que lhes regem a vida social; mas as diferenças são tão pequenas, que se têm de considerar como variantes de uma mesma cultura. O comércio que se desenvolveu e que veio desempenhando importante função nas relações intertribais assenta numa especialização na manufatura de certos objetos; sendo que essa função aparenta ser não tanto econômica quanto social e ideológica, isto adquire marcado relevo, pois no mito de origem os objetos de especialização ergológica ascendem à categoria de traços distintivos de cada uma das tribos. Isso torna-se óbvio com a leitura desse texto (mito 2), e ainda mais óbvio se o compararmos com suas outras versões conhecidas ${ }^{1}$.

Dessa comparação e análise, e do mais que se sabe sobre o assunto, tira-se a convicção de que, nos aspectos religiosos fundamentais da cultuara xinguana, se repete a uniformidade verificada naqueles de que tratamos antes. Os rituais ligados à casa das flautas, onde estas são tocadas fora das vistas e proibidas às mulheres; a comemoração no Kwarìp do mito das origens; as danças com máscaras; o forte desenvolvimento do xamanismo; os enfeites e pinturas usados nos cerimoniais; a sepultura dos morerekwat, delimitada por uma estacada quase rasa com o chão - tudo isso é comum e lhes dá características próprias.

Apesar disso, em termos lingüísticos, políticos e sociais, a aldeia Kamayurá constitui-se numa entidade autônoma, ou melhor, pretensamente autônoma, uma vez que os laços estabelecidos com suas vizinhas tenderiam a integrá-la numa sociedade mais ampla e em vias de formação. Abrangeria ela os grupos culturalmente xinguanos. É discutível que caminho tomará tal processo, face ao paulatino aumento dos contatos com a civilização, ao gradual envolvimento pela sociedade brasileira, e às correspondentes mudanças de ordem social e cultural. Os efeitos fazem-se sentir, predominantemente, nos sistemas adaptativo

\footnotetext{
${ }^{1}$ Para os Kamayurá, v. Oberg 1953:30, Junqueira 1966:1; Bakiri, Steinen 1940:483-485, 1942:334-337; Trumaí, Murphy \& Quain 1955:74-75; Awetì, notas pessoais de campo; Kalapálo, Carvalho 1951:1625. Cunha 1960:117-118. Temos motivos para crer que a versão pelo último autor apresentada como Kalapálo, seja na verdade kamayurá: dá como herói cultural Mavutsini(n) (denom. kamayurá), enquanto os Kalapálo lhe chamam Kuantun (Carvalho, IBID.) ou kwatingi (obs. Pess.). V., ainda, a excelente coletânea dos irmãos Villas Boas (1970).
} 
e associativo. Mas, como entre as esferas atingidas figura a da especialização e trocas intertribais (Galvão e Simões 1964:147-148; Schaden 1965:84-87), é previsível que venha a ser alterada a tendência, a que aludimos, para a formação de uma sociedade indígena multilingüística. Em que sentido, só os desenvolvimentos futuros da situação o poderão dizer.

\section{A MITOLOGIA XINGUANA: ESTADO DOS CONHECIMENTOS}

Pelo que sobre eles se tem escrito e por circunstâncias históricas e geográficas que facilitaram seu estudo, os Kamayurá entram no rol das tribos xinguanas mais bem conhecidas sob uma perspectiva antropológica moderna. Neste aspecto, com eles só rivalizam os Trumaí, Kuikuro e Kalapálo, graças aos trabalhos de campo, respectivamente, de Buell Quain, de Gertrude Dole e Robert Carneiro, e de Ellen Becker. Aos Kamayurá dedicaram-se, entre outros, Galvão, Oberg, Laraia e Junqueira, norteados por interesses pela estrutura social, pela mudança cultural, pelo sistema de valores e também pelos fatos econômicos, seja referentes à produção, seja à circulação de bens.

A literatura anterior, sobretudo a derivada das sucessivas expedições alemãs dos começos deste a fins do século passado, rica e volumosa, orientava suas preocupações para problemas de ordem psicológica, histórica-cultural e ergológica, a que não andavam estranhos, por outro lado, esquemas evolucionistas. Estava, portanto, bem de acordo com as questões científicas que se punham na época nos países em que foi escrita, e, dentro dessa orientação, devemos-lhe clássicos da etnografia. Não só do Xingu, mas do Brasil: basta lembrar as obras de von den Steinen (1940, 1942) e de Max Schmidt (1942). Não surpreende, assim, que sejam desta altura os primeiros mitos registrados na área. (Steinen, ibid.)

Não obstante o que acabamos de dizer, havia, até 1970, pouca informação concernente aos mitos Kamayurá; paradoxalmente, era das tribos a cujo respeito menos se escreveu, recentemente, que mais se sabia quanto à mitologia. Tomando-se a quantidade de mitos e respectivas variantes como índice de nossos conhecimentos sobre a matéria, os índios a ocuparnos apareceriam classificados em terceiro lugar; e isso acentuar-se-ia se, em vez de considerar cada tribo isoladamente, as agrupássemos pela filiação lingüística. Mantendo embora um terceiro lugar, os Tupi viam aumentar ainda, em termos absolutos, a distância a separá-los de seus mais próximos concorrentes, os Karib. Mas a coletânea de Villas Boas (1970) veio alterar a 
situação, diminuindo essa distância e fazendo com que, dentre os grupos tribais, os Kamayurá passassem a ocupar o segundo lugar (v. Quadro 1).

Essa classificação, que se apóia sobre dados quantitativos levantados na bibliografia ${ }^{2}$, tomou em conta não só cada mito, mas todas as suas variantes $^{3}$, e considerou tanto os textos colhidos diretamente de informantes e assim publicados, quanto os resumos feitos pelos diversos autores.

\section{QUADRO 1}

Número de variantes publicadas de mitos e outras narrativas, por classificação lingüística e tribo

\begin{tabular}{|c|c|c|c|}
\hline $\begin{array}{c}\text { Classificação } \\
\text { lingüística }\end{array}$ & Tribos & Total / tribo & $\begin{array}{c}\text { Total } \\
\text { filiação } \\
\text { lingüística }\end{array}$ \\
\hline \multirow{2}{*}{ Aruak } & Waurá & $1($ ?) +59 & 61 \\
& Yawalapití & 1 & \\
& Mehináku & $(?) 1$ & 33 \\
Karib & Bakairi & 25 & \\
& Kalapálo & 4 & 22 \\
Kuikúro & 4 & 6 \\
\hline Tupi & Nahukwá-Matipú & 0 & 132 \\
\hline Isolado & Awetì & 32 & 39 \\
Total anterior & Trumaì & 0 & 171 \\
Total geral & Kamayurá & 132 & \\
\hline
\end{tabular}

Nota: os números referentes às variantes Aruak e assinalados com ponto de interrogação correspondem a um só texto (Ferreira e Ballot 1955), e daí ser 61 e não 62 a soma das variantes.

${ }^{2}$ Aruak: Waurá. Schultz 1965-66. 1966:134-140; Ferreira e Ballot 1955. Yawalapití, Santos 1956:115. Mehináku (?) Ferreira e Ballot 1955.

Karib: Bakairì, Abreu 1938:254-55, 273-74; Steinen 1940:382,477-89, 491,1942:334-37; Oberg 1953:77. Kalapálo, Carvalho 1951:16-25; Cunha 1960: 117-119.

Tupi: Kamayurá, Galvão 1950:335; Oberg 1953:19, 24,30,33,50; Cunha 1960: 120-21; Junqueira 1966:1; Larala 1967:17-19. Villas Boas 1970.

Isolado: Trumaí, Murphy \& Quain 1955:72-76.

3 Consideramos mito a história em si própria, e variantes todas as formas de que se reveste ao ser contada, incluindo as mutiladas ou de qualquer outra maneira abreviadas. 
Nisto, aceitamos a orientação de Lévi-Strauss (1958:232), que considera válidas, para fins interpretativos, todas as versões de um mito. De modo decrescente, dispusemos os troncos e famílias lingüísticos representados no Xingu, de acordo com o número total de narrações deles provenientes; e, dentro de cada um, ordenamos os grupos tribais segundo o mesmo princípio, sintetizando os resultados assim obtidos no Quadro 1. Estes não se podem considerar exaustivos, devido à impossibilidade que houve de acesso a algumas fontes; mas, para o estabelecimento de uma seriação relativa, podem ser considerados satisfatórios ${ }^{4}$.

Nessa seriação vêm em primeiro lugar os Aruak, com o total de 61 variantes de diferentes mitos, 59 das quais se devem ao fecundo labor de Harold Schultz entre os Waurá. Aos Yawalapití cabe apenas uma. A restante é atribuída pelos que a divulgaram (Ferreira e Ballot 1955) aos Waurá e Mehináku, pelo que se poderia talvez creditar uma variante a favor destes últimos. Mas, sendo de segunda mão as informações que conseguiram, e tratando-se de uma reportagem jornalística e não de um estudo antropológico, é cabível manter a respeito algum cuidado.

Seguem-se os Karib, com 33 narrativas. Destas, 25 pertencem ao ciclo de Keri e Kami (Sol e Lua) e demais textos Bakairí trazidos a público por von den Steinen. Quatro são Kalapálo, mas delas apenas uma merece realmente fé; as outras aparecem numa obra (Cunha 1960) que nos deixa em perpétua dúvida quanto à verdadeira origem de seus dados. Mas, como o autor, funcionário do SPI, conviveu algum tempo com os Kalapálo, incluímo-lo, embora cercado da necessária reserva. Dos Kuikúro, tem-se somente as 4 variantes divulgadas pelos Villas Boas, e quanto aos NahukwáMatipú nada nos consta em letra de forma.

Vêm depois os Tupi, com 32 variantes, todas Kamayurá e merecedoras de confiança, porque devidas ou à coleção dos Villas Boas ou às pesquisas de antropólogos profissionais, com uma só exceção (Cunha 1960:120121), como se vê no Quadro 2. Não computamos, entretanto, a única variante. Awetí de que sabemos, pois se acha ainda em vias de publicação em Universitas, revista de cultura da Universidade Federal da Bahia.

Restam, por fim, os Trumaí, aloglotas, com o total de seis variantes, que derivam da primeira investigação efetuada no Xingu com o objetivo de abordar, em profundidade, o estudo de uma sociedade determinada; investigação essa, aliás, em má hora interrompida contra a vontade do

\footnotetext{
${ }^{4}$ Referimo-nos principalmente a notas de campo arquivadas em instituições estrangeiras (p. ex., as de Quain, na Un. de Columbia). Tampouco foi possível consultar os textos publicados por v. den Steinen em Die Bakairi Sprache, Leipzig, 1892.
} 
etnólogo, pouco depois desaparecido. Apesar das dificuldades de comunicação enfrentadas, as excelentes notas de Buell Quain permitiram, postumamente, que Robert Murphy organizasse a monografia onde figuram essas seis variantes 5 .

Em toda a bibliografia consultada, ressalta a importância, no repertório mítico de cada tribo, do ciclo do herói cultural - Mavutsini (n) no caso Kamayurá - e de seus netos, os gêmeos Sol e Lua. Suas origens, aventuras e papel na organização do mundo xinguano são referidos de maneira praticamente idêntica. O mesmo acontece na presente contribuição, completada por outras histórias que reaparecem, mais ou menos sistematicamente, entre as tribos da área. Do total de 39 relatos, 17 têm como personagens centrais aquelas três figura, que comparecem ora juntas, ora Mavutsini(n) ou os gêmeos, isoladamente.

Com estas 39 variantes, que vêm acrescentar às 32 dispersas pela bibliografia, passam os Kamayurá ao primeiro lugar da escala que estabelecemos, com o total de 71 textos. Nem todos são inéditos, como se vê no Quadro 2, onde os reunimos para efeitos de comparação. Além disso, nesta coletânea repetem-se variantes quase idênticas entre si; é que, não obstante essa quase identidade, pequenos pormenores omitidos por uma variante vêm, na seguinte, iluminar aspectos de outro modo obscuros e talvez irrelevantes à primeira vista, mas importantes para a compreensão do mito no decurso de uma análise interpretativa.

Tivemos em mente, antes do mais, facultar documentação para estudo futuro, documentação essa cujo grau de fidedignidade pudesse ser verificado a qualquer momento; e isso marcou os critérios adotados na edição deste material. Implicou semelhante atitude em reduzir quaisquer interpretações - que seriam possíveis - ao mínimo exigido para a compreensão mais imediata do mito, sobretudo ao redigir as notas que se encontram em pé de página. Aliás, nem tudo o que nele se acha pode a rigor ser considerado mito: daí o título que recebeu o trabalho. Mas contos e lendas de fundo mais ou menos histórico importam também para o estudo de uma cultura, pelo que pareceu não só válido mas necessário incluí-los aqui. Por outro lado, o interesse de uma peça de literatura oral indígena não se esgota naquilo que pode revelar sobre a sociedade ou a cultura que a originou. Ela vale por seu próprio caráter de objeto de criação artística.

\footnotetext{
${ }^{5}$ Aludimos às variantes publicadas por outros autores. Utilizamos também, anteriormente, os textos 1,2,3,5,13,16,17,19,24,25 desta edição, como apêndice documental a um trabalho sobre o Kwarip (Agostinho 1966).
} 


\section{QUADRO 2}

Correspondências das variantes Kamayurá publicadas

\begin{tabular}{|c|c|c|c|c|c|c|}
\hline $\begin{array}{l}\text { Ref. das variantes } \\
\text { Tema do mito }\end{array}$ & $\begin{array}{c}\text { N.o nesta } \\
\text { edição }\end{array}$ & $\begin{array}{l}\text { Galvão } \\
1950 \text { p. }\end{array}$ & $\begin{array}{l}\text { Oberg } \\
1953 \text { p. }\end{array}$ & $\begin{array}{l}\text { Junqueira } \\
1965 \text { p. }\end{array}$ & $\begin{array}{l}\text { Laraia } \\
1967 \text { p. }\end{array}$ & $\begin{array}{c}\text { Villas } \\
\text { Boas } \\
1970 \text { p. }\end{array}$ \\
\hline Origem dos rios & 1 & - & 50 & - & $17-19$ & $129-137$ \\
\hline Origem das tribos & 2 & - & 30 & 1 & - & - \\
\hline Origem dos Gêmeos & 1,3 & - & 50 & - & $17-19$ & $57-68$ \\
\hline $1^{\circ}$ Karìp comem. & 5 & - & - & - & - & $57-68$ \\
\hline $1^{\circ}$ Kwarìp falhado & 6 & - & - & - & - & $55-57$ \\
\hline Origem do fogo & 9 & - & 38 & - & - & - \\
\hline Nomin. dos Gêmeos & 10 & - & - & - & - & $57-68$ \\
\hline Origem das relações & $12,13,14$ & - & - & - & - & $129-137$ \\
\hline sexuais e dos rios & & - & & - & - & - \\
\hline Ascensão celeste & 16 & - & - & - & - & $89-95$ \\
\hline Ascensão celeste & 17 & - & - & - & - & $100-115$ \\
\hline Ascensão celeste & 18 & - & - & - & - & $125-129$ \\
\hline Tarefas probatórias* & $19,20,21$ & - & - & - & - & $176-187$ \\
\hline Origem da mandioca & 24 & - & 19 & - & - & - \\
\hline Origem do piqui & 25 & - & - & - & - & $162-166$ \\
\hline Origem do yakui & 26 & - & - & - & - & $99-104$ \\
\hline Origem do yawari & 38 & 355 & - & - & - & - \\
\hline
\end{tabular}

Nota: Figuram aqui apenas os mitos publicados de que há variantes ou fragmentos nesta edição, e que não são todos os divulgados. Relativamente a estes, v. Introdução e fontes aí citadas em rodapé. "Le denicheur d' oiseaux"

\section{OS INFORMANTES}

Por termos empregado mais de um informante, suas diferenças de idade, o grau variável de seus conhecimentos mitológicos, os diversos locais e ambientes das entrevistas, e o maior ou menor domínio - às vezes nulo da língua portuguesa por cada um deles, exigem aqui uma palavra. A idade e os conhecimentos vão desde os de um rapaz que atravessa o período de reclusão pubertária, até ao velho Tawapi, reputadamente o melhor contador de histórias; e os locais, de um gabinete em Brasília, com todos os recursos e conforto, mas um meio estranho para o informante, até ao Posto Leonardo Villas Boas do Parque Nacional do Xingu, e à casa das flautas em Ipavu ${ }^{6}$.

\footnotetext{
${ }^{6}$ Os dados pertinentes aos informantes, intérpretes, grau de fidelidade lingüística (v. adiante), local, data e método de recolha e tradução, relacionados a cada variante de per si (devidamente numera-
} 
Ауири foi o mais novo de todos. Trata-se de um jovem Kamayurá, na época com 17,18 anos, cuja mãe é viúva do antigo "capitão" da tribo. Como esta voltou a casar, com o chefe dos Yawalapití, Ayupu e um irmão mais velho acompanharam-na e residem hoje nesta aldeia. Por parte de pai, é irmão do "capitão" Kamayurá, Takuma(n), a quem já nos referimos quando tratamos da instabilidade do poder entre esses índios, nos anos

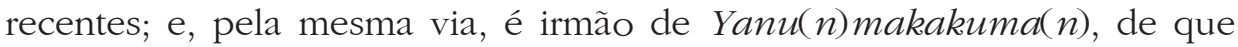
adiante se falará. Devemos-lhe apenas uma variante (n. 21), gravada diretamente em português, língua a cujo uso desde cedo se acostumou, pelo convívio com civilizados. Estava, na ocasião, no Posto Leonardo, em liberdade entre sucessivos estágios de reclusão pubertária, e é significativo que tenha contado precisamente a história do "remédio do urubu,", que se toma durante a iniciação.

Yanu(n)makakuma $(n)^{7}$ fala, como Ayupu, um português bastante fluente, com alguma dificuldade no uso das flexões verbais e nominais, e no estabelecimento das concordâncias na frase. É um informante inteligente e interessado, procurando ser preciso no que diz e tratando, espontaneamente, de esclarecer pontos mais difícies. Nisso muito o ajuda a experiência prévia com antropólogos e lingüistas. Vale a pena notar a sensibilidade que tem para os fatos da própria língua, e o cuidado que põe em assinalar que antigamente - ou pelo menos no "antigamente" dos mitos havia diferenças dialetais entre diversos grupos "Kamayurá". Em fins de 1964, permaneceu por um mês em Brasília, junto aos departamentos de lingüística e antropologia da Universidade; durante esse período, tivemos cerca de uma hora diária de entrevista, e daí vem a maior parte dos textos aqui editados, que foram gravados em português. Mais tarde, pudemos dispor de seu auxílio na tradução de variantes registradas em Kamayurá, no Alto Xingu, mas circunstâncias desfavoráveis impediram-nos de contar com ele, no que aos mitos se refere, durante a maior parte da permanência no campo. Das duas primeiras vezes, achava-se enlutado, e preocupado com a próxima realização do Kwarip de sua mulher; da terceira, havia voltado a casar, agora com uma moça da aldeia de Yawalapití, e residia

da), vão sintetizados no Quadro 3. Os locais são designados P. N. X. (Posto Leonardo Villas Boas do Parque Nacional do Xingu); Ipavu (aldeia Kamayurá); Brasília (Dep. de Antropologia da Universidade).

7 Yanu(n) makakuma(n) aparece na literatura etnográfica como Sapai $(n)$, tal cognome afetuoso parece ter- lhe sido aplicado na infância, por civilizados. Sapai $(n)$ (conforme nos informou) são pigmeus míticos, de uns 4 palmos de altura, negros, antropófagos e de cabelo encarapinhado; vivem em buracos no chão e atacam as pessoas com pequenas bordunas de arremesso. Suas proporções são perfeitas, salvo pela estatura. Consta terem atacado os Trumaí, inclusive na aldeia. 
nela, seguindo a regra de matrilocalidade temporária. Seu interesse pelo sobrenatural e pela mitologia é desusado entre os homens jovens - andará pelos 30 anos -, mas mesmo assim o confronto de suas variantes com as dos homens mais velhos mostra como são mais curtas e menos cuidadas. Aquele seu interesse ligava-se à aspiração de se tornar pajé e adquirir o prestígio correspondente. Quando esteve em Brasília, já passara por uma experiência iniciática, mas faltava-lhe ainda o necessário treinamento formal; em setembro de 1965, ultrapassara essa etapa, e encontrava-se em pleno desempenho de suas funções de xamã.

Tarakway também é pajé, e pouco sabemos de seus dados biográficos. Pertence ao grupo residencial de Takuma(n), e, tendo muito mais idade que Yanu(n)makakuma(n), contará uns 40 a 45 anos. Apesar de pouco ou quase nada falar de português (embora o entenda), é dotado de um caráter jovial que o faz oferecer-se repetidamente para colaborar. Talvez nisso pese muito o fascínio que sobre ele exerce o gravador de som; sempre que se ofereceu, tornou bem claro que era para falar ou tocar flauta, ao microfone. Também pesa a possibilidade de assim obter anzóis e munição. Apenas um mito colhemos dele, mas narrado com um cuidado de artista, saboreando o pormenor, dizendo os diálogos como um ator diria suas falas. A faceta artística de Tarakway revela-se também no gosto pela música, a ponto de o termos encontrado no mato, a caminho do trabalho, tocando flauta e com o facão sob o braço. Das três variantes aqui dadas do mito de Kanaratì e Kanarawarì, a sua é a mais elaborada ( $n$..$^{19}$ ), a que se tem a maior riqueza e complexidade. O registro do original fez-se em fita magnética e foi traduzido por Tuvule, em Ipavu.

O desembaraço desse último no manejo de nossa língua pode comparar-se com vantagem, ao de Ayupu e Yanu(n)makakuma(n), e foi o principal intérprete de que nos valemos. Variadas razões levaram a isso, mas em primeiro lugar esteve seu vivo empenho em aproximar-se dos civilizados e em lhes oferecer esclarecimentos sobre sua cultura. Aliás, mostra-se tão interessado nisto, quanto em aprender dos que vêm de fora de seu mundo. Tem uma inteligência viva, procurando investigar o que não sabe, para depois comunicar os resultados, mas tem também certa tendência a responder apressadamente às perguntas específicas, com prejuízo ocasional para o valor das informações. Sua preocupação com o sobrenatural, a mitologia e o xamanismo é muito inferior à de Yanu(n)makakuma(n); dos cerimoniais, prendem-no mais os aspectos externos, a parte festiva e não a ritual dos mesmos. Mas o que sobretudo o motiva, nas cerimônias intertribais, é o que motiva os homens jovens que, 
como ele, procuram, nas danças e principalmente na luta corporal, brilhar e adquirir o prestígio que envolve os "campeões". Não nos ficou completamente claro, no entanto, o porquê do seu comportamento para com os civilizados. Por um lado, é patente uma genuína vontade pessoal de agradar, e a capacidade de compreender que se tenha interesse por seus costumes, como o tem pelos nossos. Mas, por outro, é inegável que há nele uma busca de se valorizar, pela associação e até exterior identificação ${ }^{8}$ com representantes de uma sociedade e de uma cultura que aparecem, a seus olhos, mais ricas e poderosas. E usa isso conscientemente, com o fito de ganhar a influência política na aldeia, que nem seu status nem sua idade - à roda dos 27 anos - de outro modo lhe facultariam. É ele que se tem apresentado como rival de Takuma( $n$ ) na chefia do grupo, conseguindo, inclusive, afastá-lo dela por algum tempo.

Awmari figura nesta coleção com a menor das contribuições. Aliás, essa intervenção deve-se quase à obra do acaso: foi preciso interromper, por motivos involuntários, a gravação do mito do jogo de bola feito por Tawapi, sem que fosse possível retomá-la. Para que o texto não ficasse truncado, Tuvule conseguiu a colaboração de Awmari. Este tomou a narrativa no ponto onde se interrompera depois de ter ouvido atentamente o trecho gravado, tendo sido ele a optar por essa solução. É o que entre os Kamayurá se pode chamar velho, tendo talvez de 55 a 60 anos, e sendo incapaz de estabelecer comunicação em português.

De todos os informantes, o mais qualificado é, sem dúvida Tawapi. Era, em 1965, um dos mais idosos da tribo, rondando provavelmente a casa dos 70 anos, e faleceu em começos de 1969. Seguindo nisso uma regra aplicável a todos os velhos Kamayurá, não tinha meios de se exprimir em português, embora entendesse alguma coisa. Reconheciam-no unanimemente como o "velho" ( mira), e o contador de histórias por excelência. Não se tratava a rigor de um especialista, mas é segura a evidência de que seus conhecimentos lhe chegaram através do pai, e tendem a permanecer na mesma família, transmitindo-se patrilinearmente. Seu filho, de uns 40 ou mais anos, há muito se iniciara nesse aprendizado, e é hoje indicado como o mais sabedor do assunto. É de notar que o processo de aquisição do repertório começa cedo, prolongando-se durante a vida toda.

\footnotetext{
${ }^{8}$ Manifesta no uso de pinturas corporais não tradicionais: barba e bigode pintados a carvão; pintura de cabeça formada por uma calota branca de tabatinga com um traço horizontal envolvendo-a por trás e pelos lados e interrompida na frente, imitando capacete militar, em vez da pasta vermelha de urucu normalmente empregada; o traço envolvente era preto. Aprendeu, também e com facilidade, a manejar um gravador e a tirar fotografias. Tuvule faleceu devido a seqüelas de malária crônica, antes do primeiro semestre de 1973.
} 


\begin{tabular}{|c|c|c|c|c|c|c|c|c|c|c|c|c|c|c|c|c|c|c|c|c|c|c|c|}
\hline \multirow[b]{2}{*}{ 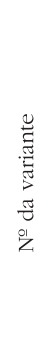 } & \multicolumn{5}{|c|}{ Informantes } & \multicolumn{2}{|c|}{ Intérpretes } & \multicolumn{6}{|c|}{ Local } & \multicolumn{2}{|c|}{ Língua } & \multicolumn{4}{|c|}{$\begin{array}{l}\text { Método de } \\
\text { recolha }\end{array}$} & \multicolumn{3}{|c|}{ Datas } & \multirow[b]{2}{*}{ 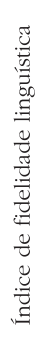 } \\
\hline & 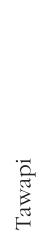 & 氶 & 政 & 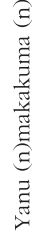 & 売 & 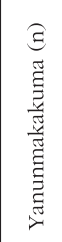 & 曾 & 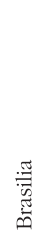 & 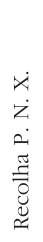 & 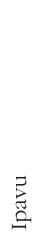 & 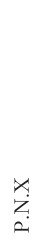 & 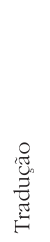 & $\begin{array}{l}\text { 胥 } \\
\text { : }\end{array}$ & & $\begin{array}{l}0 \\
0 \\
0 \\
E \\
0 \\
0 \\
0\end{array}$ & 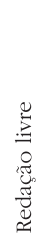 & & 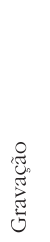 & 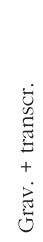 & & $\stackrel{\sim}{\precsim}$ & ڤ & \\
\hline 01 & + & - & - & - & - & + & - & - & - & + & - & - & + & + & & - & - & - & + & - & - & & \\
\hline 02 & & - & - & + & - & - & - & & - & - & - & - & - & - & + & - & + & - & - & + & - & - & 3 \\
\hline 03 & & - & - & - & - & + & - & + & - & + & + & - & - & & - & - & - & - & + & - & & - & 2 \\
\hline 04 & & - & - & + & - & - & - & & - & - & - & - & - & - & + & & - & + & - & & - & - & \\
\hline 05 & + & - & - & - & - & - & + & - & - & + & - & - & + & + & - & - & - & - & + & - & - & + & 2 \\
\hline 06 & & - & - & + & - & - & - & & - & - & - & - & - & - & t & + & - & - & - & & - & - & \\
\hline 07 & & - & - & + & - & - & - & & - & - & - & - & - & - & + & - & + & - & 二 & + & - & - & 3 \\
\hline & & - & - & + & - & & _ & & - & - & - & - & - & - & + & - & - & + & - & & - & - & \\
\hline 10 & - & - & - & + & - & - & - & & - & - & - & - & - & - & + & - & - & + & - & + & - & - & \\
\hline & - & - & - & + & - & - & - & & - & - & - & - & - & - & + & - & + & - & - & + & - & - & 3 \\
\hline 12 & - & - & - & + & - & - & - & - & - & + & - & - & - & - & + & + & - & - & - & - & - & + & 4 \\
\hline 13 & & - & - & - & - & - & + & - & - & + & - & - & + & + & - & - & - & - & + & - & - & + & \\
\hline 14 & - & - & - & + & - & - & - & & - & - & - & - & - & - & + & - & + & - & - & + & - & - & \\
\hline 15 & - & - & - & + & - & - & - & & - & - & - & - & - & - & + & - & + & - & - & + & - & - & \\
\hline 16 & & - & - & - & - & - & + & - & - & + & - & - & + & + & - & - & - & - & + & - & - & + & \\
\hline 17 & - & - & - & + & - & - & - & & - & - & - & - & - & - & + & - & + & - & - & + & & - & \\
\hline & & - & - & + & - & & - & & - & - & - & - & - & & & - & + & - & - & + & - & & \\
\hline 19 & - & - & + & - & - & - & + & - & - & + & - & - & + & - & - & - & - & - & + & - & - & + & \\
\hline 20 & - & - & - & + & - & & - & & - & - & - & - & - & - & + & - & - & + & - & + & & - & \\
\hline & & - & - & - & + & & & & + & - & - & - & - & & & - & - & + & - & - & & + & \\
\hline 22 & - & - & - & + & - & - & - & & - & - & - & - & - & - & + & - & - & + & - & + & - & - & 1 \\
\hline 23 & & - & - & + & - & & - & & - & - & - & - & - & - & + & - & - & + & - & + & & - & \\
\hline & & - & - & + & - & & & & - & - & - & - & - & - & + & - & + & - & - & + & - & - & \\
\hline 25 & - & - & - & + & - & - & - & & - & - & - & - & - & - & + & - & + & - & - & + & - & - & 3 \\
\hline 26 & - & - & - & + & - & & - & & - & - & - & - & - & - & + & - & - & + & - & + & & - & \\
\hline 27 & & - & - & + & - & & & & - & - & - & - & - & - & + & - & - & + & - & + & - & & \\
\hline & & - & - & + & - & & - & & - & - & - & - & - & & & - & - & + & - & + & & - & \\
\hline 29 & - & - & - & + & - & - & - & & - & - & - & - & - & - & + & - & + & - & - & + & - & - & \\
\hline 30 & & - & - & + & - & & & & - & - & - & - & - & - & + & - & + & - & - & + & - & & \\
\hline & & - & - & + & - & - & & & - & - & - & - & & & & - & - & + & - & + & & - & \\
\hline 32 & & - & - & + & - & & & & - & - & - & - & - & & + & - & - & + & - & + & & & 1 \\
\hline 33 & & - & - & + & & & & & - & - & & - & & & & - & - & + & - & + & & & \\
\hline & & - & - & + & - & - & & & - & - & - & - & - & - & + & - & - & + & - & + & - & & \\
\hline 35 & & - & - & + & - & - & - & & - & - & - & - & - & - & + & - & - & + & - & + & - & & 1 \\
\hline 36 & & - & - & + & - & & & & - & - & - & - & - & - & + & - & - & + & - & + & - & & \\
\hline 37 & & - & - & + & - & - & - & & - & - & - & - & - & - & + & - & - & + & - & + & - & - & \\
\hline & & & - & + & & - & & & & & - & - & 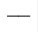 & & + & - & + & - & & + & & & \\
\hline 39 & + & + & - & - & - & - & + & - & - & + & - & - & + & + & - & & - & - & + & - & - & + & \\
\hline otal & 6 & 1 & 1 & 31 & 1 & 1 & 6 & 30 & 1 & 8 & 1 & 6 & & 7 & 32 & 2 & 12 & 18 & 7 & 30 & 1 & 8 & \\
\hline
\end{tabular}

Hwahu já iniciou a educação de seu filho Karu (em reclusão pubertária em 1969), e espera-se que este, chegada sua vez, passe adiante a tradição. Sendo Tawapì o melhor narrador e sendo ele a saber maior número de mitos, há de parecer estranho que, numa coletânea como a presente, só figurem seis variantes a ele devidas.

Isto adveio, em parte, de circunstâncias do momento, em parte, do próprio caráter de Tawapi, que nem sempre se encontrava disposto a trabalhar como informante, fazendo por vezes passar bastante tempo antes 
de se resolver a contar alguns mitos. A importância que lhes atribuía revelava-se no tipo de retribuição econômica por ele pedida. Toda a prestação de serviços assenta, no Xingu, num princípio de reciprocidade, que implica sempre numa contraprestação; isto estende-se às atividades cerimoniais e às práticas xamânicas, mas é nestas que os "preços" mais elevados se verificam, refletindo a alta conta em que são tidas as funções do pajé. Também no tipo de presentes que Tawapi procurava obter do etnólogo interessado em suas histórias, transparece o valor que lhes dava e o grau de respeito esperado, para si e para seus conhecimentos. As solicitações eram específicas e atingiam objetos dos mais cobiçados na área, alguns mesmo difíceis de obter.

Por causa de sua maneira de ser e de seu comportamento no caso específico, optamos por gravar seguidamente os mitos, sempre que lhe encontrávamos disposição, visando ganhar tempo, e precisão nos textos. Obviamente, isto fez-se sempre em Kamayurá. Assim, ficava livre do moroso processo de tradução intercalada, e de interromper a narrativa. A seguir, o ditado era repassado com um intérprete (num caso Yanu(n)makakuma(n), nos outros Tuvule), repetindo, quando necessário, as passagens de maior dificuldade; a verificação a que foram submetidos os frutos desse método, comparando-os com variantes dos mesmos mitos, Kamayurá ou não, indica que é tão satisfatório quanto o podem ser os que implicam no uso de intérpretes.

Apesar disso, os resultados foram bastante parcos, se se considerar a questão apenas no âmbito desta edição. Mas colher material para ela não foi o principal objetivo do trabalho de campo, e sim submeter a descrição e análise acuradas a festa do Kwarip. Os mitos que contou Tawapi ligam-se, de uma forma ou de outra, a esse ciclo cerimonial. De modo que a publicação do conjunto de mitos Kamayurá que recolhemos até a data é, de certo modo, subsidiária àquela análise, que concentrou o melhor da atenção e esforço. Aliás, nas primeiras fases da pesquisa de campo, Tawapi estava por inteiro absorvido na orientação do ritual, e sem tempo de se dedicar a outras coisas, em setembro de 1965. Assim, só em setembro-outubro de 1966 foi possível combinar ao estudo do Kwarip o da mitologia.

Tawapi merece, ainda, um derradeiro reparo. Por melhor que seja o intérprete, ou mesmo que sabendo-lhe a língua pudéssemos penetrar todas as nuances de suas histórias, um aspecto destas será sempre impossível reproduzir. E este é o do gesto aliado à palavra, das entonações da voz, da mímica sóbria mas plena de significado de que se acompanhava, do talento dramático pelo contar do mito revelado. Para além do significado das palavras, sente-se e fica-se preso pelo tom quase onomatopaico de certas 
frases, pelo choro discreto e magoado dos Gêmeos que perdem a mãe; e havia um humor malicioso a brilhar-lhe nos olhos, nalguma passagem mais picante. Nisso, Tawapí era difícil de igualar. Ao desaparecer, levou consigo muito do que não chegou a transmitir a seu filho, nem aos outros contadores da aldeia.

\section{MÉTODOS DE CAMPO E CRITÉRIOS DA EDIÇÃO}

Mostrou-se eficaz o processo seguido nas entrevistas com Tawapi, que foi adotado sempre que um tradutor se impunha. Mas, apesar de ser o melhor que encontramos, por não interromper a narrativa a cada instante, levantou alguns problemas.

Primeiro deles, a tendência generalizada, e forçosa de aceitar, que têm os informantes no sentido de dar não uma versão ao pé da letra, mas uma em que o texto se simplifica, saltando trechos muito repetidos, sintetizando os diálogos numa exposição sucinta de seu conteúdo. Pode-se avaliar isto bem, comparando uma variante cujo original foi Kamayurá, com outra cuja gravação se fez em português: salta logo à vista o estilo vivo, expressivo e dialogado desta, contrastando com a prosa corrida daquela. Como exemplo, bastará tomar as três variantes do mito de Kamaratì e Kamarawari (n. ․ S 19, 20, 21). Se a traduzida é rica em acontecimentos e episódios, as duas outras levam-lhe a palma no vigor estilístico. E, diga-se de passagem, neste aspecto estão muito mais próximas de como as contariam na língua indígena, não obstante serem bastante abreviadas quanto ao enredo propriamente dito. Tal coisa é de atribuir à idade dos informantes. Tivessem eles a experiência e memória dos mais velhos, ou fossem estes capazes de se comunicar em nosso idioma, mais próximo se estaria do original, na forma e no conteúdo.

No citado processo de gravação, houve a impossibilidade de utilizar dois aparelhos; assim, o intérprete ouvia o gravador por um tempo, parava, e ditava a seguir sua tradução, passada então ao caderno de campo; depois, repetia a operação enquanto necessário. Como nos interessava a história em si, e não reproduzir, palavra a palavra, a fala do tradutor, surgiu o segundo problema, e surgiu como de ordem lingüística. O padrão do português do indígena é condicionado pela estrutura de sua língua nativa e pela da dos homens civilizados como os quais mantém habitualmente contato, e isto o afasta consideravelmente do nosso. Suas características mais notáveis - dificuldade com as flexões verbais e nominais - foram assinaladas quando falamos de $\operatorname{Yanu}(n)$ makakuma(n). O léxico é repeti- 
damente atingido, coisa para a qual deve o leitor estar atento, evitando ser induzido em erro; um dos casos mais comuns é o do sistemático emprego do verbo procurar em vez de perguntar. Mas há outros, nem sempre fáceis de identificar, o que caberá às notas de que adiante nos ocuparemos.

Preocupados, como dissemos, com o mito e não com os aspectos formais do português do índio, houve, ao escrever as traduções, uma inevitável e mesmo inconsciente "re-padronização" dele em termos de nosso próprio padrão, que se faz sentir sobretudo no uso dos pronomes complemento. Poder-se-ia, mesmo, falar de um fenômeno de interferência lingüística. Seria de objetar que, conscientes dele, deveríamos expurgar o texto de suas conseqüências; mais isto implicaria em maiores modificações, sempre passíveis de inexatidão. Por isso preferimos ficar nesta advertência.

O mesmo se deu, em tão grande ou talvez maior escala, nos casos em que, sendo o mito narrado em português, faltou um gravador magnético: então, o registro fez-se logo por escrito. No quadro 3, que apresenta os dados essenciais sobre as condições de recolha de cada variante, estes dois métodos aparecem, respectivamente, sob as rubricas "gravação + transcrição”. Recorremos ainda a um outro processo, quando a situação impediu gravar ou transcrever de imediato. Na primeira oportunidade, a redação foi feita de memória, e só se atendo ao conteúdo da história; razão pela qual não se esboçou, sequer, o problema atrás abordado. Designamo-lo, no quadro 3, como "redação livre", e seu uso restringiu-se a apenas duas variantes, e a estas mesmo por ter sido inevitável. Deve ficar claro ser impreciso e só justificado por condições externas particulares.

Tornaram-se necessárias as observações anteriores, por ter dominado em nosso trabalho um outro método, mais fiel para com o português do informante. Gravando nesta língua, e sendo ela a única em jogo, as entrevistas não tiveram o prejuízo, parcial embora, da intervenção de terceiro. As narrativas só mais tarde, em gabinete, foram postas por escrito. Ao todo, isto deu-se com 18 dos textos, um devido a Ayupu, os outros a $\operatorname{Yanu}(n)$ makakuma(n), os quais deram entrada no Quadro 3 sob o título "gravação".

Face ao material bruto assim alcançado, elaboramos critérios editoriais que lhe dessem unidade e que salvaguardassem o valor individual das variantes enquanto documentos de ordem etnográfica e lingüística; lingüística também, porque, do ponto de vista léxico, sintático e estilístico, os textos obtidos pelo quarto dos métodos descritos documentam o jogo das forças aculturativas em ação. Nem sempre, entretanto, aquele valor corre paralelo com a facilidade de compreensão da narrativa, pelo que se tornaram necessárias algumas intervenções. 
Atribuímos a cada processo de recolha, de acordo com o grau estimado de "re-padronização" que implicou, um índice (de 1 a 4 inclusive), indicando da fidelidade a esperar, dele, em relação à língua portuguesa do informante ou do tradutor. O índice 1 corresponde à "gravação" e a uma fidelidade absoluta, pois as intervenções propositais vão devidamente identificadas. Seguem-se os índices 2 ("gravação+transcrição") e 3 ("transcrição"), numa escala crescente de distanciamento do padrão original. Por fim, e já totalmente desligado deste quanto à forma, vem o índice 4, correspondente à "redação livre".

Quaisquer que fossem os índices correspondentes a cada variante (v. Quadro 3), os critérios de fixação do texto definitivo mantiveram-se os mesmos. Nunca conseguimos o que com justiça se possa chamar titulo de um mito: o que ocorre é uma indicação sucinta e variável de seu conteúdo, ou então o nome do personagem ou personagens centrais, ou a alternância de ambas as coisas. É, por exemplo, o que acontece com o mito de "Kamarati e Kanarawari" (variantes n. $\stackrel{2}{21}$ ). Diante disso, e da particularidade destacada pelo índio para designar o mito, é que o intitulamos de modo que, se não é arbitrário, tampouco corresponde a uma realidade concreta. No corpo das variantes, a imprecisão ocasional das expressões, a omissão de palavras ou mesmo sua troca ou colocação deslocada, obrigaram freqüentemente a introduzir esclarecimentos, correções, palavras ou parte delas, com o objetivo de tornar coerente e compreensível o relato. Isso, sempre que feito, indicou-se por colchetes e reduziu-se ao mínimo indispensável; se uma forma errada não deturpava o sentido da frase e o obstáculo era fácil de superar, deixamos a forma intocada. As observações paralelas à narrativa, oriundas do informante ou do interprete, figuram entre parênteses, e, quando vieram deste ultimo, isso foi apontado entre colchetes. A pontuação cingiu-se às pausas do original, tanto quanto viável, e a divisão em parágrafos obedeceu ao que parecia exigir o desdobrar-se do assunto.

Impossível de indicar nos textos, mas para o qual se deve aqui chamar a atenção, é um fato ligado aos meios de enfatização e exemplificação verificados nos mitos. Quando se quer sublinhar um acontecimento, ou apresentar sobre ele maior soma de pormenor, é repetido uma, duas, três ou mais vezes, mostrando a cada vez uma nova faceta. Precisa-se cuidado constante, para não confundir esse recurso estilístico, com a repetição sucessiva de eventos míticos semelhantes entre si numa mesma variante, o que também não é raro. Isso é fácil ao envolver apenas frases curtas, mas não o é tanto quando se trata de períodos maiores. 
Para as palavras indígenas, houve dois critérios. Na grafia dos nomes de tribos, atuais ou extintas, seguimos o estabelecido pela 1. ${ }^{a}$ Reunião Brasileira de Antropologia, com pequena alteração: damos Awetì, Kuikúro e Yawalapití, e não Awetí, Kuikutl e Yawarapití, por serem aquelas as pronúncias ouvidas aos Kamayurá e abonadas por outros autores ${ }^{9}$. Já na grafia da língua destes últimos (em itálico), recorremos a um compromisso entre os sistemas de transcrição fonética e fonêmica, adaptado aos recursos tipográficos disponíveis e atendendo ao objetivo de facilitar a leitura ao não-especialista ${ }^{10}$. Os valores fonéticos dos sinais usados descrevem-se na lista abaixo.

\section{CONSOANTES \\ P - oclusiva bilabial surda \\ $\mathrm{t}$ - oclusiva alveolar surda \\ $\mathrm{k}$ - oclusiva velar surda / oclusiva glotal \\ ts - africada alveolar surda \\ $\mathrm{n}$ - nasal labial sonora}

\section{SEMICONSOANTES}

$\mathrm{Y}$ - alta anterior fechada, não arredondada

\section{VOGAIS}

i - alta anterior fechada, não arredondada

ì - alta central fechada, não arredondada

$\mathrm{u}$ - alta posterior fechada, arredondada

\section{SINAIS DIACRÍTICOS}

(n) - nasalização

\section{ACENTUAÇÃO}

O acento tônico, não fonêmico, recai sempre na última sílaba.

\author{
ny - nasal palatalizada sonora \\ ng - nasal velar sonora \\ r - "flap" alveolar sonoro \\ 1 - lateral alveolar sonora \\ $\mathrm{v}$ - fricativa lábio-dental sonora, branda \\ h - fricativa glotal surda
}

w - alta posterior fechada,
arredondada

e - média anterior fechada, não arredondada

o - média anterior fechada, arredondada

a - baixa central aberta, não arredondada

\footnotetext{
${ }^{9}$ Kuikurus (Carneiro e Dole 1956-7). Kuikúro, Yawalapití, Awettí (Galvão e Simões 1964:141). Estes últimos grafam Nahuquá-Matipúhy, para a aldeia oriunda da fusão desses dois grupos; as resoluções da 1. Reunião Brasileira de Antropologia dão Nahukuá e omitem Matipúhy; adotamos NahukwáMatipú.

${ }^{10}$ Usamos o mesmo sistema anteriormente, tomando como base das decisões o vocabulário padrão do Kamayurá de Carl Howard Harrison (s/d).
} 
Para tornar suficientemente claras certas passagens, em especial as alusivas a particularidades técnicas ou da vida diária da aldeia, muitas vezes os critérios seguidos e as intervenções realizadas deixam, ainda, a desejar. Foi assim incluído um corpo de nota, que aborda as dificuldades à medida que surgem. Obedecendo ao caráter documental prevalecente no trabalho, essas notas prendem-se, antes, aos aspectos culturais mais imediatos do mito que à procura de uma interpretação mais ou menos especulativa, mais ou menos analítica. Quando, para melhor compreender a ação mítica, foi forçoso interpretar, isso fez-se, e só, nos estreitos limites do necessário. Na verdade, só cremos num real valor da interpretação quando se possa considerar o mito não isolado, mas referido a seu contexto, natural, social e cultural, e, deste, especificamente ao ritual que o complementa. Aqui, isso só seria praticável com os mitos associados ao ciclo do Kwarip, coisa a que nos dedicamos noutro lugar; quanto aos demais, julgamos ainda pouco abundantes os dados de campo, para que nos abalancemos à tarefa.

Foi também essa uma das razões para não optarmos por uma classificação tipológica na ordenação da seqüência de mitos, classificação que se basearia em suas características internas. Nem tal ordenação se apoiou, por outro lado, numa cronologia das ações narradas, que, se pode estabelecer nuns casos, não se pode em outros. Pouca, ou melhor, nenhuma evidência interna ou externa descobrimos que pudesse relacionar cronologicamente todos os acontecimentos míticos. Um caminho existe que permitirá avançar, até certo ponte, nesse sentido, e será o de tentar correlacionar os mitos com a posição ocupada, nos ciclos vital e anual, pelos rituais a que possam estar ligados.

Preferimos, portanto, seriá-los de modo a que se expliquem mutuamente, através de personagens ou acontecimentos tornados em traço de união, em fio condutor a ser acompanhado durante a leitura. Daí resultou, inevitavelmente, certa classificação, ou ao menos certo agrupamento em torno de temas centrais ou de personagens. Um esquema classificatório rigoroso, indispensável como projeto futuro, virá quando novos textos se juntarem a estes, e, com eles e outros elementos, for mais ampla e estruturada nossa visão do mundo religioso Kamayurá.

Encerra o volume um índice de personagens e lugares míticos, situados por variante, e não por página, pensado e organizado para permitir avaliar, sem perda de tempo, seu papel, caráter e significado na mitologia apresentada.

Brasília, 1970.

P.A. 
Parte II

MITOS E OUTRAS

NARRATIVAS KAMAYURA 


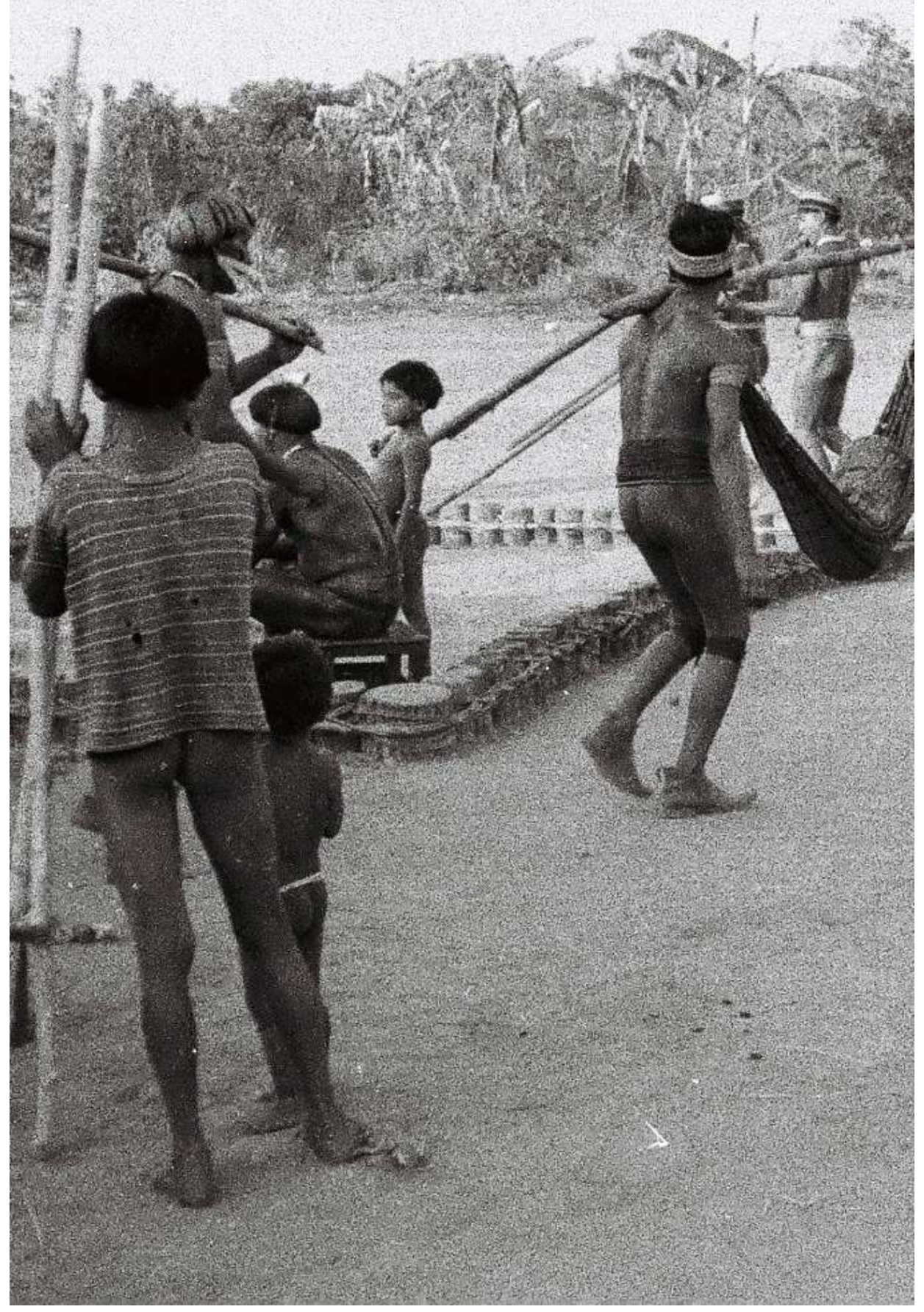




\section{1- ORIGEM DE KWAT E YAİ}

Mavutsini $(n)^{1}$ pegou flecha, para a gente, para os Kuikúro, para os Kalapálo arco de pindaíba, para os Waurá pegou rede, ele entregou rede para os Waurá. Para a gente entregou flecha, İwirapitang. Para os Kuikúro arco de pindaíba, para os Kalapálo também².

De manhã Mavutsin( $n$ ) levantou-se e disse: "Minha filha, vou apanhar corda de arco". "Tenha cuidado, senão seu sobrinho [filho da irmã] vai matar você." Aí ele disse: "Não, não pode matar." Aí ele foi, foi apanhar corda de arco, foi lá perto da casa de Yawat [onça], apanhar embira de tucum e disse: "Quem está tirando corda de arco? Não, não pode. Vamos cercar Mavutsini(n), vamos matar". E as onças saíram de casa. Yawat era sobrinho de Mavutsini $(n)^{3}$.

\footnotetext{
${ }^{1}$ Galvão (1950:355) grafa Mavutxinín; Oberg (1953:30), Mavutsiné; Junqueira (1966:1), Mavutsini(n); Laraia (1967:-17-19) dá Moãcini(n). Este último caso tem interesse, pois mua(n)ng significa feitiço ou remédio, e parece ser também o nome de determinada madeira usada em práticas mágicas. Por outro lado, a mavu (outra madeira) aludem os cantos do Kwarìp como uma das que se valeu Mavutsini(n) para fazer os Kwarìp, isto é, as efígies que se transformaram em mulheres; mas outros informes dizem que se fala dela nos cantos apenas porque a seiva de mavu serviu para pintar os troncos. Além desta aproximação, nada nos é possível agora acrescentar, que possa esclarecer possível relação.

${ }^{2}$ Esquematicamente, trata-se aqui da especialização manufatureira intertribal e da origem dos grupos xinguanos. V. os mitos 2 e 36, e também Junqueira 1966:1, Oberg 1953:30. Íwirapapita (n)ng, "arco preto".

${ }^{3}$ Filho da irmã (não se esclarece se biológica ou classificatória), de Mavutsini( $n$ ) (que aliás em mito algum aparece realmente tendo uma irmã, antes, pelo contrário, surge como o ser primordial), Yawat situa-se em relação a ele de forma ideal e coerente com o desenrolar do mito. Ao oferecer-lhe suas filhas em casamento, Mavutsíni(n) segue as regras de casamento preferencial entre primos cruzados. Repare-se também que se trata de um caso de poliginia sororal, como é frequente entre os xinguanos.
} 
Quando o Yawat, esticou o arco, Mavutsini( $n$ ) falou: "Não faça isso com seu tio não, eu tenho moças para você casar." Aí o outro companheiro da onça perguntou: "Quero ver onde foi, quero matar bem no pé do ouvido dele." "Não, não pode" [disseram-lhe]. Um dizia que estava querendo matar, mas o outro dizia não estava querendo matar.

Aí Mavutsini $(n)$ voltou para a casa dele, levando Yawat com ele, o que tinha avisado que o outro queria matar Mavutsini(n). Chegaram em casa, ele mostrou o rapaz e disse que vinha para casar.

Aí as moças disseram que não queriam casar, porque a mãe dele, Yawat, as ia comer. Mavutsini $(n)$ foi perguntando e nenhuma das moças quis.

Chegou, ai começou a fazer gente, aí começou gente mesmo, começou Caraíba, começou Kalapálo. Ele cortou Kwarip, primeiro [de] Kamiuwa, depois de outro pau que se chama Kwarip mesmo, dois Kwarip e um Kamiuwa. Começou a trabalhar de manhã, fez barbante, fez cabelo, braço, o pé não porque não tinha jeito mesmo. Fez olhos com umas baguinhas vermelhas (que têm um pontinho preto). Então quis fazer dentes, com concha de raspar mandioca, 'ita $(n)$, quebrada. Mas, quando experimentou risada, não foi boa, era preta. Aí chamou Kakatsi, que ajudou; chegou na casa dele, pediu para vir ver e ajudar, porque não tinha dado conta de acabar tudo. "O que é que não está certo?" "É o dente". Chegaram lá, pegaram caroço de mangaba e colocaram no Kwarip ${ }^{4}$; estavam fazendo gente. Aí Kakatsi disse: "Agora está pronto."

[Mavutsini( $n$ ) mandou as mulheres feitas assim, para casarem com a onça; mas uma delas atrasou-se].

A mulher que ficou [perdida] virou bicho, com cabelo grande igual ao de mulher. Tem quem já viu, grita igual mulher, ainda hoje tem gente que vê.

As outras mulheres foram adiante, chegaram na aldeia da onça eram quase três horas [da tarde - o inf. Aponta a altura do sol], chegaram no porto da onça: "Vamos trepar no pau, vamos ficar esperando gente." Aí ficaram esperando, e apareceu $\operatorname{Nyau}(n) n y a k u n y a(n)$, anu preto, era mulher. Veio, tomou banho e disse: "Não sou preta assim não, sou branca." Aí olhou para cima e viu as mulheres: "Que é que vocês estão fazendo aì?" "Estamos esperando o pessoal."

\footnotetext{
${ }^{4}$ Kwaīp significa duas coisas: os paus de que foram feitas as mulheres, e os que, semellhantes a esses, se erguem na festa dedicada aos mortos; e a própria festa, realizada periodicamente pelos fins da estação, o nome Kwarip parece ter-se alargado, de designativo apenas dos paus, para designativo da festa, por interferência do elemento civilizado na área. Obtivemos o informe taxativo de que o nome antigo da festa era Torip. Mas hoje Kwaripé termo corrente na área e fora dela, usado inclusive pelos índios de outras tribos, nas quais a festa tem denominação específica. Por isso usaremos Kwarip e não Torìp neste trabalho.
} 
Aí a turma de Yawat estava jogando bola ${ }^{5}$, e a anu foi lá e avisou que as mulheres estavam lá. Aí ele foi [Yawat], jogou flecha de assobio, depois outra, perto do porto, que caiu perto das mulheres, mas nenhuma quis pegar a flecha. Então o que tinha jogado achou que elas não eram parentes dele. Apanhou a flecha e foi embora. "Devem ir para casa de outro, porque não apanharam minha flecha. Se tivessem apanhado, então era comigo." E foi embora. Voltou lá para diante.

Aí Awaratsi(n)ng,irmão da onça, jogou flecha, e elas apanharam, as três mulheres. Aí Awaratsi( $n$ )ng levou-as para a casa dele; estava cheia de minata, que servia para mingau, cheio de caroços, e as mulheres não beberam, por isso. Quem tinha feito era a mulher de Awaratsi(n)ng. Passaram dois dias, aí a mãe de Yawat estava socando mandioca, e a mãe de Awaratsi(n)ng mandou as moças pedirem massa para comer.

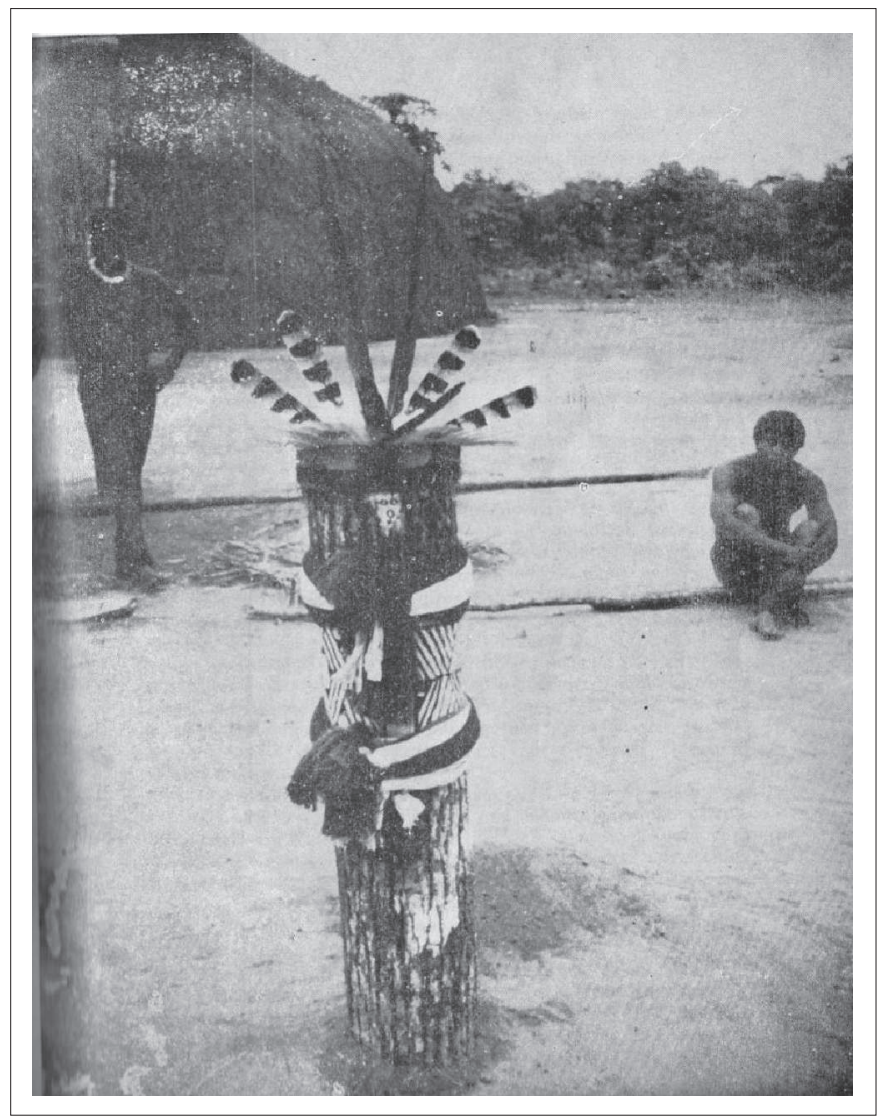

Estampa 1 - Kwarìp

${ }^{5}$ Sobre o jogo de bola, v. o mito 39. 
A Mãe da Onça perguntou para elas que é que estavam querendo, e disse que ia dar. E disse que Awaratsi( $n)$ ng só comia minata, mandioca não. Aí convidaram as mulheres a trabalhar, a fazer beiju para a mãe de Yawat. As onças comiam só caça, resolveram e caçar veado para comer. E pediram às mulheres para fazer mingau, beiju: "Vocês querem ajudar hoje, porque eles vão caçar e têm de levar beiju para comer?"

Aí chegaram da caça, Awaratsi(n)ng também tinha ido com Yawat. Trouxeram muito veado e assaram muito para comer, e trouxeram pedaços para as mulheres. Aí essas moças estavam trabalhando para a onça, na casa dele. Então a mãe de Awaratsi( $n) n g$ chamou-as para comer, e elas disseram que iam acabar de fazer o que estavam fazendo, depois voltavam. Deram pedaços de beiju para Awaratsi( $n$ )ng comer carne assada. Depois, Awaratsi( $n) n g$ convidou-as para voltar a sua casa; mas elas não quiseram, lá só havia minata. Aí fizeram mingau de caroço de piqui e deram para a mãe de Awaratsi(n)ng, e o espinho [ do piqui] espinhou a garganta dela, toda, não podia mais falar: "Agora, você vai lá para a estrada e você tira." Ela foi, roncando. "Você pode ir assim toda a vida. Pode ir mais longe." Assim a mãe de Awaratsi( $n) n g$ ficou como é hoje. Aí Awaratsi( $n) n g$ veio, voltou a convidar para comer. Elas deram beiju para ele. Disseram que iam daí a pouco. Fizeram mais mingau de piqui e Awaratsi( $n) n g$ ficou igual à mãe; foi para a estrada, foi longe fazendo força, mas não conseguiu tirar o espinho de piqui, foi embora e ficou assim roncando, até hoje, lá no mato.

Aí essas mulheres ficaram morando na casa de Yawat, porque o Awaratsi(n)ng já tinha ido embora. Aí convidaram para ir para a roça. Chegaram no meio da estrada e Yawat falou: "Se minha mãe convidar vocês para catar piolho quando eu não estou, não vão não que ela come vocês. Ela vai dizer assim: "Estou cheia de piolho; não vou fazer nada, pode vir catar..." Aí as mulheres ficaram sabendo: "Mas não catem não, senão ela come vocês." 6

Então a mãe da onça coçou a cabeça, pedindo para catar piolho. Uma moça foi, começou a catar e a comer o piolho. Mas o cabelo enrolou no piolho e no dente da moça; ela cuspiu e a mãe da onça disse: "Você está com nojo de mim", e pulou nela, sangrou ela no pescoço. A moça estava meio prenhe e morreu, morta pela mãe da Onça.

\footnotetext{
${ }^{6}$ A proibição de Yawat conforma-se à norma de relações de evitação entre sobra e nora. Vê-se como aquela é potencialmente perigosa a esta; o que também explica a recusa inicial das filhas de Mavutsíni( $n$ ) quanto ao casamento com Yawat.
} 
Quando chegaram da roça, viram que a mais nova estava morta. A mais velha disse que devia ser a mãe da Onça que tinha matado. Disse isso para Yawat, que era marido dela, e disse: "Agora você vai convidar meu avô, Tanaba(n) [formiga], para tirar a criança da barriga dela." Tanaba( $n)$ veio, chegou lá perto da mulher que estava morta, examinou. E disse: "É homem, não é mulher não [que ela tinha no ventre]." E tirou o menino; depois voltou a dizer a mesma coisa e tirou outro. Guardaram-nos num quartinho ${ }^{7}$ e de manhã os meninos já estavam mexendo. O pai botou na porta deles a rodilha de transportar cargas à cabeça, mas eles não aceitaram, rodilha é só de mulher. Aí fez dois arcos com três flechas cada um, e eles pegaram e saíram fora. Gostaram só das coisas de homem, de mulher não ${ }^{8}$.

Aí foram matando passarinho, calango, por aí. Saíram, e ficaram embaixo da porta ${ }^{9}$, deram volta na casa e encontraram a mãe de criação, que falou que não brigassem com ninguém.

Mataram um calango. O menino disse ao pai que matara o calango, que era avô deles; Yawat disse que não podiam, porque era seu avô. Contaram os cinco dedos do avô e é verdade que ele tem cinco, como a gente. [O intérprete acrescenta: "Eu também contei, no outro dia, e é igual à mão da gente."]. Depois enterraram o calango, porque era avô deles; por isso até hoje não se come calango, porque é nosso avô ${ }^{10}$. Até caraíba não come. Aí não jogaram fora o calango ${ }^{11}$.

Então encontraram o calango azul, ele falou: "Que estão fazendo aqui, meus netos?" "Caçando." "Vou contar história para vocês: lá no meio do abacaxi do mato, está a avó de vocês, que matou sua [vossa] mãe. Então

\footnotetext{
7 O "quartinho", miritsi, é um pequeno recinto construído no interior das casas e no qual ficam confinados os indivíduos de ambos os sexos submetidos a reclusão ritual.

${ }^{8}$ A definição de entidades através de atributos de ordem material (rodilha $\mathrm{x}$ arco $=$ mulher $\mathrm{x}$ homem) ocorre outras vezes na mitologia xinguana, principalmente no mito de origem das tribos (mito 2), em que os itens de especialização manufatureira são os atributos em questão (p. ex. arco x rifle = Kamayurá x Caraíba).

${ }^{9}$ Isto é, na soleira. Nesta situação aparecem diversas vezes Kwat e Yaí.

${ }^{10}$ São mal conhecidos os motivos das restrições incidentes sobre a morte e consumo da maioria dos animais de caça entre os Kamayurá (agricultores e pescadores). Este é um exemplo. Oberg (1953:19) informa que matam mas não comem o veado, por vingança da destruição feita por ele na roça de mandioca plantada por Pakue (n) (v. tb. mito 24). Sobre restrições deste tipo entre os Suiá, v. mito 30; aliás, ignoramos se se trata, nesse caso, de um comportamento efetivo ou apenas de uma atitude depreciativa dos Kamayurá.

${ }^{11}$ O "parente" é enterrado, ao contrário do comum dos animais mortos e não comidos, que são deixados para o Urubu (v. mitos 18,19,20,21). Temos informes de que correriam a mesma sorte os corpos dos feiticeiros ( mua $(n)$ ngyat) mortos em represália de suas atividades.
} 
vou levar vocês lá." Aí eles diminuíram, ficaram pequenos assim, desse tamanho [indica com a mão uns $40 \mathrm{~cm}$ ], e foram lá ver a avó deles. E o calango foi embora. A avó viu-os e começou a brincar com eles; debaixo do pé dos meninos, tinha pedra para matar a avó. Ela brincou com um no colo, e depois de brincar, botou no chão e pegou o outro. Quando o outro, ele meteu o pé com força para pular, em cima do coração da velha; ela morreu. Nesse tempo, ainda não tinham nome, os meninos. Quando voltaram para casa, falaram com o pai, Yawat achou bom, porque ela tinha matado a mãe deles.

Kuyatìti [perdiz] era também avó deles. A mãe de criação falou para não mexerem no amendoim dessa avó. E eles disseram que não sabiam que estava na roça da velha. Escondidos, foram roubar amendoim, a perdiz veio e viu, achou que eram dois meninos que não tinham mãe. Disse: "Vocês chamam para ela [a mãe de criação] mãe, mas ela não é mãe mesmo. Mãe mesmo de vocês está enterrada no meio da aldeia." Eles responderam: "Vovó, conta a história para a gente agora." Ela contou que a mãe estava enterrada bem no meio da aldeia, que a avó deles tinha matado. Os meninos foram para casa, e ficaram chorando embaixo da porta. A mãe viu e soube logo porque estavam chorando, e quem é que tinha contado. Aí saiu e perguntou para eles que é que tinham. Eles disseram que sabiam, ela disse que era certo e que ela era irmã da mãe deles. Então perguntaram onde estava enterrada, a mãe e ela disse.

Foram lá, perto do buraco, choraram primeiro em choro de Kamayurá, depois de Kalapálo, Kuikúro, Mehinaku, Yawalapití, Awetì, Waurá, Trumaí, o resto do Matipú, Kayabí, Yurúna, Txukahamãi, depois Suiá, depois Txikão, depois acabou ${ }^{12}$.

"Vamos agora experimentar tirar a mãe do buraco, para ver se está boa." Chamaram, ela respondeu um pouco, eles tentaram, ela respondeu, muito fraco. Eles experimentaram, chamando "mamãe, mamãe, mamãe", ela respondeu sempre, fraco. Cavaram e tiraram a mãe do buraco, puseram fora e chamaram. Ela respondeu, fraco, e eles viram que não dava de falar mais, os bichos da terra tinham comido a garganta dela. "Se você tivesse chamado antes, tínhamos tirado você de lá, antes."

Aí convidaram Tumutumuri para enterrar a mãe deles. É um marimbondo, amarelo, com cabeça vermelha, que faz buracos no chão. Aí chamaram, convidaram para enterrar a mãe deles. Quando acabou de

${ }^{12} \mathrm{O}$ inf. enumera tribos xinguanas e marginais (Simões 1963) e refere-se às suas particulares formas de choro ritualizado. 
enterrar, fizeram banho nele primeiro. Depois urucu na cabeça dele, $a k a(n) w a(n) n g$, por isso a cabeça dele é vermelha ${ }^{13}$.

No outro dia, o pai dos meninos, Yawat, queria que eles andassem como onça, e tentou fazer pernas e braços, tudo igual onça. Mas quando ele puxou a cara deles para ficar igual onça, eles não agüentaram, começaram gritando, "Me salva, me salva!" - chamando Kawabib ${ }^{14}$. Aí os Kawabib vieram e Yawat ficou com medo. Então os meninos atiraram o pai e a mãe de criação lá para o céu, e o nome deles agora é İwakakape ayrupi ("os que estão na Via Láctea") ${ }^{15}$. O resto do pessoal da onça foi mandado para o mato, são as onças todas de agora. Estão por a i $^{16}$.

Passou um pouco, Mavutsini( $n$ ) chegou [do] Murena ${ }^{17}$, lá na aldeia do Yawat, e achou só os netos. Perguntou onde estava o pai, eles disseram que estava no İwakakape. Então chamou-os para morarem no Murena, lá iam fazer muita coisa.

Eles aceitaram ir para lá. Chegaram na aldeia de Mavutsini( $n$ ) e o pessoal perguntou o nome deles. Ai disseram: "Tsaukuma". Ai disseram-lhes: "Não, esse não pode ser seu nome, de vocês dois. Vocês querem levar meu nome? Meu nome é bom." Aí Kwarayumia, bicho parecido com cigarra, pretinho, grilo, falou isso: "Meu nome é Kwat (sol) Yaì (lua), Kwat o mais velho, e Yaì mais novo." O mais novo chamou-se Lua, o mais velho, Sol. Aí os meninos quiseram. Quando mudaram de nome, moravam lá no Murena ${ }^{18}$.

Do Murena, Savuru trouxe muito colar, para fazer visita lá no Kawira (n) ng ${ }^{19}$, na boca do [rio] Tuaturi, e lá encontrou ariranha pescando com rede. Ela desceu, veio perguntar o que estavam fazendo. "Nós estamos

\footnotetext{
${ }^{13}$ Aka(n)wa(n)ng é o nome genérico da pintura de cabeça, e o Tumutumuri passa por rituais de supultamento idênticos aos de hoje.

${ }^{14}$ No mito sobre o javari, que recolhe, Galvão cita os Kawabib. Segundo esses autor, é o termo geral usado pelos Kamayurá para designar as tribos hostis que faziam incursões na área (Galvão 1950: 355). Vimo-los usar a expressão como equivalente de "índio bravo", "inimigo".

${ }^{15}$ As Guias do Cruzeiro do Sul (alfa e beta do Centauro) são chamadas Yawat iwakakape, a Via Láctea, literalmente "caminho do céu".

${ }^{16}$ A luta de Kwat e Yaì com a tribo de seu pai, recorre em diversas variantes, de forma mais elaborada. V. Laraia 1967:17-19. Para outras tribos xinguanas, v. Carvalho 1951:16-25 (Kalapálo); Steinen 1940:477-490 (Bakairí); de Kalukuma(n), velho Awetì, recolhemos uma, já com indícios de aculturação $(\operatorname{Mavutsini}(n)=$ Jesus Cristo; os caraíbas, criados a partir de barro - negro e branco...).

${ }^{17}$ Murena, na confluência dos formadores do Xingu, é o principal palco da ação mítica, e considerado pelos Kamayurá como centro do mundo. No local, já uma cachoeira que desempenha importante papel em diversos relatos.

${ }^{18}$ Variantes deste trecho: v. mito 10.

${ }^{19}$ É o local onde até há pouco morou Maluaré, índio Karajá residente no Xingu, no lugar de um antigo posto do S.P.I.
} 
querendo pescar." Aí ela emprestou a rede, mas ele achou que era muito perigosa, que podia cair nela quando tomasse banho.

Aí saíram de casa, levantaram cedo, depois do galo cantar [sic]. Tomando banho, indo mais no fundo, o rapaz caiu na rede e morreu. A mulher dele achou que estava demorando, foi ver, as duas mulheres dele foram ver, estava morto na rede que ariranha emprestou. Savuru morreu, quando estava obedecendo ao conselho de ariranha, de ir olhar a rede quando o galo cantar. Foi aí que ele morreu; Savuru era gente. Veio do Murena, com duas mulheres. E as duas mulheres acharam-no morto: "Porque é que vocês fazem coisas dessas para os homens?" E choraram. Aí a mulher mandou a ariranha avisar Kwat e Yaì que Savuru estava morto.

Então chegaram Kwat e Yaì lá no Kawira(n)ng, e choraram muito. Aí levaram as mulheres, voltaram para Murena,[mas antes] demoraram muito tempo lá [no Kawira(n)ng], e depois ficaram com muita fome: "Lugar ruim esse onde não se come nada." Então disseram-lhes: "Sei de um lugar aqui onde há muito peixe, aqui. É o lugar de Ayanari” (também é gente). Aí saíram, chegaram lá, foram bem recebidos. Ayanari pediu para não falarem bobagem, senão podia acontecer alguma coisa. Kwat era perigoso. Ayanari perguntou o que queriam, disseram que queriam água, que foram atrás de água. Ele disse que tinha, mas era suja. Mostrou e eles foram tomar banho com Ayanari, que tinha água guardada numa casa que se chama Tapwi (n) que é o nome da casa de Yakui. Aí Ayanarì foi matar peixe para Kwat, lá na casinha. Matou só peixe elétrico, Wîrake, peixe ruim, e cozinhou. Só peixe com muita espinha, para que os dois Kwat morressem. Peixe bom mandava soltar. Aí cozinhou e deu a panela cheia para eles comerem.

Kwat pensou: "Isto aqui tem muito espinho, vamos pedir a $B o(n) k o(n) b o(n)$ [socó] a colher dele.” Ele emprestou. Aí comeram bem, não aconteceu nada. Acabaram de comer, tudo.

Passaram três dias na aldeia de Aynari, e voltando a Murena, fizeram muitas coisas, máscaras yakuikatu, de kaba(n)bá(n), [outras coisas de que o informante não quer dizer o nome] e iwat; warayumia [trocano] também. Tudo isso, para roubar a água de Aynari.

Chegaram lá ao meio-dia, quebraram o tanque de água com as bornunas, havia bichos lá dentro. Os bichos mataram todo o pessoal de Aynari. Ele reclamou, que ia ficar sem água, sem aldeia. A ariranha estava, também, no meio dos bichos que brigaram com Ayanari. Hopap [acabou] ${ }^{20}$.

\footnotetext{
${ }^{20}$ Este tema é retomado, adiante, noutros textos: v. mitos 13,14. Sobre a associação de máscaras, flautas e casa de yakui com a água e peixes, v. também mitos 5 e 29, e índice: Yakui, Tapwi $(n)$.
} 


\section{2- ORIGEM DAS TRIBOS}

Mavutsini $(n)$ foi que começou a fazer nós, vocês, todos. Mavutsini( $n$ ) fez o primeiro arco [preto]. Depois fez o arco branco. Depois ele fez borduna. Depois ele fez as armas de vocês, rifle (.44; .22), chumbeira ${ }^{21}$.

Mavutsini( $n$ ) foi tirar madeira; tirou quatro madeiras. Depois ficou fazendo, pintando os paus; ficou todo pintado. Depois ele foi para casa dele. Essas madeiras viraram gente, ele depois foi lá olhar, tudo saiu como gente. Depois pegou arco, borduna, flecha, rifle.

Ele falou para o Kamayurá: "Você vai pegar o rifle. E vai pegar o arco branco o Kuikúro; quem vai pegar borduna é o Txukahamãi; quem vai pegar panela é o Waurá."

Kamayurá foi, ia pegar rifle, aí correu foi pegar só arco. Mavutsini(n) mandou o branco pegar o rifle. Kamayurá pegou arco preto, iwirapapita $(n) n g$, achou bom. Mavutsini $(n)$ com raiva mandou o branco embora, para longe: "Você não pode ficar aqui. Se pegasse arco bom, podia ficar por aí; mas pegou rifle, vai embora."

Aí nasceu muita gente. Mandou que os Kuikúro, Waurá, Kamayurá, ficassem. Txukahamãi tiveram de ir embora, são índios bravos.

Por isso nós usamos arco; vocês usam revólver e rifle. Waurá usa panela.

\section{3- ORIGEM DE KWAT E YAİ E DO KWARÌP}

Tinha árvore preta, então Mavutsini( $n$ ) estava querendo corda de arco; então foi procurar, disse: "Vou tirar corda de arco, quem tem é a Onça." A filha dele não queria que ele fosse, tinha medo de que a Onça o matasse.

Mavutsini( $n$ ) tinha cinco filhas; então ele foi tirar corda de arco, foi tirar corda da Onça [Yawat]. Ela tem a corda plantada, ele vem roubar, escondido. Mavutsini( $n$ ) tirou corda que era assim como corda de tucum. Yawat estava em casa; ele viu tirar corda, chamou seu pessoal para olhar Mavutsini(n): "Alguém está roubando nossa corda; vamos esperar. Quero dar-lhe uma flechada."

\footnotetext{
${ }^{21}$ Demonstramos (1996) que este mito corresponde a uma classificação das tribos do Xingu, e é esta uma das variantes mais simples, referindo o Caraíba, três grupos xinguanos e um marginal. Na variante Awetì colhida de Kalukuma(n) aparecem dez tribos xinguanas (atuais e extintas), cinco marginais, e uma exterior à área (Mundurukú), e duas espécies de Caraíba (branco e negro). É de notar que todas as variantes Kamayurá que conhecemos se caracterizam por sua simplicidade.
} 
Mavutsini( $n$ ) [ouvindo], falou: "Você não pode me flechar; eu tenho filha para você casar com ela." A onça pediu desculpa, dizendo que quem estava falando era um Amigo seu. Mas Mavutsini( $n$ ) disse que não que tinha ouvido. E prometeu: "Tenho filha para você casar." "Então não flecho mais você." E prometendo a filha, Mavutsini( $n$ ) foi embora.

Depois Mavutsini( $n$ ) chamou a Onça, Tìwa. Ela não deixou o Amigo, onça também, matar Mavutsini(n). Mavutsini( $n$ ) foi levou a corda de arco e chegou ao meio-dia. "Você já chegou, pai?" "Prometi vocês para casarem com a Onça." "Não quero, senão a Mãe da Onça vai me comer." Repetiu a pergunta a todas as filhas e todas recusaram.

No dia seguinte Mavutsini(n) foi cortar paus para Kwarip. Cortou dois, mais dois, seis Kwarip (2 de kamiuwa, 2 de kwarip, 2 de mayaka'ip). Mavutsini( $n$ ) ficou pintando os paus, fazendo Kwarip, gente. Quando acabou, ficou rezando. Aì Kwarip virou, ficou igual a gente.

Aí Mavutsini( $n$ ) foi procurar cabelo. Tsitsika é um passarinho que tem cabelo, então Mavutsini( $n$ ) trouxe o cabelo para o Kwarip, ficou igual cabelo de mulher. Faltava dente, ele fez dente de concha grande [aquática], 'ita(n), que é o raspador de mandioca. Mas os dentes quebrava e ele fez dentes de sementes de mangaba; ele mandou rir, ela riu e ele achou bom, os dentes eram branquinhos.

Aí ele falou para o pau: "Prometi minhas filhas para a Onça, elas não quiseram; agora vocês podem casar com a Onça. Agora as seis vão casar com a Onça. Prometi para ele.”

Então mandou quatro delas para a Onça, então ficou com uma. Entregou [às quatro que partiam] urucum para pintar e pente: mas uma delas esqueceu-os e voltou para buscar, pedindo que esperassem. Mas as outras não esperaram, e a outra não as achou, veio gritando, não as encontrou: entrou no mato e ficou morando. As restantes continuaram e quiseram fazer corda de buriti para a cintura ${ }^{22}$. Uma subiu [a palmeira], duas ficaram embaixo: uma das de baixo tirou unha, fez mutuca, que foi para cima fazer a outra cair. A de cima derrubou o palmito de buriti, que ficou embaixo com a ponta para a cima. Aí quando quis descer, a mutuca fez que caísse; o palmito entrou no ta(n)ma [órgãos sexuais] dela e matou-a. Ela ficou lá, sem enterrar.

\footnotetext{
22 Trata-se do uluri (tamehawp, kunya(n) kuabap), minúscula cobertura pubiana e respectivo cinto, que serviu a Galvão para caracterizar (1960) a área cultural do Alto Xingu ou "área do uluri». A variante Kalapálo publicada por Carvalho revela que a função dessa peça de vestuário é impedir as relações sexuais indiscriminadas (1951:16-25); o homem que a tocar será atingido de panema, isto é, má sorte em suas atividades, de caça e pesca principalmente.
} 
Voltaram a andar, às 3 horas chegaram no porto das onças. E disse uma [das moças]: "Vamos esperar aqui. A onça vai fazer uma flecha de assobio $^{23}$." Subiram numa árvore e esperaram.

Outra mulher, Nyiau(n)nakunya(n) [anu preto] foi ao mesmo porto, banhar-se. E ela disse para o anu, seu companheiro: "Dizem que somos pretos, mas nós somos brancos." (Eram pretos mais viam-se brancos). Aí a mulher de Mavutsini(n) [isto é, feita por Mavutsini(n)] riu e a anu achou ruim. Depois os anus correram.

As mulheres de Mavutsini( $n$ ) ficaram esperando. Anu foi contar à Onça, que disse que tinha de ir buscar [as moças]. Saiu jogando flechas de assobiar, até chegar nas mulheres. Mas elas não quiseram pegar as flechas: discutiam se eram da Onça ou daquele Amigo dela. Não pegaram. A Onça perguntou [a si própria] porque não as pegavam, [pois] Mavutsini( $n$ ) tinha prometido. Aí voltou. O Amigo jogou flecha e as moças pegaram, pensando que era da Onça.

Aí o Amigo pegou [as moças] e levou-as. As duas fizeram vento e abriram a roupa do Amigo e viram que tinha a bunda cheia de feridas. Aí viram que não era a Onça, mas seu Amigo. E foram para a casa dele. Mas a Onça ficou brava por causa disso.

O Amigo tinha Mãe; mas não tinha roça nem comia beiju: só fruta. A mulher do Amigo fez mingau de fruta, mas as mulheres não quiseram. De tarde, a Mãe da Onça estava usando polvilho. A mãe [do amigo] disselhes que não tinha beiju, só a onça tinha, e que fossem pedir massa de mandioca.

Foram e pronto: quando voltaram, disseram à mãe do Amigo que eram muito pobres e que não tinham beiju. Deram-lhe, e ela foi trabalhar, perguntando: "Por que vocês não pegaram a flecha da Onça?"

No dia seguinte foram pedir mais beiju. De tarde, a Onça disse para a gente dela: "Vamos caçar amanhã, todo mundo." A mãe da Onça disse às duas mulheres: "Venham ajudar amanhã, a fazer beiju para o pessoal que vai caçar." O pessoal saiu, mas a Onça ficou. Mentiu para os outros, disse que estava com os olhos doendo. Os outros disseram-lhe para voltar. Ela voltou; mentira dela. Quando voltou encontrou as moças lá e disse: "Agora vocês têm de ficar comigo, mesmo que seu marido volte."

\footnotetext{
${ }^{23}$ Esta flecha é de cana de ubá, e tem na ponta um coquinho com duas fendas perpendiculares a seu eixo, que provocam o silvo característico. Difere do comum das flechas xinguanas em não ter vareta (foreshaft), e na emplumação. Em vez da "emplumação costurada", característica do Xingu, a sua é do tipo "Brasil Oriental" duas penas atadas pelos extremos à haste e com uma torção aproximada de 90\% em relação ao eixo desta.
} 
O pessoal da Onça voltou de tarde e ela levou-lhe comida, lá fora. O marido delas veio buscar [as moças]. A mãe do Amigo disse: "Olhem, seu marido está aí, podem ir comer a carde que ele assou."

Elas tiraram beiju para levar, mas a Mãe da Onça, não as deixou ir. A Mãe do Amigo voltou de novo para buscá-la, mas elas não foram.

Elas fizeram kawi $(n)^{24}$ para a Mãe do Amigo beber, misturando com espinhos de piqui; os espinhos ficaram todos na goela; e mandaram-na embora, para o mato. Aí o Amigo veio, para buscá-las: fizeram a mesma coisa e mandaram-no embora, pelo mesmo caminho para o mato.

Depois, uma das moças já tinha filho na barriga, feito pela Onça. Estava prenhe.

A Mãe da Onça tinha muito piolho, pediu que catassem; a Onça avisou que não catassem, senão sua Mãe as comeria.

A Onça foi com uma das moças à roça; a Mãe da Onça pediu, e a que ficou foi-lhe catar piolho e comeu um com cabelo, que se enganchou na boca. Ela quis cuspir o cabelo e a Mãe da Onça achou ruim: "Você não está gostando de mim." E aí matou-a, e fugiu para o mato.

Quando a Onça voltou, a outra moça viu a outra moça morta: "Sua Mãe comeu minha irmã!" A Mãe da Onça foi morar escondida no meio do abacaxi do mato.

O avô da Onça chamava-se Tumutumuri [marimbondo riscado], e [a Onçal foi procurar que ele fizesse o enterro. Outro avô da Onça era Tanaba $(n)$ [formiga], que entrou dentro da barriga da mulher morta (pelo $\operatorname{ta}(\mathrm{n}) m a$ ) e tirou dois meninos. Tanaba( $n)$ olhou e disse à Onça que eram dois homens.

"Como vou criar?" - disse a Onça. [Tanaba(n)]: "Você pode fazer casinha lá dentro da casa, e guardar os meninos lá:" Aí a Onça "rezou"25, muito. Os meninos depois andaram. A irmã da moça que morreu fez uluri e pôs na porta dos meninos, pensando que eram mulheres. Depois o pai fez arco pequeno, e os meninos pegaram ${ }^{26}$. Eles andaram dentro da casinha, depois caçaram passarinhos fora de casa e calangos.

A Onça depois foi na roça, ma [na verdade] escondeu-se debaixo das folhas com a mulher, perto de casa.

\footnotetext{
${ }^{24}$ kawi $(n)$, bebida feita de beijus desmanchados em água fria. Não á a bebida fermentada - coisa desconhecida no Xingu - que, com denominação semelhante, tem larga difusão.

${ }^{25}$ Isto é, cantou fórmulas mágicas, acompanhando-se com um maracá.

${ }^{26}$ Os atributos mudam, o efeito mantém-se: uluri $\mathrm{x}$ arco = rodilha $\mathrm{x}$ marco.
} 
Aí [um dos meninos] disse ao outro: "Você pode flechar passarinho." Depois o menino foi roubar amendoim de uma mulher. Depois, a mulher falou para eles: "Ah, vocês estão comendo meu amendoim. Vocês não têm mãe; essa que pensam, é tia; quem matou sua mãe foi sua avó.” Aí quiseram saber da avó. E disseram à mulher qual o seu nome [isto é, como se chamavam eles próprios]: "Kwat e Yaì," e este era o mais novo. Aí ela contou quem thes tinha matado a mãe e onde estava. Ela mostrou e os meninos acharam a avó. Então eles mataram-na.

O menino veio chorando, pela porta - "Mãe, mãe, mãe..." Então o menino falou para a mulher do pai dele: "Você não é minha mãe. Você não é mãe nossa. A mãe já morreu, você pode contar onde enterrou mamãe.” Aí mostrou, aí os dois meninos foram cavar. Cavaram até achar. A mãe deles estava morta há muito tempo, tiraram do buraco. Aí o menino foi agarrá-la para levantar. Depois o outro foi agarrar ela, depois levantou a mulher, mas ela estava morta. Aí enterraram de novo.

Depois os meninos saíram de lá e foram embora, lá para Murena: $\operatorname{Mavutsini}(n)^{27}$.

Aí os meninos falaram: "Será que esse Kwarìp vai virar?" "Não, não vai virar mais, é só para lembrar sua mãe", disse Mavutsini( $n)$. E ensinou a fazer Kwarip. Depois convidaram outra tribo, todas as tribos vieram lá, para a festa.

Mavutsini( $n$ ) falou: "Bom, vamos fazer Kwarip, toda ano assim. Só para lembrar. Não é para virar não." Aí Mavutsini(n) falou: "Quando acabar de fazer Kwarìp tem de lavar lá dentro d'água. Não pode ficar aqui fora."

Aí, Mavutsini(n) mandou pareat para chamar outra tribo. Aí esses dois meninos estão tomando conta do Kwarìp. A tribo convidada não quis vir. Aí ele mandou convidou outra tribo, aí ela veio e fizeram festa.

Quando acabou a festa, os meninos levaram o Kwarip [para] dentro d'água, no lago pequeno que havia perto, para as outras tribos não verem o Kwarip. Depois fizeram mato para fechar o lago, para não se ver. Aí esconderam Kwarip. Até hoje, ninguém viu, Kamayurá, o Kwarip dos meninos. Só Trumaí viu. ${ }^{28}$

\footnotetext{
${ }^{27}$ Acompanhada de perto variante anterior (mito 1) até aqui, passa esta a tratar agora do primeiro Kwarip comemorado em honra de um morto, e não mais com intuitos criadores (ou transformadores): "Só para lembrar. Não é para virar não". E assim continuam a ser hoje feitos os Kwarip.

${ }^{28} \mathrm{O}$ Kwarip é a mais importante festa intertribal, e os troncos são efetivamente lançados à água, com o fim do cerimonial. V. mitos 4 e 5.
} 


\section{4- COMO MAVUTSINI(N) COMEÇOU KWARÌP}

Mavutsini(n) tirou madeira, para fazer Kwarip. Mavutsini(n) tirou madeira, quatro madeiras. Depois Mavutsini $(n)$ estava pintando esse madeira, para fazer Kwarip. Bom. Mavutsini(n) tirou jenipapo, para pintar esse madeira.

Depois Mavutsini( $n$ ) foi pescar, pescar muito mesmo, muito peixe.

Então Mavutsini( $n$ ) chegou lá... (Mavutsini( $n$ ) estava sozinho). Bom, então ele fez outro madeira, para fazer gente. Tirou jenipapo, estava pintando, depois Mavutsini $(n)$ botaram [botou a] madeira lá dentro da casa $^{29}$. Depois Mavutsini( $n$ ) saiu de lá, fechou a porta, depois, amanhã, de manhã cedinho, já está começando a virar, assim, gente. Aí ele [as madeiras] virou gente.

Aí Mavutsini( $n$ ) fez urua (urua para vocês se chama flauta), depois Mavutsini(n) deu urua para esse que [ele] fez, esse [de] madeira. Mavutsini(n) deu urua para o gente, dançar. Aí Mavutsini( $n$ ) acha boa essa dança, urua ${ }^{30}$.

Depois, Mavutsini $(n)$ mandou avisar a outra tribo para ele fazer fes$\mathrm{ta}^{31}$. Três outra tribo vem, fazer festa.

Aí Mavutsini $(n)$ estava pintando Kwarip. Estava assim, Mavutsini( $n$ ) estava fazendo bem enfeitado, esse madeira, igual gente. Depois essa outra tribo estava dançando, dançando muito mesmo. Acabar[am] de dançar, depois Mauntsini( $n$ ) pegaram o peixe, para a outra tribo. Muito peixe, muito beiju, muito kawi $(n)^{32}$. Depois, acabar de comer, depois dança. Muita dança mesmo. Bom.

\footnotetext{
${ }^{29}$ É muito resumida essa variante. Na realização atual da festa, os Kwarìp são preparados à entrada da aldeia. Entre os Kalapálo, observamos, em 1966, fazerem isto no interior da casa das flautas; e informaram na ocasião que os Kuikúro e Nahukwá-Matipú procedem do mesmo modo. Estas, são as três tribos Karib da área. Repara-se, no entanto, que aqui Mavutsini( $n$ ) está criando gente, para participar da festa; só na segunda parte do mito ele entra na sua preparação propriamente dita.

${ }^{30}$ Longas flautas feitas de secções de bambu e tocadas aos pares. Compõem-se cada uma de 2 tubos, com bocal, e válvulas de abertura quadrangular. Um par que medimos tinha de comprimento máximo, respectivamente, $233 \mathrm{~cm}$ para a flauta maior e $215 \mathrm{~cm}$ para a menor.

${ }^{31}$ O convite é feito por meio de enviados, pareat, em número de três, o principal dos quais é escolhido dentre os sepultadores do morto a quem se dedica o Kwarip. Para cada tribo convidada, vai um grupo de três pareat.

32 Fator de prestígio para o hospedeiro, a abundância de comida é medida de sua amabilidade para com os visitantes. O mito 27 ilustra um conflito surgido, em parte, por causa da falta de comida, e, portanto, de atenção dos promotores de uma festa de jacuí, em relação a seus convidados. As prestações e contraprestações em serviços (participação no cerimonial) e comida são importante fator integrativo no decorrer do Kwarip.
} 
Bom. Depois Mavutsini(n) tirou esse madeira, Mavutsini(n) levou esse madeira lá dentro d'água. Assim que ele começou festa, Mavutsini( $n$ ). Quem que começou festa foi Mavutsini(n). Esse chama Kwarip ${ }^{33}$.

Ele começou tudo qualquer coisa, esse Mavutsini $(n)$.

\section{5- PEIXES E ONÇAS NO KWARÌP}

Katsini( $n$ ) foi pescar, foi subir em cima de pau, esperando peixe, de manhã. Então o peixe de rabo vermelho e rosto branco, que agente chama ararapira [peira arara], quando viu $\operatorname{Katsini}(n)$, disse-lhe que não flechasse, que eles também eram gente. O peixe então convidou a ir com eles, peixes, a ir ao Kwarìp da mãe de Kwat e Yaì. Aí Katsini( $n$ ) teve medo, mas os peixes chamaram-no e atiraram-lhe água e foram embora mesmo. Ararapira disse que a água era o mesmo que o seco $^{34}$. Então disse a Katsini( $n$ ): "Seus filhos foram também, na frente" e eram dois, filhos da arraia e de $\operatorname{Katsini}(n)$ [ele os gerara enfiando os dedos no ânus da arraia, ao pescar].

Aí Katsini (n) foi. Kwat ia fazer Kwarip da mãe dele. Aí foram. Katsini $(n)$ disse: "Vamos embora. Você precisa ver meu filho".

Aí não deixaram ele dormir perto dos peixes que foram à festa [o inf. indica que ficou a mais ou menos $500 \mathrm{~m}]$, porque as piranhas estavam com raiva dele, queriam comê-lo porque ele matava peixe.

No outro dia saíram e foram dormir longe daquele lugar onde tinham dormido. Aí dançaram, ainda no mato, bo'at ${ }^{35}$. E o filho de Katsini( $n$ ) disse: "Por que você não fez uma para nós?" Ele respondeu: "Aí na frente eu corto taquara para fazer flauta." Aí todos dançaram, mas Katsini(n) e Ararapira ficaram de longe, só olhando. Foram lá e Katsini $(n)$ entregou urua para o filho dele. "É, a gente precisa urua mesmo, porque sem urua o Kwarip não fica bonito mesmo." Aí Katsini ( $n$ ) não ficou alegre, porque o filho não ficou para trás como tinha pensado. Aí voltaram a fazer a dança de bo' at, de noite. Faziam uma dança em cada pouso que faziam no caminho.

\footnotetext{
${ }^{33}$ Esquematicamente, dão-se as etapas da festa: corte dos paus; pesca; envio dos pareat: chegada e dança dos visitantes, e dos hospedeiros, separadamente; (luta); (distribuição de piqui por uma moça reclusa); dança (dos homens visitantes com as mulheres dos hospedeiros), antecedidas por distribuição de comida; arranque dos kwarì, jogados depois na lagoa próxima. Entre parênteses, ficaram as fase omitidas pelo presente texto.

${ }^{34}$ A respeito de como é concebida a água, v. mito 22,24 e 29.

35 Bo'at, dança do ciclo do Kwarip, em que os homens participam armados das coisas mais disparatadas (galhos, paus, vassouras, asas de pássaros) e à noite de tochas acesas, fazendo grande alarido.
} 
Aí Ararapira disse para Katsini( $n)$ : "Você está vendo aquele canto de sapo? Ele é igual a você, aquele sapo bem grande que a gente chama Maritawata; tem pé, tem perna. É isso que o sapo está cantando.”

Aí foram viajar, chegaram, viajaram e no meio da viagem, Kwat e Yaì tinham feito cachoeira para o peixe não passar, e para todo o peixe que ia para a festa, ficar lá preso ${ }^{36}$. Aí um Kara que era grande campeão e se chamava Karatuaruwiyap ["cará grande"], recebeu ordem de seu chefe para abrir a barragem para eles. Aí ele bateu o pé37, correu, bateu e abriu a cachoeira um pouco; aí outro irmão dele foi atrás, bateu também, aí abriu um pouco e saíram. Primeiro saiu o Muruta [bagre]. Esse começou a pular e não conseguiu passar no buraco que tinham feito, ficou embaixo da pedra: "Por isso você agora vai ter de morar aí, embaixo daquela pedra", disseram-lhe. Por isso Karikari, Muruta moram embaixo da pedra, ainda hoje.

Aí Ararapira disse: "Vamos dormir mais um dia. Amanhã vamos chegar lá. Aí o Wîrake [poraquê] disse: "Eu vou lutar com a onça vermelha. "Vou arrancar todos os araviri dele e jogar fora." A bicuda disse: "Eu vou lutar com o veado." Aí aquele peixe parecido com cobra, que mora no fundo d'água, Moikapit, disse: "Vou lutar com Kwat" - mas não podia porque ele (Kwat) era yayat ${ }^{38}$. "Mas vou lutar mesmo bem com força, acho que ele vai querer."

Aí chegaram lá, chamaram o pareat para trazer fogo. Foram, e o pareat não entendeu e todos ficaram com raiva ${ }^{39}$.

Aí levantaram de manhã, pintaram-se, e o resto de urucu que ficou nas mãos passaram nos paus, e no lugar onde passaram, os paus ficaram

\footnotetext{
${ }^{36}$ Uma cachoeira destinada a prender o peixe, aparece nos mitos 13 e 14, e nestes dois trata-se da cachoeira de Murena, feita com ninho de cupim. Steinen (1942:334-337) recolhe caso semelhante entre os Bakaíri, sendo que se trata da cachoeira ou Salto do Paranatinga. Esse ocupa, na mitologia Bakaíri, o lugar de Murena nos restantes mitos xinguanos conhecidos, e cf. Steinen (1940:483-485) foi também feito de ninho de cupim.

${ }^{37}$ Bater com o pé no chão é, da parte dos participantes da luta corpo a corpo (yoetikawa) e antes dela se iniciar, uma atitude desafiadora.

${ }^{38}$ Yayat são os "donos da festa", seus promotores, parentes do morto e responsáveis pelos encargos econômicos mais pesados que acarreta. O principal dentre eles preside o cerimonial (ou delega o posto a alguém mais entendido), e fica impedido de tomar parte na luta. Adiante vê-se que Kwat não obedeceu à norma.

39 Durante a festa, os visitantes acampam fora da aldeia, e são servidos pelos pareat, que lhes levam comida, bebida e fogo. Qualquer descuido provoca exageradas manifestações de desagrado, e reações de ordem emocional, que podem tornar-se bastante graves num momento em que a autoconsciência tribal constantemente estimulada e os ânimos bastante excitados geram um clima de tensão crescente. Este só se aplaca após o desafio de yoetikawa.
} 
vermelhos. Primeiro, a turma da aldeia fez aquela dança chamada bo'at, saíram da casa anta, veado (etc.). Aí foram todos, os peixes, dançando bo'at, passaram atrás dos morerekwat dos peixes, e antes por trás dos kwarip $^{40}$. Aí yayat chamou. Escolheu os lutadores - anta, onça vermelha (tinha de todas as cores), veados ${ }^{41}$. Aí lutaram. Karatuaruwiyap ganhou; depois lutou outro, outro e foi indo assim. Aí a onça vermelha lutou com Wirake e arrancou-lhe todo o araviri ${ }^{42}$, ficou só um. E enquanto não arrancasse o Wirake dava choques, matava. Foi bom por isso que a onça arrancasse os araviri do poraquê; só ficou um. Aí Kwat pôs o vento ${ }^{43}$ e ele levou todo o araviri do Wirake.

(Sempre os nossos avós contavam essa hist6ria: isso não começou não foi ontem, não).

Aí Kwat chamou Moikapit para lutar: "Vamos agora lutar nós dois." Lutou com ele e Kwat ficou morto pouquinho, dois minutos, morrendo. Aí Moikapit foi correndo e enterrou-se atrás do apikawayat ${ }^{44}$ dos peixes e sumiu muito. Aí Kwat quando ficou bom, levantou-se e foi procurar Moikapit para lutar mais ainda. Aí os peixes que estavam ali perto disseram que Moikapit já tinha ido embora. Mas Kwat foi lá e viu o carvão que Moikapit passava no corpo $^{45}$, tinha ficado um pouquinho no buraco em que se enterrara. Aí pegou a redinha de matar peixe, procurou perto d'água e apanhou Moikapit pequeno. "Quem quer ser campeão tem de estudar para ser campeão”, disse Kwat com o Moikapit enrolado no braço. "Quem

\footnotetext{
${ }^{40}$ O lugar definitivo dos kwarìp é no centro do terreiro, virados para o nascente. Primeiro entram os morerekwat (capitães), acompanhados das mulheres, e sentam-se em banquinhos, com elas no chão, à sua retaguarda. Depois vem o resto dos homens de cada tribo, à vez e em grupo, dançando ho'at. ${ }^{41}$ O yayat escolhe os melhores lutadores de sua tribo e desafia, uma por uma, as visitantes. Reparese que a luta opõe dois grupos distintos: peixes e animais terrestres.

42 Araviri, braçadeiras de duas "fieiras de flores de plumas" paralelas (nomencl. cf. Ribeiro 1957 :3842), atadas à altura dos bíceps.

${ }^{43}$ Sobre o vento (mágico?), v. Indice.

${ }^{4}$ Apikawayat (dono do banco) designa os indivíduos que durante os cerimoniais se sentam em banquinhos na aldeia visitada. São geralmente morerekwat, e representam as diversas casas da aldeia convidada, podendo ser substituídos por um de seus filhos. No caso de um camará ser chefe de casa e, portanto, de família extensa, pode ter também as prerrogativas de apikawayat; e o mesmo se aplica a um filho que o substitua. Temos, no entanto, indícios de que antigamente apikawayat era sinônimo de morerekwat. "Ficar morto pouquinho" pode-se equiparar a "perder os sentidos"; mas o conceito de "morte" parece bastante amplo: há morte real, morte simbólica e ritual da iniciação xamânica, e morte "temporária" da perda dos sentidos, pelo menos. Tal extensão do termo, aliás, parece provir de má utilização da língua portuguesa.

45 Para lutar, os homens passam fuligem em todo o corpo, e sobre ela fazem as pinturas corporais propriamente ditas. Por cima, untam-se de óleo de piqui, para ficarem escorregadios: mas quando são especialmente hábeis, os "campeões" (makariat) desdenham untar-se.
} 
não quiser ser campeão não passa remédio, quem quiser ser passa e fica campeão mesmo. Passa sempre" ${ }^{46}$.

Aí rodos os peixes dançaram urua, como dançamos agora. Karikari começou a tocar e a dançar também. Aí todo o mundo disse: "Não se pode dançar com Karikari porque ele não é bom não.” Porque ele abria os braços e apertava e levava a mulher para o rio e as mulheres ficavam presas lá ${ }^{47}$.

Demoraram um pouco e a Ariranba chegou lá onde estava a festa, porque por aqui não tinha peixe, estavam todos lá. Aí todos os peixes sumiram, esconderam-se na casa de yakui; Katsini $(n)$ pegou um assador de beiju bem grande e prendeu o peixe todo lá. Aí ficou só Katsini( $n$ ) no meio do terreiro. Aí a ariranha perguntou pelo peixe. E ele respondeu: "Não sei onde está o peixe, o peixe não está aqui não."

Aí Katsini $(n)$ soltou um peido. As ariranhas ficaram assim, porque naquele tempo não tinham bunda para cagar. "Rapaz, daonde você peidou?" Ariranha toda ficou doida: "Daonde você deitou esse cheiro bom? Que nós nunca sentimos?” (As ariranhas só vomitavam, não cagavam ). Aí Katsini( $n$ ) deu vontade de cagar e pediu licença às ariranhas. Elas pediram para ir junto, olhar. Aí perguntaram: "Como você faz cu?" Katsini(n) falou: "A gente faz ponta de pau, bem ponta, aí a gente faz cu." Aí Katsini ( $n$ ) cagou e as ariranhas ficaram doidas, dizendo: "Já vem, já vem!" Aí saiu o cocô dele, vai saindo, vai saindo, todo o mundo ficou olhando.

Aí voltaram, as ariranhas, disseram: "Katsini $(n)$., como vocês fazem cu?" [Katsini $(n)]$ : "Vocês agüentam fazer? Tem de ficar tudo de quatro pés. Aí agente começa lá da ponta e vai até acabar. Assim a gente faz cu." Aí pegou o arco, fez ponta bem feita e mandou ficar de quatro pés, de olho fechado. Aí ficaram todas de quatro pés. Ele fez ponta bem feita. Aí correu de lá, furando, vai furando. Quando ficou uma só, todos os peixes disseram: "Katsini $(n)$, mata todas essas ariranhas" - porque tinham medo delas. Aí a ariranha levantou, olhou assim e viu todas as outras mortas, com a bunda furada. Quando ela viu, correu e caiu no rio, e Katsini( $n$ ) foi atrás, caindo também. Só a conseguiu ferir um pouco, e fez assim cu. Por isso a ariranha ainda vomita em vez de cagar. O cu dela é como o buraco desta conta de colar.

\footnotetext{
${ }^{46}$ Os homens escarificam-se e passam sobre os arranhões água com diversas folhas e raízes maceradas. Com um objeto semilunar feito de unha de tatu gigante, sobre o qual foi vertido óleo de piqui antes de aquecer o instrumento, esfregam-se as articulações para as "esquentar". Gordura de cauda de sucuri também é usada no corpo. Tudo para "ficar duro", forte.

${ }^{47}$ Sobre o comportamento do Karikari, v. mito 37. A respeito desta fase da festa, v. nota 33.
} 


\section{6 - MAVUTSINI(N) TENTA RESSUSCITAR FILHOS SEUS}

Mavutsini( $n$ ) quis refazer um filho morto, com um pau que pintou e enfeitou. A transformação começou por cima. Como um outro filho olhou, só metade virou gente, e o resto continuou de madeira.

Um filho de Mavutsini $(n)$ morreu; dois dias depois foi desenterrado, e Mavutsini( $n$ ) quis ressuscitá-lo. Como um outro filho viu quando metade daquele já saía do buraco, ficou assim mesmo [sem se transformar].

Das duas vezes Mavutsini $(n)$ ficou bravo. Disse ao filho [que olhou] que fazia assim para que ele também ressuscitasse depois de morto. Como ele tinha olhado, agora não podia mais [ressuscitar gente por esse processo] ${ }^{48}$.

\section{7 - COMO MAVUTSINI(N) FEZ PÁSSAROS E OUTROS BICHOS}

Mavutsini( $n$ ) fez muitas ceras [figuras de cera], igual passarinho, abe1ha. Fez qualquer bicho. Mavutsini( $n$ ) fez casa e guardou os bichos de cera. De manhã já estavam falando, ele abriu a porta e mandou sair. Aí ele deu os nomes dos bichos, de todos os bichos. Disse-lhes como tinham de fazer [como se comportariam]. E mandou os bichos para o mato: "Agora podem comer fruta... [etc.]." Passarinho come gafanhoto; anta come qualquer fruta do mato. Anta come fruta de buriti.

Mavutsini( $n$ ) deu arco às pessoas, para flechar peixe, para comer e assar. Branco caça com espingarda, qualquer bicho ele come. Primeiro fez gente. Depois os bichos. Mavutsini $(n)$ morava em Murena. Ele queria fazer os brancos e Kamayurá morarem juntos, mas o branco pegou rifle, [por isso] foi embora) ${ }^{49}$.

\section{8 - COMO MAVUTSINI(N) COMEÇOU PAJÉ}

Primeiro Mavutsini( $n$ ) fez boneca, para nós chama taa( $n)$ ngap, esse nome, boneca, chama taa(n)ngap. Então Mavutsini( $n$ ) fez esse taa(n)ngap [de] madeira, madeira de taa( $n)$ ngap, boneca.

Então Mavutsini( $n$ ) faz rede, para ele [a boneca] deitar, para [eles] curar.

\footnotetext{
${ }^{48}$ Recorde-se a tentativa falhada de Kwat e Yaì ao desenterrar a mãe e tentar trazê-la de volta à vida; e o caráter comemorativo que passou então a ter o Kwarìp.

${ }^{49}$ Feitos de substâncias diferentes, cera e paus respectivamente, os bichos distinguem-se entre si pelo comportamento e alimento, enquanto os homens o fazem por atributos culturais.
} 
Bom. Mavutsini( $n$ ) fez cigarro, depois Mavutsini( $n$ ) vai curar ele. Então Mauutsini( $n$ ) ajuntou muito pajé, ajuntaram[-se] muito pajé, para curar esse doente. Então pajé ajuntou [perto de] esse doente, fez fumaça nele muito. Depois esse boneco fica bom ${ }^{50}$.

Mas Mavutsini(n) foi chamar, para nós chama Pita(n)wa(n) Paye. (Para vocês chama Bem-te-vi). Então Mavutsini $(n)$ chamou Pita $(n) w a(n)$, esse pajé grande, então $\operatorname{Pita}(n) w a(n)$ chegou lá para curar esse boneca que esse Mavutsini(n) fez; o Pita(n)wa(n) curou ele muito, deu multo fumaça nele, assim, depois fez esse boneco ficar bom.

Mas então Mavutsini( $n$ ) chamou o Inyakwaem (para vocês chama "bicuda"). Esse nome do pajé, Bicuda. Então esse Bicuda chegou lá, curou esse doente, não ficou bom ${ }^{51}$.

Torna a chamar outro pajé, pajé grande, chama Ka'a paye. (Para vocês, eu não sei o nome desse ${ }^{52}$. Nome de pajé, chama Ka'a paye. Nome dele mesmo Ka'a paye, pajé grande. Então Ka'a paye chegou lá, Mavutsini( $n$ ) deu cigarro para Ka'a paye, então esse Ka'a paye levantou, cura ele, aí então esse doente, fica assim, começar ficar bom. Esse Ka'a paye, mais grande pajé. Mas Ka'a paye sabe tudo curar. Depois esse boneco fica bom. Assim é que ele começou pajés3.

\section{9 - OBTENÇÃO DO FOGO}

Assim começou fogo. Antigo não tinha fogo, antigamente assava o peixe no sol, assava o peixe no sol até secar, mas o peixe não está assado bem não, fica assim meio cru mesmo, crua; assim mesmo os Kamayurá comemos, antigamente.

Depois o Mavutsini( $n$ ) apareceu lá, perguntava: "Como é que, vocês comem peixe, como é que vocês assa peixe?" Aí então outra tribo, essa

\footnotetext{
${ }^{50}$ As sessões de cura xamânica contam, no Xingu, com a participação de diversos pajés, além do que propriamente faz a cura. Temos indícios de haver curas coletivas, mas nunca pudemos observar nenhuma. Quanto ao mito, apresenta pontos de contato com os informes a respeito do treinamento do pajé-aprendiz, após sua doença iniciática. Neste, um pajé iniciado faz-se de doente, para experimentar as habilidades curativas do candidato.

51 "Curar", aqui, tem o valor de "tratar".

${ }^{52}$ Literalmente seria "pajé folha", "pajé do mato". Fumar sobre o doente e soprar a fumaça sobre ele, além de o friccionar com as mãos, é o método usual de tratamento.

${ }^{53}$ Depois, o inf. esclarece: "Mavutsini $(n)$ era pajé, mas Mavutsini( $(n)$ não sabe curar bem. Então esse Mavutsini( $n$ ) chama esse Ka'a paye, que ele cura bem esse doente».
} 
outra tribo dos Kamayurá dizendo para ele: "Nós pesca por aí, nós assa peixe com sol. Fica secando. Mas o peixe leva muito tempo para secar, não assa bem não. Então peixe, nós come peixe, assim mesmo nós comemos peixe crua. Mas esse sol não está assando bem esse peixe." Então Mavutsini $(n)$ explicou para eles: "Vocês não sabem fazer fogo, com flecha, pedaço de pau?" Aí outro falou para ele: "Não, nós não sabe." "Então eu vou ensinar para vocês como é que faz fogo". Então Mavutsini( $n$ ) pegou flecha, uma flecha. Mavutsini( $n$ ) pegou flecha, rachava, então Mavutsini( $n$ ) pegou cortada assim, pedacinhos. Assim, cinco pedaços, mais dez. Então Mavutsini ( $n$ ) ajuntou assim [em] cima dos outros. Então Mavutsini( $n$ ) amarrou na ponta, depois ele amarrou de novo, então ele quebrava o pedaço de pau, ele racha, e coloca de pé, assim. [O gesto exemplifica]. Então ele está botando flecha assim, aqui dentro, aqui ele amarra, aqui ele amarra. Então ele pega pedaço de flecha, assim ele faz buraquinho no meio, pega carvão, vai riscando assim, então Mavutsini( $n$ ) faz assim, o fogo. Então ele bota aqui dentro algodão, pedaço de barbante. Assim juntando. Pertinho. Vai fazendo, vai fazendo, daqui a pouco fumaça começando a sair, fumaça saindo, começando, começando, até pegar fogo ${ }^{54}$. Aí Mavutsini( $\left.n\right)$ explicou para ele: "Eu faz fogo assim; quando eu não tem fogo, eu pego a flecha, e faz assim" Aí Mavutsini(n) explicou para eles. Bom. Outro dia, ele foi embora, na aldeia dele. Aí esse Kamayurá fez fogo, mas ele não sabe, não sabe fazer.

Então outra vez Mavutsini( $n$ ) chegou lá, aí tem muito peixe lá, esse Kamayurá pescava muito tempo, tem muito peixe mesmo. Então esse Kamayurá pegava esse peixe, está assando, leva no sol, aí Mavutsini( $n$ ) ficava olhando. Aí Mavutsini( $n$ ) disse para ele: "Ah, é assim que você assa peixe?" "É, é assim que nós assa peixe." "Assim não assa direito não. Assim

\footnotetext{
${ }^{54} \mathrm{O}$ aparelho de fazer fogo (tata) é de cana de ubá. Cortam-se diversos segmentos de uns 15 a $20 \mathrm{~cm}$, depois lascados em fatias longitudinais. Aproveitam-se destas as que têm a polpa aparente nas faces mais largas, que se sobrepõem paralelamente até ter uma pilha de 5 a $8 \mathrm{~cm}$, mais ou menos, de altura. A seguir arranjam-se dois pedaços de galho, de uns $15 \mathrm{~cm}$, que são rachados de forma a resultar uma espécie de pinça, onde se entala o amarrado das fatias de ubá. As pontas soltas das "pinças" são então atadas, completando o aparelho. Este depois é colocado no chão; as faces mais largas das fatias paralelas ao solo, a parte dos galhos na junção dos dedos das pinças enterrada naquele. Depois cava-se um buraquinho a meio da face aparente superior de uma das fatias de ubá, "lubrifica-se" com um pouco de carvão, e mete-se entre o aparelho e a terra a isca de algodão. Fazendo girar entre as palmas estendidas das mãos uma haste de uns $60 \mathrm{~cm}$ de cana de ubá, cujo extremo inferior verruma dentro do citado buraquinho, produz-se serragem incandescente, que, caindo sobre a isca, a incendeia. Sopra-se para obter chama, e a fogueira é depois construída à volta desse núcleo. Ou transporta-se a isca acesa, para acender fogo noutro ponto. O tempo gasto em verrumar e obter chama é de aproximadamente quinze minutos, às vezes menos.
} 
não assa direito. Você, você assa assim sem fogo? Não assa não. . ." dizendo para ele. "Assim (como) você assa peixe, custa a esperar assar, para você comer. Você faz fogo, aí você assa direito”. Então Mavutsini(n) pegou flecha de novo, faz fogo lá para eles, pronto, fogo saiu. Aí fogo apareceu. Aí arranjaram muito pedaço de pau lá, para não apagar, aí, eles assaram o peixe lá, Mavutsini $(n)$ comeram lá junto dele, pronto. Depois Mavutsini( $n$ ) foi embora na aldeia dele: "Pode fazer fogo como eu ensinei." "Sim." Aí foi embora.

Aí o fogo apagou. Não tem mais. Aí esse Kamayurá pegava flecha, racha, cortando em pedacinho. Aí ele faz fogo, aí ele faz, já sabe como é fogo. Assim que saiu fogo ${ }^{55}$.

\section{0 - ORIGEM DO NOME DO SOL E DA LUA}

Primeiro nome, esse Sol, chama Tìe' $(n) m$, porque o mãe desse Sol, morreu [há] muito tempo. Bem. Então o outro chama para ele Tire ì $n$ ) $m$ [sem mãe]. Então esse que chama Awara [raposa], foi lá. onde está ele. (O Sol tem casa, pequeno). Então Awara foi lá, procurava nome. Aí ele procurava lá: "Vocês tem mãe?" "Nós não tem mãe não. Nossa mãe morreu muito tempo." Bom. Aí procurava: "Como é seu nome agora?" "Nós chama agora Tîre’̀ $(n) m$." "Ah, não está bom para você. Eu tenho meu nome, é bom para você." Aí ele procurava: "Como é que é?" "Meu nome agora [para você], Tape iyaok" "Sim. Está bom"

Então esse Sol foi embora, caçar, então ele encontrou Kwarayumia, aí ele encontrou ele. Aí ele viu. Aí ele viu. Aí esse Kwarayumia falou para ele: "Que é que você está fazendo por aî?" "Não... Nós estava caçando por aí alguma coisa, para nós." Aí ele procurava: "Seu nome, como chama?" "Nós chama Tape akana(n) esse Tape iyaok." "Não, não está bom. Seu nome muito feio." Aí ele disse para ele: "Eu tenho meu nome, é bom para você. Quer ver?" Aí ele procurava: "Como chama agora?" "Seu nome agora, Kwat. Seu irmão chama Yaì." Aí ele achou bom. Aí eles chamou Kwat e Yaì.

\footnotetext{
55 A variante publicada por Oberg (1953:28) refere que o fogo foi primeiro roubado do Awara. Como era difícil transportá-lo, Yaì ensinou o processo de fazê-lo.

${ }^{56}$ Segundo outra versão (mito1), primeiramente os Gêmeos chamavam-se Tsaukuma. Tapeakana(n), "ziguezague do caminho"; Tapeyaok, "encruzilhada do caminho", "à esquerda do caminho".
} 


\section{1 - COMEÇO DA ESCARIFICAÇÃO}

O Sol (Kwat) é que começou a riscar. Irmão do Sol é Lua. Sol é mais velho que Lua. Sol fez yayap [escarificador]. Foi pescar, tirou dente de traíra pequena. Chamou uma irmã moça. Aí riscou o corpo dela, saiu muito sangue, que não parou.

Aí Lua (Yaì) disse: isso não é bom para riscar. Bom é dente de "cachorra". Sol disse a Lua como é que ele, mais novo, sabia disso, mais que o Sol. Aí foram pescar. Dormiram lá. Trouxeram muito peixe.

O Sol foi também quem fez jiqui. De tarde foram.

De manhã cedo fez yayap, de tarde chamou Lua. Aí chamaram a moça para experimentar: arranharam ela toda. Não doeu, só fez cócegas que mataram a moça.

"E agora?" Lua foi buscar pimenta, para passar no yayap. (Era água com pimenta e o yayap estava dentro.) Aí o Sol arranhou Lua, doendo muito. Quando acabou, Lua morreu.

Aí o Sol lavou o yayap, e riscou outra moça. Doía menos: "Está bom, agora não dói muito. Quem tem coragem risca com isso, quem não tem, não."

Aí Lua levantou-se, e disse que já não doía, lavando-se: "Está bom, agora não dói muito. Quem tem coragem risca com isso, quem não tem, não."

Todos dois fizeram muitos yayap. Aí deram um para Waurá um para Kuikúro, um para Kalapálo, um para Yawalapitín7 ${ }^{5}$.

\section{2 - KWAT COMEÇA AS RELAÇÕES SEXUAIS}

Antes, Kwat "trabalhava kumyâ" com o dedo, porque seus órgãos sexuais não endureciam: sua mulher achou que isso não era bom e mandou-o à casa de um indivíduo que tinha o pênis sempre em ereção. Ele foi, e Yai com ele. A meio do caminho já ambos estavam em ereção, e Yaì quis voltar; mas Kwat teimou em chegar até à casa desse homem5.

Chegados lá, ficaram em ereção permanente, sem conseguirem interrompê-la. Então, Kwat pediu ao dono do lugar que lhes fizesse baixar o pênis. Ele o fez, e dessa altura para cá, só quando se vão ter relações ele se excita.

\footnotetext{
${ }^{57}$ O escarificador, yayap, é feito de um pedaço triangular de casca de cabaça. Na base do triângulo, fica incrustada uma fileira de dentes de peixe-cachorra, muito aguçados, fixos com cera.

${ }^{58}$ As condições em que foi registado o mito impediram anotar o nome do indivíduo, que é conhecido.
} 
Depois, deram o ciúme para o Caraíba: só o Caraíba tem ciúme e mata a mulher, e briga com os outros. O índio [se é enganado] pode bater na mulher, achar ruim e fazer discurso, mas não pode brigar [com o rival] ${ }^{59}$.

\section{3 - COMEÇO DOS RIOS}

Por aqui não havia rios para a gente andar, então Kwat resolveu fazer uma lagoa grande como o mar, lá em Murena. Então o dono da água, Kanutsipem foi para lá (isso é história velha). Aí Kwat fez máscaras: biwat, yakuikatu, yakui, tawarit anya(n)ngu, para aprender a quebrar a água. E foi à aldeia de Kanutsipem para ver como se podia quebrar aquela água. Aí Kwat fez todos os rios, puxou o Paranatsi(n)ng (Batovi), lkatu (Ronuro), Paranatsi(n)ng (Ferro), Mebinaku paranatsi(n)ng (Kulisehu), Parana(n) (Kuluene) e o rio dos Suiá, Paranayap (Suiá-Missu), e para cima do rio dos Mehináku puxou outro rio. Então começaram a bater pau primeiro, dançando primeiro, batendo parecendo tambor, que Kwat fez (agora não tem mais). Foram, foram, passaram e passaram no Murena, onde fizeram os mama'e $(n)$ e o tambor, que também é de mama'e( $n)$ warayumiá, que é pau $^{60}$. Tinham três dias viajando para chegarem a Kanutsipem, para puxar o rio. Aí de manhã eles saíram, chegaram na aldeia de Kanutsipem. Aí foram dançar, rodando, assim. Foram também Mavutsini(n), Yai, Kwat; Kwat estava procurando Yaì que tinha sido engulido por um peixe grande. Aí chegou, gritou, procurando o irmão dele. Aí foi [procurar] Mavutsini(n), encontrou-o e perguntou pelo irmão, mas não o viu. Aí ele pegou [ninho de] cupim, quebrou, e virou o cupim em pedra e fez cachoeira. E ficou lá esperando ${ }^{61}$.

Aí foi pescando, Kwat matando peixe, aí apareceu o Kara na cachoeira. Era o Kara aruwiyap, mama'e(n). Aí Kwat quis flechar o Kara, mas o

\footnotetext{
59 Os padrões culturais em vigor impedem um desforço pessoal entre rivais em caso de adultério.

${ }^{60}$ Mama'e(n) e tambor, isto é, as máscaras e o grande trocano que antigamente era tocado diante da casa das flautas (Steinen 1940:123). Max Schmidt (1942:66) descreve-o assim, no interior do "rancho festivo": "No meio havia no chão um tronco de árvore oco de quase seis metros de comprimento, no qual custumam bater com um grosso bastão como si fosse uma trombeta (sic!), o que, em ocasiões importantes, serve para convocar a população masculina." (O grifo e o parêntese são nossos. Lima (1950:7) encontrou o trocano na aldeia Waurá, dentro da casa. Nas dos Kalapálo, Kamayurá e Yawalapití, em 1965. 1966 e 1969, não vimos nenhum. A respeito disto, v. Krause 1960:115. Mama'e(n). seres tutelares e sobrenaturais. O mito 1 informa que a água era guardada na casa das flautas.

${ }^{61}$ Isto, e o que se segue, é retomado no mito seguinte(14), "História da cachoeira de Murena". Também o Salto do Paranatinga foi feito, seg. a tradição Bakairí, com ninho de cupim (Steinen 1940:483-5; 1942:334-7.
} 
peixe disse que tinha vindo avisar, que sabia onde estava o irmão dele. Aí chegou, Kwat procurou [perguntou]: "Conta a história para mim." "Eu sei onde está seu irmão, sei o peixe que comeu seu irmão, Yakwau(n)n (peixe grande, como canoa, é de mama'e( $n)$, que está com seu irmão dentro da barriga. Agora você procura anzol e vai pedir anzol para Tapera (que é passarinho preto), para pegar o $\operatorname{Yakwau}(n) n$. O Tapera guardava o anzol no nariz e Kwat enfiou mosquito no nariz dele, e quando espirrou caiu o anzol e ele apanhou-o. Mavutsini(n) estava com Kwat. Ele apanhou o anzol e levou-o lá. Então o Kara que estava com eles pegou um cigarro, que Kwat fez. E na ponta do cigarro botou o anzol e o Kara foi lá, fumando, e Yakwau( $n) n$ pediu o cigarro para fumar, porque estava com a barri-

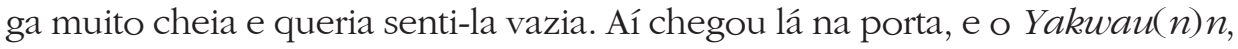
tendo pedido o cigarro, recebeu-o do Kara. Aí o Kara disse: "Enfia mais para dentro, que é bom para fumar." E o $\operatorname{Yakwau}(n) n$ enfiou o anzol lá dentro. Fumou, enfiou lá para dentro. Aí o Kara saiu correndo da casa e fez sinal para Kwat, puxando a linha. Aí Kwat puxou a linha e pegou. Aí já

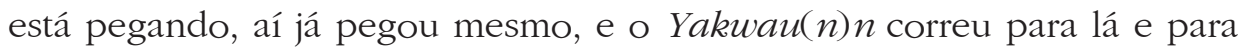
cá, e Kwat estava pegando na linha. E disse: "Não, não vou matar você, estou só procurando meu irmão." Aí Kwat puxou o Yakwau(n)n fora dágua. Tirou os ossos de Yaì da barriga dele e pôs no seco e cobriu com folhas cheirosas que tem no mato. Aí pediu para $\operatorname{Atsi}(n) n a u(n) n$ (é um pássaro que faz: "Txikão") para fazer pajé [pajelança] ${ }^{62}$. Depois para $\operatorname{Pita}(n)$ wa(n)paye ["bentevi Page"], depois para Yakwem [jacobim]. Aí pediu ao cupim e ele chegou e cobriu tudo: os braços, a cabeça, olhos, pés. quando ficou pronto, falou para Kwat: "Está pronto, teu irmão está pronto." Aí Kwat pegou um mosquito e enfiou no nariz de Yaì e ele espirrou, dizendo: "Eu estava dormindo". E o sol respondeu: "Não, você estava morto. Quem engoliu você era $\operatorname{Yakwau}(n) n$."

\section{4 - HISTÓRIA DA CACHOEIRA DE MURENA}

Um peixe grande engoliu Yai [Lua]. Kwat [Sol] estava procurando Yaì, mas não sabia que o peixe o tinha comido. Aí Kwat foi pescar, matou

\footnotetext{
${ }^{62}$ Tudo indica que os mama'e(n) têm olfato sensível. Não gostam do cheiro de cabelo queimado, de peixe assado, de relações sexuais. O pajé guarda, com seus apetrechos e fumo, uma espécie de baunilha que os perfuma, e usa umas frutinhas (takupe'a), aromáticas, em vários processos rituais. A tinta corporal de óleo de pau (ibìk) e carvão, misturados, também é desagradável aos mama'e (n); o corpo das crianças é pintalgado com ìbìk), com finalidades aparentemente apotropaicas. Estes fatos talvez expliquem o emprego de folhas cheirosas por Kwat, com fins curativos. No mito 14, Yaì também é engolido. No 15, é a vez de um pseudo-Murenayat.
} 
muito peixe, lá. O cará, peixe, veio, pertinho dele. Kwat quis flechar, mas ele disse: "Você quer me flechar?" "Quero." "Não. O peixe comeu seu irmão, está lá na casa." "Onde está esse peixe grande?" O Kara falou: "Seu irmão morreu; o peixe grande engoliu." Aí Kwat: "Que é que eu vou fazer?" Kara: "Você troca anzol. Quem tem anzol é Tapera." "Onde é a aldeia dele?" "Você entra pelo Ikatu (Ronuro) e pede anzol. Primeiro ele dá anzol pequeno; se não der grande, você põe mosquito no nariz dele."

Aí o Kwat saiu para lá. O Kara falou: "Se você não conseguir, amanhã eu ensino você a fazer." O Sol foi para casa de Tapera, que era muito velho e pediu anzol. Tapera deu, miudinho. Kwat disse: "Quero anzol grande." [Tapera]: "Não tenho."

Aí o Sol pegou mosquito, chamou Tapera para conversar, e soltou o mosquito que entrou no nariz de Tapera. Espirrou, e caiu um anzol. Sol riu: "Você mentiu. O anzol caiu de seu nariz. Agora você tem que me dar linha."

O Sol foi embora, esperar o Cará. Matou muito peixe e abriu [a barriga deles], procurando os ossos da Lua. Quando não achava, soltava os peixes vivos, num lago pequeno que fez. Os peixes não morreram, ainda estão lá (eu já vi). Então o Cará chegou: "Você trocou anzol?" [Sol]: "Então vem cá." [Cará]: "Você trouxe fumo?" "Não." "Vai buscar."

Pediu o anzol. "Agora, acende o cigarro." Botou o anzol dentro do cigarro e foi embora, fumando.

'Inyakunau(n)n (era o peixe grande) estava em casa, deitado. Sentiu o cheiro do fumo, pediu para fumar, ao Cará. Ele foi, sentou na porta e chamou 'Inyakunau(n)n, que sentou lá, também.

'İyakunau $(n) n$ disse: "Este fumo é bom, gostoso." O cará: "Vem para cá." "Não, aqui está bem." "Mais para cá." O peixe acabou saindo e fumando só na ponta do cigarro. Cará falou: "Não, fuma mais para dentro." Ele fumou. "Mais. Puxa mais." Ele puxou, ficou com o cigarro dentro da boca. Aí o Cará mexeu a linha, e o Sol puxou. O Cará correu e mandou puxar. O peixe entrou na casa dele, não queria sair. Aí saiu. O Sol puxava, e pegou.

Sol falou: "Não vou te matar. Eu só quero tirar os ossos de meu irmão." Aí tirou os ossos, juntou-os e soltou o peixe, com a barriga aberta.

O Sol levou os ossos para Murena. Aí o Sol desenhou igual a gente no chão. Pôs os ossos em cima do desenho, certinho.

O Sol ajuntou muito pajé. Muito mesmo. Aí chamou Pita(n)wa(n)paye, que cantou para Yaì. Depois foi buscar outro Kaa paye, que cantou também. Depois falou a outro pajé, $\mathrm{Na}(n) m u(n)$. Mas nenhum soube curar a Lua, só ficaram os ossos, lá. Depois o Sol pegou mosquito, pôs no nariz da 
Lua, que espirrou até levantar. Falou: "Estou dormindo aqui, dentro do Mato!" O Sol disse: "Que nada, foi peixe grande que enguliu você." Acabou.

\section{5 - BRIGA DA MURENAYAT COM KWAT}

Murenayat ${ }^{63}$ foi tomar a aldeia de Kwat, levando uma porção de gente dele, para brigar. Chegando à aldeia de Kwat, Kwat fez muitas mutucas, com as [suas] unhas, atirando-as no ar. Elas foram encontrar Murenayat e sentaram-se em cima dele, ele não as conseguia matar. Ele sabia que quem tinha feito era Kwat.

Kwat tirou mais três unhas, fez muitas mutucas que foram para onde estava Murenayat. Murenayat não quis brigar, mandou o pessoal voltar: "Vou sozinho até Kwat."

[Quando chegou lá], Kwat pendurou uma pedra por cima de Murenayat, e mandou-o sentar [por baixo dela], para o matar. Murenayat sentou, puxou o banquinho para fora [da linha] da pedra. Kwat trouxe kawi(n), beiju, peixe: "Pode comer aqui, não tem perigo" ${ }^{64}$. Quando Murenayat sentou, a pedra caiu, mas não o matou. Reclamou, dizendo que Kwat o queria matar, Kwat disse que não.

Murenayat disse que vinha brigar, Kwat disse que não, que não podiam morar juntos na mesma aldeia. De tarde, Murenayat foi embora, Kwat foi atrás, escondido. Quando Murenayat passou perto de Kwat, ele soprou, virando vento que fez Murenayat subir e cair no lago de Murena. [Daí em diante] Murenayat ficou morando no lago, não voltou para casa.

O pessoal de Murenayat foi procurá-lo na casa de Kwat. Kwat disse: "Ele já foi, ontem de tarde." O pessoal de Murenayat voltou, não fez nada porque tinha medo de Kwat.

O pessoal de Murenayat foi pescar, levando peixe assado (não sei porque), em Murena. O pessoal de Murenayat foi pela beira do lago, procurando peixe. Viram Murenayat lá dentro d'água, Murenayat pediu que o fossem buscar lá embaixo. [Alguns] caíram n’água e morreram.

\footnotetext{
${ }^{63}$ Murenayat, "dono de Murena", é denominação genérica aplicada a Mavutsini(n), Kwat e Yaì, sendo usada, também, como coletivo que engloba os dois últimos personagens. Mas o Murenayat a que se refere este mito dera-se indevidamente o apelativo, e há vaga notícia de uma disputa a respeito entre ele e Mavutsini(n). O texto apresenta curiosa justaposição de episódios que aparecem noutros mitos, alguns não publicados: o da pedra sobre o banco, o engolimento de Murenayat, sua ressurreição, etc. Isto faz crer que a presente variante é uma elaboração secundária, com fragmentos de diversas proveniências.

${ }^{64}$ Oferecer comida e um banco ao visitante é uma das normas da cortesia xinguana.
} 
O pessoal de Murenayat [então] pegou um peixe grande, que tinha comido Murenayat, e abriu a barriga do peixe. Estava cheia de ossos de Murenayat. Chamaram Kwat, e vieram Kwat e Yaì. Contaram os dedos, os ossos todos: faltava um dedo [o inf. mostra o lugar do sexto dedo que faltava, entre o indicador e o polegar de uma das mãos]. Não acharam mais esse dedo.

Com um pau, Kwat desenhou um homem no chão, e sobre o desenho colocou os ossos de Murenayat, só não achou o dedo. [Ao colocar os ossos, obedeceu à ordem normal, reconstituindo o esqueleto]. [Depois] Kwat quebrou folhas, cobriu os ossos e chamou o pajé Yakwe(n). Cantou muito [Yakwe $(n)]$ sem saber como curar.

Então Yai foi chamar Pita(n)wa(n), outro pajé. Kwat deu-lhe fumo, mas ele não soube curar.

Kwat foi buscar Inamu'ii(n), outro pajé. Chegando lá, Yai deu-lhe fumo, e ele cantou, e mexeu nas folhas. Murenayat mexeu um pouquinho. O pajé foi embora, porque não sabia curar.

Kwat fez mosquito (que morde agente) e pôs no nariz de Murenayat. O mosquito entrou no nariz; o pessoal de Murenayat olhava. Murenayat espirrou, até levantar ${ }^{65}$.

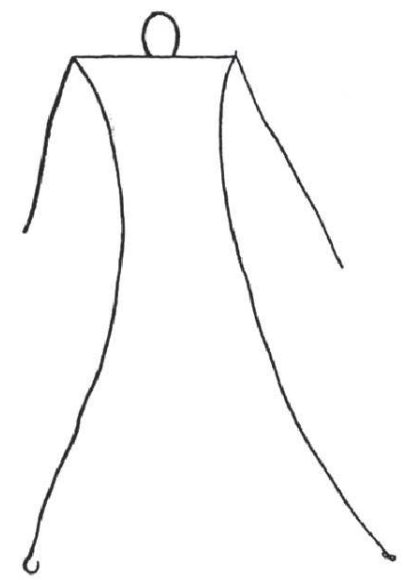

Figura 1 - Desenho feito por Kwat no chão. Sobre ele, reconstituiu Murenayat a partir de seus ossos.

\footnotetext{
${ }^{65} \mathrm{O}$ mosquito aparece com este papel várias vezes. Quanto a uma sua possível significação mágica, sabemos apenas que certos objetos de propriedade dos pajés - taa(n)ngap (boneco) - têm a propriedade de atrair mosquitos (muriçocas). Obtivemos um desses na aldeia Yawalapití; fora encontrado ao cavar para construir uma casa, e trata-se de um adorno cerâmico. Uma das razões dadas pelos Kamayurá para o abandono da aldeia do Tîwatìwari é a abundância de mosquitos, devida a um taa(n)ngap de Takumã, então chefe da aldeia.
} 
Aí Murenayat contou: "Estive dormindo, demais." Kwat falou: "Nada, você morreu, há muito tempo." Murenayat ficou bom, foi embora para a aldeia, e pagou a Kwat ${ }^{66}$. Murenayat queria dar-lhe muita "arara", mas Kwat disse que não precisava, que eles também sabiam fazer [enfeite de] arara: "Nós queremos é arco preto." O pessoal de Murenayat fez muitos, e Murenayat levou para Kwat. Aí Murenayat foi embora para a aldeia.

\section{6 - COMO KWAT E YAİ FORAM PARA O CÉU}

Kwat e Yaì saíram de Murena para a aldeia de Kamukuaka ${ }^{67}$; chegaram até lá, então Kwat pegou um arquinho, jogava flecha e furava a orelha. E fez dois furos na orelha de Kamukuaka. "Não, Kwat, assim mata a gente." Aí Kamukuaka foi lá, pegou osso de onça para furar orelha; e furou as orelhas de todos ${ }^{68}$. E disse a Kwat: "Assim é que é bom. Com arquinho não pode, não." Quando terminou de furar, gritaram e cantaram um pouco e terminaram de furar as orelhas. Então Kwat ficou muito tempo lá perto de Kumukuaka e Kwatfez $\operatorname{araru}(n) n$ [arara preta], e periquitinho também, que deixou dentro de casa com milho para comerem. A arara preta e- o periquitinho eram para morder e matar o pessoal de Kamukuaka. Mas a $\operatorname{araru}(n) n$ não fez esse serviço.

A irmã de Kamukuaka foi banhar lá fora e esqueceu a liga [jarreteira]. Então Kwat passou lá e apanhou, levou. Quando chegou lá na sua casa, com aquela liga fez cobra grande mesmo, Moi(n)buku, para mama'e(n) mesmo.

Para o lado onde desce o sol ficava a casa de Kamukuaka [nem Tawapi nem nenhum Kamayurá lá foram]; é no Batovi. (Os Waurá sempre vão lá passear). Kwat ficou muito tempo perto de Kamukuaka, Moi(n)buku chegou à porta de Kamukuaka e pediu menino para comer. Kamukuaka pegou menino e Moi $(n) b u k u$ comeu. Então ficou com dó dos meninos, não podia dar mais meninos. "Quando Moi $(n) b u k u$ vier, vamos dar pau para ele comer." Quando veio, atiraram pau da casa e Moi(n)buku comeu.

\footnotetext{
${ }^{66}$ A cura xamânica é cara, e acarreta pagamento em colares, penas de arara, etc.

${ }^{67}$ Só conhecemos uma outra referência a Kamukuaka, que mora numa cachoeira do Rio Batovi. V. Ferreira e Ballot 1955:9, que dão Kamukaka, cf. um relato, de origem Waurá-Mehinaku, de Cláudio Villas-Boas.

${ }^{68}$ Furar as orelhas faz parte dos rituais ligados ao ciclo de vida, e ocorre por volta dos oito anos de idade. Usam-se ossos de onça aguçados: v. p. ex. Myazaky 1964. Oberg (1953:64) afirma que o instrumento usado para a perfuração é de presas de peixe-cachorra.
} 
Aí Kamukuaka pediu a $\operatorname{araru}(n) n$ e ao periquito para abrirem a casa para eles saírem. De manhã pintaram-se todos para sair, para irem lá no céu. Quem foi na frente foi o macaco coatá, akiki, cantando como se canta depois de furar as orelhas, foi lá para o céu. Então Kamukuaka saiu para cima da casa e largou flechas para o céu, uma espetando-se na ponta de trás da outra, até chegar na casa dele. Aí passaram jarreteira para poderem subir e chegar ao céu. Yaì nesse dia não estava e Kwat também não, estavam pescando. Kamukuaka estava fazendo isso escondido. Akiki estava para subir para o céu. Kamukuaka tentou levar a irmã dele, mas ela não quis, só subia um pedaço, ficava com medo e descia. Por isso só os homens subiram, as mulheres é que ficaram. (Sempre nossos avós contavam isso).

Aí foram. A irmã dele fez buraco bem encostado à parede da casa, e ficou lá, tapando. Aí Kamukuaka entregou o caramujo de raspar mandioca, 'ita $(n)$, para ela, e ensinou: "Se $\operatorname{Moi}(n) b u k u$ subir atrás da gente, então você corta a corda para ela não subir." Moi(n)buku estava dormindo, e Kamukuaka estava aproveitando para subir.

$\operatorname{Moi}(n)$ buku levantou-se e veio à casa dele e chamou. Ele não respondeu. Ela entrou, procurando. Olhou, viu o buraco no teto e foi lá olhar. Então Moi(n)buku começou a subir. Aí a irmã de Kamukuaka saiu e cortou-lhe o rabo. Ela caiu. Depois tornou a subir de novo; a mulher voltou a cortar. Aí Kamukuaka chegou lá no céu, encontrou primeiro a aldeia da onça, quando chegou, e as onças não estavam lá, estavam pescando. Receberam-nos muito bem. Chegaram lá e as moças da onça escolheram marido entre eles. Do pessoal de Kamukuaka, todos casaram, ninguém ficou sem casar. Teve um que era feio, nenhuma mulher quis.

Kwat e Yai chegaram da pescaria. Quando chegaram da pescaria não havia ninguém. Olhou e falou para Yai: "Para onde eles foram?" "Foram lá no céu", disse Yaì.

Tinha Pikau-aruwiyap ["pomba grande"], que moravam na casa da onça, criada por ela, e ela avisou Kamukuaka que não mexesse com pikau-aruwiyap, porque era muito ruim para a gente. Então ele, Kamukuaka, perguntou: "Por que ela tem medo que a gente pegue?" Aí estavam sentados lá onde tinham encontrado peixe, quando começaram a pegar no Pikau-aruwiyap; e aí apareceram os dois Kwat por lá [isto é, Kwat e Yaì], logo que lhe tocaram com a mão [em Pikau-aruwiyap]. Aí a onça vermelha veio correndo, olhou para dentro da casa do pessoal de Kamukuaka, que estava cheia, olhou e disse: "Não está bom para a gente mais, Kamukuaka encheu a casa de gente." Aí a onça chegou em casa, combinou tudo para brigar com Kamukuaka, que tinha tomado a aldeia deles. 
Aí as onças cercaram a casa, aí saíram da aldeia e mataram alguns. O resto estava escondido. Aí chegaram às casas e perguntaram às mulheres: "De quem são estes arcos aqui?" "Não são de vivos, são dos que morreram já." Mas eles estavam era escondidos. Aí Yaì e Kwat estavam na casa de yakui e ficaram lá escondidos. Ai a onça disse: "Acho que ainda tem gente escondida na casa de yakui." Quando a onça botou a cabeça, Kwat e Yai flecharam a onça, e puxaram-na para dentro. Aí as onças todas perguntaram: "Tem gente aî?" E foram olhar. Mal meteram a cabeça, foram flechadas. Aí foram matando as onças, assim. E a onça perguntava: "Tem gente aí?" Pensava que as outras ainda estivessem vivas. Aí foram matando assim, matando, até que ficaram poucas onças, yawari [jaguatirica] também. Aí começaram a encontrar [descobri-los] lá, e quando Kwat flechou, yawari pulou e escapou, dizendo: "Tem gente escondida."

Aí, depois de quando a jaguatirica saiu pulando, os dois Yaì [isto é, Kwate Yaì saíram fora do tapwi(n) [casa de yakui], e com eles Kamukuaka. Aí brigaram com as onças e mataram um bocado delas. Por isso a onça ficou difícil para a gente. Se não fossem Kwat e Yaì, elas seriam como porcos [do mato], muitos, juntos.

Aí o capitão de Kamukuaka perguntou: "Como vamos fazer? Vamos comer?" "Não, a gente não pode comer." Se ele comesse, a gente comia [também] aqui. Mas resolveram só tirar-lhes as unhas para fazer colar e ficar bonito ${ }^{69}$.

(Daí por diante, Kwat e Yaì e Kamukuaka ficaram para sempre lá no céu. Kwat e Yaì, na altura de furar as orelhas de Kamukuaka, mudaram para sua aldeia e daí começaram e foram para o céu. [Esclarecimento do intérprete.])

\section{7 - HARAWI}

Um rapaz tinha um companheiro, seu amigo, com quem se dava. O companheiro morreu; disse, antes, que ia morrer, e que o chamaria. O rapaz pediu que "lá de cima" o viesse buscar, depois de morto.

Sete dias depois de morto, houve eclipse da lua. Aí o rapaz saiu pela estrada, de noite, chorando. Aí a alma do companheiro desceu e encontrou-

\footnotetext{
${ }^{69}$ Além dos colares de pescoço comuns, feitos de caramujo, há outros de unha de onça, usados sobretudo em ocasiões solenes, e consideravelmente mais raros que os outros, e valiosos. Oberg (1953:29) informa serem, os caçadores de onças, especialistas, que se pintam de negro e usam flechas com lâmina de bambu, como para a guerra. Não obtivemos confirmação para o que se refere à pintura negra.
} 
o; o rapaz, ao ver a alma caiu, "morreu", "morreu um pouquinho." O rapaz voltou a acordar, viu, tomou a cair; tornou a levantar, e não caiu mais.

"Vou levar você. Agora vamos brigar com o passarinho bravo." (Por isso pomos flechas no buraco, para brigar com o passarinho. O morto fica pintado e põe-se enfeite. No céu o morto fica com os enfeites, que nunca se tiram).

"Agora vamos subir". O companheiro soprou no rapaz e subiram, o rapaz de olhos fechados, até à porta do İwakakape. Na porta esperaram, esperaram pela alma dos Kamayurá mortos. Eles chegaram, todos enfeitados. Passaram todos e os rapazes foram atrás.

As almas têm medo do sapo que come gente lá, do caranguejo que aperta e mata as almas. Elas também morrem se pisarem sapé ${ }^{70}$.

O rapaz vivo, ia matando os bichos perigosos para as almas. Matou também o sapo, matou-o. Depois, o sapé, que o rapaz cortou. Aí acharam espinhos que o rapaz limpou. Aí acharam pássaro que queria comer alma de Kamayurá, que ele comia muito. E um urubu-rei de duas cabeças. Lá também tem um gavião que come gente (tem só uma cabeça) ${ }^{71}$. Passarinho bravo mata as almas e leva elas para o urubu e gavião comerem.

O rapaz vivo matava o passarinho bravo. Matou muitos. Ele queria matar o gavião, mas o companheiro não deixou, porque se matasse o gavião o céu desabava. "Este céu é dele, do gavião." Mataram os gaviões pequenos, e a alma do Kamayurá tirou penas para o vivo; de arara também $^{72}$. Brigaram muito com os passarinhos, morreram muitas almas. Quando o passarinho mata a alma, aí acabou, não tem mais.

A mãe do vivo chorava. Depois de três dias no céu, o companheiro levou-o de volta. Prometeu ir buscá-lo. Prometeu voltar em novo eclipse: só se briga com novo eclipse, com o pássaro. No céu não há mato, tudo é limpo. O dia e a noite são ao contrário daqui. As flechas são quebradas quando enterram [o morto]: lá estão inteiras.

\footnotetext{
${ }^{70} \mathrm{O}$ acesso ao céu faz-se por um buraco, e, para ir à aldeia dos mortos, segue-se a Via Láctea, ao longo, da qual há uma série de perigos que, vencidos, permitem atingir a aldeia, situada a noroeste. Se a alma os vence, alcança-a, e os vivos sabem disso ao sonhar com ela. Se sucumbe, morre, e então nunca mais a alma aparece em sonhos.

${ }^{71} \mathrm{O}$ İivutsi(n)ng moko(n)y aka(n)ng é figurado nos banquinhos ornitomorfos bicéfalos. O gavião grande, Wîrapi aruwiyap, é um ser mítico que tem seu equivalente zoológico no Wirapì (Barpia barpija L.). Embora um exemplar destes seja geralmente mantido numa gaiola nas aldeias, não obtivemos evidência de uma relação direta. O mítico habita afastado da aldeia das almas.

${ }^{72}$ Nos mitos que envolvem uma ascensão celeste, é comum o indivíduo que regressa trazer penas para a terra. V. mitos 19, 20, 21.
} 
Saíram [do céu] de dia, e chegaram de noite [terrestre]; trouxeram muitas penas de gavião. "Já vi como se briga lá. Vou voltar lá, e vou ficar, porque era bom brigar com o passarinho." O nome do rapaz era Barawi.

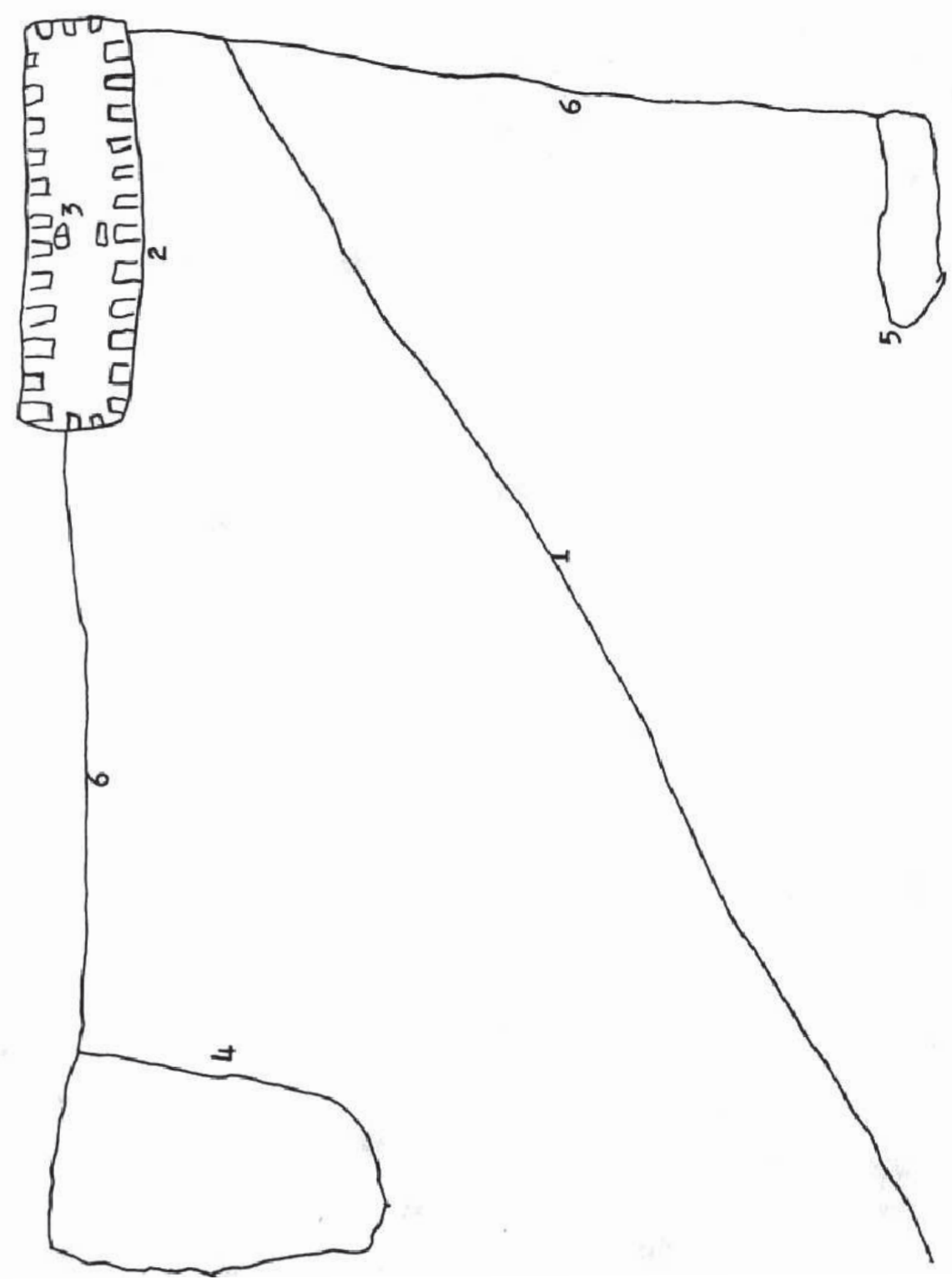

Figura 2: Aldeia celeste, das almas. 1) İwakakape, "O caminho do céu" (Via Láctea); 2) Aldeia celeste; 3) Tapwi (casa de yakui, as flautas secretas); 4) Lugar limpo de mato, onde moram o Urubú- Rei Bicéfalo, o Galvão e os passarinhos bravos. É onde as almas vêm brigar com estes. 5) Lagoa dos "bichos bravos" (v. fig. 3); 6) Caminhos. 


\section{8 - OS PESCADORES QUE FORAM AO CÉU}

[O inf. hesita se foram Waurá ou Kamayurá os personagens da narrativa. Depois decide-se $]^{73}$ :

Pode ser Waurá. Waurá foi pescar de noite, de canoa. Aí acenderam um sapé, para iluminar o peixe, e matar. Aí encontraram "pintada".

Aí İwakakape (Via Láctea) desceu a ponta dele, e a ponta caiu n'água, sem que o Waurá visse: ficou igual rampa.

Ele foi pescando, encontrou pintada na ponta do İwakakape, onde a água estava rasa. O Waurá pensou que era água, o İwakakape. Ele e o companheiro, alumiaram; aí a pintada andou, Waurá andou atrás e foram subindo, pensando que era água, até chegarem ao meio, por cima da água. No meio, o Waurá viu onde estava, e o İwakakape subiu e a canoa ficou. Eles ficaram sem poder descer. E o Waurá chorava, o companheiro perguntou como iam descer.

Aí continuaram subindo. $\mathrm{Na}$ aldeia havia Waurá dançando yakui: olharam para o céu, viram o Waurá no céu, aí mostraram aos outros, para verem o pescador lá em cima. Aí esconderam o yakui ${ }^{74}$ e chamaram a mulher do pescador para ver.

Eles foram para o céu, e não voltaram mais. No céu, havia muita gente, Waurá, Kamayurá, tudo. Lá tinha dança, comida, peixe.

O filho de pescador morreu [anteriormente], e a [sua] alma foi para o céu. Aí o pescador disse: "Vamos ver se encontramos meu filho." Procuraram na aldeia do céu, tinha muitos Waurá e Kamayurá. A casa do filho era bem no meio. Encontraram-no, e o filho ficou alegre. O filho perguntou como tinham subido e o pai contou.

Ficaram no céu muitos dias, e aprenderam a dançar e cantar amurikumã, mavurawa, kwarìp, yavari, todas as danças.

Estava com saudade, pediu ao filho para descer para junto da mulher. O filho morreu pequeno, [agora] já era grande. O filho foi falar com o Urubu, que tinha asas e podia levar o pai. Pediu-lhe para levar. O Urubu disse que sim: "De manhã cedo eu levo ele." "Tenho de pintar ele primeiro", disse o Urubu. Aí chamaram o pai e o companheiro, e

\footnotetext{
73 Os contatos freqüentes e amistosos são fator de difusão de mitos e outros relatos, ao que parece prontamente incorporados ao acervo geral. Daí que não seja raro haver hesitação quanto à identidade dos protagonistas. Talvez se possa falar de uma tendência etnocêntrica, no sentido de atribuir aos personagens filiação idêntica à do narrador. Isto acontece, por exemplo, com Mavutsini(n), mas não no mito em apreço.

${ }^{74}$ Sobre a proibição ritual que veda as flautas às mulheres, v. mitos 27 e 28.
} 
pintaram-nos com jenipapo. Primeiro pintaram o pai, depois o companheiro $^{75}$.

Bem cedo, foram na casa do Urubu; ele comia peixe podre. O Urubu ofereceu, e disse que se o homem não comesse, ele não levava. O homem comeu, e ficou querendo vomitar. Aí ele comeu. O Urubu levou o pescador, a mulher do Urubu levou o companheiro.

Pensando que o pescador tinha morrido, cortaram o cabelo da mulher dele.

Montaram no Urubu, de olhos fechados, e aí desceram. Lá de cima até ao chão levaram um dia de viagem. O Urubu não desceu na aldeia, desceu noutro lugar. Aí o Urubu pediu que dessem para ele os restos da caça que fizessem.

Depois chegaram a casa, falaram com a mãe, que julgava que tinham morrido. Aí contaram tudo à mãe do Waurá. Ela disse que os tinha visto lá no alto.

Aí o homem ensinou as danças para os outros companheiros da tribo.

\section{9 - KANARATİ E KANARAWARİ}

Kanaratì foi para o porto, banhar. Então Kanarawari estava cagando e ouvindo. Então Kanaratì arrancou flor de moitse $(n)$ 'e(n), raiz doce feito açúcar. Aí arrancou flor e mostrava para o companheiro: "Olhe, companheiro, esta flor é parecida com 'aquela coisa' da mulher de Kanarawarì." (Porque flor é parecida mesmo). Kanarawari tinha duas mulheres. Kanarawari estava lá ouvindo essa bobagem. Quando acabaram de contar isso, deram risada e Kanarawari então arrancou [a flor] e levou para a mulher dele, mostrando.

Chegou lá, falou: “É verdade que o ‘troço’ de vocês é parecido com esse? Kanarati estava lá na estrada falando." Aí ele e a mulher começaram assim a brigar, devagar. E disse: "É verdade mesmo, é assim que é o troço de vocês." Isso foi tudo no Murena mesmo.

No outro dia foram cortar Kamiuwa. Assim começou a briga deles, essa história deles. Então chamou: "Kanarati, vem cá." "Espera aí, vou lá na minha casa tomar bebida." Aí o avô dele perguntou: "Para que seu irmão está chamando?" E já sabia: era para carregar kamiuwa. "Você tem de levar cupim, galho, vento, não sei que mais, por aí assim [isto é: etc.]."

\footnotetext{
75 Sempre que o Urubu intervém para reconduzir alguém à terra, pinta-o com tinta de jenipapo. V. mitos 19, 20, 21.
} 
Foram. Kanarawari convidou Kanaratì, mas Kanarawari ficou em casa. Aí quando chegou lá, o cupim resolveu furar o pau para que ficasse fino e não pesasse muito. O cupim abriu lá dentro, tirando tudo o que tinha lá dentro. Aí pegou o pau, outro pegou no outro, Kanaratì pegou e voltaram correndo. Chegou tarde, quatro horas, por aí assim. Aí chegou. fizeram logo buraco para colocar esse kamiuwa, aí puseram-no meio caído e disse Kanarati "Agora você conserta, para ficar direitinho. Aí disse Kanaratì "Você vai consertar seu pau de rede"76

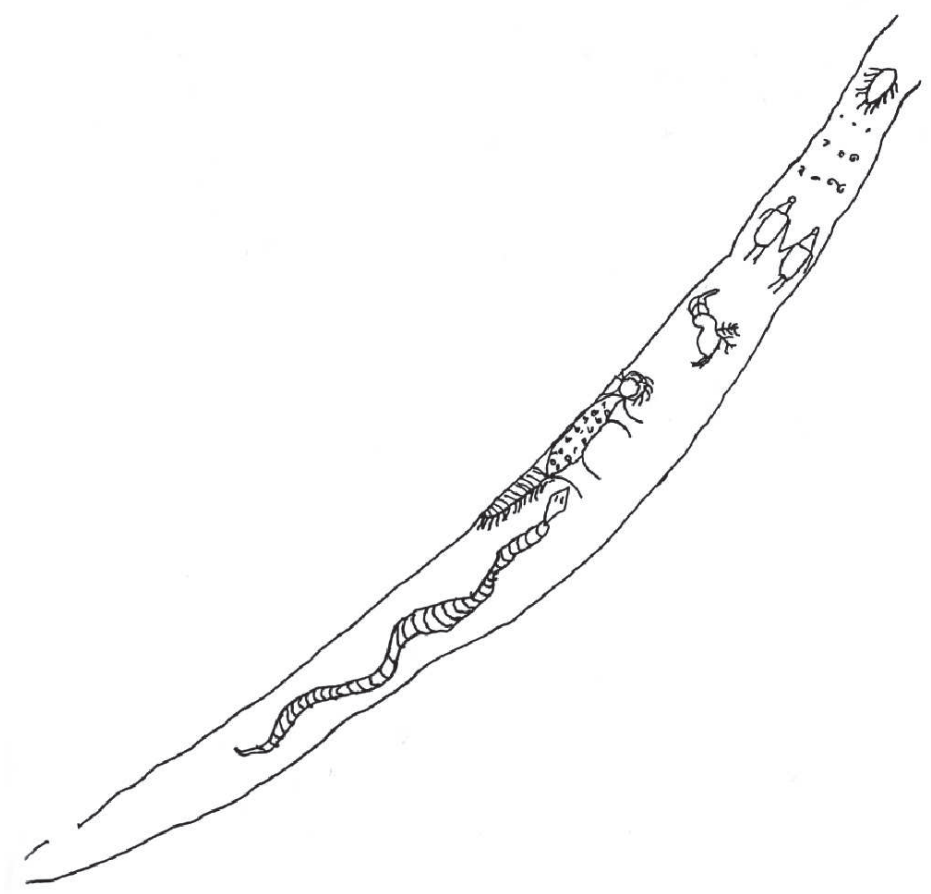

Figura 3: "Bichos Bravos" que moram na lagoa celeste. De baixo para cima: moi (cobra); kwatsiawat, que pega viado e onça e é comida de moi; warahoho, que apanha passarinhos e papagaios; anyãngu, que parece gente, mata e come os ossos das almas; iwikwat, buracos onde moram os os bichos e de onde sai a água; eyraruwiyap, abelha grande que joga espinhos nas almas. Havia estes "bichos "na lagoa onde Kanaratì foi tirar jenipapo (mitos 19,20,21).

Passaram cinco dias, Kanarawari pegou cobra grande mesmo convidou Kanaratì e pôs a cobra no pau grande: "Quero que você apanhe arara lá no pau para mim". Mas não era arara, era cobra. Então o avô dele perguntou: "O que seu irmão está falando [falou]?

\footnotetext{
${ }^{76}$ Trata-se do pau que, junto do poste de sustentação e a cada extremo da casa, serve para amarrar a rede de dormir.
} 
Você amanhã pega pau mole e quando a cobra morder, você pega no pescoço. "Ele enfiou o pedaço de pau no buraco. Quando a cobra pulou para morder, ele pegou pelo pescoço e puxou. Então ele tirou-a e levou lá e disse: "Toma, Kanarawari, sua arara"; Kanarawari, falou: "Eu pensei que era arara que estava lá dentro, que não era cobra, não.” Bom, aí arrancou o dente da cobra, Kanarawari, e fez yayap [escarificador].

E chamou o irmão para arranhar. O irmão falou: "Espera um bocadinho, vou lá em casa e depois volto." Foi lá dentro e falou com o avô. Era dente de cobra que o outro ia passar no corpo dele. O avô mandou que se enrolasse em casca de milho e outras coisas, para fingir que era seu corpo. Aí enrolou tudo no corpo, tudo mesmo, e quando acabou [de escarificar], disse: "Agora você vai morrer mesmo." De manhã Kanaratì levantou-se, chamou o irmão e perguntou: "Como saiu?" "Saiu bem mesmo. Eu arranhei muito bem você."

Passaram cinco dias e Kanarawari voltou a chamar o irmão e mandou-o arrancar jenipapo. Ele foi em casa, falar com o avô; ele disse-lhe o que fazer. E Kanarawari mandou-o, agora, ao lugar mais perigoso. Então o avô explicou que levasse Tarawi(n) [esquilo], Tsawarape [gambá?]. Aí foram, passaram linha no galho de jenipapo, para passarem por cima, a pé, para arrancar jenipapo. Para nadar pela lagoa, cheia de bichos bravos, não dava de ir não. Ninguém ia lá. Então Tarawi $(n)$ disse: "Agora você vai longe, que agora nós vamos brigar com esses bichos bravos. "(Era para sair de perto).

Aí pegaram um jenipapo e jogaram bem no meio da lagoa, e os bichos ficaram bravos. Os que queriam jenipapo estavam escondidos [no jenipapeiro], mas o rabo do Tsawarape estava fora, caía no lago. E o peixinho pequeno ia comer o rabo do Tsawarape. Como o peixe era pequeno, só tirava cabelo, por isso até hoje o rabo de Tsawarape é limpo, sem cabelo.

Chegaram de noite, com muito jenipapo. Quando ele foi tomar banho, Kanarawari, o irmão da mulher dele foi também, junto com ele e disse: "Olhe, seu irmão já chegou." "Não pode, ele já morreu, está na barriga da piranha." "Não, não está." ["Bobos, esses irmãos. Não se pode brigar com irmão, mas era por causa de mulher" - comenta o intérprete].

Dormiram três dias e chamou Kanaratì de novo: "Kanaratì, vem cá." "Espera aí, vou lá em casa, e volto." Aí falou: "Bom, amanhã você vai tirar para a gente folha de fumo para fumar. "Quando chegou em casa o avô perguntou: "Que seu irmão está falando?" "Mandou tirar fumo." "Se você for, você leva beija-flor, para tirar para você. Não pode chegar 
perto não, que é muito perigoso." Aí foram, ele, o avô, outros avós - um era o beija-flor. Chegaram lá. Tiraram um bocado de fumo, só o beija-flor [tirou]. Kanaratì ofereceu para o avô, ele aceitou, o outro também. Chegou de noite, com muito fumo. Aí Kanarati foi banhar com as mulheres do irmão.

Dois dias depois, chamou de novo. "Kanaratì, vem cá." "Espera aí, vou lá em casa e volto." [Cada vez que o avô aconselha o neto, por lhe temer a morte chora ritualmente; e o informante imita-o: "Ieremimino apa, ieremimino; ieremimino apa, ieremimino"]. Depois o irmão mandou-o ir buscar flechas. "Amanhã vou, bem cedo." O avô disse para levar um passarinho, Tsiwa'e(n), e outros passarinhos que não pode botar aí [isto é, escrever no caderno de campo], muito nome feio. Chegaram lá e os outros passarinhos foram tirar a flecha para ele. Tiraram cinco feixes de flechas. Então Tsiwa'e $(n)$ disse para Kanarati se afastar, que ele ia brigar com o bicho bravo que era o dono das flechas. Quando arrancaram as flechas, o bicho levantou logo, era fogo bravo que era o dono das flechas, Tata aruwiyap [fogo grande]. Em todos esses lugares havia um bicho para tomar conta das coisas. Quebraram flechas de novo e o bicho ficou bravo de novo $^{77}$.

Chegaram lá [de volta a casa] de noite também, e as mulheres falaram com ele. "Kanarawarì olhe, seu irmão já chegou." "Chegou o que, ele está morto, foi bicho bravo." De manhã cedo ele apareceu e deu muitas flechas para Kanarawari, mas escolheu as feias [para dar]. Ele também tinha raiva do irmão dele, porque o mandava no lugar bravo.

Passados cinco dias, aí foi lá, disse para ele ir na casa de Tupa $n)$ [trovão], para apanhar o machado dele para rachar lenha (o machado dele é quando relâmpago derruba pau para rachar). Yawaria foi com ele também, é a flecha de assobio. Aí chegou lá, estava só a mulher de Tupa $(n)$. "Meu marido não está, está na roça." Aí pegou o rapaz e escondeu-o no lugar onde não tinha perigo. O resto era tudo perigoso. Aí $[\operatorname{Tupa}(n)]$ chegou lá da roça e soltou aquele trovão, soltou, soltou, bravo mesmo. E a mulher dizia: "Olhe seu neto está aí." Mas ele não entendeu. Aí parou. Aí ela tirou-o do quarto, miritsi, e trouxe para fora. E Tupa $(n)$ disse: "Tenho ouvido que seu irmão tem raiva de você." Aí Tupa $(n)$ pediu-lhe para contar a história como foi. Aí Kanaratì disse: "Bom. É

\footnotetext{
77 O qualificativo tuwiyap (grande) aplica-se freqüentemente a uma entidade, quando se trata de um ser poderoso e mítico. Tata aruwiyap era o tutelar das flechas, seu "dono", e a razão disto percebe-se ao recordar o aparelho e o processo de obtenção do fogo, pois as flechas xinguanas são de cana de ubá ("flecha"). V. nota 56.
} 
verdade que quando vai namorando, você racha lenha para a mulher

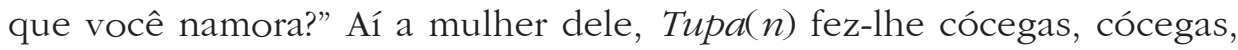
aí Tupa $(n)$ "morreu pouco" [perdeu os sentidos] e ela disse para o rapaz: "Agora você tem de tirar esses três machados que são mais fortes; aqueles não que são fracos. Os machados são os que fazem relâmpagos ${ }^{78}$. Ai Tupa(n) levantou e procurou: "Ah, é assim que está a história lá." "É sim, dizem que você fica rachando lenha para namoro." Aí a mulher fez-lhe cócegas de novo e ele morreu um pouquinho. E disse ao rapaz: "Agora você pode tirar." E o rapaz correu com aquele machado de Tupa(n) (que era pouco menor que a flauta de yakui), correu. Quando o rapaz foi mais longe, parou de correr. Aí Tupa(n) acordou: "Bom, conta mais história." A mulher disse que o rapaz já tinha ido. "Ah, agora ele está perto; não vai fugir; vai morrer." E mandou trovão mesmo. Quando Tupa(n) saiu fora, a flecha de assobio atirou-se sobre ele e Tupa(n) caiu. Aí a flecha de assobio chegou perto do rapaz e perguntou: "Não tem nada com você?" "Não, não tem nada, porque eu estava longe, já." Chegou de noite, lá, na casa do rapaz.

Então o avô disse: "Então chegou?" "Foi." Aí a mulher de Kanarawari disse: "Seu irmão chegou." "Que nada, está todo queimado".

Kanarati falou: "Kanarawari, é bom você ir, para conhecer; você está só mandando eu.” Mas se Kanarawari fosse, não voltava. Por isso não quis ir.

Aí passaram cinco dias e disse: "Bom, Kanaratì, vem cá. Amanhã você vai procurar nosso colar de concha." "Onde é?" "Na aldeia de Arakakuni( $n$ ) (índios bravos que comiam gente). Chegando em casa contou para o avô que o tinham mandado buscar mo' it [colar de cintura, de

\footnotetext{
${ }^{78}$ Levar lenha à casa de uma jovem é parte da corte. Hoje já quase não existem os machados de pedra, e os poucos subsistentes são guardados cuidadosamente. Informa Galvão (1963:126 n.6) que os têm enterrados no chão da casa, e que são de propriedade feminina. Seria possível terem tido um valor simbólico (além do prático), sexual talvez, dado que todo este mito parece girar em torno de um problema edipiano (v. a respeito Murphy \& Quain 1955:75-76, sobre a variante Trumaí), e tem uma estrutura nitidamente iniciática, podendo-se ligar aos rituais de iniciação pubertária. Haveria outra hipótese: o rapaz, submetido às provas, ao conquistar o machado instrumenta-se para a prestação de serviços ao sogro, representada pelo fornecimento de lenha. Não seria impossível combinar isto e o que se disse antes. Por outro lado, esta associação machado líticotrovão levanta a questão de se se trata de um empréstimo, de origem euro ou afro-brasileira: são bem conhecidas as crenças na pedra-de-raio $=$ machado polido, e as "pedras de Xangô" dos candomblés. Embora nos inclinemos a atribuir ao episódio mítico um fundo cultural indígena, e sejam parcas as evidências de aculturação na mitologia xinguana, temos de levar em conta a seguinte informação de nosso intérprete: "Quando o trovão cai, faz risquinho e na ponta deixa machado de pedra. Quem disse foi Caraíba, não foi Kamayurá não." A seguir, perguntou se isso era verdade, mas a dúvida incidia só sobre o que dissera, e não sobre o texto do mito.
} 
conchas $]^{79}$. "Acho que você não volta não. Lá é o lugar mais perigoso." Foram. Chegaram numa estrada bem lisa e perguntaram: "Como é que a gente vai chegar? Esses índios são muito bravos, comem gente. Deixa eu 'rezar', então", disse Kanaratì. Chegou bem à Aldeia e disse: "Vocês estão ainda aqui?" Aí saíram muitos que estavam dentro de casa. Aí chegaram lá, agarraram-no pelo braço, pelo pescoço, dizendo: "Este é meu." "Espera", disse o rapaz, "não é assim não. Tragam colares e amarrem no corpo todo e nos braços, pernas." E eles largaram-no e foram buscar. Acabaram de amarrar os colares e ele estava cheio de colares. "Bom, agora vocês saem de [perto de] mim e um vem de lá com borduna e me mata"80. Quando eles viraram as costas, Kanarati correu, correu com os índios bravos atrás, mas não conseguiram mais [apanhá-lo]. Pronto, correu: quando chegou bem longe, parou e tirou o colar do pescoço ${ }^{81}$, do cinto. Estavam com ele: "toco", iwīpibet; "dormência de pernas", myeay; "cãimbras", tryikapat. Foram esses que o ajudaram. Chegou de noite, cheio de mo'it.

Levantou-se no outro dia, foi tomar banho, e as duas mulheres foram banhar com ele - que era seu namorado. De manhã cedo escolheu o colar mais bonito e ficou com ele e o resto deu para o irmão dele: levou só colar fino, que não prestava não.

Passados cinco dias, o irmão chamou: "Amanhã você vai pedir kamitì [maracá] para a gente." "Bom, amanhã eu vou." O avô falou: "Bom você levar comida, gafanhoto, outro gafanhoto [isto é, doutra espécie].” Levou também pimenta para apanhar o kamitì na mão de $\operatorname{Moi}(n)$ [cobra], o bicho mais perigoso. Aí deu pimenta e quando $\operatorname{Moi}(n)$ comeu teve sono e dormiu. Então, quando a filha do $\operatorname{Moi}(n)$ estava dormindo e $\operatorname{Moi}(n)$ também, sua mulher foi tocando o kamitì e foi atrás da casa, entregando-o na mão de Kanaratì. A mulher disse então para o marido, mentindo: "Quebrou seu kamitì." O marido respondeu: "Então pode apanhar outro." Aí ela apanhou e voltou a dá-lo a

\footnotetext{
${ }^{79}$ Colar de discos de concha de caramujo. É manufatura de especialidade das tribos Karib da área. As mulheres usam-no como colar, mas os homens como cinto. A meio leva um cilindro de pedra perfurado (mo'ìkita: dizem que os "antigos" tinham muitos destes, "mas era muito caro para eles", o que deve ter relação com a inexistência de matéria-prima (rochas ígneas) na região. Afirmam que "cavam para achar os mo’ikita antigos" e que dessa forma os obtêm hoje. Simões (1967:139) recuperou duas destas contas em escavações no baixo Kuluene; conseguimos outras duas, sem perfurar, de um Kamayurá que as achara, numa abandonada aldeia Waurá às margens de Ipavu, à superfície.

${ }^{80} \mathrm{O}$ modo de sacrifício de um prisioneiro enfeitado, por antropófagos que escolhem sobre a vítima viva o bocado de que se hão de apropriar - "Este é meu!» -, assemelha-se notavelmente ao verificado entre os Tupinambá dos séculos XVI e XVII.

${ }^{81}$ Colar de placas retangulares de caramujo, ligeiramente côncavas, e sobrepostas. Mo'urape’i é sua forma normal, usada diariamente pelos homens; nas festas, e para adornar os Kwarìp, pode-se usar uma variante, montada sobre um arco de madeira e maior que o normal (mo'urape).
} 
Kanaratì Aí saíram da aldeia da cobra e ele ofereceu o kamiti para o gafanhoto, que aceitou e levou. Chegou de noite, no dia seguinte levantou: "Bom, Kanarawari, aqui está kamitì." "Como você foi lá?" "Fui."

Então Kanarawari encontrou o ninho do gavião Nyapakani(n) num pau bem alto. Fez escada e subiu lá. Aí chamou o irmão pau ir lá, tirar o gavião. "Eu fiz escada para chegar no gavião" 82 . "Bom, amanhã a gente vai." E dormiram primeiro. O avô dele estava chorando, sabendo que ele ia e não voltava mesmo. Mas ensinou: "Você mata rato e leva. Quando ele ficar podre, bem fedido, vai o Urubu, desce, apanha você e leva." Ele levou dez ratos, mais dez. E Kanarawari perguntou: "Para que você traz isso?" É para dar comida para o gavião.” Ele estava num jatobá grande, ita'i p. Aí ele pôs flecha no chão e subiu. Subiu. Quando chegou [lá em cima], o outro que estava no chão, tirou a escada. Aí Kanaratìi ficou olhando, dizendo: "Que é isso, rapaz, você não pode fazer coisas dessas!" Passou quatro dias lá em cima até o rato apodrecer.

Aí o İrivu [urubu] veio, veio, veio, chegou perto dele e disse: "Ôi, você tá aî? Eu soube que seu irmão está sempre com raiva de você." Era só um urubu, velho, mulher. Desceu e parou: "Espere ai um pouquinho, vou apanhar meu marido.” Foi lá, trouxe sal, pimenta, água para eles beberem, para comerem os ratos, os Urubus. Aí Kanarati ficou chamando: "Por aqui, por aqui, por aqui." O Urubu disse: "Ouço sempre dizer que seu irmão está com raiva de você." Aí o rapaz bebeu água, tomou banho e quando acabou, o Urubu comeu o rato podre; para comer o rato, tinha levado pimenta e sal. Aí disseram: "Agora você monta em cima da gente, não olha para baixo, nem se mexe, senão não volta mais. Você tem de ficar quieto." Montou. "Não abra os olhos, feche bem fechados, senão você fica com medo." Foi devagar, foi devagar, foi devagar, até que chegou lá no céu. Aí entrou lá e ele desceu: "Espera aí. Tem de descer com calma." Porque o Urubu tinha esporão grande na asa, se espetava o rapaz, matava-o. (O esporão era do tamanho dessa caneta).

Aí abriu o miritsi, ficou lá preso, tomou o remédio deles para ficar mais bonito, porque ele estava muito fraco ${ }^{83}$. A casa do urubu era fora da aldeia, fora dos outros pássaros lá do céu. Aí foram, toda a meninada, encostou-se na casa do urubu e perguntou: "Quem é que está aí preso, na casa do Urubu?" Foram e viram que era um rapaz que estava preso na casa

\footnotetext{
${ }^{82}$ Um pau fino, sobre o qual se cruzam a intervalos os degraus.

${ }^{83}$ O remédio do Urubu (İrìvu awa(n)ngì) é tomado pelos jovens em fase de reclusão pubertária. Numa variante (mito 21), o informante considerou o remédio como ponto focal do relato e contou a história de Kanaratì e Kanarawarì como a "História do remédio do Urubu". Destina-se a fortificar e fazer crescer.
} 
do Urubu. Tinha uma moça que encostou lá. O Urubu viu e disse que não podia entrar: "Sempre vocês falavam que minha casa era fedida." Aí o urubu ensinou: "Sempre que gavião [fêmea] passar aqui, você arranca rabo dele." O rapaz, então, arrancava e guardava no tuavi as penas dos bichos que passavam (antes ninguém pegava penas). Aí o pessoal soube que o rapaz estava arrancando penas, de arara e de gavião, e ficaram com raiva. Ele soube que o pessoal estava com raiva dele, porque arrancava muita pena de arara, gavião. Aí o Urubu combinou fazer pintura para o rapaz. Aí passaram jenipapo no corpo, fizeram jenipapo, fizeram tapaka, tudo de [tinta de] jenipapo. No outro dia, dançaram um bocado, fizeram festa, dança de mavurawa (que se dança no tempo da chuva, para piqui). A moça de Benokobori [curica] queria dançar com ele, também. Não a deixaram dançar. Os pássaros todos, gavião, arara, todos os pássaros, tinham raiva porque ele estava arrancando rabo de toda a moçada. "Mulher", disse o Urubu, "vamos levar [o rapaz] logo senão é capaz de brigarem aí, vão matar o rapaz." Depois o Urubu chamou o rapaz para pegar o tuavi das penas, para levar com ele.

Aí montou e eles ensinaram a não olhar para baixo. Foram, foram, até que desceram: "Espera um pouquinho, não desce rápido, deixa acalmar." Aí o rapaz desceu e o Urubu disse: "Quando você matar bicho, tira para fora da água, não deixa escondido, põe no seco, para [a gente] comer. Quando você matar o bicho, me chama, diz para mim onde está o bicho." (Os Kamayurá matam bicho e deixam no mato para ele, porque fez serviço bom.) Aí o Urubu ensinou o rapaz a fazer um bicho grande, bem grande mesmo, do tamanho da anta e parecido com anta, e pôs chifres em cima da cabeça para pegar o Kanarawari, o marido das mulheres. - "Não sei por que seu irmão tem raiva de você, não podia ficar com raiva."

O avô estava chorando. Aí o rapaz chegou lá na casa dele. Aí a mulher casada disse para Kanaratì: "Você já chegou?" Aí ele respondeu mal: "Vocês não podem mais falar comigo." Aí foi com avô deles, Mavutsini (n), no mato, fazer o bicho que o Urubu ensinou. Passaram todo o dia lá, trabalhando, só com aquele. Aí aprontou. Esconderam lá, bem escondido, e deixaram lá.

Aí o irmão disse: "Você já chegou?" "Cheguei." "Então pode vir aqui perto de mim fazer fecha, amanhã a gente vai caçar." Aí Kanaratì deu penas de fazer flecha para o irmão.

Entraram primeiro no mato, andaram tudo, não viram nada. Foram noutro mato, o rapaz fez gritaria, mas o bicho nem mexia; só mexia o rabo. Aí chegou lá e o rapaz mandou o bicho em cima do irmão dele: "Você não pode demorar!" O irmão estava esperando, e o bicho espetou- 
o bem no meio do peito. Kanarati mandou o bicho passar bem na frente da casa do irmão, "para eles verem como era bom o que fazia comigo." Aí passou perto da Aldeia. A mulher dele gritou, triste.

\section{0 - KANARATÌ E KANARAWARİ}

Outro história assim. História de Kamayurá. Kamayurá, mas não é não: outro Kamayurá. Outro Kamayurá. Mas ele fala diferente, mas esse Kamayurá não fala igual Kamayurá não ${ }^{84}$.

Esse Kamayurá chama Kanarati. Irmão mais novo chama Kanarawari ${ }^{85}$; então esse Kanarawari tem mulher. Kanarawari tem mulher. Kanarawari tem dois mulher. Então esse Kanaratì estava namorando com mulher do irmão. Estava namorando.

Aí esse Kanarati [Kanarawari] não acha bom [que o outro] namorava com mulher dele, não acha bom. Aí esse Kanaratì [Kanarawari] ficou assim, aí ele disse assim: "Como é que eu vou fazer com esse rapaz? Eu não estou achando bom assim, que está namorando minha mulher, não estou achando bom." Ficou achando ruim. Aí Kanarati [Kanarawari] pensou: "Bom, agora vou fazer cobra, aquele bicho mesmo que eu vou fazer." Aí, ele fez cobra. Fez cobra, então ele foi fazer cobra, lá [em] cima. Tem buriti

\footnotetext{
${ }^{84}$ Sobre a ocorrência dessa informação noutros contextos, v. índice: Kamayurá, Kamayurá antigos; Kamayurá de língua diferente, '̇(n)mawat. Dos cantos do Kawarip não se sabe ao certo - ou não quiseram informar - a tradução ao pé da letra, e atribuem isso a serem também numa língua antiga: dizem dever-se a diferença à aculturação e aos casamentos intertribais, que afastaram o Kamayurá atual desse Kamayurá antigo, "Kamayurá de verdade»; mas, contradizendo-se, afirmam igualmente que certas palavras dos cantos são Mehinaku, ou Waurá. Seria de suspeitar que se possa tratar ou de uma fase arcaica da língua que persiste no ritual, ou de letras tomadas de empréstimo a outras tribos, ou ainda de um vocabulário semelhante aos vocabulários xamânicos conhecidos em outras áreas. No caso especifico do İ(n)mawat, temos informes de que foi um grupo local, que se fundiu a outros para originar o atual. Há um indivíduo capaz de falar essa língua: trata-se de Bwabu, um dos maraka'ip (cantadores) do Kwarìp Kamayurá de 1965: mas ele próprio se afirmou incapaz de traduzir os cantos a que nos referimos. (V. nota 107)

85 É a única informação direta a respeito das relações de idade dos dois irmãos, mas cremo-la suspeita. De fato, como se verá na parte inicial da história, o inf. estava pouco seguro. E ser Kanarawarì o mais novo está em contradição com a trama do mito, em que um rapaz - adúltero - atravessa uma série de provas, da qual sai vencedor, que culmina com uma ascensão celeste e o tratamento mágico com o remédio do Urubu - o que interpretamos como correspondendo àquilo por que passa o adolescente em fase de iniciação. Vencidas as provas, o protagonista principal derrota e mata o irmão, e passa a ter acesso legítimo às suas mulheres. Tal como o adolescente que finda o período iniciático tem desde então acesso, com propósitos sexuais, às mulheres da tribo, mulheres essas antes controladas pelos adultos. Note-se também o desequilíbrio da situação: um irmão tem duas mulheres, o outro nenhuma - e luta por elas.
} 
seco, então ele faz buraco lá no meio, bem redondo: Então ele foi pôr cobra lá dentro, botar cobra. Assim, amanhã, assim hora [indica a altura do sol com a mão] ele chegou [voltou ${ }^{86}$.

Aí o irmão dele procurava: "Ô Kanarawarì, onde você estava hoje?" "Eu fui procurar, esse arara nova, para nós, para nós criar... "Sim. Tá bom." "Eu já encontrei essa arara nova. Amanhã você pode tirar para nós." "Sim, amanhã eu vou." Tem o avô dele, que sabe isso também.

Aí [Kanaratī] foi lá na casa. Aí avô dele procurava: "Como é que teu irmão falou para você?" "Ele disse que eu vou tirar arara nova para ele." "Olha, cuidado, hem! Aquele arara, que ele viu, não é não. Aquele é cobra que ele fez, lá." (Tem outro avô, também. ) "Você leva seu avô. Aí chega lá, seu avô ensina como é que tira cobra." "Sei." Amanhã cedo, saíram. Aí procurava: "Aonde fica essa arara nova?" "Você vai andando, eu marquei lá, você entra lá, tem arara novo lá." "Sim, pode deixar." Aí foi.

Aí ele viu, ele viu, buraco assim, bem feito. Aí ficou olhando assim. Aí... avô dele está aí [ao lado]; bom: "Você quebra pau seco, assim pedaço. Mete [no] buraco, antes [que] cobra morde, você pega cabeça." Aí ensinou. Aí ele quebrou pau; pau seco. Ele meteu esse vara, vara seco, aí cobra mordeu, aí esse rapaz pegou, pegou enrolando assim no braço. "Vam'bora." "Bom, você pode ir-se embora, eu fico por aí " [disse o avô].

Aí chegou lá. Aí, falou: "Kanarawarì, aqui seu arara!" Ele jogou assim, no meio, no sala. Aí mulher dele [de Kanarawari] ficou com medo, assim. Aí esse homem matou cobra: o irmão dele matou. Aí mulher dele falou para ele: "Você queria matar seu irmão, você mandou tirar esse cobra!" "Não é não, eu vi arara mesmo!" Bom. Ficou [dizendo] mentira: "Arara mesmo eu vi lá." Aí ele matou, tirou dente, aí ele fez, para riscar. Aí ele fez.

Aí ele chamou o irmão: "Kanaratì, vem cá. Eu já fez coisa para nós riscar." "Sim." "Amanhã à tarde, vamos riscar." "Tá bom." Aí ele foi. Aí avô dele procurava: "O que é que seu irmão disse para você?" "Ele disse que vai [me] arranhar amanhã." "Olha, cuidado, hem! Aquele não é dente de cachorra não; aquele é dente de cobra. Amanhã você vai morrer."

Aí amanhã à tarde, primeiro dia... Bom, ele chamou: "Vem cá. Agora vamos riscar." "Sim. Eu vou falar a meu avô primeiro." Aí foi [a] correr. Aí ele chegou lá: "Como é que eu vou fazer, hem, meu avô?" "Ah, bom. Faz assim: você tira casca de pau, põe aqui tudo no corpo." "Sim." Aí ele foi, e

\footnotetext{
${ }^{86}$ A contradição deste com o parágrafo anterior e o conhecimento de duas outras variantes do mito, permite reconhecer a troca de nomes, por engano do informante, neste local. Adiante, passam a figurar corretamente; entre colchetes, a forma certa.
} 
botou casca de pau, assim, tudo. Bom. Chegou lá. Bom. Ele riscava tudo. Tudinho mesmo. Aí esse irmão dele fala para ele [para Kanarawari]: "Você quer riscar também?" "Não, agora não. Só amanhã que eu risco. Você pode ir embora." Aí ele mandou ele embora. Aí o irmão dele falou: "Ele vai morrer hoje, de noite."

Mas ele não morre não. Chegou lá na casa, tirou todo aquele casca de pau. Depois o avô dele riscou, [com] dentinho de cachorra, tudo. Aí amanhã cedo, bem madrugada mesmo, foi tomar banho. Aí essa mulher foi atrás dele. Foi espiar esse rapaz. Aí esse irmão achou ruim, porque essa mulher foi atrás dele [do outro], então acha ruim. Bom. As mulheres disseram: "Nós foi hoje tomar banho, mais Kanaratì..." "Aquele não é Kanaratìnão, Kanarati já morreu. Aquele é avô dele." "Não é nada: Kanarati mesmo."

Aí amanhã cedo ele sentou assim, fora, aí o irmão falou: "Ih, rapaz, você não morreu não?!" "Eu não morreu não." Aí falou [consigo próprio]: "Ah, você está querendo me matar... Sim... Espera aí..." Aí ele não disse nada.

Aí ele, outro dia, ele foi mandado tirar jenipapo. O irmão dele chamou: "Amanhã cedo você vai tirar jenipapo para nós pintar." "Sim." Mas jenipapo fica lá no meio do lago. Mas tem bicho lá, dentro d'água, que come gente. Bom. Aí ele foi falar avô dele; [este disse]: "Você leva seu avô, (para nós chama Nyanuba(n) [aranha]). Você leva dois seu avô, Nyanuba(n).

De manhã cedo saiu, aí chega lá na casa de Nyanuba(n), ele falou: "Eu venho tirar jenipapo, eu venho falar você para tirar para mim." "Sim." "Então vamos embora." Aí foi lá. Aí ele encontrou jenipapo. Jenipapo lá bem no meio da lagoa. Tem bicho, lá dentro d'água, bicho que come gente. Bom: "Você pode ficar aqui, agora eu vou andar por cima d'água". Aí Nyanuba(n) foi andando por cima d'água, até subir, subindo, subindo,

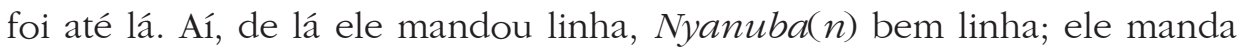
linha até lá no chão. Aí tem [outro] avô, chama Tarawi(n). Tarawi(n) subiu pendurando de linha, está subindo lá dentro do jenipapo. Foi tirar jenipapo muito, muito, muito, muito. Aí trouxeram muito jenipapo. "Agora você pode ficar lá, mais longe, agora eu vou atirar jenipapo lá dentro d'água." Aí esse avô dele tirava jenipapo, jogou assim dentro d'água, aí água subiu, subiu, subiu, subiu, até...: procurava esse rapaz. Mas esse Tarawi( $n$ ) enrolava com folha. Escondeu. Enrolava com folha, escondeu. (Lá em cima.) Aí esse bicho procurava lá, dentro de folha, não achava. Aí água baixou. Aí esse rapaz desceu. Aí: "Você pode ir embora, eu vou ficar por aí." [O avô ficou.]

Aí o rapaz chegou lá. Trouxeram muito jenipapo, aí amanhã cedo levou jenipapo para o irmão. Ele levou só um. Para ele [para si próprio], 
muito. Aí fizeram [tinta de] jenipapo. Aí ele diz: "Ih, rapaz, você não tira muito?!" "Não, eu tirei muito só para mim."

No outro dia foram [foi] procurar gavião. Gavião. Gavião novo. Gavião. Gavião novo. Aí esse rapaz entrou dentro do mato, aí ele encontrou gavião. Gavião novo. Bom: ele encontrou. Aí, este homem, ele faz pau para ele subir. Ele faz o pau lá. Ele bota pau assim junto, então ele coloca pau assim, outro assim em cima, aí vai, chega lá. Bom. Ele veio de lá, aí ele chegou lá [a casa]. Aí o irmão dele [Kanaratì] procurava: "Aonde você estava hoje?" "Eu fui caçar hoje, mas eu não encontrei nada, eu só encontrei gavião só. Novo. Agora, eu tenho de tirar, amanhã, para nós. Sim, amanhã eu vou tirar: você vai subindo." "Sim, tá bom. Amanhã vamos." Aí avô dele procurava: "Que é que seu irmão disse?" "Disse que ele viu gavião novo." "Olha, amanhã você não volta mais. Você vai ficar lá em cima mesmo. Você vai morrer lá em cima. Hoje de noite, você pega rato, você pega muito rato. Aí você leva lá em cima." "Sim." Aí pegou rato muito.

Amanhã ele foi. [Kanarawari falou:] "Bom, aqui tem gavião novo. Eu já fez pau para você subir." "Então vou subir." Aí [o outro] procurava: "Por que é que você trouxe esse rato?" "Não. . . Eu dá a esse gavião, está novo. Quando gavião novo está com fome, eu dou, para ele.” Ele disse. Aí foram subir; até chegar [ao] gavião. Ele chegou lá no gavião, aí irmão dele tirou esse pau, para ele não descer. Aí ficou lá, não voltou mais. Aí só homem chegou lá [a casa], aí a mulher dele procurava: "Cadê seu irmão?" "Eu deixou lá em cima." "Porque é que você deixou?" "Sabe porque é que eu deixei? Eu não estou gostando [ele] namorar com você. Por isso que eu deixei lá em cima, para ele morrer." Aí esse mulher chorou, por causa desse rapaz. Gostava dele. Aí o avô dele ficou chorando, ficou chorando assim... Está cuidando nele. . .

Aí passa dois dias lá em cima, aí esse rato apodreceu, não prestou mais. Ficou podre. Aí, meio-dia, Urubu vem. Vem chegando assim... Aí o Urubu vem perto de lá, aí esse rapaz mostrou esse rato podre. Aí esse Urubu vem assim, onde está ele. Aí ele falou, esse Urubu falou: "Para que seu irmão fez [com] você assim? Por que seu irmão ficou zangado com você?" "Porque ele. não acha bom [eu] namorar a mulher dele." Aí ele comeu rato, o Urubu. Comeu rato: "Bom, agora vou levar você, lá em cima, no céu." Diz que lá no céu. Bom. Comeu rato primeiro: "Bom, você pode ficar aqui pouquinho, agora vou buscar meu marido." Ai foi. Aí eles vem dois, esse Urubu.

Aí esse rapaz ficou magro, mesmo. Sem comer. Aí esse Urubu comeu esse rato: "Bom, agora vamos embora. Agora você pode subir aqui nas minhas costas." Aí esse rapaz subiu. "Você não olha no chão não. Você 
fecha seus olhos." Aí ele montou. Aí esse Urubu levou ele, lá em cima. Aí esse Urubu levou, esse rapaz. Diz que lá no céu. (Deve ser assim, não é?) Aí ele ficou lá, diz que ele viu a dança lá, a dança de kwarìp, diz que ele viu a dança de yawari, diz que ele viu dança de yakui; ele viu tudo, tudo lá, [o] que [se] dança.

Aí passa lá, muito dia mesmo, aí ele ganhou muito pena de gavião lá, pena de arara. Bom. Aí, esse Urubu veio trazer ele. Aí ele traz: "Agora vamos embora, aqui tem gavião, dois cabeças, está querendo comer você." Tem gavião, dois cabeças ${ }^{87}$.

Come gente. Dois cabeças. "Bom, agora eu vou levar você, senão aqui gavião te come." "Sim."

"Aí, amanhã cedo, eu vou pintar primeiro você, com jenipapo." Aí o Urubu pintou ele. Bem pintado. "Bom, agora vamos embora." Bem cedo mesmo, ele saiu de lá. Diz que esse céu é muito longe. Saiu de lá bem cedo, só voando, voando, voando, voando, voando, até chegar de noite, aqui no chão. "Bom, agora vou deixar você aqui, você pode matar aquele seu irmão. Bom, quando você pesca, quando você caça, quando você mata bicho, anta, você deixa para mim. Aí eu venho comer. Quando esse peixe, podre, você pode deixar para mim. Para mim comer", aí o Urubu conversou ele. "Viu, eu deixo. Quando eu caço por aí, eu mata bicho, eu deixo para você." "Tá bom. Então até logo, muito obrigado. Quando você chega lá [a casa], você faz um [boneco de] cera, igualzinho esse... boi. Você chega lá, você faz, [de] pau, faz aquele chifre, você faz lá, você mata seu irmão, com isso." "Sim." "Então até logo." Aí o urubu foi embora.

Aí esse rapaz veio. Aí bateu [à] porta, assim: "Abre a porta, meu avô." Aí avô veio abrir porta: "Ah, você veio, chegou..." "Cheguei. Muito bom lá, [o] que vi, tudo." "Eu já pensei que você não morre não. Eu já sabia que você não morre não." "Mas eu não morre não."

Aí, esse outro, o irmão dele, não sabia que ele chegou. Ele pensa que ele morreu. Aí amanhã bem madrugada mesmo, foi banhar. Foi banhar. "Bom, agora vamos banhar, Kanarati chegou...", [disseram as mulheres]. "Que Kanaratì nada, aquele é o avô dele... Kanaratì já morreu lá em cima", [Kanarawarì falou].

Aí foi, aí essa mulher falou: "Ih, Kanaratì. você chegou?" Aí, ele não respondeu não. Ficou assim, passou sem falar. Aí esse mulher ficou assim: "Ih, esse Kanarati está aborrecido com nós. Não sei porquê." Aí [ela] chegou lá, mulher chegou lá na casa: "Seu irmão chegou, hem!" "Chegou

\footnotetext{
${ }^{87}$ É o único exemplo de um gavião de duas cabeças; dada a insegurança do informante quanto a este mito, é possível ver aqui confusão com o urubu-rei de duas cabeças.
} 
nada! Morreu, muito tempo." Ele pensa que ele morre, mas não morre não. "É sim, Kanaratì. Nós falamos para ele - "Você chegou!", mas ele não respondeu nós. Ficou bravo."

Aí, amanhã cedo, ele chegou, irmão: "Ô... Kanarawarì, vem cá." "Ih, rapaz, você chegou?! Como é que você desceu lá de cima?" "Eu desceu mesmo", falou. Não diz [explica] nada: "Eu mesmo desceu." "Sim." "Eu cheguei lá..." - aí ele contou: "Eu fui lá no céu." Aí ele contou: "Eu vi muita dança lá, lá muito gente", ele contou. "Bom, agora nós vamos fazer flecha, muito mesmo. Quando termina esse flecha, vamos caçar para nós”, [Kanaratì falou]. "Sim, está bom."

Então ele fez flecha lá, prepararam lá flecha; bom, aí ele falou [Kanarawari]: "Que hora vamos sair amanhã, hem?" "Vamos sair amanhã cedo. Você come primeiro amanhã, depois vamos." Ele está mandando comer primeiro. Aí ele chegou lá [Kanaratì]. Aí foi falar à mulher dele [de Kanarawari] : "Você faz, beiju, peixe, kawi $(n)$, para o seu marido. Ele vai comer hoje, ele vai morrer hoje." "Sim." (Aí, esse mulher dele acha bom que ele morrer, viu?) "Você pode matar, esse meu marido!" "Eu mato, mesmo!" "Sim." Aí ele comeu beiju, peixe, lá, kawi(n), comeu tudo. Bom: "Vamos embora, senão nos não vamos encontrar nada." "Sim." Aí saíram.

Ele entrou dentro do mato. "Bom: você vai aqui, eu vou por aqui." "Sim." Aí o irmão dele foi assim. Ele, foi [por] aqui. Procurava, nada. Aí ele encontrou [encontraram-se]: "Encontrou alguma coisa? Viado, anta?" "Não, eu não encontrei nada." "Sim." "Vamos lá no outro [lugar]. Lá tem." Mas esse irmão (Kanaratī dele já fez, aquele... - parece o boi, não é? Ele fez. Mas está lá [no mato]. "Bom, aqui tem. Aqui vamos encontrar. Você vai ver." "Sim." Aí entraram. "Você pode ficar aqui, eu vou espantar para você, para você flechar; quando o bicho vim, você flecha." "Sim." Aí foi, foi andando devagarzinho, aí ele encontrou aquele que fez. Aí encontrou. Aí foi lá no perto dele, aí ele empurrou assim. Ele empurrou assim. Mandou para ele. Aí esse bicho foi correr, foi direto nele, furou barriga, aqui. Foi embora. Aí esse rapaz falou: "Você pode levar lá, perto de mulher dele, para ele [ela] ver." Aí esse bicho correu, até lá na casa dele. Aí mulher dele viu. "Ih! Agora? Marido?! Marido de nós morreu. Agora vamos casar irmão dele", aí mulher dele falou. Mulher falou que acha bom que ele morreu, ele (ela) acha bom.

Aí chegou lá. Aí o rapaz chegou lá: "Vocês acha ruim que eu matei seu marido?" "Não, nós não acha ruim não. Nós acha bom. Nós gosta [de você], mais do que [d]ele", aí mulher dele falou. Aí esse rapaz casou com os dois, mulher.

Aí acabou. 


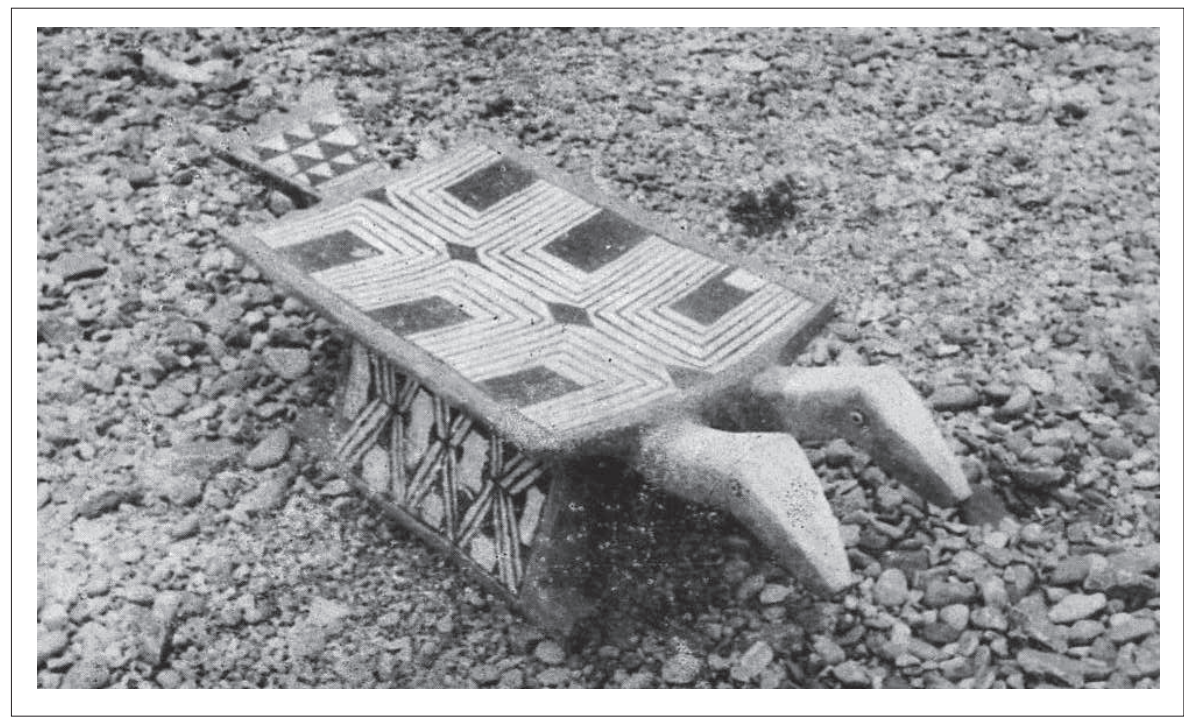

Estampa 2 - İrìutsing mokõy akãng: o Urubu-Rei de Duas Cabeças representado no banquinho cerimonial.

\section{1 - HISTÓRIA DO REMÉDIO DO URUBU}

Bom. Tinha Kanarawarì, tem irmão dele, chama Kanaratì ${ }^{88}$. Kanarawarì fez coisa de gavião, lá em cima do pau. Bom. Ele fez escada primeiro. Pronto. Depois ele ficou [falando ao] irmão dele: "Bom, Kanaratì, tem gavião, eu vi gavião, lá em cima. Mas eu quero que você vai tirar para mim." Falou isso. Bom. Depois ele foi entrar na casa dele, aí o avô dele perguntou: "O que Kanarawarì falou para você?" "Não... disse que o gavião, diz que eu vou tirar para ele." Aí o avô dele falou isso: "Mas você não vai voltar hoje, você vai morrer pra lá, você vai cair, você tem de pegar o rato. Tem de pegar muito rato." Aí o Kanaratì falou: "Tá bom."

Diz que ele pegou rato, tudo, cinco, seis, levou. "Vam'bora? "Vam'bora." E foi. Chegou lá perto dele: "Olha lá ele", ele mostrou. "Ih, pau grande..." Diz que é grande. "Bom, você vai subir." Fez a escada, Kanaratì diz que subiu. Subiu, chegou lá onde tem aquele coisa de gavião. Bom. Aí ele gritou, Kanarawarì gritou: Ô Kanaratì, você não vai cair agora, você vai morrer, você não vai cair [descer] mais." Ele pegou aquela escada, caiu tudo. Ficou lá em cima.

${ }^{88}$ Ao contrário dos demais informantes, este tomou como título o remédio do Urubu, e não o nome dos dois irmãos que disputam. Estava num período de liberdade entre reclusões sucessivas. Trata-se de Ayupu (v. Introdução). 
"Bom", Kanarati falou, "ah, você enganou, não sei o quê, vai morrer..." Falou isso. Pronto. Ficou dez dias, o rato vai fedendo. Vai feder. Então aquele Urubu escutou o cheiro e desceu, desceu aí o Kanarati chamou ele: "Ô avô, vem comer isso aqui, aqui tem seu comida: aqui para você." Desceu, diz que desceu: "Ih neto, você tá aí?" "Tou aqui." "Agora é que eu estou vendo você... Ih, e agora?" "Não sei, eu vou morrer aqui, ih... (não sei o que)." "Bom, eu vou levar você lá em minha casa." "Tá". "Então eu vou buscar meu mulher."

Diz que o Urubu foi ainda buscar a mulher dele, chegou lá, ele comeu aquele rato, tudo, pronto. Bom, então Kanaratì foi com ele, com aquele mulher do Urubu. Chegou lá, bom, diz que Kanaratì, ficou magrinho, quase morreu, ficou feio. Ficou mais quase dois meses [em cima do pau]. Bom, ele sentou nas costas do Urubu, saiu e levou na casa dele. Chegou lá: "Bom, você vai tomar meu remédio." Chama irìu awa(n)gì. Bom, ele foi buscar para ele, chegou lá, ele tomou, pronto. Mas ele ficou bonito, grande, homem grande. Ficou até não sei quanto, pode ser dez mês, ficou lá. Lá, no céu.

Depois, Nyapakani(n), o gavião entrou lá, quis namorar com ele, ele arrancou tudo o rabo para ele levar, outro gavião também entrou lá para namorar com ele, arrancou tudo pena. Chegou, aí o gavião viu, aquele pena de gavião não tinha nada mais. Aí ele pensou: "Quem que está tirando o rabo de nosso mulher?" Falou. "Não sei, acho que aqui, na casa do Urubu já tem gente." Bom, aí ele [quer] comer ele: "Nós vamos matar ele." Aí o Urubu escutou isso. Chegou lá para o Kanaratì: "Bom, eu vou levar você, esse pessoal está querendo comer você." "Então está bom."

Bom, um dia, bem cedo, aí ele desceu com ele. Pronto, mulher dele, e o marido, Urubu. Aí vem, vem, vem, diz que ele desceu lá na aldeia dele, chegou lá. Aí o avô dele estava chorando, o avô de Kanaratì. Chegou. Pronto. Aí chegou no avô dele, o avô dele disse: "lh!... você já vem, não morreu não..." Aí pronto.

Dormiu. O irmão dele, ele não viu, ainda. Bom, ele foi tomar banho, bem cedo. Foi, vai assobiando assim, assobiando, aí a mulher de Kanarawari escutou: "Ah, Kanarati chegou, vou tomar banho com ele." Aí Kanarawari falou: "Uai, vai com ele, já morreu, Kanaratì já morreu, caiu, morreu, não vem mais..." Foi embora. Chegou, a mulher dele contou para ele: "Kanaratì chegou, está gordo..." "Que nada, Kanaratì já morreu. Como é que ele desceu?" "Não sei não." "Ah, aquele Kanaratì já morreu, não vem mais, deixa pra lá." Pronto.

Amanheceu. De manhã cedo, ele chamou: "Kanarawarì, vem cá. Eu vou conversar com você." Chegou. "Ah! Você chegou, rapaz?" "Eu cheguei." "Puxa, como é que você chegou?" "Mas eu desceu. Quando 
você saiu, desceu." "É?" Disse: "É. Vamos fazer flecha?" "Vam’bora." Aí diz que ele fez muito flecha. "Amanhã vamos caçar, matar bicho..." "Tá okey" [sic]. Pronto.

Amanhã, Kanaratì foi fazer ubuku (aquele chefe, digo, como é que se chama eu não sei, ubuku. E o viado grande, aquele que tem o chifre. [Cervo?] É, cervo. [Como é que você chama?] Ubuku.) Kanaratì fez, fez bem. Fez embira, fez bem direito, igual ele. Pronto. Aí ele, Kanaratì: "Tá conversando com você. Se Kanarawarì vem para cá, você corre, pode furar ele." Ele falou, falou bem direito: "Kanarawarì quer matar eu, então eu vou matar ele, tá bem?" "Tá." "Bom, vou embora."

Dormiu. De manhã cedo: Kanarawarì, vamos caçar? Vamos embora?" Diz que saiu. Chegou lá no mato: "Bom, você vai ficar aqui, Kanarawarì. Eu vou rodear esse mato aí, prá correr bicho para você matar aqui." "Tá." Aí ele chegou lá, foi lá, nada. Depois foi no outro [lugar], nada. Depois foi no outro, já tem o ubuku: "Bom, fica aqui, quando ele vem aqui, você vai matar. "Tá bom." Aí foi embora. E vai procurando, chegou até no ubuku: "Vai logo, rapaz, corre!" Aí o ubuku não quer correr. "Vai logo!" Que ele bateu, diz que na ponta, aí correu. "Correu, Kanarawarì, já vai correndo, pode matar esse ubuku!" Depois eles levaram, diz que pegou bem aqui [indica com a mão espalmada o meio do peito], é, Kanarawari morreu. Aí o Kanaratì falou: "Pode levar longe... Prá lá, prá lá onde tem caraíba [branco]. Pronto, levou, chegou lá, passou na aldeia dele. Aí mulher dele disse que viu: "Ih, Kanarawari morreu... Bicho matou ele..." Pronto. Foi embora. Só.

\section{2 - COMO O URUBU ARRANJOU JENIPAPO}

Urubu foi lá no Pakue $(n)^{89}$, foi visita, no Pakue(n). Urubu foi lá onde está Pakue(n), foi [fazer] visita. Então o Urubu chegou lá, Urubu viu o jenipapo, aí Urubu viu, esse jenipapo, então esse Urubu falou para o Pakue(n): "Ô Pakue (n), você quer me arranjar um pouquinho do jenipapo?" "Sim. Eu arranjo."

Depois o Pakue( $n)$ foi falar ao peixe, peixe, mas Pakue(n) não é dono do jenipapo não. Quem é dono do jenipapo [é o] peixe. (O... Você já

\footnotetext{
${ }^{89}$ Pakue (n) ("Gaivota") é um ser que mora embaixo d'água, e deu também a mandioca aos Kamayurá. Obérg (1953:19) diz que Pakue(n) (Pakoin) foi feito de uma cabaça a que Mavutsini(n) (Mavutsiné) pôs uma pena de cada lado, cobrando vida quando o herói soprou fumaça sobre ela. Isto, para que desse a mandioca aos Kamayurá.
} 
viu assim, o "pintado"? É dele.) Então o Pakue( $n$ ) foi lá. Está lá o peixe. (Quem é o chefe do peixe é, diz que é "Matrinchã".) Aí o Pakue( $n$ ) foi falar Ipiyawo, o chefe do peixe. Então Ipiyawo arranjou para ele. Depois o Pakue $(n)$ fez para o Urubu, mas ele não deu aquele muda, deu tinta (tinta feita), então Pakue( $n$ ) deu para ele.

Aí Urubu passou lá três dias. Aí Urubu procurava: "Como é que vocês pinta, com isso?" Então o Pakue $(n)$ mostrou para ele: "Nós pinta assim." Ele chamou um rapaz, o Pakue $(n)$ chamou rapaz, então o Pakue $(n)$ estava pintando o rapaz, lá, aí o Urubu ficava olhando, como é que ele pinta, assim pintado.

Aí esse Urubu, foi embora, de lá. Lá, por dentro d'água, peixe fica como assim, água só fica em cima. No alto ${ }^{90}$. Então Urubu foi embora. Foi embora. Aí Pakue(n) levou ele. Bom: "Agora eu vou levar você, senão você perde [-se por] lá. Você não vai mais sair daqui." Aí levou ela; aí saiu, de dentro d'água, saiu. Aí ele [a água] fechou. "Bom: Você pode ir embora." Aí Pakue $(n)$ voltou, ai Urubu foi embora. Subiu, lá no céu.

Aí o Urubu chegou lá, aí ele contava: "Eu já vi como o Pakue(n) pintava com isso. Agora vamos pintar como ele. Eu já vi." Aí ele chamou uma moça, aí ele pintou. Urubu pintou. Bom. O Pakue(n) deu jenipapo assim, bem assim: tem um cabaço assim, bem cheio, feito [isto é, com tinta feita]. Aí ele levou, aí ele chegou lá [o Urubu], aí ele contou: "Já viu lá, jenipapo. Já viu tudo.”

Depois, o Pakue (n) arrancava o muda de jenipapo, aí ele levou lá, no Kamayurá, aí Pakue(n) plantou, lá. Aí a mulher do Pakue(n) procurava91: "O que é isso?" "Esse é jenipapo." Então jenipapo nasceu, cresceu assim, ficou esse tamanho. Deu muito fruta. Aí Pakue $n$ ) disse para a mulher: "Esse, jenipapo. [Para] você se pintar, você tira fruta, você tira casca, mistura com água.” Aí Pakue(n) ensinou.

Aí depois o Urubu vem outra vez, la no Pakue( $n)$, e veio pedir muda. Mas Pakue( $n$ ) não deu; aí Pakue $(n)$ disse para ele: "Você leva muda, você planta lá, não nasce, não.” Diz que lá no céu, muito quente ${ }^{92}$. Aí depois o Urubu veio embora.

Aí Urubu pintou aquele homem que foi lá no céu. Aí então, esse homem [que] foi lá no céu, ele viu como é que pintou. Então esse homem vem lá no Kamayurá, ele pintou igual. Aí os outros aprendeu.

Era assim.

\footnotetext{
${ }^{90}$ Sobre a concepção e crenças ligadas à água, v. Índice, Água.

${ }^{91}$ Ela era Kamayurá. V. mito 24.

92 No céu não há mato, tudo é limpo (mito 17). Essa seria a explicação.
} 


\section{3 - COMO O URUBU FICOU PRETO}

Urubu foi brigar. [Com] outro gavião. Outro gavião bravo. (Chama Pipiwa [esse gavião].) Foi brigar. Então Urubu chegou lá perto de aldeia de Pipiwa, então ele passa carvão. Passa carvão tudo. Mas não tem jenipapo para ele. Não tem urucu, não tem nada. Então ele pegou carvão, passa no corpo tudo ${ }^{93}$. Tem terra vermelho, então ele passa na cara, para ficar vermelho. Aí ele ficou vermelho, o corpo dele ficou preto.

Aí esse Pipiwa tem outro jenipapo, não é jenipapo não (eu não me lembro o nome). Então esse Pipiwa estava pintando. O pessoal dele estava pintando, mas outro já foi contar para [ele que] Urubu vai brigar com ele. Então esse Pipiwa estava pintando, esperando. Aí Urubu chegou lá, na aldeia do Pipiwa, aí Pipiwa viu assim, aí Pipiwa pensava [que era] o pau; pau queimado. Aí ele ficou assim preto, tudo preto.

Aí depois o Urubu briga lá, aí Urubu ganhou muito, essa briga. Mas esse gavião bravo [era] muito, mas não ganhou não. ([O Urubu] tem o pessoal dele, também; o pessoal dele foi com ele também.) Então esse Pipiwa estava esperando. Pipiwa estava assim, muito, agora o Urubu foi, [com] dez pessoal, ele levou o pessoal dele. Só dez. Mas o Urubu ganhou. Mas esse Pipiwa não sabe essa briga; aí Urubu mataram um bocado. Muito mesmo. O pessoal do Urubu, não morreu nem um. Aí Urubu voltou.

Aí ele chega lá na aldeia dele, aí foi tirar esse carvão, mas não saiu não. Aí ele, o Urubu, ficou assim, ficou preto.

\section{4 - ORIGEM DA MANDIOCA}

Tem esse índio que se chama Pakue(n) [gaivota]. Esse Pakue(n) ele mora dentro d'água. Pakue $(n)$ apareceu na aldeia de outro índio. Esse índio não tem o que comer: beiju, mandioca; quem tem é Pakue( $n)$. Pakue $(n)$ na aldeia viu uma moça e casou com ela. Ele, com vontade de comer beiju, estava lá há mais de cinco dias, pediu à mulher o que tinha para comer. Ela não tinha nada Pakue $n$ ) convidou a mulher para a terra dele, para ver como é beiju. Pukue( $n$ ) falou: "Já vi que vocês não comem nada, nem beiju, nem peixe; vamos para minha terra." O outro índio [da aldeia da mulher de Pakue( $n)$ ] bebe só a água de uma raiz.

\footnotetext{
${ }^{93}$ O corpo todo pintado de negro com fuligem, e cocares de penas escuras na cabeça, são os atavios de guerra Kamayurá. Os cocares diferentes dos de festa são, dizem, para confundir os inimigos, quanto à identidade do grupo atacante, no caso de se perder algum cocar. A pintura do Urubu também servia de camuflagem. Trata-se do Urubu comum, preto.
} 
Pakue( $n$ ) saiu de lá, ele e a mulher foram buscar beiju. Pakue( $n$ ) e a mulher chegaram à beira da água; ele disse para irem para dentro d'água; ela ficou com medo. Aí foram dentro d'água, onde havia uma casa grande. A mãe de Pakue( $n$ ) estava muito alegre porque Pakue( $n$ ) casou. Ela mostrou beiju, peixe assado e cozido, a mulher comeu lá; no outro dia voltaram com beiju. Vieram para casa da mulher. A mulher mostrou tudo e contou. Pakue $(n)$ resolveu fazer roça.

Pakue $(n)$ fez roça, como daqui lá no aeroporto ${ }^{94}$. Fez roça grande. Plantou. O pessoal de Pakue $(n)$ veio, plantou para ele. Depois nasceu muita mandioca, ficou bom para ele comer. Mulher de Pakue(n), o pai dela achou bom Pakue( $n$ ) arranjar beiju e mandioca.

A cunhada deles ficava em casa e não saía. Moça nova. A mulher de Pakue $(n)$ disse para ele não "mexer" com a irmã, que a mãe ficava brava. Todo dia iam arrancar mandioca, todo dia. Depois ele ficou doente, só conversa dele, mentira. Ficou em casa só, e tentou "conversar" a moça; quando a mãe chegou, ela estava "boa" ainda. No outro dia Pakue(n) tomou a ficar em casa. Tomou a mexer com a moça. Ela disse que ia tirar a liga (que usam abaixo do joelho para engrossar a perna, para bonito). Pakue $(n)$ "trabalhou" ela. O pai da moça fez cesto para ela ficar dentro. Ela entrou, mas não conseguiu entrar direito. (A moça não podia ficar dentro da cesta, e por isso a mãe descobriu que ela tinha tido relações; ela não coube na cesta pendurada do teto porque tivera as relações sem tirar as ligas. Ainda hoje, homem ou mulher, que o fizer, de ligas postas, fica sem poder andar direito.) Ficou com medo do pai e da mãe. A mãe dela chegou e achou ruim, ficou brava com Pakue(n), muito mesmo; mandou ele embora. Ele foi embora, foi chamar o pessoal dele para arrancar toda a mandioca.

Ele contou o que aconteceu, todos arrancaram a mandioca, toda. Pakue $(n)$ voltou para esconder três ramas para a mulher dele, que já estava "buchada". Ele disse que ia embora, e disse que a rama estava escondida: para quando o filho nascer, o pai da mulher plantar; ela encontrou a rama de mandioca. O pai dela plantou. A mandioca nasceu, devagarzinho, fez roça, depois outra e assim foi aumentando. Nasceu muita mandioca ${ }^{95}$.

\footnotetext{
${ }^{94} \mathrm{O}$ informante achava-se em Brasília quando nos contou os mitos 24 e 25. A distância da Universidade ao Aeroporto é de uns $15 \mathrm{~km}$ em linha reta.

${ }^{55}$ Schultz e Chiara (1967) observaram rituais ligados às pás de beiju nos Waurá. Estas são simples ou zoomorfas, destacando-se as ornitomorfas entre os Kamayurá. Haveria uma possibilidade de se ligar a pá de beiju (iwep) em forma de pássaro, a Pakue(n); mas isto por enquanto não passa de hipótese. No decorrer das cerimônias observadas por Schultz, quando os homens voltam à aldeia com a madeira para fazer as pás, são recebidos por três mulheres que "cantam e dançam. Uma delas usa um
} 


\section{5 - ORIGEM DO PIQUI}

Antigos não tinham piqui. Katipo era mulher casada, e namorava um jacaré. Ela foi para a roça. O marido dela tinha duas mulheres. O marido ficou. Ela fez beiju para o jacaré e levou; ele era muito bonito.

A mulher encontrou-o e gostou dele; por ser bonito, namorou. O homem não soube e todo dia a mulher levava-lhe beiju quando ia para a roça.

A mulher foi para a roça de novo, fez beiju; o marido perguntou para que era o beiju: "Para comer com gafanhoto ${ }^{96}$ e não passar fome na roça." Ela perguntou: "Você não vai?". O homem disse: "Só depois." Ela foi e o jacaré esperava na estrada. O marido foi atrás e viu-a namorando o jacaré. $\mathrm{O}$ homem passou; a mulher ficou namorando e não viu o homem. $\mathrm{O}$ homem chegou na roça, a mulher não estava. Ficou capinando, quando a mulher chegou.

O homem perguntou: "Você não estava trabalhando aqui na roça? Onde foi?" A mulher respondeu: "No mato para apanhar gafanhoto para comer."

Aí saíram de lá e foram para casa. Quando chegaram o homem disse: "Vou trabalhar flecha. amanhã vou caçar" (a mulher não sabia). A mulher disse: "Amanhã vou fazer beiju para levar." O homem se calou.

De manhã ela fez beiju. O homem saiu bem cedo: "Vou caçar." Foi esperar o jacaré. Ela foi, atrás, levando beiju e kawi(n) para o jacaré.

Quando a mulher chegou o jacaré não estava na casa dele. Ela chamou, gritando. Aí jacaré saiu. A mulher disse: "Vem comer o seu beiju; eu trouxe beiju bom para você." O homem olhava o jacaré. O jacaré veio.

Jacaré veio, ficou conversando. Abraçando primeiro uma, depois a outra (eram as duas mulheres do homem que namoravam o jacaré). O jacaré era um rapaz bonito. O homem esperava ele começar a "trabalhar."

cinturão largo, ornamento tipicamente masculino, mas sua pintura é em vermelho, sem desenhos, pintura característica das mulheres. Nas mãos, com os braços esticados, ela segura uma corda». Esta corda poderia, cremos, corresponder simbolicamente à corda (guarnecida por pedras cortantes) usada por Pakue(n) para derrubar as árvores de sua roça (Oberg 1953:19). Haveria ainda outra hipótese, inverificável de momento, por falta de documento fotográfico em Schultz: a de que não se trate de "corda" propriamente dita, mas da meada de fios de algodão frouxamente torcida, que usam as mulheres como jarreteira - o que se ligaria ao ato de a cunhada tirar as jarreteiras para ter relações sexuais. Ainda em relação à pá, Oberg (1953:18-20) dá como mama'e(n) da mandioca: ihít, iwép-ivét (pá-de-beiju) e ivirat (pau-de-cavar). Nas cerimônias vistas por Schultz, os paus-de-cavar (que perderam sua função prática) também entram. Por nossa parte, anotamos entre os Kamayurá dois tipos de pintura aplicada aos Kwarìp: iwep (pá-de-beiju) e iwepi(n) (pazinha-de-beiju). Ainda não estudamos suficientemente o problema, o que impede ir, por agora, além destas simples aproximações.

${ }^{96}$ Entre os Kuikúro, os grandes gafanhotos que aparecem em certa época do ano são guloseima muito apreciada, mas não se podem considerar fator importante na dieta. Ainda não observamos seu consumo pelos Kamayurá. 
Jacaré comeu beiju. A mulher convidou-o a "trabalhar": primeiro uma, depois a outra. Quando jacaré trabalhou a segunda, o homem flechou, matando-o. Depois, bateu nas mulheres muito com um pau, no corpo todo. As mulheres choravam97. Aí o homem deixou-as lá: "Ficam aqui, não podem ficar lá na casa.”

A segunda mulher disse para a outra: "Que é que vamos fazer com o jacaré? Enterrar ou queimar?" "Queimar; não pode enterrar." Foi buscar fogo na roça, juntaram capim sobre ele e queimaram o jacaré, deixando-o queimado.

Foram para casa, apanharam de novo e ficaram três dias sem comer, por causa do que fizeram. "Vocês não podem fazer beiju. Eu não como se fizerem." Ele não pescava, comia na casa dos outros.

Ele largou as mulheres, elas ficaram sozinhas. Cinco dias depois, elas foram olhar o jacaré queimado. "Vamos ver se ele nasce?" Chegaram lá.

O piqui nasceu da cinza do jacaré. Ficaram alegres por ele ter nascido. Discutiram sobre o nome. "Vamos botar nome agora, Piqui."

As mulheres saíram de onde era a casa do marido, fizeram casa junto do piqui, esperando a fruta nascer. Quando nasceu e ficou maduro, piqui caiu da árvore. Pegaram e cortaram o piqui com um caramujo. Cheiraram: "Não tem cheiro. Como vamos fazer agora?" Não fizeram nada. Caiu muito piqui; elas trabalhavam-no muito, cortando, [etc.].

Um homem, Murenayat, que morava em Murena [ele pusera o nome a si próprio - "dono de Murena"], tinha um papagaio que falava a língua de Murenayat, que era Kamayurá. As mulheres moravam longe de Murena, como daqui no aeroporto $^{98}$. Elas estavam trabalhando o piqui, que nasceu de quatro cores diferentes, conforme a direção dos ramos [norte, azul; sul, verde; leste, branco; oeste, vermelho] ${ }^{99}$. O papagaio comia só fruta. Murenayat e o papagaio não conheciam piqui.

\footnotetext{
${ }^{97}$ Se as normas de convivência, valorizando o comportamento não conflituoso entre indivíduos de uma mesma tribo, proscrevem represálias contra o ofensor masculino em caso de adultério, não impedem o castigo físico da mulher pelo marido. Ou que a mulher o agrida oral ou até pessoalmente, se foi este o implicado. V. mito 12.

${ }^{98}$ V. nota 94.

${ }^{99}$ A árvore que nasce da morte e das cinzas do jacaré (mais precisamente, segundo outros informes, de seus testículos), da qual os ramos têm frutos cuja cor varia com os pontos cardeais, e que recebem seu cheiro dos órgãos sexuais femininos, tem todas as características de uma Árvore Cósmica e da Vida. Cresceu perto de Murena, centro do mundo. E acredita-se ser o piqui fruta afrodisíaca e que facilita a concepção. No Kwarìp, uma moça que finaliza a iniciação pubertária distribui aos chefes visitantes castanha de piqui, e dá-lhes suas ligas, em simbólica oferta das mulheres da tribo hospedeira (Agostinho 1966:60).
} 
Papagaio saiu cedo, foi comer fruta, uma qualquer; no dia seguinte, de novo; no terceiro dia, achou piqui e comeu piqui: quando ele encheu o papo, tirou o fruto e foi mostrar a Murenayat. Ele estava lá, sentado. O papagaio ficou trepado na casa, descascando piqui; deixou cair um pedaço e Murenayat ficou olhando, sem saber o que era. "Onde você arranjou essa fruta?" Cheirou, não tinha cheiro.

Murenayat arrumou linha. Foi trocar com um homem, Nyanuba(n)

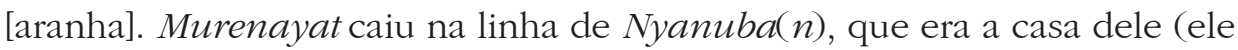
fazia rede de pescar). Nyanuba(n) chegou, olhou Murenayat e disse: "Você caiu na minha casa, vou comer você." "Não, você não come eu; eu não sei entrar em sua casa, vim comprar linha." Nyanuba(n) deu-lhe linha.

Murenayat atou a linha à perna do papagaio. O papagaio de manhã voou, foi onde estava o piqui e Murenayat seguiu a linha, vendo-a no alto das árvores. Achou piqui. Murenayat viu as mulheres e elas viram e souberam que eles vinham. Ele perguntou-Ihes o que faziam.

Murenayat perguntou: "Como plantam isso?" Elas contaram: "Piqui, é feito de jacaré." Murenayat perguntou: "Esse piqui tem cheiro?" "Não." Murenayat: "Então vou fazer cheiro de piqui."

Murenayat deitou-se, atravessado na porta. As mulheres passaram sobre as pernas dele. Murenayat pegava o piqui e, quando elas abriam as pernas ao passar sobre ele, passava-lhes o piqui no ta(n)ma [órgãos sexuais femininos], pegando o cheiro. Então, passou esse piqui na árvore para passar o cheiro. Quando piqui vermelho caiu, mandou cheirar. As mulheres cheiraram. Depois caíram piqui branco, azul, verde. Todos cheiravam. Aí ele passou o piqui vermelho nos outros, depois todos os piquis ficaram vermelhos.

Cheiro de $\operatorname{ta}(n) m a$ antigo era cheiro de piqui. Kamayurá "trabalhava" muito mulher; quem chegava perto sentia, ficava sabendo. Aí Murenayat passou esse cheiro no piqui e a mulher não tinha mais cheiro. As mulheres sabiam o que fazia o marido [infidelidades] pelo cheiro - por isso Murenayat mudou o cheiro.

Murenayat plantou muito piqui em Murena, e os Kamayurá foram apanhar piqui, muda, e levaram lá para o Kamayurá [aldeia], nascendo muito piqui.

\section{6 - HISTÓRIA DE YAKUI}

Bom, história assim, como é que foi [que] nasceu yakui ${ }^{100}$. Ayanama foi pescar. Esse o nome do índio, Ayanama. Ayanama foi pescar; foi

\footnotetext{
${ }^{100}$ Yakui são as flautas tabuadas às mulheres e guardadas numa casinha especial, Tapwi(n), no centro da aldeia. Mas o que Ayanama captura não é propriamente uma flauta, mas algo de material ignorado - como o são as "coisas de mama'e(n) (taa(n)ngap, p. ex.) dadas por estes aos pajés em testemunho de seus contatos.
} 
tampar peixe. Primeiro Ayanama fez urna rede para pegar peixe (para nós chama a rede, pia). Ayanama faz primeiro pia, depois ele vai pegar peixe, mas ele vai pescar só de noite. Então ele chega lá, de tarde, ele faz jirau, para ele ficar lá em cima. Bom. Então Ayanama está deitando pia por dentro d’água; ele amarra a canoa dele por baixo [do] jirau. Então ele pegava muito peixe, muito, muito, mesmo. Pegava pintado, pegava tucunaré, pegava pirarara, pegava bicuda, pegava surubi, pegava muito.

Aí Ayanama desceu do jirau. Ayanama está botando água por dentro do canoa dele, botaram água. Depois ele pegava jacuí, enrolava com pia; aí ele botou dentro canoa. Aí Ayanama ele conheceu logo, jacuí. Botou nome mesmo, jacuí. Aí Ayanama ficou assim, pensando, agora, Ayanama falando: "Esse jacuí agora, só não pode ver, mulher. Mulher não pode ver agora. Só homem agora só pode ver." Bom. Depois Ayanama foi embora. Chegou lá na estrada dele, aí ele pegou o capim, para enrolar jacuí. Bem enrolado, para não ver. Aí ele chegou lá na casa. Aí ele contou, para a mulher: 'Eu já peguei, jacuí. Jacuí mesmo. Jacuí bem feito. Só você não pode ver. Agora... homem só pode ver jacuí. Homem pode, mulher não pode ver jacuí."

Bom. Amanhã Ayanama foi tirar madeira, para fazer jacuí. Outro madeira. Agora, aquele que ele pegou [na água], não é madeira. Não é pau, não é nada qualquer coisa. Ayanama faz madeira, igualzinho jacuí. Ele faz quatro jacuí. Aí Ayanama estava tocando lá.

Tem um amigo, lá em Ay anama; chama Mawani( $n)$-wani( $n)$. Amigo dele chama Mawani( $n)$-wani $(n)^{101}$. Então esse amigo dele ouviu ele tocar. Ayanama morava assim. Agora, amigo dele, morava como na casa lá do lado. Aí Ayanama tocava, aí amigo dele viu tocar. Aí amigo dele falou assim: "O que Ayanama estava tocando lá? Bom. Amanhã eu vou lá onde ele está, eu vou ver o que é que ele toca, lá.” Aí amanhã foi, amigo dele chegou. Aí Ayanama viu: "Ah, você está aí, amigo!" "Estou aqui." Aí ele procurou: "O que é que você tocou por aí, hem, Ayanama?" "Não... Eu toquei aqui... Eu fez pau para mim dançar, jacuí. Eu fez jacuí aqui para mim tocar." Aí amigo dele acha bom: "Eu acho bom aquilo você tocou. Aquele que você tocou você vai me dar para mim." "Sim, eu dou. Quando você vai embora, eu dou para você. " Aí ele deu para ele. Mas aquele que ele pegou, estava escondido, mas não mostrou para ele. Ele enrolou aquele que pegou, escondeu. Aí foi embora [o amigo].

\footnotetext{
101 Sego Oberg (1953:50), Mavutsiné fez os Kamayurá de kamiuwa: primeiro Kanarawarí, Kanaratí e duas mulheres. Depois Yanamá e Vanivaní. Yanamá morava em Murena e Vanivaní em vanivaní. Sego Murphy \& Quain, $\operatorname{Wani}(n) \operatorname{wani}(n)$ era: a) o nome de um ser mítico; b) a aldeia celeste onde mora esse ser; c) o local de uma antiga aldeia Trumaí. Isto explicaria por que a "língua de Ayanama - companheiro de Mawani(n) -wani(n) - era Trumaí" (mito 33; o parêntese é nosso).
} 
Aí amigo ficava tocando lá. Bom. Aí Ayanama pegou aquele que ele pegou, vai tocar. Ele toca só de noite. Ele toca. Aí amigo dele viu tocar também: "Ih, aquele mais bom! Amanhã eu vou pedir para mim." Amanhã ele chegou de novo: "Aquele que você tocou, mais bonito [do que] aquilo que você me deu!" "Não, aquele está bom também...", vai ficando mentindo para ele, "aquele também muito bom. Aquele que eu fiquei tocando, não presta. Quer ver? Eu vou mostrar para você.” (Ele fez muito jacuí primeiro; muito mesmo.) "Aí, este aqui toquei. Este aqui toquei, esta noite. Mesma coisa [que] aquele que você levou." "Sim; então vou levar este também." Aí ele deu, de novo. Foi embora [o amigo].

Aí ele [o amigo], chegou lá, tocava. Aí Ayanama de noite tocava [a que] ele pegou. Aí tocou. Aí amigo dele escutou ele tocar: "Ih!... Será que Ayanama está enganando?" Aí amanhã ele chega de novo. "Aquele que você tocou esta noite, mais bonito daquele que você me deu." "Não é, aquele mesmo está bom!" Aí Ayanama ficou assim, meio bravo com ele. Aí ele deu para ele: "Então você leva tudo!" Deu para ele tudo: "Mas eu não tenho mais comigo, eu já deu agora [a] você tudo" ${ }^{102}$. Aí ele levou. Aí estava tocando lá. Aí à noite Ayanama não tocou. Aí amanhã, amanhã à noite, ele tocou. Aí amigo dele viu ele tocar. Aí amigo dele veio de novo: "Ei, Ayanama, cadê meu jacuí mais bonito?" "Não, aquele que eu toquei hoje à noite, aquele é novo, que eu fiz. Quer ver? Eu vou mostrar. Aqui [está o que] eu toquei."

Aí, tem o avô do amigo dele, que sabia. Aí... bom.

Ele [Ayanama] deu para ele: "Você leva isso. Mais bonito para você." Ele aí foi embora. Estava tocando lá, aí Ayanama não tocou. Passa [um] dia, dois dias, aí ele tocou de novo, jacuí. Aí ele [o amigo] viu tocar também: "Esse Ayanama só ficando mentindo para mim. Está enganando." Aí avô dele dizendo para ele: "Aquele não é madeira, jacuí mesmo. Aquele, Ayanama foi pescar, que ele pegou lá dentro d'água." Aí avô disse para ele; aí ele sabe.

Aí de noite, Ayanama tocou. Aí amanhã ele [o amigo] veio de novo. Aí ele procurava: "Ayanama, cadê aquele que você tocou essa noite?" "Aquele não presta, aquele é novo, que eu fez hoje. Quer ver?" Aí ele

\footnotetext{
$102 \mathrm{O}$ ato de presentear, quando o presente é pedido, é quase compulsório. Vimos a irritação do capitão Kamayurá, Takuma(n), ao ter de ceder às exigências de seus visitantes Kalapálo no Kwarìp de 1965; insistiram em obter uma rede de dormir, e uma rede de "Caraiba", não-indígena. Takuma(n) só os pode atender pedindo a própria rede em que dormia um civilizado presente. No mito, vê-se como a recusa foi interpretada como má vontade, dando lugar à eclosão de hostilidades. De modo inverso, as trocas comerciais ritualizadas, que se apóiam sobre o sistema de especialização intertribal e em prestações e contraprestações de presentes, substituem o contato hostil nas relações entre os grupos da área. Quanto ao rapto das mulheres, foi prática comum enquanto houve ataques a aldeias.
} 
mostrou: "Esse aqui foi [o que] eu toquei essa noite." "Não é esse, esse aqui você não tocou essa noite. Esse aqui, você fez esse [de] madeira só para enganar eu." Aí foi embora.

Aí Ayanama voltava tocando: de noite o avô do amigo dele saiu, de noite. Veio assim andando devagarzinho, aí ele viu. Aí ele voltou, foi embora. Aí ele chegou lá: "Eu já viu, o jacuí de Ayanama. Aquele não é madeira."

Aí amanhã cedo, o amigo dele vem. Aí chegou lá: "Ayanama, aquele jacuí, aquele jacuí que você pegou, eu quero ver." "Eu não tem”, ele falou, "eu não tem não; eu fez aqui jacuí só madeira." Aí eles começou brigar. Ficou bravo, assim para ele. Bom: "Pode deixar para você. Eu não quero não." Foi embora.

Aí o amigo dele tem muito pessoal dele. Aí ele chegou lá, ele falou para o pessoal dele: "Vamos brigar Ayanama?" "Vam'bora", aí todo mundo falar, "vamos brigar." Dois dias fazendo flecha, para matar Ayanama. Quando termina flecha, aí vem. Ayanama está lá tocando. Aí amigo dele vem: "Ô Ayanama, agora você vai me dar esse jacuí para mim." "Eu não dou. Esse jacuí que eu peguei para mim mesmo, não é para ninguém. Esse é meu jacuí." "Não, você tem que me dar." Aí chamou pessoal, para vir matar Ayanama. Aí matou Ayanama. Aí levaram esse jacuí dele, mas não matou mulher dele não, amigo dele carregou. Levou.

É assim.

\section{7 - COMO AYANAMA FEZ YAKUI}

O Ayanama fez [de] madeira, primeiro [de] madeira, o yakui. Para vocês chama palmeira. Palmeira. Mas para nós chama ìmìra. 'İmìra. Ayanama foi tirar imira. Bom, ele fez esse madeira [yakui dessa madeira], Ayanama fez. Aí ele [yakui] não prestou. Então ele botou a [madeira] mais bonita que essa madeira, e [que] para nós se chama yakuitap. Então Ayanama fez só [d]esse madeira. Ayanama fez, [d]esse yakuitap, então ficou bom para ele. Ficou bom.

Ayanama tirou mais madeira. Ele fez yakui, cinco. Aí Ayanama chama outra tribo, e a outra tribo chama ' $I(n)$ mawat; chama ao outro ' $I(n)$ mawat. Esse o nome de outra tribo: ' $I(n)$ mawat. Então ele chamou ' $I(n)$ mawat para ele tocar. Então o 'I $(n)$ mawat chegou lá, na aldeia de Ayanama, aí ' $I(n)$ mawat estava tocando outro yakui. Bom.

Então ' $I(n)$ mawat achou bom esse yakui [o de Ayanama]. Bom. Aí "İ(n)mawat foi falar Ayanama, foi pedir. Foi pedir yakui. Bom, então Ayanama deu para ele. Ele deu yakui três, para ele. Bom. 'I( $n)$ mawat 
passou dia lá, três dias. Depois Ayanama disse para ele: "Quando vocês quiser fazer yakui, vocês tira madeira, não é madeira [como a que vocês usam], assim não é bom não. Vamos tirar madeira bom mesmo; quem serve, madeira, só ìmira. ìmira não é muito bom, não: então você tira yakuitap. É bom o yakuitap; é bom o yakuitap. Bom. Quando você faz yakui, quando tudo pronto, aí tudo pronto, você tem de pescar primeiro $^{103}$. Então você chama a outra tribo, qualquer outra tribo. Chama Waurá, Yawalapití e Kalapálo." "Sim." Então ele deu yakui, Ayanama deu yakui.

Depois, 'İ(n)mawat fez yakui, fez yakui; cinco. Aí Ayanama disse para ele: "Você chama a outra tribo, você chama só homem. Mulher não pode. Só homem mesmo vem fazer yakui." "Sim."

Então 'İ(n) mawat chegou lá na aldeia dele, então 'İ(n)mawat falou para o pessoal dele, aí o pessoal dele foi pescar, passou dois dias lá [pescando], depois volta lá [para a aldeia], passa um dia lá [na aldeia], então ' $I(n)$ mawat manda chamar outra tribo. Chamar outra tribo, que se chama Mariwabera tapya(n)n. Chama essa outra tribo. Então ele ${ }^{104}$ chega lá na outra aldeia, aí Mariwabera tapya $(n) n$ procurava ele: "Vocês está fazendo festa de Kwarìp, ou é outra festa?" "Não, nós estamos fazendo festa de yakui." "Como é esse negócio de yakui? leva mulher? leva muito criança?" "Não. Homem só vai. Não leva mulher não. Só dança lá, só homem mesmo. Mulher não pode ver, nem criança." "Sim". Então ele falou lá: "Você passa aqui um dia; amanhã vocês vai."

Aí passa um dia lá, então esse Mariwabera tapya $(n) n$ vem, fazer festa. Então ele chega lá de tarde. Bom. Mesma hora que ele chegou, estavam dançando esse jacuí. A noite toda. Amanhã também, de dia também dança. Todo o dia. Bom. Quando acabar de dançar o jacuí, então o chefe de ' $I(n)$ mawat preparou esse peixe para ele [para os Mariwabera

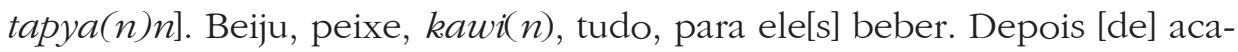
bar de comer, 'T( $n)$ mawat falou para o pessoal, ele dá flecha, esse enfeite de braço, brinco, tudo, arco, tudo. (Presente, não é?) Presente. Porque ele dançou bem lá o jacuí. Se ele não dança bem direito, aí ele não ganha flecha. Nem arco, nem beiju, nem tudo. Passa fome lá. Aí acabou [a festa].

Aí vem embora de lá. Então esse Mariwabera tapya(n)n procurava 'T(n)mawat: "Como é que você faz o jacuî́? Bom, então o 'ì' n)mawat disse

\footnotetext{
103 "Fazer yakui, como "fazer kwarip", significa das coisas: fazer o objeto, e fazer a festa respectiva. É preciso pescar primeiro, pela obrigação de fornecer abundante comida a quem visita.

${ }^{104}$ Refere-se aos pareat enviados para convidar a outra tribo. No fim do parágrafo, o pareat estabelece o número de dias que os convidados devem esperar antes de se porem a caminho para a festa. Quando a demora é grande, uma série de nós, que vão sendo desatados à medida que passam os dias, serve de lembrete.
} 
para ele: "Vocês faz madeira, vocês faz [de] madeira, esse que chama yakuitap. 'Imira não é bom para você. Só yakuitap bom para jacuí." "Sim." Aí então ele ensinou: "Você faz jacuí assim: tira madeira, você racha ele, faz buraco quatro buraco, põe cera na poma, faz buraquinha, aí você toca ${ }^{105}$. Só não pode mulher ver, né?", aí 'T( $n$ ) mawat disse para ele. "Sim." "Quando você terminar esse jacuí, você pode chamar também nós. Aí nós vai para lá." "Sim".

Aí Mariwabera tapya(n)n saiu de lá. Aí mesmo dia ele chegou lá, ele tirou madeira. Aí Mariwabera tapya(n)n fez jacuí lá, aí ele não prestou.

Aí Mariwabera tapya $(n) n$ vem lá falar 'ì $(n)$ mawat como é que ele faz esse jacuí, aí ele ensinou para ele: "Você faz assim, assim, assim." "Sim. ” Aí foi embora. Aí ele chegou lá, fez jacuí, aí ele fez direitinho. Tudo pronto. Então Mariwabera tapya $(n) n$ pesca primeiro, tudo isso.

Aí o chefe de lá, ele manda chamar 'ì $(n)$ mawat. Aí 'ì $n)$ mawat vai lá fazer jacuí. Aí ele chegou lá, mesmo dia dançando, de manhã cedinho. Tem outro que não dança bem, aí esse Mariwabera tapya( $n$ ) $n$ não dança bem. Então esse 'İ $(n)$ mawat dança lá esse jacuí bem. Bom.

Depois, 'I $(n)$ mawat viu esse homem de lá [dos Mariwabera tapya $(n) n$ ], não dançava assim bem, então esse 'T( $n)$ mawat matou ele. Porque ele não dançava bem. Matou o Mariwabera tapya $(n) n$. Aí deixaram o morto lá. Aí İ(n)mawat não ficaram lá não; deixou o morto.

Então esse Mariwabera tapya( $n$ ) n não leva beiju para ele, nem kawi( $n)$, nem tudo. Então esse 'T( $n)$ mawat ficou [com] fome lá, passa fome. Então 'T(n)mawat veio embora de lá, porque ele não comeu nada lá, ele não comeu nada. Então ele deixou morto lá no meio da aldeia. Pronto ${ }^{106}$.

\footnotetext{
${ }^{105}$ Para a técnica de manufatura da flauta, v. Galvão 1953:18. A época do cerimonial é no início da estação seca, quando aumenta a dependência sobre o peixe como fonte de alimentação (Oberg 1953:57).

${ }^{106}$ Embora um pouco confusa a narrativa, vê-se que não só por dançar mal foi um Mariwaberatapya(n)n morto: estes, não dando comida a seus visitantes, faltaram a um dos mais elementares deveres da etiqueta local. No Kwarìp, a comida dada aos convidados entra na teia de prestações e contraprestações que é fundamental na festa, e é mais do que provável que o mesmo se dê na de yakui: o que torna a falta de comida ainda mais grave, por ser a ruptura unilateral das relações de reciprocidade estabelecidas pelo e no cerimonial levado a cabo em comum. Por outro lado, o mito ilustra bem a ambivalência das atitudes no contato intertribal, em que o convívio amistoso esconde uma animosidade latente e um elevado grau de etnocentrismo, agressivo por assim dizer. Ao Kwarìp de 1965, os Kuikúro deixaram de comparecer devido a um conflito que surgira durante a competição de luta de um Kwarìp anterior, realizado em sua aldeia, e que os envolveu e aos Kamayurá. Em 1966, os Waurá abandonaram o Kwarìp dos Kalapálo, porque os pareat não lhes haviam deixado canoas para atravessar um rio, e porque os Kuikúro haviam ridicularizado sua maneira de tocar uruá. Neste último caso, a tensão subiu ao ponto de atingir outros grupos acampados por perto: os Kamayurá concentraram suas mulheres em determinado ponto do acampamento, e prepararam-se para qualquer eventualidade (informação de Roberto Costa Pinho). Apesar disso, desconhecemos exemplos de conflito armado ou mortes resultantes de casos como estes.
} 
Aí veio embora de lá. Bom.

Outro dia 'T( $n$ ) mawat fez, [quis] fazer festa de jacuí, de novo. Então ele vai chamar outra tribo, chama Trumaí. Bom. Aí Trumaí chegou lá. Mesmo dia ele dançou. Então esse Trumaí queria brigar esse 'T( $n)$ mawat, porque ele não levou beiju, peixe, tudo. Então esse chefe de 'T( $n)$ mawat preparou esse kawi $(n)$, peixe, tudo. Levou para ele. Bom. Depois de manhã cedinha, Trumaí dançando, dançando lá, então esse Trumaí queria brigar esse 'ì $(n)$ mawat. Mas o Trumaí [o inf. declara ignorar o nome próprio do indivíduo provocador], ele queria brigar lá dentro da casa. Queria matar chefe de 'ì $n$ ) mawat. Mas o pessoal dele [do chefe 'T( $n$ )mawat não deixou.

Aí Trumaí veio embora de lá. Depois, Trumaí vem brigar. Escondido. O pessoal de 'ì $n$ mawat foi pescar, até encontrar Trumaí. Aí Trumaí matou 'í( $n$ )mawat. Aí começou briga. Aí ele foi assim [que] começou briga. Depois o chefe de 'T( $n)$ mawat mandou procurar esse rapaz, [que estava na] pescaria. Aí ele encontrou [-o] morto. Aí ele viu flecha de Trumaí, aí ele já sabia. Então ele veio falar esse chefe: "Bom, Trumaí matou, o pescaria." "Bom, então vamos brigar." Aí o chefe do pessoal falou para o pessoal: "Pode preparar flecha sua."

Depois, 'I( $n)$ mawat, o chefe de 'T( $n)$ mawat, morreu. Aí İ $n$ )taram um bocado de Trumaí. Aí começou briga, viu? Aí começou briga. Aí todo dia brigar: 'T( $n$ ) mawat vai brigar, Trumaí vem brigar, tudo assim. Até vai assim, brigar. Agora não briga mais, Trumaí. Trumaí acabou só ficou cinco homens, só isso assim. Viu? ${ }^{107}$.

Depois, 'T( $n)$ mawat o chefe de $T(n)$ mawat, morreu. Aí 'T( $n)$ mawat, antigo, não fala assim como Kamayurá. Fala diferente. Agora não fala assim como 'T( $n)$ mawat, agora não fala assim, [os] Kamayurá. Agora, tem um lá, [na aldeia] Kamayurá, fala igual 'ì $(n)$ mawat. Ainda tem lá. Chama Bwabu. Ele não fala direito, assim Kamayurá. Ele só fala 'ì n)mawat. [...] ${ }^{108}$. Bwabu ele fala antigo, ele não fala bem Kamayurá. Assim, não é... Bom.

\footnotetext{
107 Os Trumaí foram a última das tribos hoje culturalmente xinguanas a ingressar na área, e seu ajustamento foi sempre precário, oscilando entre a guerra e a paz com seus vizinhos mais próximos, os Kamayurá, e também com os marginais residentes nas imediações do Suiá-missu. Repare-se que a tradição considera os 'I(n)mawat "Kamayurá antigos”; e os Trumaí ocupavam, na época em que os estudou Quain (Murphy \& Quain, 1955), uma posição nitidamente subalterna quando em interação pacífica com os Kamayurá. Devido a epidemias, guerra, e parece que à marginalização no sistema de trocas comerciais - pelo aparecimento dos machados de ferro substituindo os líticos -, os Trumaí estão reduzidos a 1 aldeia e 21 indivíduos, e localizados próximo ao posto Diauarun do P. N. X. (Galvão e Simões 1964:144).

${ }^{108}$ Bwabu é um dos cantadores do Kwarìp; deve ter entre 40 e 50 anos, e tende a ser o perpetuador dos mitos de que seu pai, Tawapi, era o melhor narrador, segundo o consenso tribal. O informante deste mito, Yanu(n) makakuma(n), tem prática de trabalho com os lingüistas do Summer Institute of Linguistics, e forneceu-nos uma lista de poucas palavras da língua sabida por Bwabu. Este foi reticente e dele nada obtivemos, por enquanto. Eis a lista, na transcrição fonética aqui adotada.
} 


\section{8 - HISTÓRIA DA CASA DE YAKUI}

Antigo, muito tempo, Kamayurá, mulheres, crianças, viu tudo, jacuí. Mulher dança com jacuí, antigo. Então esse Mavutsini(n) chegou lá, no Kamayurá antigo. Aí ele viu a dança de jacuí, mulher também estava dançando com o jacuí, aí Mavutsini( $n$ ) assim, achou ruim. Porque ele dançou com jacuí, mulher, pronto. Bom. Mavutsini( $n$ ) ficou assim triste. Então ele foi falar com o chefe de Kamayurá: "Por que que você deixou dançar, mulher, assim junto de jacuí? Não pode! Esse dança de jacuí, mulher não pode ver não. Esse não é festa de mulher, não é festa de Kwarìp... Esse dança só de homem. Eu danço jacuí, só mulher não pode ver. Então eu faz casa, separado. Eu faz casa separado. Então jacuí dança só lá. Ninguém entra, mulher não entra. Mas nem criança, nem menino."

Bom. Então esse Kamayurá antigo dança jacuí lá dentro de casa mesmo. Tudo mulher fica olhando, assim assim, tudo. Antigo, homem, mulher, fica olhando. Mulher dança também, fica olhando. Mas jacuí dança lá dentro de casa. Tudo mundo viu. Não pode. Aí Mavutsini (n) não achou bom. Então Mavutsini( $n$ ) falou com o chefe de Kamayurá: "Você faz casa separado, você guarda lá jacuí, você guarda lá urivuri ${ }^{109}$. Esse[s], mulher não pode ver."

Então, ele conversou com o chefe de Kamayurá, Mavutsini( $n$ ) conversou; aí Mavutsini(n), disse para ele: "Quando eu dança jacuí, lá onde eu mora, aí [quando] mulher via jacuí, nós, pessoal meu, enterra ele vivo." Aí ele começa a falar assim. "Bom, agora vocês faz assim, como eu. Quando mulher viu esse, vocês pode enterrar ele [a mulher] vivo. Agora mulher não pode ver mais. Agora, [como] esse mulher tudo viu esse jacuí, vocês pode enterrar tudo, não pode ficar mais [nenhuma mulher]. Senão, ele conta para o outro."

Então o chefe de Kamayurá ele enterrava a mulher de Kamayurá tudo. Muito mesmo, enterrava. Então, Mavutsini $(n)$ ensinou para eles: "Vocês faz casa separado. Você guarda tudo lá, jacuí.” Bom. Aí enterravam tudo mulher do Kamayurá. Enterravam tudo, não fica ninguém. Enterrava tudo mesmo. Bom. Aí Mavutsini ( $n$ ) foi embora.

Depois, Kamayurá fizeram casa, aí levaram lá yakui, tudo isso ${ }^{110}$. Aí Kamayurá dança yakui. Aí ninguém viu mais; mulher, com medo. Com

\footnotetext{
${ }^{109}$ Trata-se de um zunidor (roaring-bull), com forma de peixe, que é feito girar graças a um fio atado na ponta de uma vara. Vimos demonstrar o uso de um, em época estranha aos rituais, sem que para isso fosse preciso afastar as mulheres. Provavelmente só são tabuados os feitos sob certas condições rituais, fato ainda a verificar.
}

${ }^{110}$ Sobre o conteúdo desta casa, v. índice: Tapwi(n). 
medo $^{111}$. Aí Mavutsini( $n$ ) chegou lá outra vez. Aí ele viu casa, de jacuí. Aí ele disse: "Agora assim. Agora está bom assim. Não dança mais lá dentro de casa, não pode, agora você pode dançar só à noite, assim fora. Aqui. Agora se você dança de dia, você pode dançar aqui dentro da casa de jacuí. Nome desse casa agora chama Tapwi(n)." Aí ele botou nome, Tapwi(n). Ele chamou casa de jacuí, chama Tapwi $(n)$. Bom: "Você dança aqui mesmo, quando você quiser peixe, $k a w i(n)$, tudo isso, você dança aqui dentro, o chefe traz para você. Não pode dançar lá na casa [residencial]." Aí Mavutsini $(n)$ foi embora.

Aí depois, primeiro ele [os Kamayurá] faz casa pequena. Depois, Mauutsini(n) chegou lá, aí ele manda fazer maior. Tapwi(n) grande, bem grande mesmo. Aí todo mundo dança lá. "Agora assim. Você pode dançar aqui, mulher não pode entrar aqui, nem menino, nem criança. Só homem mesmo entra aqui"112.

Aí Mavutsini( $n$ ) foi embora. Aí os Kamayurá dançaram, dançaram de noite, lá fora.

Aí, tem um mulher, [que] saiu assim fora, aí ele [ela] viu dançar. Então esse Kamayurá pegou ela, aí ele levou ela lá, onde dança, aí mulher ficou lá. No meio de tudo. Amanhã cedinho, o chefe mandou fazer buraco. Quando termina esse buraco, aí Kamayurá leva assim mulher, joga lá dentro do buraco, enterra vivo. Tudos dois. Aí eles enterraram.

Depois, tem outro dança que chama yokoko ${ }^{113}$. Aí ele, mulher, sabe dançar esse yokoko. Essa moça chama Kunya(n)maru. Chama

\footnotetext{
111 Sobre a função destes rituais na manutenção do domínio dos homens na sociedade tribal, v. Shapiro Ms.

${ }^{112}$ A casa das flautas foi acusada, em diversas épocas, em todas as tribos existentes hoje no Xingu, sendo de dois tipos: um, maior, obedecendo ao padrão da casa xinguana; outro, quadrangular, pequeno, como um rancho de duas águas. Em ambos os casos, as entradas são baixas, forçando a pessoa a andar quase de gatas; no primeiro tipo, há duas portas na fachada oriental da casa; no segundo, verificamos só uma. É vedada às mulheres. Mas Oberg (1953:70) descreve duas casas cerimoniais entre os Bakaíri: uma maior, franqueada a todos, e uma menor, onde se guardam as flautas e onde não entram mulheres. Esta orienta-se a leste. As que observamos entre os Kalapálo, Kamayurá e Yawalapití, em 1965, 1966 e 1969, eram do tipo quadrangular, e sua face principal onde fica a porta e onde há um tronco que serve de banco - também era a nascente. Diante dessa face da casa fica o local das sepulturas, e também os kwarìp em sua implantação final para a festa. A proibição ritual parece não se estender às mulheres civilizadas. A antropóloga Adélia Oliveira foi admitida ao seu interior na aldeia Yawalapití, e pôde fotografar os tocadores de yakui - embora fora da época cerimonial.

113 Sego Oberg (1953:55), yokaká é o mama'e(n) do chocalho (maracá) e guardião dos peixes, sendo, também, guardado escondido: acrescenta que à mulher que vir qualquer dos objetos proibidos, cai o cabelo, incha, e fica muito doente. A punição máxima é para quem violar o segredo de yakui, vendo-a: estupro coletivo, e abandono para morrer. Foi-nos confirmada independentemente a questão do estupro, sendo acrescentado que a infratora seria enterrada viva. O mito em apreço omite
} 
Kunya(n)maru. Ele sabe cantar yokoko. (Homem também sabe.) Mas, ela sabe cantar yokoko. Então essa $\operatorname{Kunya(n)maru~saiu,~meia-noite.~Vieram~}$ dançar. Então eles [elas] pintaram lá, tudo enfeitado, aí ficou parecido homem. Aí saíram. Aí estavam dançando lá, tudo. Aí ninguém sabe, disso. Ninguém sabe.

Tem dono de yokoko, aí ele saiu. Aí ele saiu assim fora, aí foi lá onde está ela. Aí ele viu dançando. Aí esse dono de yokoko ${ }^{114}$ ele quis conhecer quem era ele acendeu fogo lá, aí ele ficou olhando assim, mas não conhece. Aí ele não conhece não. Aí ficou lá um pouquinho, fumando, fumando, aí ele não conhece. Aí essa moça estava dançando, ele pensava [que era] homem [quem dançava]. Não é não. Aí esse dona de yokoko foi embora, [para] dentro de casa. Aí mulher dele procurava: "Quem dançando lá fora?" "Não conheço. Eu fiquei lá olhando, eu quis conhecer mas eu não conheça não." Aí mulher dele fez kawi(n) para ele, para a yokoko, peixe, pimenta. Aí ele foi levar para ele: "Aqui tem o kawi(n), tem pimenta, tem o peixe. Você pode comer. Eu não estou conhecendo vocês... Vocês pode vir comer." Aí ele deixava o kawi $(n)$, deixe, pimenta. Aí ele, esse homem, entrou na casa.

Aí não comeram esse peixe, pimenta nem kawi(n). A moça estava dançando. Aí não comeram. Então essa moça cavaram buraco, lá na meia da aldeia mesmo, então ela vai derramar lá, no buraco. Pimenta, peixe; aí não comeu nada. Aí, até lá ficar dançando, a noite inteiro.

Aí, amanhã a dona do yokoko saiu lá fora, tinha muita kawi(n) lá no meio da aldeia, aí ele foi lá. Aí ele procurava: "Quem dançou essa noite?" "Não foi eu não", aí todas Kamayurá [responderam] assim. Ninguém sabe. Tem um irmão de moça, aí ele não sabe também. Então foi procurar, [de] outro Kamayurá: "Quem dançou essa noite?" "Ninguém. Nós estamos aqui à noite, tudo dormindo." Então a chefe dos Kamayurá mandou procurar quem dançou.

Aí foi lá; aí depois essa maça foi lá no lago. Lavou esse sujeira, tudo, só ficou aqui, mas não lavou, não, ficou aqui [sem lavar]. Ele ficou aqui, carvão. Mas não lavou aqui, ficou aqui, ficou por aqui. Aqui lavou tudo. [Com o gesta, indica as partes do corpo que ficaram lavadas e as que a

qualquer alusão à primeira parte do castigo, do qual, aliás, conhecemos apenas uma efetivação concreta. Neste caso, a mulher não foi enterrada, mas, por sua própria vontade ("vergonha"), abandonou a aldeia Kamayurá e foi residir e casar noutra tribo: o que parece evidenciar que nenhum estigma ou impedimento ritual atinge a vítima após o acontecimento.

${ }^{114}$ As cerimônias têm um dono, quer efetivo, quer temporário. Deste último caso são exemplo os donos do Kwarìp, parentes dos mortos, que, naquela festa, arcam com os gastos que acarreta. Vê-se que cabe ao dono do yokoko fornecer comida aos executantes do ritual. 
ficaram mal.] Mas ele [ela] amarra a cabelo assim, ficou igual homem. Ele [ela] usava aquele chapéu...

Aí o chefe de Kamayurá mandou procurar, quem dançou. Aí ele encontrou. Aí ele viu carvão aqui. Aí saiu de lá. Foi falar com o chefe: "Eu encontrei, quem dançou." "Quem foi?" "Aquela moça: dois. Chama Kunya(n) maru." "Então vamos enterrar ela. Mulher não pode dançar esse yokoko." Só homem dança. (Porque mulher [estava] com vontade de dançar, então ela saiu [para dançar].)

Bom. O chefe de Kamayurá mandou cavar buraco. Bem fundo, mesmo.

Tem mãe de moça, tem namorado de moça, também. Aí esse rapaz foi pescar, [o] namorado da moça. Saiu.

Aí o chefe dos Kamayurá, foi lá, fala: "Por que você dançou yokoko esta noite?" Aí ela disse: "Não, não foi [eu] não." Aí ele abriu[-lhe] os cabelos assim, aí ele viu carvão aqui: "Você dançou. Hoje, você vai morrer no buraco." "Pode enterrar, mesmo, não tem nada não. Nós queria morrer mesmo." Então cavaram buraco. Aí, Kamayurá foi buscar ela. Todo os dois [moças].

Tem a mãe dela. O mãe dar para a moça, [isso] que chama 'ita( $n$ ) (esse, [que serve] para raspar mandioca) ${ }^{115}$. Então ele [ela] deu para ela: "Toma; esse você leva, depois, quando os Kamayurá jogam terra em cima, você vai abrindo."

Bom, aí ele pegou, aí enterraram tudo. Aí esse mulher foi cavando. Cavando buraco. Mas ele não morre não. Aí irmã dela morreu, agora esse não morre não, fica cavando, cavando. Aí essa moça vem cavando terra, até chegar assim [à superfície]. Agora, chão aqui. Encontrou, abre buraquinho. Tem uma mãe dela, está chorando lá em cima [da] terra. Aí ele [a mãe] viu abrir buraco. Aí essa moça falava para a mãe: "Você pode trazer água, estou com muito sede. Agora, minha irmã morreu. Só vem eu agora." "Sim." Veio [a mãe] botando água assim, ninguém vê, ela botando água. Ele [a moça] bebendo. Bom: "Agora vou deixar aberto, você pode ficar aqui, esperando." Aí ela tampou esse buraco, bem tampado. Aí a mãe saiu. "Hoje à noite vamos embora, vamos sair daqui."

Aí, meia-noite, foi abrir buraco. Aí ela saiu. Aí não tem mais cabelo. Caiu tudo. Bom. Aí moça saiu. Aí tapou buraco, pronto. Aí foi embora, para a aldeia. [De] outra tribo. Foi lá no meio dos Kuikúro. Foi lá.

Tem o namorado da moça, aí chegou lá, aí ficou bravo com a mãe dela. "Porque é que você enterrou essa moça, você não pode enterrar..." aí ficou bravo, queria brigar Kamayurá, assim. Aí o chefe não deixou.

115 Trata-se da concha de um bivalve fluvial, usada para o descasque da mandioca, e por vezes também para servir de godet com tinta de jenipapo. É instrumento feminino. 
Aí essa moça foi [tinha ido] embora. Ela e a mãe. Aí ficou lá, depois esse rapaz foi lá no Kuikúro. Mas ele não sabe... Foi lá, foi só a visitar Kuikúro. Aí chegou lá. Aí ele viu. Aí ele [não] sabe quem é, também não... Aí essa moça estava trabalhando, lá. Aí essa moça casou, lá. Estava trabalhando lá, mandioca, depois ela saiu assim, lá no lago. Aí esse Kamayurá foi atrás dela, aí ele procurava: "Kamayurá enterrou uma moça lá", ele contar para ela, "Kamayurá enterrou urna moça parecida com você." Aí essa moça falou na língua Kuikúro. Aí ele conversou, lá, isso, enterraram moça... Aí ela disse para ele: "Você sabe, Kamayurá enterrou nós lá. Eu saí do buraco e vim aqui casar." Aí esse homem fazia: "Sabe, né. Ah, você saiu de lá? Eu fiquei lá no pescaria, fiquei bravo [com] Kamayurá." Aí, ele contou. [Ela disse]: "Agora, eu não posso sair daqui, eu já casei aqui. Quando você quiser vem no Kuikúro, você pode vim. Você vai lá com Kamayurá, você não conta para ninguém. Senão, Kamayurá vem me enterrar aqui de novo.”

Aí [o rapaz] saiu de lá. Aí ele chegou lá [na sua aldeia], não diz nada. Aí ele ficou lá.

Depois, outro vai lá. Aí ele viu. Aí volta. Aí depois outro Kamayurá vai lá, aí Kuikúro contou para ele: "Esse moça, veio de lá de Kamayurá. Disse que Kamayurá enterrou ele [ela], saiu do buraco. Essa é ela.” Aí Kamayurá veio contar lá no Kamayurá. Aí Kamayurá foi matar ela. Aí acabou.

\section{9 - OS MAMA'E(N) QUE ROUBARAM URUCU}

Os Kamayurá foram pescar, e levaram yakui, urucu e outras coisas, para se pintarem. Levaram também cabaço, [que se chama] kunya(n)bapi(n)n: é de yakui, mulher não pode ser. Serve para tocar, posto na ponta de um bambu ${ }^{116}$.

Então, esqueceram o urucu e kunya(n)bapi(n)n. Mama'e(n) não tinha urucu. Então os Kamayurá procuravam o urucu e descobriram que tinha esquecido. Procuraram, não acharam mais: mama' e( $n)$ carregou.

Pescaram. Passaram dois dias (pescando); iam passar três, mas não passaram: então voltaram, porque o urucu não dava para pintar todos.

Procuravam urucu e kunya(n)bapi $(n) n$ : "Foi mama'e $(n)$ quem roubou."

Chegaram na aldeia, ficaram tristes, porque não tinham kunya(n)bapi(n)n. Dançaram pouco, yakui, porque estavam tristes.

\footnotetext{
116 É uma buzina de bambu e cabaça. O tubo é de bambu e a cabaça funciona como caixa de ressonância. Encontramos nos Yawalapití uma com o tubo feito de cano plástico. É fêmea: seu

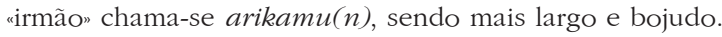


Dez dias depois, dois Kamayurá foram pescar. Acharam um lago, grande. Foram pescar nele. [Quando chegaram] na margem, ouviram mama'e( $n$ ) tocar yakui, ficaram sem saber o que estavam ouvindo. Mama'e $(n)$ tocava igual aos Kamayurá, ficaram pensando que era Kamayurá debaixo d'água, ou mama'e( $n)$. Ouviam também kunya(n)bapi(n)n.

A água começou a subir: "É mama'e(n)!" [disseram]. Esconderam-se.

Dentro d'água, ouviam a dança de yakui. Aí o torvelinho de vento caiu sobre a água e o lago secou: viram yakui, e mama' e $(n)$ dançando. O mama'e $(n)$ que dançava chamava-se $\operatorname{Ipiranyau}(n) n$ [piranha preta], era igual a gente e muito bravo. Os peixes, igual a gente, saíram para uma festa, noutro lugar. Aí Pirabuku, igual gente, dançava yakui. (Era bicuda, mas saiu como gente.) Eram muito altos. Todos os peixes foram para a festa. Pirabuku saiu com o yakui na mão dele.

Um Kamayurá queria falar, mas o outro não deixou: "A piranha come você. Quando o yakui sair, vamos lá na outra festa." Chegaram à festa antes do Pirabuku, ele ficou com vergonha.

Os Kamayurá disseram: "Não tem vergonha não, nós somos bons, viemos pescar, não sabíamos da festa." Pirabuku perguntou: "Aonde vocês vão?" "À festa."

[Pirabuku falou:] "Nós vimos vocês pescando, roubamos o urucu e kunya $(n) \operatorname{bapi}(n) n$, porque achamos bom [gostamos]. Vimos tudo, vocês é que não nos viram. Não levo vocês na festa por causa da piranha. Kunya(n) bapi(n)n e urucu, agora ficam para nós. Roubamos, porque não temos."

O Pirabuku levava muito piqui e peixe para comer na festa, igual a nós: pimenta, tudo. Pirabuku deu pimenta, beiju, peixe assado para os Kamayurá. Eles comeram. Aí Pirabuku disse: "Passamos quatro dias dançando. Daqui a quatro dias espero vocês aqui, para trocar brinco, colar, tudo." Esse mama'e(n) era igual a Kamayurá.

Quando a água tapou [voltou a fechar-se], caindo vento, Pirabuku disse para não pescarem, porque os peixes tinham saído todos: "Vão pescar no outro lago. Os peixes foram para a festa." O vento mama'e $(n)^{117}$ foi atrás deles, para a festa, também.

Os Kamayurá pescaram lá, e começaram a ficar tontos por causa do cheiro que sentiram, dos mama'e( $n)$. Ao meio-dia saíram [de lá], às quatro horas chegaram [a casa]. Deitaram, morreram. Mas não morreram não; só

\footnotetext{
117 Trata-se dos pequenos turbilhões tão comuns no cerrado, ou, vulgarmente, "Saci."
} 
ficaram mortos. Não quiseram comida, disseram que já tinham comido. Mas não tinham, só tinham comido comida de mama'e $(n)$. Aí dormiram. Então, $a(n) n g$ [alma] deles saiu, junto com o mama'e(n) Pirabuku, e foi para a festa.

No outro dia levantaram-se, mais ou menos às nove horas. Perguntaram o que tinha acontecido. Aí contaram tudo, o roubo também. Contaram que tinham ido à festa: "Comida de mama'e $(n)$ é igualzinho à nossa. E daqui a quatro dias vamos lá, esperar." Outros queriam ir, não deixaram: "Não comeram comida de mama' e( $n)$ "118.

Os dois Kamayurá foram, quatro dias depois, para o lugar onde tinham estado. Às dez horas chegou o vento, abriu a água, piranha saiu do lago seco. No fundo do lago, só ficaram uns buraquinhos, que são a casa dos mama'e(n). Nesses buracos, iguais aos que tem no céu, não entra água ${ }^{119}$.

Pirabuku veio atrás do pessoal dele, com comida, e encontrou os Kamayurá, dando-Ihes enfeites, de todas as qualidades, e flechas. Aí contou que tinha ganhado na luta [buka-buka], da outra tribo de mama'e(n), e [contou] tudo da festa.

Os Kamayurá voltaram para casa, mas não ficaram mortos. Mostraram as flechas de mama'e $(n)$, são diferentes das dos Kamayurá. Os enfeites são iguais aos dos mama'e( $n)$. A fruta do buriti é o piqui do mama'e( $n)$.

Aí os mama'e $n$ ) foram para a água, o vento caiu, e a água fechou. Ninguém vê mais.

\footnotetext{
${ }^{118} \mathrm{O}$ encontro dos pescadores com mama'e $(n)$ e suas conseqüências tem todas as características que cercam a doença iniciática dos pajés, desde o primeiro contato até à doença e à morte simbólica. O caso mais próximo ao padrão revelado no mito, e que conhecemos, é este: Takuma(n) estava na roça quando "caiu o vento" e sentiu-se mal, no mato. Veio para casa, onde lhe deram banho, e ele ficou doente como morto. Tentaram uma cura xamânica, mas sem resultado. Então levantou-se, saiu e voltou com taa(n)ngap (boneca), que é mama'e (n) apo ("coisa de mama'e (n)", não se sabendo de que é feita. Pô-la na rede e ela fugiu. (Quando ela foge o pajé adoece.) Ao voltar a si, contou: "Eu não estava doente. Mama'e ( $n$ ) estava me trabalhando para eu ficar pajé». Primeiro, mama'e $(n)$ fez fumo e Takuma(n) fumou "até morrer". "Eu não estava morto?" "Estava", responderam. "Não estava não. Ouvia vocês falarem, eu estava era fumando cigarros de mama'e (n)." Mama'e (n) pôs-lhe coisas nos ouvidos, barriga, boca, mãos, e depois deu-lhe banho e ele ficou bom. Explicava: "Por isso fiquei assim", mostrando as "coisas de mama'e (n)". (A informação foi prestada por seu irmão $\operatorname{Yanu}(n) \operatorname{makakuma}(n)$.

${ }^{119}$ Sobre os buracos que há no fundo do lago celeste e que são morada de mama'e(n), v. fig. 2 e 3. $\mathrm{Na}$ segunda das enseadas formadas pela margem oriental da lagoa Ipavu, também existe um ponto onde se acredita haver três buracos sem fundo, não se podendo aí pescar: é morada do mama'e(n) Tukunare aruwiyap ("Tucunaré grande"). Aliás, próximo dali há uma pequena ilhota, sob a qual fica urna casa de yakui. Tem três portas. Um dia um índio passou e a ilha virou casa de yakui e depois ilha de novo: assim se ficou sabendo. Hoje só os pajés podem ver os mama'e(n).
} 


\section{0 - HISTÓRIA DOS SUIÁ}

Pode ser Kamayurá foram brigar com os Suiá, faz muito tempo. Mataram muitos. Os Suiá mataram um Kamayurá. Os Kamayurá foram, mataram muitos. Os Suiá vieram, mataram dois Kamayurá. Assim sempre, até acabar Suiá, sobraram só dois, porque fugiram para o mato. Havia muitos, mas os Kamayurá acabaram com eles. [Esses dois] dormiram no mato, sem mulheres, sem nada. Os Kamayurá mataram também as mulheres (isto faz muito tempo) $)^{120}$.

Os Suiá choravam, queriam "trabalhar", não tinham mulher. Voltaram à aldeia, fizeram roça e cozinhavam, faziam trabalho de mulher.

Foram pescar, aí encontraram capivara. "Vamos matar." [O outro discordou:] "Vamos pegar, vamos 'trabalhar' ela." Pegaram a capivara, ataram e puseram na canoa." Levaram-na, pegava muito peixe. "Quem vai "trabalhar' primeiro?" "Você, você pegou ela primeiro." Aî "trabalharam" a capivara, todos os dias, até emprenharem a capivara.

A criança nasceu, era mulher. Era uma menina. "Agora temos kunya(n) para nós. A criança morava na capivara, depois andou.

Aí "trabalharam" a capivara de novo, até fazer filho de novo. Era homem, ficaram zangados. Queriam mulher, para os dois terem.

"Trabalharam" de novo. Nasceu mulher. Aí um quis soltar a capivara, o outro não deixou: "Vamos fazer mais mulheres." Aí fizeram mais duas mulheres.

Então soltaram a capivara. As meninas ficaram moças, foram presas, cada um casou com uma. O filho homem casou com a outra filha da capivara (irmã dele) ${ }^{121}$. Aí os Suiá "trabalharam" as mulheres, nasceram muitos Suiá. Esses dois [iniciais] já morreram, só ficaram os filhos deles.

\footnotetext{
${ }^{120}$ Apesar de muito influenciados pela cultura xinguana, e de intercalarem períodos de guerra aberta com outros de convívio pacifico ou pelo menos coexistência, os Suiá sempre se mantiveram mais ou menos marginais. Em termos de prestigio, diz Galvão (1953:38) que estavam abaixo de todas as outras tribos. Não temos meios para saber se a filiação dos Suiá (neste mito) à Capivara provém de uma tradição dessa tribo, ou é apenas menoscabo da parte dos Kamayurá. Há uns 25, 30 anos, os Suiá atacaram os Waurá e raptaram três meninas; estes responderam com uma coligação que os aliou aos Kamayurá e Trumaí. Saquearam o que puderam, mataram umas pessoas e deitaram fogo à aldeia, seg. uma versão que temos do caso. Mas Schultz (1966) descreveu e filmou os treinos de um yawari preparado pelos Waurá, cujos convidados seriam os Suiá: o que parece indicar que, além de abandonar suas incursões, eles tendem a substituir a guerra por relações de paz, e a entrar no sistema de jogos competitivos intertribais que canalizam a agressividade (v. Galvão 1950; Agostinho 1968). Outro mito (32) diz que os Suiá se originaram de uma cobra.

${ }^{121}$ Não temos elementos para avaliar a importância, neste contexto, das relações incestuosas filhofilha da Capivara; e dos Suiá (pais?) com as moças por eles feitas.
} 
Os Suiá de Diauaru(n)n não são Suiá, são só filhos de capivara, porque os Suiá antigos morreram todos. Por isso os Suiá não comem capivara. Não a chamam "capivara", chamam "mãe".

\section{1 - O MENINO-PEIXE}

Uma moça que tem muito tempo (mas eu não sei o nome dela não, tem pai, tem mãe, tem irmão, tudo)... Bom: essa moça foi tomar banho, de manhã, ela foi tomar banho. Aí ela, a moça, chegou lá na beira do lago, aí ela viu peixe pequeno. Peixe pequeno. Bom. Aí a moça disse, a moça disse que vai pegar aquele peixe pequeno. Então, a mulher sentou assim, na beira do lagoa. No lago. Ela sentou. Bom. Aí ela viu o peixe, peixe pequeno. Aí a moça queria pegar, mas não pegou não. Bom. Depois essa moça caiu dentro d'água ${ }^{122}$, ela queria pegar peixe pequeno. Depois essa moça foi mais assim, mais para a frente, então esse peixe estava correndo assim; procurando ele, aí o peixinha entrou no $\operatorname{ta}(n) m a$ [vagina] dela. Pronto. Aí a moça procurava o bichinha, não tem mais. Aí ela não sabe como é que o peixe entrou no $t a(n) m a$ dela; aí a moça procurava peixinha, não achava mais. Aí a moça ficou lá, tomando banho, depois ele [ela] vem, de lá.

Aí chegou lá123, aí a moça contou para o pai: "Eu vi o peixe pequeno lá, eu ia pegar o peixinha, mas sumiu. Não sei aonde o peixinha foi embora; peixinha escondeu assim dentro d'água, não sei aonde foi." Aí depois ela ficou lá, passa [tempo], cinco dias mais, sete dias, aí ela prenhou. Aí o pai dela ficou bravo, o mãe, porque ela estava prenhada. Aí o mãe dela estava zangando com ela, porque ela [a mãe] não acha bom.

Bom. Aí passa, mais ou menos dez dias, pegou o menino nasceu. Aí o mulher, o moça, pensou assim, aí a moça falou: "Será esse, peixinha que entrou meu $t a(n) m a$ ?" Assim, assim... [pensando]. Aí. ela pensou: "Foi mesmo o peixe que entrou meu $t a(n) m a$. no $t a(n) m a$ mesmo, entrou, meu $\operatorname{ta}(n) m a . "$ Aí o menino nasceu, aí nasceu menino. Aí passa dois dias só, aí o menino já andou, o menino já andou. Aí passa mais três dias, aí esse menino ele queria flechar peixe, está querendo flechar. Bom. Então o mãe do menino, ele [ela] manda fazer flechinha pequeno. Aí então essa moça falou para o pai: "Ô pai, você faz arco pequeno para meu menino. Ele tem vontade de

\footnotetext{
122 "Cair n'água" é usado com o significado que tem no português popular do Brasil, isto é, entrar, atirar-se à.

123 "Ela vem, de lá. Ai chegou lá", é uma forma muito comum, usada por este informante para dar idéia de um percurso feito entre dois pontos.
} 
flechar o peixe." Então o pai dela fez arco pequeno para ele, flechinha, de ponta, aí esse menino falou: "Mãe, você me leva lá na beira do lago, eu vou flechar o peixe." "Bom, amanhã cedo vamos, lá."

Aí, amanhã cedo, aí a mãe dele levou. Mãe dele levou. Aí chegou lá, na beira do lago. Aí o menino andando assim, procurava peixe, aí ele viu peixe. Peixe grande. Menino estava assim, bem pequenininho, mas ele sabe flechar, ele sabe flechar mesmo. Aí ele viu peixe. Aí ele flechou peixe, aí ele matou. Aí ele trouxe para o mãe, ele mostrou. "Mãe, eu já flechei o peixe." Aí ele mostrou. Aí o mãe dele acha bom, ele flecha bem. Aí saiu de lá. Aí ficou lá no casa, aí pai de moça viu esse peixe, aí procurava ${ }^{124}$ : "Quem matou esse peixe?" Aí a moça disse: "Esse foi o menino." Aí ele não acreditou não: "Não foi ele não, foi outro [que] flechou para ele."

Depois, [no] outro dia, levou de novo: ela, ele, mãe e pai. Aí esse pai dela falou: "Eu quero ver [se] esse menino vai flechar peixe." Aí chegou lá. Aí menino [que eles tinham levado] estava procurando peixe, aí ele viu peixe. Ai que ele viu, matou peixe, para o pai dela. Aí ele acreditou. Bom. Aí veio de lá.

Chegou lá, a mãe dele estava cozinhando peixe, preparando. Teve um irmão dela, não está gostando dele [do menino]; fica mau para ele.

Aí outro dia tem o tio dele, bom para ele, também, para o menino. Aí esse menino falou para o tio: "Ô tio, vamos pescar amanhã?" "Vamos." "Então vamos sair amanhã cedo." Aí amanhã cedo ele vai. Bom: "Agora você fica na proa ${ }^{125}$. Agora, eu fico aqui na frente. Eu sabe olhar peixe agora você, não sabe pescar. Eu sabe pescar. Eu sou menino, mas eu sabe pescar." (Menino desse tamanhinho assim.) Aí o tio dele levou ele, vai remando um pouquinho, aí ele viu rasto de peixe, esse menino. Ele olhou assim embaixo, aí ele viu rasto de peixe. (Dentro d'água, lá no chão.) Aí ele falou: "Tio, aqui tem rasto de peixe." Aí o tio dele falou: "Tu sabe nada." "Eu sei: tu vai ver hoje, nós vamos encontrar peixe." "Tu sabe nada disso... Como é que eu ainda não vi rasto de peixe?" "Mas você não está vendo", aí ele mesmo disse para ele. Aí ele foi remando, foi remando, aí ele [o menino] encontrou: "Daqui a pouquinho, vamos, vamos encontrar peixe. Peixe está para lá." Aí encontrou peixe. Aí ele falou: "Viu como é

\footnotetext{
${ }^{124}$ Há de ser notado o emprego sistemático, por todos os informantes, do verbo "procurar" com o significado de "perguntar".

125 Por duas vezes aparece "proa" no lugar de "popa", que seria o certo. Enquanto um rema à ré da embarcação, o outro, de pé à proa, mantém-se atento ao peixe para flechá-lo. As flechas podem ter uma ou duas pontas, com farpas de osso, ou, algumas, de arame, prego ou esporão de arraia, presas com fio e cera à vareta (foresbaft), que é dupla quando a arma é de dupla ponta; para pescar, não são emplumadas.
} 
que nós encontrou peixe? Você não acreditava, disse que eu sou mentiroso... Mas eu sei, peixe. Mas eu não sou filho de Kamayurá: eu sou filho de peixe." Aí o menino falou para o tio: "Minha mãe Kamayurá, mas eu não sou Kamayurá. Eu sou filho de peixe. Minha mãe foi tomar banho, aí minha mãe viu eu quando eu estava pequeno, minha mãe pensava era peixe, mas não sou [era] não. Aí eu entrei no $\operatorname{ta}(n) m a$ dela", aí o menino disse para o tio. Bom. Aí encontrou peixe: "Bom, agora você fica aqui, eu vou espantar peixe, para você."

Aí o menino deixou o tio, lá. Aí o menino saiu, assim. Foi espantar peixe, para o tio. Aí peixe veio muito, aí o tio dele estava flechando muito, ele [o menino] também está pegando muito. (Mas ele não está flechando não, o menino: ele caiu dentro d'água e pega peixe na mão.) Aí vem de lá. Aí ele procurava o tio: "Como é, tio, você já matou o peixe muito?" "Matei bocado." "Deixa eu ver." Aí o peixe está lá, só cinco. Aí menino falou: "Só isso que você pegou?" "Só." "Ô, olha como é que eu peguei aqui." Ele [o menino] pegou mais do que ele, ele pegou mais. "Bom, agora vamos embora".

Aí, tem o jiqui. Para nós, chama yikia, para vocês, chama jiqui. Bom: "Agora vamos botar jiqui lá, no igarapé." "Sim." "Bom, deixa eu ver rasto de peixe." Ele olhou assim por baixo: "Bom, o peixe está para lá. O peixe não está voltando, ainda. Está para lá ainda. " Aí cercaram o igarapé, botaram o jiqui lá no meio ${ }^{126}$. "Bom, agora você fica aí, fica olhando, agora vou espantar peixe.” Aí ele fechou [o igarapé]. Aí esse menino foi, espantar peixe, foi bater água, gritou lá dentro d’água; esse menino caiu dentro d’água, foi gritar lá, espantar peixe, assim, gritou, aí o peixe entrou [no jiqui]. Aí o tio dele ficou olhando. Bom. Aí o menino chegou lá. Aí ele procurou: "O peixe já passou por aî?" "Passou." "Já entrou aqui?" "Já". Aí esse menino falou para o tio: "Agora você pode tirar esse jiqui; você pode tirar esse jiqui." "Sim." Aí o tio dele caiu dentro d'água, aí tirou esse jiqui. O tio dele estava com medo desse peixe. Aí esse menino falou: "Não fica medo não, esse peixe não te morde não."

Aí esse menino foi e caiu dentro d'água. Aí tirou esse jiqui, aí o tio dele falou: "Como é que eu vou tirar esse peixe de dentro do jiqui?" "Tira com a mão." "Mas eu não sei tirar." Aí o tio dele estava com medo. "Tira assim." Aí ele ensinou. Aí ele tirou muito peixe, por dentro [de dentro d] o jiqui, aí botando dentro da canoa.

\footnotetext{
${ }^{126}$ O jiqui é armadilha para peixe. Fazem uma tapagem com plantas aquáticas, isolando o igarapé ou enseada da corrente principal, e, em certas aberturas deixadas, põem o jiqui. Tentando escapar, o peixe entre nele.
} 
Mas, esse menino conversa com o peixe; ele pega peixe vivo, ele conversa com ele. Mas o tio dele não sabe conversar. Aí acabou: "Agora vamos embora."

Aí vem de lá. Pegaram muito peixe, aí ficou lá na casa. Aí a mãe dele procurava: "Seu tio pegou quanto peixe?" "Ele pegou pouquinho. Agora eu, peguei muito peixe. Meu tio não sabe tirar peixe, assim, do jiqui, estava com medo.” Aí mãe dele estava. cozinhando o peixe, a irmã dessa mulher também, estava assando, peixe.

Aí outro dia, outro tio dele levou-[o a] pescar. Mas não acreditou: aí o outro tio estava contando como é que ele pegou peixe muito. "Bom: amanhã eu vou levar ele, eu quero ver esse menino," Aí amanhã foi. Saiu ao meio-dia. Pronto. "Você vai ver como é que eu vou pegar peixe. Seu irmão falou para você, você não acreditava..." Aí foi. Ele disse primeiro assim: "Eu sento aqui na proa, você fica aqui na frente. Eu quero ver você flechar peixe." Aí esse menino foi remando, foi remando, foi remando, aí o tio dele viu peixe, aí o tio dele não flechou o peixe. Aí o menino falou: "Eu não pesca assim não. Quando eu vi o peixe, eu não errava assim, peixe." "Então vem aqui, eu quero ver você." Aí o menino foi. Aí o tio foi remando nele, remando, remando; quando ele viu o peixe, ele matou. Aí, ele falou: "Ó aqui: eu matei peixe."

Aí, esse chegou lá, no igarapé, ele procurava rasto de peixe, aí ele viu rasto. Aí ele viu rasto: "Aqui tem o rasto de trairão, aqui tem o rasto de cachorra, aqui tem rasto de pintado... Vem ver!" - ele chamou. Aí ele procurava, assim, não viu não: "Mas eu não vi rasto de peixe!..." "Mas você não viu! Quem viu sou eu! Eu sou peixe." Aí ele falou: "Você fica aqui, vou espantar trairão para você ver."

Aí ele deixou o tio: "Você fica olhando aqui, quando você viu o peixe, você mata." Aí o menino saiu. Foi lá no meio do lago, ele caiu. Foi espantar peixe lá, dentro d'água, gritou assim, ficou gritando lá dentro d'água. Aí ele pegou pintado cinco. Na mão. Aí o tio dele não mata nada. Só ficava olhando. Aí o menino chegou lá. Aí falou: "Já matou peixe?" "Não. Eu fiquei aqui só olhando."

Aí esse menino ficou com raiva com o tio, ficou zangado. Aí ele deixou tio lá. Aí menino foi embora. Deixou o tio. Aí chegou lá na casa. Aí o mãe dele procurava: "Cadê seu tio?" "Eu deixei lá." Aí falou: "Por que?" "Porque ele não mata peixe, fica só olhando, por isso é que eu deixei lá." Aí, manhã cedo, ele foi buscar o tio. Ele dormiu lá [o tio dele], porque ele ficou zangado. Bom. Aí o menino falou para ele: "Você não morreu não, tio?" Aí o tio diz que não: "Eu não morri não. Eu fiz aqui capim, para mim dormir..." "Então vamos embora." Aí trouxe o tio. Aí chegou lá. 
Depois, outro dia, o irmão da mãe, outro, levou [o menino]. Aí ele levou de novo, pescar. Aí ele não levava flecha, só levava aquele jiqui. "Você não pode levar flecha, nem eu não estou levando flecha também." Aí ele levava só esse jiqui. Aí foi. "Agora vamos pegar peixe só curimatá." Aí chegou lá, cercaram igarapé, agora vão botar aqui jiqui, ele levou três jiqui. "Agora, você pode ficar aqui olhando. Quando o peixe vem, você não grita.” Aí menino saiu. Foi lá no meio do lago, ele caiu: foi espantar peixe. Caiu lá, espantava peixe lá, ficou gritando assim, quebrava lá a vara, para espantar o peixe, assim. (Bate na água, lá dentro d'água. Bate o chão lá.) Aí o peixe vem, entra muito, lá no jiqui. Aí o menino vem, vai procurar: "Já entrou peixe muito?" "Já". "Então tira." Aí ele mandou. Aí esse tio dele caiu dentro d'água; mas ele não sabe tirar. Aí ele tem medo; piranha também entrou no lá, jiqui, aí tio dele falou: "Como é que tira?" "Tira com a mão." "Não, eu tenho medo, essa piranha." "Não, essa piranha não tem nada não." Aí esse menino foi tirar. Tiraram muito peixe, tiraram esse curimatá. Aí ele falou: "Agora vou conversar peixe.".

Aí ele conversou. Aí esse menino falou, ele falou assim: "Outro dia, eu venho pegar você também", aí o menino falou com o peixe. "Sim", [disse o peixe], "outro dia, chegando outro dia, você vai morrer aqui." "Não, eu não morro não." Aí o peixe falou com esse menino: "Eu traz, no outro dia eu traz cobra, cobra come você." "Sim... Eu quero ver! Pode deixar." Aí vem de lá.

Aí passa quatro dias, aí ele veio de novo. Chegou lá, cercaram o igarapé de novo, aí botaram o jiqui. Mas cobra já foi. Aí ele viu rasto de peixe muito, aí ele viu rasto de cobra. Aí ele viu assim; bom. "Eu vi rasto de cobra aí; cobra está para lá. Eu quero ver hoje cobra..." Aí, mas o tio dele não foi com ele, só ele foi. Aí foi espantar peixe. Caiu lá dentro d’água, espantava muito peixe, assim, batendo no chão, lá, aí ele viu cobra. Aí esse menino foi lá perto de cobra. Ele pega rabo assim, puxando assim. (Lá cobra nós chama moi $(n)$, nós chama cobra moi $n$ ), cobra dessa grossura, como gente.) Aí esse menino puxava o rabo da cobra, aí cobra comeu, esse menino. Aí menino não voltaram [voltou] mais. Depois a mãe dele estava chorando, por causa desse menino, mas a mãe dele já sabia que cobra comeu ${ }^{127}$. Aí acabou.

\footnotetext{
${ }^{127}$ As sucessivas provas a que é submetido - o menino embora sempre iguais - dão ao mito uma estrutura que se pode considerar iniciática; isto e o fim um tanto abrupto da narração indicam que se trata de uma versão fragmentária e incompleta. Quase esperaríamos ver ressurgir o menino, transformado. De fato, Oberg (1953:108-109) recolheu, entre os Umutina, um texto muito semelhante. Nele, uma moça leva um peixinho lambari para casa, e ele vem a metamorfosear-se num rapaz, que acaba por morrer: de seus testículos se originou a batata doce, dos olhos a pimenta, das orelhas o feijão.
} 


\section{2 - A MOÇA PRENHE DE COBRA}

Antigo, tinha moça solteira, mas não tem homem, um rapaz para ela. Só tem irmão, cinco irmão. Mas não tem rapaz para ela. Essa mulher tem vontade de namorar com rapaz, mas não tem um rapaz para ela. Bom. Então essa moça foi para a roça arrancar mandioca. A moça está arrancando mandioca, então ela arranjou ovo lá dentro buraco. Ela pensa [que é] ovo de passarinho, de bacurau, mas não é não. Bom. Acabar de arrancar mandioca, ela ajunta mandioca. Ela ajunta mandioca, vai botando mandioca dentro do cesto. Então ela pega ovo, [e põe] em cima de cesta. Bom. Aí vem de lá. Aí ficou lá na casa, aí ela contava: "Eu arranjei ovo, ovo de passarinho, eu trouxe ovo para mim criar."

Aí outro procurava ela: "Deixa eu ver ovo." "Tá aqui, eu vou te mostrar para você." Aí a moça tirando mandioca, aí o ovo estava quebrado, não tem mais ovo. "Ih!... Ovo está quebrado, não presta mais." Bom: a mulher estava suando, muito, porque ela carregou muita mandioca. Então o ovo quebrou, água de ovo misturou [com o suor], assim, nela, entrou na coisa [vagina] dela. Bom. Depois, ela foi banhar. Tomando banho lá, lavando sujeira, acabando vem. Chegou lá na casa.

Depois, passa, cinco dias, mais dez dias, aí essa moça prenhou. Essa moça prenhou. Aí o irmão dela achava ruim, porque ela prenhou, sem marido. Aí o irmão dela estava xingando para ela, ficou [com] a raiva: "Ih, porque você prenhou assim, sem marido, você solteira não pode prenhar" ${ }^{\prime 28}$. Tem outro irmão dela bom para ela. Depois, irmãor[s] dela foi para a roça. Saiu tudo. Só ficou ela na casa, sozinha. Ficando lá, depois vai crescendo, essa, essa coisa [barriga] dela, até crescer, até ficar grande. Irmão dela ficou bravo para ela, também: "lh, por que você assim? Prenhava, assim não tem

\footnotetext{
${ }^{128} \mathrm{~A}$ atitude não vem de um preconceito contra relações pré ou extra-conjugais, mas do fato de haver gravidez. Não se admite o nascimento de um indivíduo a que falte o apoio social, biológico e econômico da família nuclear. Laraia (1967:28-30) vai mais longe, ao valorizar o papel procriativo do pai e minimizar o da mulher, no quadro cultural desta sociedade tupi. Nisto afasta-se das interpretações que há para o sistema de parentesco xinguano (Galvão 1953; Dole 1964), que o consideram bilateral. Diz aquele autor: “... deveres recíprocos... existem principalmente em função do pai. Por esta razão, a mulher tupi pode denominar o filho por um termo descritivo que significa ufilho de meu esposon. Assim, a existência de filhos sem pai é considerada bastante estranha, levando freqüentemente à prática do infanticídio. Um mito Kamayurá exprime bem o espanto da coletividade diante de uma mulher solteira e grávida: «Por que ela prenhou sem marido? Ela não tem marido. Ela prenhou. Ficou assim, não sei porquê. Ela não tem marido, nós tudo tá certo, nós prenhar está certo, nós tudo tem marido. Agora ela não. Ela sem marido prenhou" (p. 28). Adiante, informa: "Apesar da tendência de alguns autores em considerarem as sociedade xinguanos com bilaterais, estamos procedendo segundo a hipótese da existência de ênfase sobre a descendência patrilinear, conforme uma nossa análise anterior” (p. 29, n. 19).
} 
marido..." Ficou bravo. Aí depois essa mulher estava chorando, ficou assim triste, porque ela prenhou.

Outro dia, irmão[s] dela foi para a roça, foi trabalhar. Depois a mulher saiu na estrada, aí ela viu o fruta, chama macaúba, para nós chama mokayìp. Mokayìp. Aí ele [ela] viu fruta, aí ela começou a falar: "Ih, aqui tem fruta bom, para comer, eu tem vontade de comer aquela fruta", está dizendo. Daqui a pouco, essa cobra saiu, nela, então essa moça viu essa cabeça de cobra. Aí essa moça ficou olhando assim, aí a moça falou: "Ih, eu estou assim, como é que eu [estou] assim? Eu pensava essa [que isso era] menino." Aí essa moça ficou pensando: "Será que aquele ovo que eu peguei, ovo de cobra? Ovo de passarinho?" Ficou assim falando, ficou triste lá, depois voltou, lá na casa. Depois irmão dele [dela] chegou. Aí falou para ele: "Eu não está bom, porque eu pensava aquela, ovo de passarinho, mas não é não. Aquele que eu peguei, ovo, ovo de cobra." Aí o irmão dele ficou assim pensando. Ficou triste. Aí o irmão dele [dela] pensou: "Bom, então amanhã cedo eu vou procurar árvore, tem fruta. Manhã cedo, eu vou levar você lá, vamos ver que esse cobra vai sair tudo.”

Manhã cedo, ele leva. Aí ele encontrou esse árvore. Aí a moça começou a falar: "Eu tenho vontade de comer aquele fruta." Aí cobra saiu, cabeça. Cobra vai subindo, na árvore, vai subindo, vai subindo, até tirar fruta. Tiraram fruta para ela. Acabar de tirar, aí cobra desce. Cobra desceu, entrou dentro, nela. Aí o irmão dela falou: "Como é que nós vamos fazer [com] essa cobra?" Aí o irmão dela falou: "Não sei como vai fazer." Bom. Chegaram lá na casa. "Manhã cedo, eu vou procurar árvore, mais grande."

Aí o irmão dela saiu, bem cedo. Aí ele encontrou árvore, para nós chama iwira, árvore grande. Ele encontrou, tem fruta, ele voltou. Ele chegou meio-dia: "Aí, encontrei, árvore. Manhã cedo vamos lá, de novo."

Aí manhã cedo ele leva para lá. Chegou lá na árvore: "Agora você vai sentar aqui; mais longe." Aí mulher sentou. Aí a moça começou falar de novo: "Como é que vou tirar aquela fruta?..." Aí cobra saiu de novo, saiu cabeça, cabeça dele saiu. Aí cobra subiu, no árvore. Árvore mais [muito] grande, mas cobra não acaba. Até tirar fruta, mas cobra não acabou. (Não saiu não, ainda ficou.) Aí cobra tirou fruta, tirou para ela, aí cobra desce de novo, entrou dentro nela. Pronto.

"Bem, manhã cedo, eu vou sair, vou procurar buriti; buriti. Você pode ficar lá amanhã na casa, amanhã vou procurar buriti." Aí ficou lá na casa.

Amanhã cedo, bem cedo mesmo, irmão dela saiu. Foi procurar buriti, dentro do mato. Aí ele encontrou buriti. Aí ele voltou. Irmão dela veio fazendo estrada para ela, até sair [do mato]. Aí chegou lá: "Eu encontrei buriti. Vamos ver amanhã cobra vai acabar." 
De manhã cedo, primeiro mulher tomou banho. "Vou tomar banho primeiro." "Sim, você pode tomar banho." Aí ela toma banho lá, aí vem. "Vam'bora. Eu encontrei buriti." Até chegar no buriti. Aí mulher, a moça, senta como está aqui assim [de pernas abertas] lá, lá no carro ${ }^{129}$, buriti está assim, como daqui lá no carro. "Vôcê pode sentar aqui, mais longe." Aí a moça sentou, aí o irmão dela ficou lá com ela. Aí a moça começou a falar de novo: "Eu tenho vontade de comer fruta, fruta de buriti; quem vai tirar para mim?" Aí cobra saiu. Cobra vai andando, no chão, vai andando, vai andando, vai andando, vai procurar buriti. Até [que] ele [ela] viu buriti. Então cobra subia no buriti. A cobra vai subindo. Mas o buriti muito, muito alto. Muito alto, esse buriti. Aí o irmão dela falou: "Ainda não saiu tudo?" "Não, ainda não." "Sim; essa cobra não chegou lá, na fruta." Aí cobra vai subindo. Aí irmão dela procurar: "Ainda não saiu, no rabo?" "Ainda não." "Então você chega mais para lá." Aí mulher assim, vai andando, aí o rabo saiu. "Saiu o rabo?" "Saiu." "Então você pode levantar." Aí mulher levantou. "Bom. Agora eu vou cortar", irmão dela falou.

Pega em facão (não é facão não, pedaço de tábua, que faz assim [gume]), aí o irmão dela vai cortando essa cobra, pedaço, cortando, cortando, cortando, até que chega à cabeça. Quando cabeça vem assim, corta cabeça, pronto. Aí saiu tudo. Assim é a história, viư ${ }^{130}$.

\section{3 - HISTÓRIA DE ANTIGO}

Bom, vou contar história de antigo.

Antigo, os Kamayurá antigo, uma moça tem vontade de namorar com rapaz. Mas o rapaz, esse rapaz, não tem vontade [de] namorar. Esse antigo. Bom.

Mulher com vontade de namorar com rapaz, mas rapaz não tem vontade namorar com ela.

Então essa mulher foi na estrada, ele [ela] escolheu um toco, pau, ele [ela] escolheu lá, que acha bonito; então mulher ele [escolheu] para namorar esse toco. Depois mulher voltou lá na casa dela, mulher voltou lá lá na casa dele [dela]. Aí mulher ficou assim, meio assim, fica alegre, assim; depois mulher pintou. Mulher estava pintada, assim, de urucu, jenipapo. Bom.

\footnotetext{
${ }^{129}$ Indicava um automóvel estacionado a alguma distância. O mito foi recolhido em Brasília.

${ }^{130} \mathrm{O}$ mito Umutina de origem do milho é quase idêntico, envolvendo também a fecundação da moça graças aos ovos de uma anaconda. V. Oberg 1953:108. Esta versão Kamayurá está incompleta, pois não diz que dos pedaços da cobra se originaram os Suyá.
} 
Mulher saiu, foi namorar com o toco. Mas os outros não sabiam que ele namorava com toco. Depois, tem muito rapaz que não tem vontade de namorar essa moça. Tem muita moça, tem muito rapaz. Bom. Depois mulher foi, namorar esse toco. Namorava todo dia, leva beiju para esse pau, leva kawi(n), peixe...(Mas pau não come beiju! Pau não come peixe!... [o in.. ri-se do absurdo]).

Aí, ele [ela] chega lá, mulher abraça esse toco, para ela ele conversa, esse toco. Assim, diz que essa moça está namorando com os outros rapaz, esse pau está dizendo para ela. Para ela, conversa. Namorava lá, namorava, abraçava, fica alegre, assim, depois voltou, na casa. Ela fica todo o dia assim. Todo dia, todo dia.

Bom, então esse rapaz queria namorar com ela. Ele tem companheiro, esse rapaz. Aí ele falou para o companheiro: "Eu vou namorar aquela mulher, aquela moça, estou gostando ela." Bom, depois esse rapaz foi esperar na estrada. Foi lá atrás do toco, esperar ela.

Primeiro mulher faz beiju, peixe, aí daí a pouco mulher saiu, foi lá na estrada, foi lá assim, meio alegre assim, foi rindo, para o toco, assim. Vai andando, vai andando, assim... Chegou lá. O rapaz pensa que ela vem conversar ele. O rapaz pensa. Depois esse rapaz olhou assim toco, esse rapaz escondeu, sentou assim escondido. Aì mulher abraçava toco, assim, aí mulher falou para esse toco: "Come peixe, come beiju, você bebe, depois nós conversa." Ninguém escuta essa conversa de toco. Mas só ele conversa. Mulher também conversa toco, mas ninguém escuta, conversa dele. Ficou assim alegre, assim, estava abraçando. . .

Aí, daqui a pouco, acabar de conversar, mulher "trabalhou" toco. "Trabalhou" toco. Aí rapaz ficou olhando assim para ela, assim, ficou assim, falando: "Moça já está assim, conversando assim toco, 'trabalhando' toco!... Agora eu vi, essa moça."

Depois, esse rapaz saiu de lá, foi embora, foi contar para o companheiro dele. Aí o rapaz contou, lá: "Eu já viu moça, estava 'trabalhando' o toco. Mas aquela moça tem vontade de namorar, ela arranjou toco para namorar." Aí o colega dele não acreditou. Amanhã cedo, ele vai de novo, esperar: "Vamos lá esperar ele [ela]. Você vê."

Aí foram esperar. Aí mulher saiu de casa. Tudo pintada, assim, com jenipapo, leva beiju para toco, peixe, kawi(n), tudo. Aí chegou lá. Aí essa toco estava ciumando essa moça; toco estava ciumando essa moça, ele disse que namorando com os outros, assim. Aí assim. Aí ela, assim, não sei o quê: "Eu não estava namorando, [estou] namorando só você" - abraçava assim, daqui a pouco "trabalhou" de novo. "Trabalhava" lá. Aí esse rapaz ficava olhando, para ela: "Ih, assim!..." 


\section{Mulher foi embora.}

Amanhã cedo, homem vem, com rapaz. Pega machado lá, para cortar toco. (Machado de pedra.) Aí chegou lá, cortaram toco. Aí jogou no mato. Aí fica lá, esperando. Aí mulher vem, essa moça. Moça chegou lá, não tem mais toco. Moça chorava lá, porque o rapaz cortou o toco. [O inf. ri, divertido.] Aí a mulher chorava lá, assim, ficou triste.

Depois, chegou lá na casa, ele [ela] foi tomar banho, lavou tudo esse corpo de urucu, jenipapo, lavou tudo ${ }^{131}$. Bom. Depois, esse rapaz contou para a turma: "Nós vimos moça, namorando toco, a moça estava namorando o toco lá, nós vimos, nós cortemos o toco, nós vimos moça chorava lá, por causa do toco." Bom. Esse é assim.

\section{4 - HISTÓRIA DA MOÇA QUE QUERIA NAMORAR}

Uma moça, antigo, uma moça estava muito doente, porque ele tem vontade de namorar, também. Ela tem muita vontade, mas ninguém quis, namorar. O rapaz, tem muito, antigo, mas não tem vontade de namorar. Bom.

Dois dias, mulher ficou doente, ela [com] vontade, mas ela [com] vontade mesmo: ficou doente. Bom. Depois os outros, mulheres, homens, foi para a roça. Depois volta. Ainda não sabia, esse pessoal, dela. Outro dia, [o pessoal] foi arrancar mandioca; aí depois um rapaz, [diz] assim que entrou lá na casa dela. Aí, entrou lá, não tem ninguém: só ela ficou. Aí um rapaz entrou lá: "Ih, aqui não tem ninguém... Só ficou doente..."

Aí, foi lá perto dela. Aí ele procurou: "O que é que você tem, hem, moça?" Aí não respondeu. Aí ele foi mais assim perto dela, ele procurava de novo: "O que é que você tem, moça?" "Eu estou doente, estou doente muito." "Por quê?" "Porque, assim... Estou doente mesmo." Aí, daqui a pouco, começou a falar, essa moça, ela falou para o rapaz: "Você quer me levar, lá fora, para fazer cocô?" "Não, eu não leva você não, eu te mato, você!" "Não, você não mata eu não. Você me carrega." "Sim. Então eu carrego você." Ele carregou. Levou lá na fora: "Aqui?" "Não, aqui não, mais para lá.” Aí ele levou mais para lá, um pouco. Aí: "Pode fazer."

Aí ele [ela] começar falar; começou a falar assim: "Eu quero isso." Aí esse rapaz procurava: "O quê? O que é que você quer?" "Eu quero essa.” Aí o rapaz procurava assim: "O que é que você quer de mim?" "Eu quero essa!" “Ah, essa não, essa aqui, você faz comigo, eu te mato!” "Não, você

\footnotetext{
${ }^{131}$ Não se pintar é demonstração externa de tristeza; os enlutados. p. ex., atravessam um período em que lhes é vedado pintar o corpo e cortar o cabelo.
} 
não mata eu não. Se você 'trabalhar' eu, fica bom." "É mesmo?" "É sim." "Então vamos 'trabalhar"”. "Olha lá, hem! Eu te mato... Eu te mato você, hem!" "Não, não mato não. Vai ficar bom" [disse a moça]. Aí homem "trabalhou." "Trabalhar" nela, aí acabou de "trabalhar", aí essa moça correu, não ficou mais doente não. Ficou bom. Aí moça correu.

Aí chegou lá na casa, chegou pintado ela. (Essa moça estava magro, mesmo, muito magro.) Chegar lá, estava pintado, pintado com jenipapo, urucu, fez o beiju lá muito.

Aí os outros chegou lá da roça, aí os outros olhava nela: "Ih, você já ficou bom? Que foi isso?" "Eu ficou bom mesmo. Porque eu não estar doente mais..." Assim; mas ela não falou como é que foi.

\section{5 - HISTÓRIA DA REDE}

Antigo, os Kamayurá usavam uma rede, uma rede com embira. Embira, mesmo. Bom. Kamayurá fica fazendo rede, com embira, só embira; outro faz [com] o capim, outro faz sapé, outro faz outro embira, cipó, [com] qualquer [coisa] ele faz. Bom. Então, as outras tribos, Kamayurá, Kamayurá mesmo, os Kamayurá fala diferente. Então outra tribo fala mesmo assim de fala Kamayurá. Outro Kamayurá não fala como Kamayurá não. Kamayurá fala..., assim, bem diferente. Kamayurá mesmo mas não fala igual. Então os Kamayurá chegou lá na aldeia do Kamayurá, chegou lá, fica olhando a rede dele ${ }^{132}$.

Aí procurava: "Como é que você faz rede, para dormir?" Bom, então outro explicou para ele: "Nós faz rede, para nós, com embira só. Outro faz cipó, outro faz sapé, outro faz de capim. Nós fica assim." Aí outro falou: "Não é assim não; nós não fica assim. A rede de nós é do fio do buriti." Aí esse Kamayurá não sabe como é esse buriti não. Não sabe. Bom: "Você dorme bem com embira?" "Não, nós não dorme bem com ela não, aí deixa o corpo doendo, esse, braço doendo, bem, não fica bom para nós." "Bom; então vou trazer essa rede de nós para mostrar para vocês.” Aí foi embora.

Aí ele chegou lá, está contando: "Eu já viu rede lá, com embira só. Outro faz com raiz de cipó, outro faz capim, outro faz sapé. Aí fiquei assim olhando, com a rede deles. Bom, então expliquei para eles: não é fazer assim rede, vocês não sabem como é que faz rede, eu expliquei para eles.” Aí fica contando lá, no meio da turma. "Bom, quando eu voltar para lá, eu

\footnotetext{
${ }^{132}$ Os Kamayurá de fala diferente voltam à cena, e num contexto que parece indicar a existência, no passado, de grupos com dialetos diferentes; indicio que é reforçado por outros informes que obtivemos. Esta narrativa, aliás, não tem cunho mitológico, acentuando-se nela o caráter histórico-lendário e as idéias sobre a difusão de certos elementos culturais.
} 
vou levar rede para mostrar para eles." Aí passa o dia lá, mais ou menos três dias, aí ele voltou [à outra aldeia], aí ele trouxe o rede.

Aí ele chegou lá. Aí ele mostrou: "Ô, rede aqui. Essa rede mesmo, não é rede embira, não é rede cipó, não é rede de capim.” Aí esse Kamayurá fica olhando, esse rede, acha bom. Bom: "Agora, vou ensinar vocês como é que se faz rede.” Aí ele ficou lá, ficou morando lá. Ficou morando lá. Bom: "Agora vou mandar buscar dois mulher, para trabalhar rede para vocês, para vocês aprender"133.

Aí chamou mulher. Dois mulher. Aí amanhã ele vai tirar buriti. Tira muito mesmo, muito, muito mesmo. Aí ele tira fio, lá. Primeiro tira fio, fio de buriti. Aí esse fio de buriti, leva aí fora para secar. Manhã cedo, ele faz fio, até ficar um rolo assim. Em rolo. Então ele vai tirar a madeira. Dois pau: então ele coloca assim, assim. Então a mulher pega aquele fio de buriti, vai rodando esse pau, vai rodando, até ficar assim [o inf. demonstra]. Mulher pega barbante, para o [rede], como assim, até ficar pronto. Então esse homem pega fio de buriti também, fazer corda, fazer corda, ele fica fazendo. Aí ele está pronto. Depois, corta essa corda, assim, coloca a corda assim, puxa assim, aí vai tirando rede. Aí a rede apareceu, lá: "Assim nós faz rede, lá. Assim feito de embira, não presta. Com cipó, sapé, não presta para vocês", fica falando para ele[s]. Bom: "Agora vocês faz assim rede. Assim nós faz rede lá", [está] falando para ele. "Assim ficar melhor para vocês." Depois fazer rede muito lá, aí vai aumentando, esse rede, vai continuar, aí nasce rede lá. Aí Kamayurá faz rede, lá. Primeiro Kamayurá mesmo, usava rede com embira, cipó, sapé. Agora, os outros Kamayurá, já sabe como é rede. Outro Kamayurá não sabe.

Aí tudo mundo usava rede, lá. Aí saiu rede lá, para ele. Aí não faz mais rede com embira, não fazem mais com o rede de cipó. Aí acabou. Assim começou rede, viu.

\footnotetext{
${ }^{133}$ A confecção de redes é trabalho feminino. Segue-se a explicação da técnica. Obtido o fio de buriti para a urdidura e de algodão para a trama, passa-se à “tecelagem” (na verdade um trançado) da rede. Entre dois troncos de mediana grossura, espetados verticalmente no solo, dão-se muitas voltas da urdidura, horizontalmente e de forma que a trama fique em posição vertical. Depois «tece-se» com uma técnica de trançado de fio duplo (twinned), com os fios duplos dispostos dois a dois e com um espaço entre cada par de fios duplos. A "malha" das redes de homem é mais fechada que a das de mulher. As pontas dos fios de algodão são atadas e cortadas de modo a fazer uma franja muito espaçada ao longo da borda. Por vezes, os três primeiros pares da trama em cada extremo da rede são tingidos com urucu. As alças de suspensão formam-nas os fios da urdidura; as cordas de amarrar são também de buriti e dobradas a meio, tendo quatro ou mais pernadas para cada alça. O seio dessas cordas passa por dentro do seio das alças da urdidura, de modo a daí resultar um nó-direito cujos firmes são de idêntica extensão, servindo para atar a rede a seus suportes, geralmente com uma espécie de volta-da-ribeira.
} 


\section{6 - HISTÓRIA DE PANELA}

Primeiro, Kamayurá fez panela. Saiu bem muito bem. Depois. Waurá não sabia ainda, fazer panela ${ }^{134}$. Depois, Kamayurá fazendo muito panela, mesmo. Aí outra tribo, Kuikuro, Kalapalo, trocava panela, só de colar. Colar de unha também, de onça. Antigo ${ }^{135}$.

Depois Waurá viu como é que faz panela, aí Waurá foi tirar barro, lá dentro d'água; mas aqui não tem barro bom, lá só tem lá. Aí o Kamayurá levou o Waurá [e mostrou] como é que tira barro. Aí ele viu. O barro fica parece cera. Parece cera. Bem preto, mesmo. Aí ele trouxe o barro. Aí Kamayurá fez, panela, bem grande. Aí Waurá viu, como é que faz panela. Aí muito, muito panela mesmo, lá no Kamayurá. Muito.

Aí depois Waurá saiu de lá. Porque Kamayurá ensinou ele, a trabalhar panela. Antigo já trabalbou muito panela. Agora não trabalha mais.

Bom. Agora Waurá saiu. Aí ele foi tirar o barro. Aí ele fez panela, aí não saiu bem.

Depois, Waurá veio de novo, aí Kamayurá ensinou ele de novo: "Você faz assim, você faz primeiro, você queima, aí saiu bem. Depois, você pinta com jenipapo, aí fica bom.” Aí Waurá foi embora.

Então Waurá ficava fazendo panela, muito, mesmo. Depois de pinta, assim, aí saiu bem. Depois Waurá falou: "Esse panela, agora vou fazer muito. Só troca colar. Não vai trocar nem arco, nem flecha. Só troca colar." Aí depois Waurá fez muito panela.

\footnotetext{
${ }^{134}$ Quando v. d. Steinen penetrou no Xingu em 1884 e 1887, as tribos ceramistas eram as do grupo Aruak. Lima (1950), que estudou a cerâmica Waurá em pormenor, informa que a única mulher Kustenau sobrevivente (que morava na aldeia Waurá) era excelente nesse trabalho; e que os Mehinaku, conhecendo a técnica, não atendiam sequer às próprias necessidades. Os Yawalapití já não fazem panelas, o que se pode atribuir à falta de matéria-prima. Esta é obtida no leito do Batovi, em ponto afastado da sua aldeia, pelos Waurá. (Parece que perto do Posto Jacaré, da FAB, existe um depósito de argila apropriada, mas não utilizado.) O fato de se dizer que é preta, como cera, vem com certeza da quantidade de matéria orgânica que incorpora (v. Lima 1950). Como têmpera, usa-se a matéria silicosa resultante da queima de esponjas fluviais (Tubella sp. ). São fabricados os objetos maiores pela técnica do enrolamento, e pela da modelagem os menores; uma combinação de ambas aparece nos tamanhos intermédios. Quanto aos Kamayurá, não há nenhuma notícia histórica a respeito de uma manufatura habitual; mas Galvão (inf. pessoal) verificou que a técnica não é desconhecida entre suas mulheres. À parte o interesse que haja na versão do mito enquanto evidência de uma perdida tradição ceramista - o que é discutível -, cabe ressaltar seu valor como manifestação do profundo etnocentrismo de cada unta das tribos xinguanas.

135 Junqueira (1966) identificou o que considera "níves de valor" no sistema de trocas intertribais, figurando as panelas, os colares e os arcos pretos no mais elevado deles. São também estes os produtos da especialização manufatureira, e aqueles que aparecem no mito das origens como traços distintivos tribais, ou atributos identificadores. Toda troca se processaria no mesmo nível de valor, idealmente. O texto mostra adiante a recusa de objetos julgados impróprios para o comércio.
} 
Então Kuikuro foi lá no Waurá. Esse Kuikuro queria trocar panela com flecha, com arco. Mas Waurá não quis trocar. Então disse para o Kuikuro: "Você pode trocar esse panela, só de colar. Colar de unha, e colar de pescoço." Aí o Kuikuro voltou, Kuikuro levou colar, colar de pescoço, colar de unha. Aí Kuikuro trocou lá: "Agora está bom. Agora troca panela só [com] colar."

Aí depois o Kalapalo veio no Kamayurá, ele quer trocar panela com arco branco. Aí Kamayurá não gostou [do arco branco]. Aí Kamayurá disse: "Este arco não presta. Não presta nada." Então: "Arco bom para nós, esse se chama iwirapapita(n)ng”. Aí o Kalapalo não sabe fazer iwirapapita(n)ng. Bom. Então Kalapalo chegou lá, trocava panela só colar, com Kamayurá. Então o Kalapalo vem trocar, arco [branco] com o [arco] preto; ele quer trocar com o arco branco. Aí Kamayurá não gostou: "Esse arco não presta. Não atura não. Esse [preto] arco bom.”

Kamayurá ensinou ele a trabalhar arco preto. Tudo dia Kalapalo chega lá, pedia, arco preto, aí Kamayurá achou ruim, então ensinou eles a fazer arco preto.

Depois, Kamayurá não faz panela. Agora só faz panela só Waurá. Quem começou fazer panela, Kamayurá. Waurá não. Waurá que aprendeu. Aí os Kalapalo fizeram arco preto, aí não fizeram mais esse arco branco. Arco não presta. Depois, Waurá fez panela muito, aí os Kamayurá trocaram com ele[s] também, panela. Depois Kamayurá não faz panela mais. O Kamayurá já fez, muito, agora não faz mais. Agora faz só Waurá. Agora, Waurá já sabe bem fazer panela, agora.

\section{7 - HISTÓRIA DE TRUMAÍ}

Os Trumaí antigos não tinham flecha. Só usavam cipó para amarrar viado, tartaruga...

Quiseram pescar: um tirou muito cipó, foi à aldeia e deu [distribuiu] o cipó. Ai pegaram a canoa e foram para o rio, onde havia tracajá. Pararam Ia. Fizeram fogão, bem grande.

Um Trumaí caiu n'água, procurando tartaruga, sem respirar, debaixo d'água. Não encontrou tartaruga, só kari, um peixe cascudo e com espinho. Aí, o Trumaí subiu, e pegaram muito kari. Um pegava kari no fundo, os outros esperavam. Aí encontrou um bem grande, o kari prendeu a mão dele e o Trumaí ficou lá, preso. Outro foi olhar, unha uma pedra grande, e [o primeiro] estava debaixo da pedra. Deixaram-no lá, não teve jeito de tirar. 
O Trumaí não morreu: estava esperando o kari abrir os braços. Demorou muito; bem tarde, seis horas da tarde, o kari soltou-o e o Trumaí subiu, logo.

No outro dia, foram pegar tracajá, levando muito cipó. Procuraram e acharam tracajá. Primeiro fizeram fogo, depois caíram n’água.

Depois, os Kamayurá foram pescar e pensaram que eram lontras, capivara, ariranha, e viram o fogo. Mas não viram os Trumaí. Viram também o cipó. Esperaram os Trumaí saírem: caíram n'água bem cedo, às seis horas, e saíram eram dez horas, lá do fundo. Os Kamayurá esperaram.

Tinha [lá] muito beiju de Trumaí, de milho. Aí os Trumaí saíram, com muito tracajá. Aí os Kamayurá perguntaram como é que pescavam. "Pegamos. Não temos flecha, não sabemos flechar. Nossa flecha é este cipó."

Os Kamayurá mostraram flecha aos Trumaí, disseram que era com aquilo que pescavam. Os Trumaí disseram que não sabiam fazer flecha nem arco. Os Trumaí foram ver pescar com flecha. Antes comeram milho ${ }^{136}$.

Trocaram beijus. Os Trumaí deram muito tracajá, para os Kamayurá levarem. Os Trumaí foram olhar, ver flechar peixe. E depois deixaram os Trumaí no porto. Os Trumaí disseram: "Nós queremos aprender a fazer flecha."

Os Trumaí ensinaram os Kamayurá a pegar tracajá, mergulhando, mas Kamayurá não tiveram coragem de ir até ao fundo.

Os Kamayurá foram dizer ao [seu] chefe que os Trumaí queriam aprender a fazer arco. Aí o chefe falou: "Bom, primeiro vamos brigar com os Trumaí." Ficaram escondidos [emboscados] no pesqueiro de tracajá. Os Trumaí vieram, de canoa, sem flechas. Fizeram fogões, caíram n’água, e os Kamayurá foram esperá-los, perto do fogo. Aí os Trumaí saíram; os Kamayurá disseram: "Queremos tracajá." "Está bem, vamos primeiro assar." Deram muitos tracajás. Primeiro os Kamayurá comeram, depois, depois os Trumaí. Aí os Kamayurá mataram todos.

\footnotetext{
${ }^{136}$ Ver o contraste entre os índios de cultura xinguana e os recém-chegados: não tinham flechas, comiam carne de tracajá com beiju de milho. Os do Xingu tinham flechas, alimentavam-se de peixe e, verifica-se no fim do relato, de mandioca. Uma observação de v.d. Steinen é significativa: "Os Trumaí tomaram emprestados, em parte dos Nu-Aruak e em parte dos Tupi, os nomes das plantas úteis mais importantes... Revelam-nos a língua e a tradição que só mais tarde os Trumaí foram instruídos na agricultura por seus vizinhos, e encontramos entre eles plantações extensas e otimamente cuidadas" (Steinen 1940:247). Max Schmidt refere-se aos tão temidos Trumaís, "que sabem dormir debaixo d'água e do fundo dela atiram flechas sobre seus inimigos" (1942:73). De passagem, diz v. d. Steinen: "Se os Trumaí, como deles se afirma, fossem animais aquáticos do fundo do rio..." (1940:240) Viria esta crença de uma versão Trumaí do mito das origens: Awalanaxe Kute parecia peixe e vivia n’água. Wamutsini - equivalente Trumaí de Mavutsini(n) - pescou-o e deu-lhe a definitiva e bela forma humana (Murphy \& Quain 1955:74).
} 
Depois, os Trumaí foram lutar com os Kamayurá, sem flecha. Quando chegaram, na aldeia dos Kamayurá, levavam só varas para brigar ${ }^{137}$. Os Kamayurá ganharam, mataram todos. Pegaram um [prisioneiro]. Ensinaram-no a fazer flecha, arco, borduna, tudo. Aí os Kamayurá disseram ao chefe dos Trumaí: "Agora vocês sabem fazer arco, não podem mais brigar com Kamayurá.” Os Trumaí fizeram muitas flechas, arcos. Os Trumaí, aí, aprenderam a fazer roça de mandioca ${ }^{138}$.

\section{8 - OS TRUMAÍ APRENDEM YAWARI COM AYANAMA}

Ayanama brigava com Trumaí, mas queria casar com Trumaí. Ele era Trumaí. Aí Ayanama foi embora, porque os Trumaí não gostavam dele. Depois os Trumaí brigaram. Ayanama foi para a aldeia dele. Os Trumaí ficaram tristes, tinham apanhado. Fugiram para o mato, com medo de ir para a aldeia.

Um Trumaí saiu, ficou no mato sem comer, bem magro. Todos os dias, dormia no mato, e procurava Ayanama. Um dia achou mato queimado, lá dentro do mato, achou roça. Era de Ayanama, estava seca, por causa dos porcos do mato ${ }^{139}$. Tinha mandioca, cana, cará... O Trumaí pegou cana e chupou; pegou batata, cará, e comeu; dormiu no meio da roça.

\footnotetext{
${ }^{137}$ O contato primeiramente pacífico não excluiu a traição posterior; e o revide Trumaí usando "varas só para brigar" seria alusão ao passado uso guerreiro do propulsor, a cujo respeito há noticias em v. d. Steinen (1940:140-141) e Max Schmidt (1942:365). Descrevendo seu inopinado encontro com os Trumaí perseguidos pelos Suiá, em 1887, refere o primeiro autor (1940:154): "Os homens pegaram em armas e juntaram-se, num aglomerado delirante e frenético, sacudindo os arcos, as flechas e os dardos". O grifo é nosso. O uso estender-se-ia aos Trumaí e Awetì (Steinen 1940:140-141). Hoje, a arma serve só para o jogo do yawari (v. Galvão 1950; e mito 28), já existente naquela época.

${ }^{138} \mathrm{O}$ prisioneiro de guerra é mostrado como veículo de difusão cultural e como agente aculturativo. A adoção pelos Trumaí dos padrões de cultura xinguanos (ou quando menos de muitos de seus elementos culturais) e sua resultante integração no sistema de relações pacíficas são sintetizadas na declaração dos Kamayurá ao chefe Trumaí. Há evidências concretas do prisioneiro que aprende e ensina técnicas: as canoas de tipo juruna foram introduzidas entre os Trumaí por um de seus membros, algum tempo preso pelos Juruna (Murphy \& Quain, 1955); estas canoas, aliás, foram também trazidas para os Kamayurá por Marika, que viveu com aquele outro grupo Tupi, onde aprendeu a técnica de sua fabricação.

139 Os porcos do mato obrigam que se façam cercas de pau nas roças, nem sempre eficientes. Sua ação, aliada à das formigas, chega a destruir 50\% da produção potencial de uma roça, atacando os porcos as plantações e a saúva os estoques nas aldeias. Isto obriga a plantar uma "margem obrigatória" além da necessária para o consumo, margem essa que não se confunde com o excedente estocado para os primeiros meses das chuvas. Estes resultados correspondem a observações realizadas entre os Kuikuro (Carneiro 1956, 1961), mas a uniformidade do sistema adaptativo na área permite, provisoriamente, generalizá-los.
} 
Uma mulher da família de Ayanama veio buscar lenha, viu rasto, procurou até achar o Trumaí sentado. A língua de Ayanama era Trumaí. Conversou com ele, ele contou por que tinha fugido para a aldeia de Ayanama. Aí foram para a casa de Ayanama; chegaram lá, o pessoal de Ayanama jogava muito yawari.

Ayanama aceitou [que ficasse na aldeia], deu-lhe rede. Disse-lhe que ia aprender a dançar yawari, deu-lhe o yawari [propulsor e dardo] e enfeites. Trumaí aprendeu a jogar e treinar. Todo o dia ensinavam. Depois, [Ayanama] fez festa de yawari, mandou os pareat chamar os índios de outra tribo ${ }^{140}$.

Os outros mandaram avisar que demoravam cinco dias. [Enquanto] esperavam, não comiam peixe, não "trabalhavam" kunya(n), só podiam comer caça, batata, cará, beiju ${ }^{141}$. Cinco dias depois os outros chegaram, e o Trumaí dançava, com todo o pessoal de Ayanama.

A outra tribo chegou. À noite, foi treinar no taa $(n)$ ngap [boneco] ${ }^{142}$. O pessoal de Ayanama foi treinar também.

Os da outra tribo dormiram no mato. Ayanama mandou fazer kawi $(n)$, depois os pareat foram levar comida e bebida à outra tribo. (A comida é do chefe, mas pareat é quem leva. Só se chama uma tribo) ${ }^{143}$.

\footnotetext{
${ }^{140}$ Galvão (1950) descreveu e interpretou o yawari, enquanto mecanismo de canalização ritualizada de impulsos hostis. No texto, um antigo inimigo deixa de o ser e aprende yawari. No mito seguinte, 39, vê-se que há consciência do antagonismo e dos sentimentos que motivam os participantes de um jogo competitivo. No caso do yawari, do "arremesso de paus", da luta corporal e do jogo de bola, opunham-se ou opõem-se duas tribos; isto é, a competição desenvolve-se entre dois grupos sociais definidos, autoconscientes e opostos: autoconsciência essa reforçada pela própria oposição.

${ }^{141}$ Além destas restrições, também não se pode dormir na noite anterior ao jogo: sonhar com ferimento ou derrota acarretaria o ferimento ou a derrota. Pode-se comer carne, o que não é hábito comum. No dia seguinte ao do envio dos pareat, bem cedo, e depois de tomar banho, usam um emético de folhas de yawa'ì e raizes de 'apo maceradas n'água, e também da raiz mo'itséem (raiz doce). A seguir vomitam dentro da lagoa, ajudando-se nisso com os dedos enfiados na garganta. Após o vomitório é que não podem mais comer peixe e ter relações sexuais. É possivel que isso se ligue à sensibilidade olfativa dos mama'e $(n)$, mas de momento nada podemos adiantar. Não tendo de lutar, o "dono da festa" está isento de restrições.

${ }^{142}$ O taa(n)ngap é feito de palha de buriti, e serve de alvo para os treinos que precedem o duelo com propulsores, entre membros das duas tribos participantes. (De população, e fatores externos desejo de tornar mais espetacular a festa -, estão levando a que participem do yawari mais de duas tribos. A antropóloga Carmen Junqueira comunicou-nos ter observado a cooperação de Yawalapití num yawari promovido pelos Kamayurá, sendo covidados os Kalapálo e Kuikuro; recentemente, vimos os mesmos dois grupos cooperando na aldeia Kamayurá, e tendo como visitantes Waurá e Mehinaku - o que parece indicar uma tendência para a institucionalização da nova forma da festa, pelo menos entre os Kamayurá.) Os dardos têm ponta romba revestida de cera, e só podem atingir as pernas.

${ }^{143} \mathrm{O}$ "chefe", isto é, o "dono da festa". A este cabe fornecer a comida necessária. O yawari é uma festa de propriedade fixa e hereditária, e pertence, nos Kamayurá, a Kurimata, mulher de Takuma(n):
} 
De manhã pintaram-se todos. O sol nasceu, foram treinar, duas vezes. Depois o pareat chamou a outra tribo.

Dançaram rodando, primeiro os da aldeia, depois os outros. Depois separaram-se: os da aldeia de um lado, os outros do outro, com os chefes sentados no apikap [banquinho] na frente deles. (O chefe da aldeia fica de pé.) O pessoal de Ayanama acertou. Dançou alegre, à volta do terreiro. Os outros ficaram tristes.

Aí Trumaí aprendeu a jogar yawari e voltou, para ensinar aos outros. Aí os Kamayurá aprenderam com os Trumaí144.

\section{9-COMO COMEÇOU O JOGO DE BOLA}

Quem começou o jogo de bola $[\text { ma(n)ngap amomoap }]^{145}$ foi a onça. Warakuni $(n)$ estava namorando sua irmã e "trabalhando" ela, comendo. Aí o pai [deles] bateu-lhe. Aí Warakuni( $n)$ disse à irmã dele; "Ago-

como mulher, não pode exercer as funções "executivas" do cerimonial, que delega a seu marido; este, por extensão, passa então a ser considerado também "dono". Também no Kwarìp os visitantes não podem dormir dentro da aldeia, e acampam no mato: neste caso, os motivos são de ordem mágica e simbólica. O pareat é sempre o intermediário entre os dois grupos em confronto.

${ }^{144}$ O mito da origem da festa registado por Galvão (1950:355) é diferente. Quem sabia yawari eram os Kawabib; Kwat jogou yawari com o filho do herói Kawabib, Panheta e, acertando-lhe na cabeça, matou-o, e os Kawabib acabaram. Kwat depois trouxe o jogo, ensinou-o aos Kamayurá, mandandoos atirar na coxa para não matar. Mas o mesmo autor refere a tradição histórica da introdução pelos Trumaí. A favor desta tradição estaria uma noticia de v. d. Steinen: "Os Trumaí empregavam um método singular (de proteção peniana)... Atavam o prepúcio diante da glande com fio de algodão geralmente tinto de urucu. A extremidade anterior do pênis assemelhava-se a uma ponta de chouriço" (1940 :235). Em 1965, observamos, no Posto Leonardo Villas Boas do P. N. X., um índio Kalapálo com o mesmo tipo de proteção, que, como se sabe, não é própria dos xinguanos. Mas este caso único assume outras proporções, devido ao fato de se acharem os Kalapálo a caminho de um yawari na aldeia Kamayurá. Se bem que indício mínimo, poderia tratar-se de persistência de um traço, em contexto ligado aos introdutores do jogo. Ainda sobre este, v. Schaden 1965: 76 n.

${ }_{145} \mathrm{Ma}(n)$ ngap amomoap, lit. "jogo da mangaba". O nome deriva-se de ser a bola utilizada feita com o látex da mangabeira; chama-se ma(n)ngap aruwiyap, "mangaba grande". O campo de jogo, ma(n)ngawarape ("caminho da mangaba"), tem desenho semelhante ao das sepulturas dos indivíduos da classe morerekwat, ou antes, da cerca que as envolve, sendo, no entanto, de maior extensão. O mesmo desenho ocorre, construido com sapé e varas, pelo lado de dentro do teto da casa do capitão Kamayurá. Deve recordar-se que quando as mulheres mandadas por Mavutsini(n) se aproximaram da aldeia das onças, estas estavam jogando bola (v. mito 1). Uma das descrições que obtivemos da bola - houve várias, e discrepantes, prestadas por informantes Kamayurá -, aproxima-se desta: “Os Awetì possuíam bolas de borracha, mas de consistência maciça. A seiva duma figueira ou da mangabeira é enrolada sobre o peito para dar-se-lhe a forma duma pequena esfera que em seguida é macerada com água de cinza; fazem-se furinhos em toda a superfície da bola, de modo que parece revestida dum trançado. Tingem-se as bolas com vermelho de urucu" (Steinen 1940:424). É a primeira referência histórica a respeito. 
ra vou embora, não vou ficar mais aqui não." Não quis mais ficar com o pai dele ${ }^{146}$.

Aí pegou kamayiwirawi(n) [taquari] e fez moi $(n)$ buku [cobra grande] e ela começou a andar, e ele foi montado nela. E foi-se embora, montado, viajando na cobra grande, passando pelas aldeias e dizendo que ia à casa do tio. E o pessoal das aldeias ensinava-lhe a estrada da aldeia [do tio] ${ }^{147}$.

Aí chegou na aldeia de Terutsi $(n)$ [rolinha "fogo-apagou" e disse que ia na casa do tio. O passarinho disse que era perigoso, se fosse lá, o tio, a onça, podia matá-lo. Aí ele ficou naquela aldeia, e Terutsi( $n$ ) mostrou [como havia fartura], dizendo que comia só beiju, outra coisa não. Kawi(n) também, peixe, tudo.

Aí Nyapakani( $n$ ) [gavião] começou a cantar, e o rapaz ficou ouvindo, dizendo que era o passarinho do tio que estava cantando. A onça criava o Nyapakani(n). E o rapaz disse: "O caminho é por aqui." Então Terutsi $n$ ) foi buscar polvilho da onça e trouxe, e fez beiju [para o rapaz].

Aí o rapaz chegou lá fora, assim, perto da casa da onça; a moça estava varrendo a casa e foi deitar o cisco no mato. Ele chamou a moça, ela mandou esperar. E voltou, entrou lá, voltou de novo e chamou o rapaz.

Warakuni $(n)$ entrou: a moça disse que os pais não estavam, estavam pescando. Aí entrou dentro de casa, ela puxou o banco e sentou, e puxou a cerca dos meninos presos, miritsi, e Warakuni $(n)$ ficou preso lá dentro, com a moça.

\footnotetext{
${ }^{146}$ O texto não explica se é irmã biológica ou classificatória, mas o contexto indica antes o primeiro caso. Em termos do mito e das regras de casamento, Warakuni(n), é, de qualquer forma, culpado de relações incestuosas. Ao bater-lhe, e ao acarretar com isso o afastamento do filho, o pai faz prevalecer a regra de exogamia na família nuclear - estabelecendo porventura aqui o paradigma mítico para esse comportamento. Não é preciso dizer que a regra existe e aplica-se tanto aos casamentos intratribais como aos intertribais; e é deste último caso que trata o presente mito, das atitudes e sentimentos que suscita e das formas de os enfrentar e resolver. Abandonando sua casa. Warakuni(n) vai buscar mulher fora, e na desta - que é noutra aldeia, das onças - sofre a hostilidade de seu grupo familiar imediato (os sogros) e dos demais membros do grupo da esposa. O que corresponde às relações de evitação com sogros e cunhados, e a atitude pouco receptiva dos homens da tribo para com aquele que, vindo doutra, nela se casou, coisa por nós observada na prática. Segundo nosso intérprete, o personagem principal acaba por se ir da morada dos sogros. Isto conforma-se ao que se verifica: residência matrilocal temporária, seguida de residência patrilocal ou mesmo neolocal. Neste caso, comum dos outros grupos co-residenciais e não em construção isolada, aproveitando a flexibilidade das regras residenciais para procurar um melhor ajustamento. Cabe ainda dizer que a matrilocalidade temporária não se aplica aos "capitães"; e que há casos em que um homem, casando fora de sua tribo, passa a viver na que adotou, definitivamente, acabando por ser aceito. Sobre as normas que presidem os matrimônios, v. Galvão 1953.

${ }^{147}$ Warakuni(n), abandonando as relações incestuosas com sua irmã, parte para a casa do tio, onde achará mulher: o "tio" é, obrigatoriamente, um “irmão" da mãe, dado o sistema de parentesco Kamayurá; mais adiante é isto confirmado textualmente. O casamento com as primas cruzadas, já foi dito, é considerado preferencial.
} 
Então a moça disse: "Daqui a pouco meus pais vão chegar, agora você vai comer isto." Era milho torrado. Aí a moça estava ensinando Warakuni(n) a lutar como o pai dela lutava, buka-buka. Sempre o pai dela ia pescar, e a moça ensinava o rapaz a lutar.

Aí a onça encontrou a cotia, e queria matá-la. A cotia disse: "Não me pode matar não. Por que não mata aquele rapaz que está namorando com tua filha?"

Então a onça chegou em casa, disse à filha dele: "Cadê, minha filha, o rapaz que está namorando com você?" Aí abriu o miritsi, tirou o rapaz, pegou o apikap, e puseram o rapaz no meio da casa: a onça examinou-o, procurando arranhão (mesmo o menor). Se tivesse, ela comia [o rapaz]. Então o rapaz não tinha nada. Aí a onça examinou, examinou tudo, tudo mesmo. A mulher dele também, e não achou nada.

As quatro horas, foram lutar com o rapaz. O rapaz ganhou da onça, e da mulher e da mãe da onça. Se perdesse na luta, a onça comia-o. (Eles estavam já casados [o rapaz e a moça].)

Depois a onça matou a anta e deixou-a lá, até apodrecer. Aí falou para a filha dele: "Minha filha, agora manda o rapaz apanhar a anta." Aí [essa] mulher falou para o rapaz, ensinou assim, como se apanha bicho podre. Enfiou-lhe algodão no nariz, para não sentir o cheiro de bicho podre.

Quando o rapaz foi, a onça foi também, escondida, devagar. Ai chegou lá, o rapaz pegou a anta podre e veio, correndo. A onça já tinha feito o lugar da anta ficar, que chama tupe (aquele cesto raso que parece peneira). Aí o rapaz chegou, sentou, e a onça limpou o rapaz todo, com a língua, e quando acabou o rapaz entrou dentro do quarto onde morava.

Aí a onça preta encontrou a cotia, que disse que Warakuni( $n$ ) namorava sua filha. (Esta onça era parente da onça e por isso era pai também, porque era irmão da onça.)

Aí a onça preta chegou, examinou tudo, no pescoço, mas não tinha machucado nenhum. Aí parou.

De tarde o rapaz foi lutar com a onça preta, e ganhou tambem, não perdeu.

Aí veio também a onça vermelha, examinou o rapaz. Nada. À tarde foi lutar com ele, também. Nada: perdeu. De tarde a onça vermelha foi lutar com o rapaz, de novo.

Aí vieram uma porção de onças, também, e Tarawi( $n$ ) estava também com elas, essa onça pequena (gato do mato). Ele [o rapaz] lutou e ganhou dessas onças todas. Mas ele não lutou com o Tarawi(n). Se ele lutasse, o rapaz perdia de Tarawi $(n)$. 
Chegaram, antes do meio-dia, todas as onças: "Agora, vamos jogar bola, ver se esse rapaz é bom para jogar a bola, mesmo.” Aí primeiro trouxeram pedrinhas do tamanho de bolas, para treinar. Aí, sempre eles jogavam. A onça pensava que o rapaz não sabia jogar bola. Jogaram pedrinha para o rapaz: se ele não soubesse, tinham-no comido. Jogaram muito, até Warakuni( $n$ ) cansar, e aí a mulher [dele] foi jogar [substituiu-o] ${ }^{148}$.

Aí dormiram, levantaram e saíram com a pedrinha, e a onça disse: "Quem vai jogar primeiro?" Sua mulher respondeu: "Quem vai jogar primeiro sou eu." Aí jogaram, jogaram, com pedrinhas assim [o inf. mostra o círculo formado pelo indicador e polegar, juntos]. O rapaz quase matou o sogro com a pedrinha, porque o rapaz era bom mesmo.

Depois foi de novo a mulher da onça, e o jogo foi igual, como quando jogou com o sogro. O rapaz sabia jogar porque sua mulher tinha ensinado, escondido, tinha ensinado a lutar. A moça chamava-se Kura(n)m.

E o jogo foi de novo. A onça jogava para o rapaz, ele pegava logo, e o rapaz jogava para a onça que pegava também. A onça queria matar o rapaz com aquela pedrinha. Aí entrou a mulher do rapaz, no lugar do rapaz, jogando a pedrinha também. Aí a onça disse: "Ah, $\operatorname{Kura}(n) m$, $\operatorname{Kura}(n) m$ é danada, não sei como arranjou esse rapaz." Todos queriam casar com ela, e todos que iam lá, as onças comiam, passavam o dente ${ }^{149}$. Só Warakuni( $n$ ) escapou, sem nada, porque era bom mesmo. Aí acabou de jogar com todas as onças, com a pedrinha.

Então começaram a jogar com a bola. O sogro podia jogar com ele mas não quis, e passou-o para jogar com a turma dele [onça]. Aí foram jogar bola com ele [Warakuni(n)], eleeamulher estavam jogando bola, juntos ${ }^{150}$.

\footnotetext{
${ }^{148}$ Não temos evidência alguma da participação de mulheres no jogo, quer através de nossos informantes indígenas, quer da comunicação epistolar amavelmente feita pela antropóloga Ellen Becker, que o observou entre os Kalapálo, ao iniciar-se a época do piqui em 1966. Aliás, o significado do mito e do jogo não se deve esgotar no que dissemos em notas anteriores, ou nas que se seguem: mas, por enquanto, ainda não penetramos nos possíveis simbolismos de ambos, que poderiam estar relacionados com a maturação dessa fruta, ou com o status de chefia: é de recordar que o desenho que marca a casa do "capitão" e as sepulturas dos morerekwat tem a forma do ma(n)ngawarape. Sendo que é essa a designação que recebe o existente na casa do chefe.

${ }^{149}$ É patente o sentimento de hostilidade vigorante nas relações do rapaz com seus parentes por afinidade; a semelhança dele com o existente entre a sogra e a nora no mito de origem de Kwat e Yaì, torna-se por demais evidente. Por outro lado, vê-se como o jogo e, atrás, a obrigação de ir buscar um animal podre assumem as características de uma série de provas, incluídas num estágio probatório, correspondente ao período (probatório?) em que o recém-casado reside na casa dos pais da mulher.

${ }^{150}$ Repare-se como, face à atitude hostil do grupo formado pelos afins, a esposa passa a formar com o marido um outro grupo que se lhes opõe. É interessante ter Oberg observado (1953:45-46) que o genro e sua mulher deviam pendurar as redes no extremo oposto ao ocupado na casa pelos seus sogros. Pessoalmente, não temos confirmação para o fato, antes pelo contrário; por exemplo, Tawapì,
} 
Pelas quatro horas, a onça foi lutar. Aí falaram para Kura(n)m: "Agora é bom de lutar com agente, buka-buka." Primeiro lutou com o sogro, o rapaz ganhou. Depois foi a mulher da onça [a sogra do rapaz], e o rapaz ganhou. Aí $\operatorname{Kura}(n) m$ disse: "Não derrube mamãe com força, para não machucar a velha." Aí a moça disse: "Ah, $\operatorname{Kura}(n) m$, você não pode ficar falando assim para a gente, porque a gente sabe lutar muito bem." Depois, o outro sogro [isto é, o irmão do sogro] foi lutar com o rapaz.

Aí saíram de novo, de manhã, e foram jogar bola, pedrinha, de novo. Sempre que começavam, era com pedrinha, depois com bola. Com aquela pedrinha, queriam matar o rapaz, mas de sabia jogar pedra mesmo, quando a onça jogava a pedra, ele pegava-a mesmo. ("Aqui [na aldeia Kamayurá] havia pedra. Mas ninguém tinha coragem de jogar com ela; só com a bola. Mas no começo, aqui também jogavam. Se jogassem só bola, não tinha graça, não adiantava" - [esclarece o intérprete].) Aí jogou, primeiro o marido da onça com o rapaz, depois a mulher dele com o rapaz [isto é, primeiro a onça macho, depois a fêmea]. E como ele era bom, jogava bem.

Depois, $\operatorname{Kura}(n) m$ foi jogar contra o pai; e todas as onças jogaram com o rapaz. De manhã jogavam, e à tarde jogavam também, sem perder um dia. Às quatro horas foram lutar também, de manhã jogavam, de tarde lutavam. Primeiro foi o pai de $\operatorname{Kura}(n) m$, depois sua mulher, depois o resto das onças que havia lá. Aí foram jogar bola também, quando terminou a luta. Porque $\operatorname{Kura}(n) m$ ensinava ao rapaz, sempre, quando o pai saía; quando ele voltava, paravam de treinar, luta e jogo de bola.

Começou [o jogo] antes das onze horas, [até que] acabaram as flechas (que se davam quando ganhavam) ${ }^{151}$; aí pararam de jogar, porque não tinham mais com que pagar. Então Tarawi(n) foi lá na casa da onça e

o genro e a mulher deste tinham, normalmente, as redes armadas junto umas das outras, sem que isso implicasse falta de respeito Ou quebra da etiqueta prescrita nas relações sogro-genro (de evitação).

${ }^{151} \mathrm{Na}$ competição intertribal (há também treinos intratribais como o observado por E. Becker), os adversários têm direito a flechas e a todos os enfeites corporais usados pelo perdedor. Não deixa de ser curiosa a semelhança deste prêmio, do campo estreito a meio e alargado nos extremos, e das regras que impedem tocar com a mão na bola após o lance inicial, com o prêmio, campo e regras do "jogo de pelota" centro-americano. Ao que se poderia ainda somar a coincidência entre o papel importante desempenhado pelas onças no mito Kamayurá e o fato de ser um Templo dos Jaguares a presidir ao Juego de Pelota de Chichén Itzá. Vale também a pena comparar o caráter do jogo como o revela o mito maia-quiché de Hun-Hunahpú, Vucub-Hunahpú, Hunahpú e Ixbalanqué, com aquele de que se reveste no mito Kamayurá. Na série de provas a que são submetidos, principalmente os dois últimos, pelos Senhores de Xibalba, o jogo de bola é uma tentativa contínua de dar morte aos heróis - que acabam por vencer. Por fim, cabe dizer que Ixbalanqué se pode traduzir como "pequeno jaguar", (mas também "pequeno feiticeiro"). No entanto, não bastam estas aproximações para fundamentar uma hipótese difusionista (v. Recinos 1947:120-185). 
encontrou o rapaz e disse: "Se fosse eu, quando lutasse com você, ganhava." "É bom que você fale [isso]: eu não quero lutar com você."

Aí [Tarawi $(n)]$ chamou-o para lutar. Ele disse: "Não quero, eu quero é lutar com a onça." Então a onça pequena [Tarawi $(n)]$ convidou o rapaz para tomar banho, dizendo: "Então, companheiro, você está aí mesmo, companheiro." Tarawi $(n)$ disse ao rapaz: "Eu soube que você está aí, casado com a filha da onça." Chegaram ao rio, tiraram o inimo $(n)$ [ligaduras de algodão] de joelho e braço, e ficaram sentados, lá. Tomaram banho, e Tarawi $(n)$ disse: "Se fosse eu, ganhava de você." "Não, eu ganhava de você", disse o rapaz. Tarawi $(n)$ repetiu, e convidou para lutar. Aí foram lutar e a onça pequena ganhou mesmo, do rapaz, e disse: "Está vendo? Se eu fosse lutar com você, ganhava, e a onça te comia mesmo, naquela hora." Aí o rapaz falou: "É bom que você não tenha lutado comigo, se lutasse eu já estava comido." E Tarawi $(n)$ disse: "É bom mesmo, senão a onça já tinha comido você. Se fosse eu, a onça já tinha comido você, todas as lutas eu ganho.” Aí o rapaz ficou sem graça, só rindo, quando a onça pequena ganhou dele. Passaram dois dias e voltaram a jogar bola.

Aí foram embora, a turma da onça, e Tarawi(n) também, porque tinha vindo junto. Aí foram também, voltaram e foram de novo, para jogar, porque queriam matar o rapaz. Aí passaram cinco dias, voltaram para jogar bola; chegaram de tarde, entraram na casa de yakui e ficaram todos alegres, [e ali] dormiram.

(A turma da onça tinha raiva do rapaz, por ciúme do rapaz. Por exemplo, se eu casar com moça de Kalapalo, eles ficam com ciúme. Assim mesmo eles estão fazendo com o rapaz. [Este parêntese explicativo é do intérprete]) $)^{152}$.

Começou assim: o rapaz ganhou de todas as onças, aí de manhã saíram com bolinha de pedrinha também. Pararam ao meio-dia porque as flechas acabaram, porque cada um recebeu flechas [o intérprete indica o quinhão individual, fazendo o gesto de quem abarca um molho de flechas com ambas as mãos], porque todos tinham jogado direito, ganhado muito. À tarde a flecha acabou, cada um ganhou um monte de flechas.

"É, tem razão mesmo", disse a onça, "o rapaz é filho de minha irmã." Aí a turma da onça foi embora, dormiu três dias e voltou de novo. Chega-

\footnotetext{
${ }^{152}$ Se não bastasse o decorrer do mito, este parêntese do intérprete eliminaria quaisquer dúvidas quanto ao fato de haver consciência do antagonismo e hostilidade latentes nas relações do indivíduo que casa noutra tribo, com os membros do grupo que lhe cede uma mulher; o que, aliás, transparece em grau menor, e no seio do pequeno grupo de afins, nas tão citadas regras de evitação, quando se trata de casamentos intratribais. Verifica-se também como o jogo é visto: expressão e canalização ritualizada desses antagonismo e hostilidade.
} 
ram, bem de manhã, com um mundo de flechas, que todo o mundo trouxe, para ganhar.

Por último, foi o rapaz jogar com a onça vermelha, que queria matar o rapaz, e jogar com força. Mas o rapaz pegou logo a pedrinha. Aí o rapaz pegou aquela pedrinha e jogou lá no peito da onça vermelha, arrancandolhe o cabelo do peito. Por isso ela até hoje tem pouco cabelo no peito. Warakuni( $n$ ) foi quem arrancou o cabelo do peito dele [onça], por isso agora a onça vermelha tem pouquinho cabelo no peito.

Às onze, a flecha acabou. Descansaram pouquinho, aí começaram de novo, a jogar. Aí acabou, e foram embora, a turma da onça foi embora. Aí o rapaz disse: "Estou com medo já, não vou ficar aqui muito tempo, vou embora daqui." Porque todo o dia as onças vinham jogar com ele. Estavam querendo comer o rapaz. Aí começaram a jogar pedra, sempre que [se] joga bola tem de começar na [pela] pedra, depois a bola. O rapaz ganhou tudo, da onça, e a mulher dele ficou satisfeita, alegre.

Aí acabou a flecha e guardaram a bola. Saíram de novo [para jogar] e quando ficou bem de tarde, acabaram as flechas. O rapaz queria ir embora, porque estava com medo mesmo. E dizia isso, sempre, à mulher dele.

Acabou a história, está no fim.

[O intérprete acrescenta: "O rapaz foi embora de lá, porque estava com medo"]. 



\section{BIBLIOGRAFIA}

1938 ABREU, João Capistrano de. Os Bacaels. In: Ensaios e estudos. 2.ed. Rio de Janeiro, Soc. Capistrano de Abreu. P. 217-274.

1966 AgOSTINHO, Pedro. Kwarip, festa dos mortos; índios Kamayurá, Alto Xingu. Brasília, Universidade. (Tese de mestrado).

1968 Geografia e cultura no Alto Xingu. Geographica. Lisboa (12). Separata.

CÂMARA Jr. 1955, Joaquim Mattoso. A grafia dos nomes tribais brasileiros. Lista apresentada à II Reunião Brasileira de Antropologia, Salvador, 1955. Rev. de Antropologia. São Paulo, 3 (2): 125-132, dez.

1956 CARNEIRO, Roberto L. Slash-and-burn Agriculture; a closer look at its implications for settlement paterns. In: International Congress of Anthropological and Ethnological Sciences, V. Selected papers. Philadelphia, Univ. of Pennsylvania Press.

1956-1957 \& DOLE, Gertrude E. La cultura de los indios Kuikuros del Brasil Central. Arq. para las ciencias del hombre. Buenos Aires, 8 (2): 169-202 (Separata).

1961 Slash-and-burn cultivation among the Kuikuro and implications for cultural development in the Amazon basin. In: The evolution of agricultural systems in native South America, causes and consequences; symposium. Caracas, s.c.p. p. 47-67. Anthropologica supplement, 2). 
1951 CARVAlHO, José Cândido de Melo. Relações entre os índios do Xingu e a fauna regional. Rio de Janeiro, Museu Nacional. (Pub. avulsas, 7).

1960 CUNHA, Ayres Câmara. Entre os indios do Xingu. São Paulo, Liv. Exposição do Livro.

1964 DOLE, Gertrude. The development of Hawaiian Kinship nomenclature as exemplifeid by the Kuikuro; summary. In: Congresso Internacional de Americanistas, XXXV. México, 1962. Actas e memorias. México, s.c.p., v.2. p.95.

1955 FERREIRA, Jorge \& BALLOT, Henri. A expedição que não morreu. $O$ Cruzeiro. Rio de Janeiro, 27 (40): 6, 16 jul.

1950 GAlVÃO, Eduardo. O uso do propulsor entre as tribos do Alto Xingu. Rev. do Museu Paulista. São Paulo, 4: 353-368.

1953 Áreas culturais indígenas do Brasil, 1900-1959. Bol. do Museu

Paraense Emílio Goeldi; Antropologia. Belém (8), jan.

1964 \& SIMÕES, Mário F. Kulturwandel and Stammesueberleben am oberem Xingu, Zentral Brasilien. Volkerkundliche Abhandlugen. Hanover, Niedersachsisches Landesmuseum, (1). (Separata);

s.d. HARRISON, Carl Howard. Formulário dos vocabularies padrões para estudos comparatives preliminaries nas linguas indigenas brasileiras; língua Kamayurá, Apiap. Brasília, Universidade, Dep. de Lingüistica, mimeo.

1966 JUNQUEIRA, Carmen. A circulação de bens na sociedade Kamayurá, São Paulo, s.c.p. mimeo.

1960 KRAUSE, Fritz. Máscaras grandes do Alto Xingu. Rev. do Museu Paulista. São Paulo (12): 7-36.

1958 LÉVI-STRAUSS, Claude. Anthropologie structurale. Paris, Plon.

1950 a LIMA, Pedro. LIMA, Pedro. Os índios Waurá, observações gerais; a cerâmica. Bol. do Museu Nacional; Antropologia. Rio de Janeiro (9).

1950 b ___ Grupos sanguíneos dos índios do Xingu. Bol. do Museu Nacional; Antropologia. Rio de Janeiro (11).

1955 "Distribuição dos grupos indígenas do Alto Xingu". In: Congresso Internacional do Americanistas, XXXI. São Paulo. Anais. São Paulo, s. c. p., v. 1, p. $159-170$. 
1955 MURPHY, Robert \& QUAIN, Buell. The Trumai Indians of Central Brazil. Locust Valley, NY, J.J. Augustin. (Monog. of the Amer. Ethnol. Soc., XXIV).

1964 MYAZAKI, Nobue. Breves notas sobre a socialização da criança em duas tribos Aruake. Volkerkunde Abhandlungen; Beitrage zur Volkerkunde Sudamerika. Hanover, Niedersachsisches Landesmuseum (1): 204-222.

1953 NEWMAN, Marshall T. Anthropometry of the Umutina, Nambicuara, and Iranxe, with comparative data from other Northern Mato Grosso tribes.

Appendice. In: OBERG, Kalervo. Indian tribes of Northern Mato Grosso, Brazil. Washington, DC, Inst. of Social Anthropology. p. 128-135.

1953 OBERG, Kalervo. Indians tribes of Northern Mato Grosso, Brazil. Washington, DC, Inst. of Social Anthropology. (Pub. 15).

1965 OlIVEIRA, Adélia; AGOSTINHO, Pedro; AZEVEDO, Gilda. Relatório de viagem ao Alto Xingu, apresentado ao Departamento de Antropologia da Universidade de Brasília. Brasília, Universidade, Dep. de Antropologia, Datil.

1947 RECINOS, Adrián. Popol Vub; las antiguas historias Del Quiché. Trad. com uma introd. y notas. México, Fondo de Cultura Econômica.

1954 REUNIÃO Brasileira de Antropologia, I. Rio de Janeiro, 1953. Convenção para a grafia dos nomes tribais. Assinada pela maioria dos participantes. Rev. de Antropologia. São Paulo, 2 (2): 150-152, dez.

1957 RIBEIRO, Darcy \& RIBEIRO, Berta. A arte plumária dos índios Kaapor. Rio de Janeiro, s. c. p.

1956 SANTOS, Yolanda Lhullier dos. A festa do Kwaríp entre os índios do Alto Xingu. Rev. de Antropogia. São Paulo, 4 (2): 111-116.

1965 SCHADEN, Egon. Aculturação indígena; ensaio sobre fatores e tendências da mudança cultural de tribos índias em contato com o mundo dos brancos. Rev. de Antropologia. São Paulo, 13 (1-2), jun./dez.

1942 SCHMIDT, Max. Estudos de etnologia brasileira. Trad. de Catarina B. Canabrava. São Paulo, Cia. Ed. Nacional. (Brasiliana, GF, 2).

1965-1966 SCHULTZ, Herald, Lendas Waurá. Rev. do Museu Paulista. São Paulo, 16: 21-149.

1966 Brazil's Waurá Indians. National Geographic Mag. Washington, DC, 129 (1): 130-152, jan. 
1967 \& CHIARA, Vilma. A pá semilunar da mulher Waurá. Rev. do Museu Paulista. São Paulo, 17: 37-48.

1963 SHAPIRO, Warren. The institutionalization of sex antagonism. Dir. of Prof. Wagley. S. 1. p., dez. Datil. (Anthropology G. 4141).

1969 SILVA, Rosa Virgínia Mattos e. Notas de Campo. S. 1. p., s. c. p. Datil. 1963 a SIMÕES, Mário Ferreira. Relatório de excursão; situação atual das tribos do Alto Xingu e dos grupos marginais; estruturas demográficas e mudança cultural. Apresentação ao Museu Paraense Emílio Goeldi. S. 1. p., s. c. p. jul./set. Datil.

1963 b __. Os Txikão e outras tribos marginais do Alto Xingu. Rev. do Museu Paulista. São Paulo, 14: 76-101.

1967 . "Considerações prelimirares sobre a Arqueologia do Alto Xingu".

In: Programa Nacional de Pesquisas Arqueológicas. Brasil. Resultados prelimirares do primeiro ano, 1956-1966. Belém, Museu Paraense Emílio Goeldi. (Pub. avulsas, 6).

1940 STEINEN, Carl von den. Entre os aborigenes do Brasil Central. Trad. de Egon Schaden. São Paulo, Dep. de Cultura. (Separata da Rev. do Arquivo. São Paulo, 34-43).

1942 O Brasil Central. São Paulo, Cia. Ed. Nacional. (Brasiliana, GF, 3).

1970 VILLAS BOAS, Orlando e VILLAS BOAS, Cláudio. Xingu, os índios e seus mitos. Rio de Janeiro, Zahar.

\section{ÍNDICE DAS ESTAMPAS, FIGURAS E QUADROS}

Estampa 1 - Kwarìp

Estampa 2 - İrìvutsi(n)ng moko(n) aka(n)ng

Figura 1 - Desenho feito por Kwat no chão

Figura 2 - Aldeia celeste, das almas

Figura 3 - Bichos bravos da lagoa celeste

Quadro 1 - Número de variantes dos mitos e outras narrativas, por CLASSIFICAÇÃO LINGUISTICA e tribo (publicadas)

Quadro 2 - Correspondências das variantes kamayurá publicadas Quadro 3 - Dados relativos à recolha dos textos 


\section{NOTA FINAL}

O trabalho de campo foi apoiado por subsídios do Departamento de Antropologia da Universidade de Brasília, sob a direção do Prof. Eduardo Galvão (1965); do Laboratório de Arqueologia e Etnologia da Universidade Federal da Bahia, dirigido pelo Prof. Valentin Calderón (1966); e pelas facilidades devidas a Orlando Villas Boas, diretor do Parque Nacional do Xingu. O Urgent Anthropology Program, por intermédio dos Drs. Clifford Evans e Betty Meggers, facultou fundos para sua continuação (1966-69)

A preparação do manuscrito e decorrente trabalho de gabinete foi possibilitada por doações de D. Mariana Alvim e do Dr. Antônio Carvalho e Silva ao Centro Brasileiro de Estudos Indígenas, de Brasília (1970).

Foi importante a colaboração de Luiz Carlos Luz, e de Maria Luiza de Lavenére Bastos nos arranjos finais para entrega à imprensa.

Os desenhos são de Yanu(n)makakuma(n) (Sapai(n), Kamayurá residente na aldeia Yawalapitì, e as fotos, de materiais Kamayurá $(1964,1965)$.

Este livro terminou-se de imprimir, nas oficinas da Editora Beneditina Ltda., Salvador, Bahia, Brasil. A supervisão dos trabalhos tipográficos esteve a cargo de Benedito Jorge Miranda. Planejamento gráfico de Jacyra Oswald. Supervisão editorial de David Salles. Diretor do Núcleo de Publicações, David Salles. Coordenador do Centro Editorial e Didático, Valentin Calderón. Reitor, Lafayette de Azevedo Pondé. 



\section{ESTUDO PRELIMINAR SORRE O MITO DE ORIGENS XINGUANO. COMENTÁRIO A UMA VARIANTE AWETÏ}





\section{INTRODUÇÃO}

O texto Awetï que em 1965 obtivemos no Parque Indígena do (Xingu e adiante publicamos filia-se a uma tradição mais ampla, partilhada por todos os grupos xinguanos cuja mitologia se acha documentada. Sendo o principal mito do ciclo do Sol e da Lua (gêmeos e do sexo masculino), é também o de que maior número de variantes se conhece, todas coincidentes em suas linhas essenciais. Ficou, entretanto, demonstrado por um exame preliminar que apresentavam lacunas de maior ou menor extensão, saltos abruptos de um ponto para outro do mito, ou até para mito diferente, omissões de pormenor mais ou menos importantes, e ainda pequenas diferenças nos fatos ou no arranjo da sequência narrativa. Deixando de parte estes dois últimos casos - que só uma análise estrutural permitiria compreender cabalmente -, devem-se atribuir os restantes a fatores diversos.

Na maioria das vezes a recolha foi feita com auxílio de um intérprete, que traduziu, direta e intercaladamente ou a partir de prévia gravação, valendo-se de uma língua em cujo uso acha sempre dificuldades; com o mesmo óbice, noutras ocasiões a história foi contada em português. Ao que sabemos, só v.d. Steinen obteve sua documentação na língua original, e o mesmo pode ter ocorrido com Buell Quain, que confessadamente encontrou na barreira linguística uma limitação a seus estudos mitológicos. A experiência mostrou-nos que o intérprete indígena tende a simplificar o que ouve, como o atesta Laraia (1970:116), e o mesmo ocorre quando se trata de um relato direto em português.

Há também a considerar que a situação social em que se dá a interação informante-pesquisador difere muito daquelas em que normalmente se narram os mitos. No primeiro caso estão envolvidos dois indivíduos nos papéis principais (informante e antropólogo), e um terceiro, o intérprete, 
num papel secundário que pode existir ou não. Isto parece favorecer os cortes e saltos, e o encadeamento contínuo de mitos ou fragmentos de mitos sem nítida separação, indicando o estudo da coletânea waurá de Schultz que esse autor enfrentou a mesma dificuldade que nós. Dessa situação que foge aos padrões da cultura tribal, o básico é que apenas o informante assume papel ativo, que o torna em único responsável pela história, quando normalmente não é isso que sucede. Na "roda dos fumantes" Kamayurá, enquanto um fala e os demais ouvem, há frequentes interrupções e apartes, que explicitam, acrescentam, pedem esclarecimentos ou introduzem parênteses explicativos.

Resulta portanto a literatura xinguana uma literatura que é coletiva no elaborar-se como no exprimir-se, sendo esse caráter coletivo o que se perde nas entrevistas, com a consequente perda em sua riqueza e forma. O ideal seria obter os textos por gravação naquelas situações normais, que não são, entretanto, tão usuais quanto se desejaria. Aliás, se fosse esse o método seguido, e sendo impossível a repetição exata de uma dada situação concreta, ter-se-ia sempre uma gama infinita de pequenas variações. Assim, tornase válido apoiar a análise na documentação disponível, reconhecendo nela todos os defeitos de que padeça, desde que os fatores negativos sejam tidos em conta e se disponha de meios para compensá-los.

Tomando como foco deste comentário a variante Awetï do Mito das Origens, fizemos coincidir com os seus próprios os limites da comparação a exercer, cujo objeto foram os episódios que descreve ou a que faz alusão. Isto estabeleceu que seria estudada a parte do mito que se ocupa do Ancestral, do casamento de suas filhas com a Onça e do nascimento dos Gêmeos, e por fim da criação das tribos, o que significa que se deu especial atenção aos planos social, cultural, étnico e ecológico do universo xinguano.

Delimitado o âmbito da comparação, análise e comentário, extraímos da bibliografia pertinente e de nossos dados de campo todos os textos que correspondessem ou complementassem a variante Aweti, o que levou a alargar os limites finais da comparação para incluir a história da comemoração do primeiro Kwarïp ${ }^{1}$, essencial à compreensão do mito. Reunimos assim 26 textos ou fragmentos, cuja extensão não é uniforme, depois submetidos a uma classificação e crítica externa e interna, que lhes determinou o exato valor e o grau de confiança merecida.

\footnotetext{
${ }^{1}$ Kwarip são efígies feitas de troncos, que representam os mortos em sua festa. Por extensão e graças à influência civilizada, esse é hoje o nome da festa dos mortos. Antes era Torïp. Ambos os termos são Kamayurá, diferindo nas outra, tribos. Na transcrição das palavras indígenas, ao valor fonético de nosso alfabeto acrescentamos as seguintes convenções: [’] oc1usiva glotal: [ts] africada alveolar surda: [ph] fricativa bilabial surda: [ng] nasal velar sonora; [i] vogal alta central fechada não arredondada; [.] alongamento da vogal; [w] e [y] são semivogais.
} 
Esses 26 documentos provem de 7 grupos tribais, sendo 1 dos Aweti, 11 dos Kamayurá, 1 dos Yawalapití, 5 dos Waurá, 2 dos Kalapálo, 3 dos Bakaíri e 3 dos Trumaí, e consideramos válida a amostra por incluir quase todas as famílias e troncos linguísticos representados no Alto Xingu, Tupi, Aruak, Karib e Trumaí. Os Suyá, grupo marginal e de filiação Jê, não figuram no material utilizado. Por coincidencia e sorte, os textos distribuem-se ainda de uma forma que obedece às principais subdivisões locais desses troncos linguísticos. As línguas Awetï e Kamayurá diferem bastante, considerando-se seus falantes mutuamente ininteligíveis. O Aruak admite duas línguas ou talvez dialetos distintos, por um lado Mehináku e Waurá, por outro Yawalapití, e o mesmo ocorre com o Karib, que se divide em Bakaíri (Oriental e Ocidental) e Nahukwá (Kuikúro, Kalapálo e NahukwáMatipú). Quanto aos Trumaí, sabemo-lo um grupo sob este aspecto isolado, e em vias de extinção, que só há pouco foi linguisticamente estudado. Isto nos leva à convicção de que dita amostra é o bastante representativa da tradição alto-xinguana para que os resultados e conclusões a que se chegar possam ser, com relativa segurança, generalizados às tribos cujos mitos não se possuem.

Foram os textos classificados por filiação linguística e tribo, e depois ordenados cronologicamente pela data de sua coleta, de modo a tornar o mais gradual possível a transição de um a outro componente da amostra. Cada variante foi identificada por um número de classificação decimal, no qual a primeira casa da esquerda indica a classificação linguística, a seguinte a tribo e a última a posição cronológica do documento na série correspondente à tribo. A essa casa sucede por vezes uma letra minúscula, de cujo significado diremos adiante. O Quadro 1 reúne as demais referências indispensáveis sobre cada variante, e obedece aos princípios acabados de expor; entretanto, para simplificar as notas remissivas, no corpo do trabalho eliminamos os pontos que separam as casas decimais, mantendoos, ao mesmo tempo, no Quadro n.ำ1.

Certos grupos de fragmentos, complementares entre si se considerados na sequência linear do mito, foram reunidos para reconstituir variantes que, sendo até certo ponto artificiais, não são intrinsecamente inferiores, pois aquela reunião usou sempre fragmentos colhidos pelo mesmo investigador, na mesma época e na mesma tribo. Sendo possível, houve também a certeza de que informante e intérprete foram também os mesmos, e, em todos os casos, os fragmentos assinalaram-se com as minúsculas de que falamos. Resta a ressalva de que, enquanto as variantes $121 \mathrm{ab}, 126 \mathrm{ab}$ e 411 abc são produto de uma construção, a variante 322 ab resulta da supressão de várias partes do original: cortamos ao mito principal de Keri e Kame publicado por v.d. Steinen, para nos manter nos limites pré-esta- 


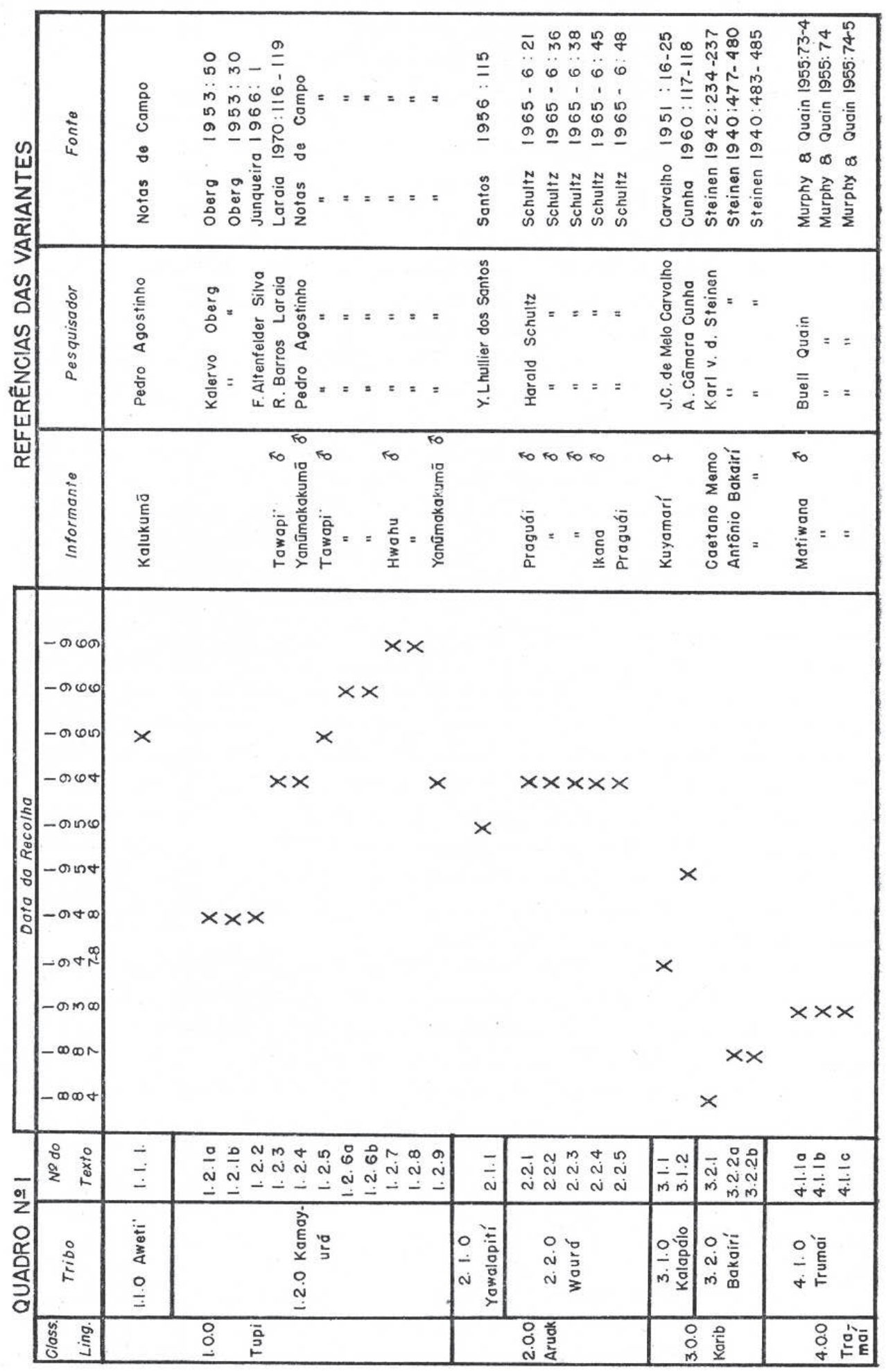


belecidos, os episódios do roubo do sol, do sono, da rede, da troca do céu pela terra, do fôgo e dos rios.

\section{DOCUMENTAÇÃO}

Devemos a v. 111 a Kalukumã, que, considerado velho ${ }^{2}$ e o melhor narrador por seus companheiros de tribo, encontra considerável obstáculo no uso do português, vindo isto refletir-se na qualidade de seu texto, umas vezes bastante prolixo, outras quase alusivo ou esquemático: daí certo desequilíbrio entre os episódios, como se vê gràficamente no Quadro 2. Tendo viajado bastante, o que é comum, pelas tribos vizinhas, estabeleceu também contacto com a civilização nos postos do extinto S.P.I, e, mais recentemente, do Parque Indígena do Xingu. Tudo indica que conheceu missionários, talvez os protestantes instalados no sul da bacia por volta de 1926, ou que tênues elementos cristãos lhe chegaram, quem sabe filtrados através dos Bakaíri ocidentais, catequizados desde 1820. A possibilidade de que isso tivesse ocorrido no P.N.X. é remota, dada a inexistência, aí, de proselitismo religioso. Isto é corroborado pelo fato de os Kalapálo em 1947-8 já equipararem Deus ao Sol, como ele equipara o Ancestral (Mamutsinĩ) a Cristo.

Dos Kamayurá, a profusão é maior. Os fragmentos 121 ab apresentam relativa pobreza e contradições com o resto da tradição xinguana, atribuíveis a dificuldades de comunicação, e talvez a uma antiga subtradição tribal (Tupi?) em vias de desaparecimento. O texto 122, pelo contrário, e apesar de muito reduzido, concorda com os demais e pode ser aceito sem qualquer reserva. A v.123 é, pela extensão e pormenor, de qualidade bem superior, e contou com a colaboração de excelentes informante e intérprete; a de número 124 é curta, e foi contada pelo índio que serviu de intérprete à anterior, muito habituado com antropólogos e linguistas. Em seu âmbito, é bastante sintética, mas tem o mérito de evidenciar, nos traços essenciais, o sistema de classificação étnica indígena. As seguintes, 125 e 126, obtivemo-las na aldeia Kamayurá, do mesmo Tawapï que forneceu a v. 123, e o cotejo das três exemplifica bem o grau de variação que um mesmo indivíduo pode alcançar em suas narrativas: enquanto 123 finaliza com a dádiva do fogo às tribos e a dispersão destas, 125 fala brevemente da primeira festa do Kwarïp, e 126 salta, brusca, do episódio da nominação, dos Gêmeos para o de Savuru assassinado pelas ariranhas, e, logo, para o do roubo da água.

\footnotetext{
${ }^{2}$ Terá aproximadamente 60 anos.
} 
Estes saltos, frequentemente desnorteantes numa variante isolada e lacunosa, situam-se e ocupam lugar próprio quando a comparamos a outras variantes e mitos. A mais longa e pormenorizada é a v. 127, que, calando-se quanto a Savuru e ao roubo da água, põe o Kwarïp como fêcho do principal mito do ciclo dos Gêmeos, ciclo este, seja dito, ainda incompletamente registado. O episódio de Savuru, incorporado à v. 126, só poderia ocorrer após a nominação dos Gêmeos, quando, passado o Kwarïp, atingem o status de adulto: pois aquele episódio está relacionado à aquisição de mulheres pelos dois. Isto exemplifica como, por trás da interrupção aparentemente absurda, existe uma razão coerente com o todo mítico, que, na comparação, se elucida graças a indícios internos e à evidencia etnográfica externa. Permitindo isto a reconstituição de uma sequência diacrônica original do mito, assunto a que voltaremos ao expor os métodos empregados. Ainda quanto à v. 127, cabe notar que segue de perto as v.123, 125 e 126, devendo-se isso a ter sido relatada por Hwabu, que se provou informante mais rigoroso que seu falecido pai, Tawapi, embora de menos vasta sabedoria. Por suas qualidades intrínsecas e pelas de Hwabu, consideramos esta variante como a mais promissora e adequada a servir de referência na comparação.

O texto 128 é um pequeno mito independente da variante de referência, de que lançamos mão como parêntese intermediário entre as origens do Ancestral e o momento em que começa a fazer gente de troncos, pois revela como naqueles tempos a terra era pequena e foi preciso aumentá-la para comportar os homens. O caso da v.129 é de outro gênero, porque serviu numa comparação paralela à principal, sintetizando a história da nominação dos Gêmeos, cujas etapas se acham dispersas pelas outras variantes.

A tradição Yawalapití acha-se presente por um único fragmento (v.211), que quanto à autenticidade é bastante duvidoso. Além de dar o nome do Ancestral, Maivotsin, de uma forma muito próxima do Kamayurá Mavutsinĩ), quando em Yawalapití ele é Kwamuti, assemelha-se tanto às variantes desse grupo Tupi que se pensa numa interferência, não de cunho aculturativo como entre os Bakarirí (Steinen 1940:468), mas no ato de coleta.

Dos Waurá temos cinco documentos, cabendo ao de número 221 o mérito de contar a maior sema de informações sobre o nascimento do Ancestral, de que só há breves notícias nas v. 111 e 222, e alguns dados elucidativos nas v. 321 e 322 ab. No restante, a v.221 acompanha 127 com pequenas alterações na sequência dos episódios. Apesar de fragmentária, os elementos da v. 222 coincidem com os das outras, e a seguinte, 223, limita-se à distribuição dos bens culturais pelas tribos, mas de um modo muito pormenorizado e quase idêntico ao da v. 111. Na v. 224 deparamo- 
nos com a fusão de dois mitos, ou antes, partes de mitos, uma relativa ao nascimento dos Gêmeos e ao seu conflito com o pai, e a outra ao parricídio das ariranhas, que se liga à historia de Savuru. Essa fusão deveu-se mais ao etnólogo que ao índio, que, como o anotador do texto bem o advertiu, avisou entre um e outro componente: "Acabou. Então tem outro". Isto bastaria como justificação para desmembrar o texto, como o fizemos, retendo apenas o que nos era necessário. A última variante Waurá é a 225, que se ocupa do Kwarïp da mãe dos Gêmeos de uma forma tal que complementa, com exatidão, os informes das v. 125, 126b e 127 em todos os passos da festa. É esta, convém notar, a melhor, e diríamos perfeita, descrição indígena que temos desse cerimonial.

Da tradição Kalapálo contamos com apenas dois textos, de muito desigual qualidade. A v. 311 trata do que chamaremos parte nuclear do mito (v. Quadro 2), acompanhando, via de regra, a v. 127, e figura entre as melhores da amostra. Já a v. 312 levanta sérias suspeitas sobre sua procedencia e fidedignidade, dado o caráter precário da obra de Cunha (1960), onde se misturam sem método dados que, apresentados como Kalapálo, parecem na verdade de diversas procedencias. É o que se dá com o nome do Ancestral, Kwatïngï em Kalapálo e não Mavutsinĩ), e com as próprias características internas da variante em questão, muito mais coincidente com as Kamayurá do que com a 311, esta comprovadamente Kalapálo. A semelhança disto com o que se viu quanto ao documento 211 faz pensar que nas duas ocasiões prevaleceu a tradição mais divulgada entre os civilizados, pela frequente interação destes com os Kamayurá, devida à proximidade geográfica.

As versões mais antigas do mito são as registadas por v.d.Steinen entre os Bakairí, no século passado. A 321 não é exatamente um mito, mas antes uma série de dados mitológicos organizados após a primeira viagem do sábio alemão, e neles o resultado de longo contacto com o branco está bem patente na identificação do Sol (Keri) com o Imperador (Pedro II), da tia ou avó dos Gêmeos, Ewaki, com Eva, e do Ancestral (Kamuschini) com Adão. De valor informativo muito superior é a v. 322 ab, da qual pelas razões já expostas só retivemos as partes inicial e final; mas, se a compararmos à v. 127, veremos que relativamente a esta é quase esquemática, sem perder, contudo, as linhas essenciais do mito. Note-se que, aliás, é impossível a comparação do fragmento 322b com outros textos, por conter toda uma série de acontecimentos que lhe são únicos.

Dos Trumaí há tão somente os exíguos fragmentos publicados por Murphy e Quain (1955), e, como não tivemos acesso ao manuscrito deixado pelo último, ignoramos se essa exiguidade se deve a seleção praticada 
por Murphy ao apresentar os materiais, ou à falta de dados de campo. Isto não é de excluir, por causa das dificuldades linguísticas sofridas pelo pesquisador, e de sua prematura saída da aldeia Trumaí. Cabe esperar que venham à luz os textos há pouco recolhidos pela etnolinguista Aurora Monod, para que se possa penetrar melhor nesta tradição, que levanta interessantes problemas na esfera da mudança cultural, pela mobilidade, precário ajustamento e recente chegada da tribo à região. Em 1938, época da pesquisa de Quain, coexistiam nela dois mitos de origens, um evidentemente que lhe era próprio, e outro, de cunho xinguano, muito chegado ao dos Kamayurá, com os quais era constante e intenso o intercâmbio.

\section{MÉTODO}

Classificados e avaliados os textos, na abordagem que adotamos e visando recompor o quadro em que se situa nossa variante Awetï, valemonos da comparação sistemática de todas as variantes compiladas. Fizemolo reduzindo-as a unidades mínimas comparáveis, que, inspiradas nos mitemas de Lévi-Strauss (1958: 227-255), não lhes são contudo identicas por ficarem, achamos, num nível inferior de abstração: muitas de nossas unidades mínimas poderiam ser refundidas num mitema, que, indispensável se uma análise estrutural fosse o objetivo, seria por demais sintético para o cotejo termo a termo que quisemos efetuar. Com ele se podem superar, ao menos parcialmente, as lacunas encontradas em cada variante, e estabelecer uma diacronia global das ações míticas. Esta, sendo uma reconstrução possível, não será porventura única, mas foi a que aflorou da manipulação rigorosa das unidades mínimas, e de virtualidades inerentes à própria sequência do mito, seja considerado nas suas variantes individualmente, ou nelas combinadas entre si. Graficamente, o Quadro 2 demonstra como essa combinação se processa, e como as lacunas vão sendo recobertas por outros textos, de forma tal que a cada interrupção a narrativa é retomada sem solução de continuidade. Emerge assim um arque-mito de que participam todas as unidades mínimas de todas as variantes, na reconstrução de um hipotético texto arquetipal, e não apenas as de maior frequência relativa.

Para que o pudéssemos fazer, elegemos como variante de referência ${ }^{3}$ a de n. ${ }^{\circ} 127$, por ser a mais contínua e elaborada; mas, não o sendo de

${ }^{3}$ Como nas unidades mínimas, inspiramo-nos aqui no uso de um mito de referência por Lévi-Strauss (1964). 
modo absoluto, houve recurso a outras variantes sempre que nessa se apresentavam falhas. Usaram-se então de preferência as que lhe eram mais próximas, adotando-se como critério de proximidade a tribo, o informante, o intérprete e o pesquisador envolvidos, e ainda a data da pesquisa de campo: isso naturalmente obrigou a que a referência fundamental fosse a tradição Kamayurá. Não foi ela, entretanto, a única, pois por vezes faltoulhe a minúcia necessária, ou, simplesmente, inexistiu, como no caso das origens do Ancestral, e das festas alua e imeo (v. 322b). No gráfico, um traço une as variantes que alternativamente serviram de referência, e que foram assinaladas com asteriscos a partir do momento em que funcionaram como tal. Na questão da atribuição dos bens culturais às tribos, houve uma referência para cada tradição tribal, porque estas divergem entre si o bastante para exigir organização em separado.

As unidades mínimas foram transcritas em fichas, depois arranjadas de forma a se corresponderem de variante a variante, e os resultados passaram a tabelas em que os textos ficam em colunas verticais, e as unidades mínimas comparáveis e correspondentes em linhas horizontais que vão de coluna a coluna. A estes grupos de unidades mínimas foi dado um "número de entrada", num total de 723 entradas que compõem o arque-mito e incluem 1.360 unidades efetivamente cotejadas. Se, por hipótese, todas as variantes se igualassem termo a termo, para as 723 entradas teríamos nada menos de 15.183 unidades com que lidar: isto evidencia que o mito encerra uma virtualidade de informação muito superior à expressa em qualquer de suas manifestações ou variantes, e implica que só o seu conjunto é seguro objeto de análise. Sendo praticamente ilimitadas as variações possíveis, por muito prováveis que sejam serão sempre provisórias as conclusões obtidas. Estas, aqui, serão procuradas a partir do conteúdo mais evidente do mito, e portanto de seus níveis superficiais, reservando os de maior profundidade para posterior análise estrutural.

Reduzindo as tabelas componentes do arque-mito a dimensões compatíveis com um artigo, redigimos um "mito" que as acompanha fielmente, subdividindo-o em subtítulos que simplificam a referência ao Quadro 2. Nessa reconstrução, junto ao subtítulo está anotado o número de sua variante de referência, e, quando intercalações e complementos foram necessários, encontram-se assinalados pelo número da variante, anteposto ao texto introduzido. Vindo no início do parágrafo esse número abrange-o todo, exceto se outros entrarem em sequência. Neste caso de parágrafos compostos, as indicações valem para cada frase ou período. Parêntesis exigidos pela reconstituição ou ditados pelos informantes receberam o sinal próprio, e seguem-se colchetes à leitura da variante de referência, sempre que desta se apresentam divergências. 


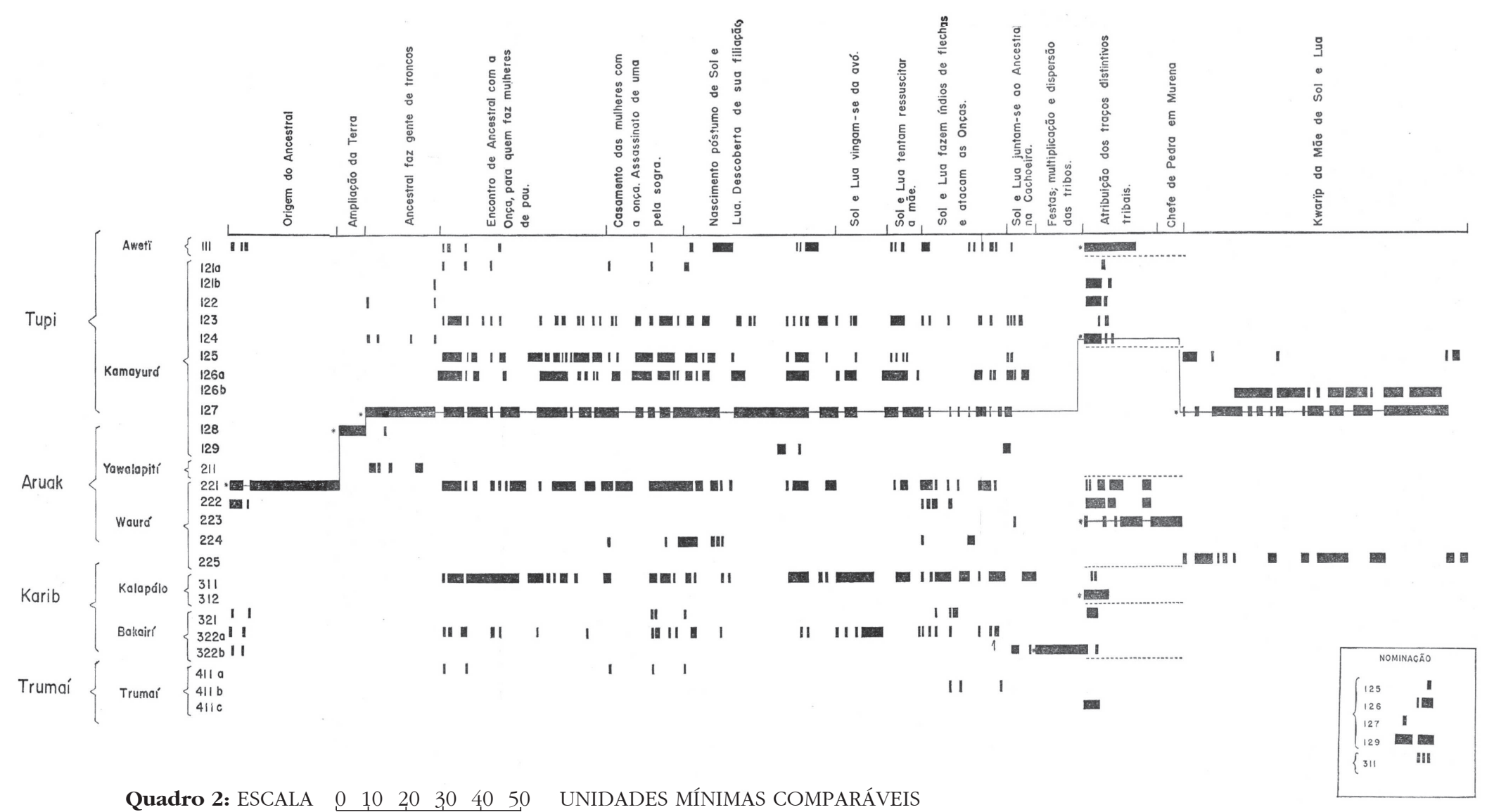

Quadro 2: ESCALA $\quad 0 \quad 10 \quad 20 \quad 30 \quad 40 \quad 50$ UNIDADES MÍNIMAS COMPARÁVEIS

Comparação e combinação sequencial das variantes. Tabela simplificada. Em destaque: mito da nominação

do Sol e Lua. I: ponto de inserção, na variante 322, dos seguintes mitos: roubo do Sol; rêde e sono; troca do céu pela terra; fogo; rios.

As linhas pontilhadas separam diferentes tradições tribais no episódio da atribuição dos traços distintivos. 


\section{IMPLICAÇÕES HISTÓRICAS}

Só de leve tocaremos aqui nos problemas de ordem histórica que o estudo suscitou, e que mereceriam melhor atenção se o espaço o permitisse. Bastará dizer que se distinguiram na tradição xinguana três subtradições geogràficamente localizadas, uma meridional e as outras setentrionais, a oriente e ocidente. O núcleo do mito é bastante homogêneo, do encontro do Ancestral com a Onça até ao conflito entre ela e os Gêmeos, e é nas partes que o antecedem e sucedem que se identificam as diferenças diagnósticas das subtradições, especialmente no que tange à criação das tribos e sua distinção. A subtradição meridional é a dos Bakairí Ocidentais, enquanto a norte-oriental abrange os Kamayurá, e os Trumaí secundàriamente. Não fossem as reservas que fizemos às v. 221 e 312, incluiríamos nela também os Yawalapití e Kalapálo, mas só novos textos, conseguidos com maior critério, poderão decidir, sobretudo quanto aos últimos: porque a v. 311 pouco ajuda, cingida que está àquela parte do mito que chamamos nuclear, embora faça pensar numa tradição tribal parecida, mas não identica à dos Kamayurá. Por fim, a tradição norteocidental acha seu melhor exemplo nos Waurá, e, difundida a partir deles ou dos extintos Kustenáu, atinge a sudeste os Aweti.

A questão das relações deste mito com os de outras áreas e grupos linguísticos foi discutida anteriormente por Laraia (1970), que concluiu pela sua filiação à mitologia Tupi-Guarani, e especialmente à dos Apopokuva, Tembé e Tenetehara. Se um parentesco é realmente inegável, como o demonstra também o exame das variantes estudadas por Métraux (1928), certas discrepâncias entre elas e as que nos interessam indicam que o assunto mereceria ser reconsiderado. O tema da "noiva de pau" recorre, por exemplo, entre os Warrau, os Cubeu e os Makuxí, o que aponta para passadas ligações históricas com a área norte-amazônica, e especialmente com grupos de Roraima e das Guianas. Não seria aventurado supor que seja essa uma contribuição Karib ao mito do Xingu, onde esse tronco linguístico era, em 1887, o demogràficamente mais importante. Não se pode no entanto ignorar que esse mesmo tema reaparece entre os Paresí, que são Aruak e tiveram contactos com o Xingu, e entre os Tacana bolivianos (Roquette Pinto 1938: 133-4; Levi-Strauss 1966:182-190). É de notar que essa variante Paresí se afasta dos outros mitos de origem dessa tribo, que seguem um modelo de emergência, mas, como de momento sairíamos do caminho traçado, sobre isto voltaremos. Outros paralelos, ainda, podem ser encontrados em grupos hoje mais ou menos geogràficamente próximos do Alto Xingu: é o caso Kumãpari, que cria os homens de hastes de flechas, entre os Yurúna 
e Xipáya, e dos rituais pelos últimos dedicados a efígies humanas feitas de troncos (Nimuendaju 1948:241). Mas, dada a recente chegada dos Yurúna à região, seria precipitada qualquer conclusão.

Esta incerteza quanto a efetivas trocas entre a mitologia xinguana e a de alguns de seus vizinhos ocidentais e setentrionais, não subsiste quando nos viramos para o sul: referimo-nos especificamente à identidade entre o Mito de Origens xinguano e o dos heróis bororo Bakororo e Itubore, pois as correspondencias são quase totais, sobretudo com a subtradição meridional do Xingu. Como se há de recordar, esta é a dos Bakairí Ocidentais, entre os quais parece ter havido uma tendencia a transmitir matrilinearmente os conhecimentos míticos: "Antônio aprendera todas as lendas por intermédio de sua mãe, declarando-me que assim acontece em regra" - é o que diz v.d. Steinen (1940:467) ${ }^{4}$. Ora, este Antônio Bakaíri que foi informante do etnólogo alemão, foi também casado com a legendária Rosa Bororo, que o acompanhou para o Rio Paranatinga em 1888 (Schmidt 1947: 18-19). Não é impossível que outras mulheres Bororo tivessem anteriormente seguido a mesma sorte, por meios pacíficos ou não, dada a contiguidade de territórios, e assim sendo, teria sido relevante seu papel como agentes de difusão; não só para os Bakaíri, mas talvez para algum grupo Aruak já desaparecido, pois veremos que há base para essa suspeita.

O mito Bororo é coerente com a organização dual da tribo, o que seria indício de se originar daí em sua atual forma particular, e entre os Bakaíri persiste no mito o esbôço de uma divisão em "metades", não mais agora subdividindo a tribo, mas agrupando todas as tribos em dois blocos. Na mitologia Bororo cabe a Bakororo o oeste e a Itubore o leste, e na dos Bakaíri, os povos de ocidente foram criados por Kame (Lua) e os de oriente por Keri (Sol). Mais ao norte, já na bacia dos formadores do Xingu, essa classificação bipartida em ocidentais e orientais desaparece, mas outra se lhe substitui, considerando dois grupamentos opostos, xinguano e nãoxinguanos, como teremos oportunidade de o demonstrar.

Tudo isto, se nos sugere os Bororo como centro de difusão imediato de uma das principais parcelas do mito xinguano, permite também como hipótese mais provável a de que sua difusão se fez para o norte, onde teria recebido dos Karib o tema da "noiva de pau", que falta por completo às variantes Bororo e é onipresente nas xinguanas.

Sendo as contribuições Bororo e Karib fundamentais na tradição que estudamos, não se pode, por outro lado, ignorar um elevado número de

\footnotetext{
${ }^{4}$ Haveria uma têndencia a transmitir matrilinearmente a tradição mitológica entre os Karib xlnguanos? Carvalho recolheu seu texto, também, da boca de uma mulher. V. Quadro 1.
} 
antropônimos, a atestar a dos Aruak na sua formação. Muitos exemplos poderiam ser aduzidos, mas basta que será talvez o mais interessante. Os dois heróis Sol e Lua figuram na variante Bakairí 322 com os nomes de Keri e Kame, que não são vocábulos Karib, mas Aruak, como bem o notou v.d. Steinen (1940: 467-8). Na língua em que foi recolhido o texto, a forma correta teria sido Tschischi e Nuna, mas não fica aqui a questão, porque ao adotarem os dois termos para seus personagens, os Bakaíri inverteramlhes o significado, uma vez que em Aruak Sol é Kame e Lua, Keri. Pertencendo à divisão oriental criada por Keri, que sendo Lua tem o papel secundário nos mitos Aruak, os Bakaíri etnocêntricamente passaram a considerálo Sol, e, mantendo-o como criador de seu grupo de tribos, deram-lhe o lugar principal no mito. Esta tendencia etnocêntrica é geral no Xingu, no sentido de atribuir à sociedade do informante o lugar central nos acontecimentos míticos, e a adoção de termos alienígenas pelos Bakaíri Ocidentais tem uma implicância cronológica importante. Ela permitiria supor uma área Bororo-Aruak de difusão continua do mito, anterior à intrusão dos Karib e talvez da "noiva de pau" - o que está de acordo com o que se sabe dos movimentos migratórios locais (v. Galvão e Simões 1965: 14-19).

Tendo acrescentado estas observações à discussão de Laraia sóbre a influência Tupi-Guarani na mitologia xinguana, gostaríamos de frisar que entre nossas conclusões e as suas não há incompatibilidade, mas antes complementaridade, uma vez que Levi-Strauss (1964:151) considera o mundo mítico Bororo profundamente devedor ao dos Tupi. Fica, ainda, em aberto o problema do contributo, Tupi, dos Kamayurá e Aweti ao patrimônio comum. Aos primeiros parece dever-se, de original, a maior importância do Ancestral na criação e classificação das tribos, e o mito da ampliação da terra: nas outras tradições tribais, quem as cria e classifica são os Gêmeos, e sobre a terra nada descobrimos.

Dos Trumái, de baixo prestígio, mal ajustados ao convívio intertribal e ràpidamente depopulados por guerras e epidemias, nada parece haver passado ao Mito de Origens; pelo contrário, nosso conhecimento fragmentário mostra que, para a existência dos homens, duas explicações coexistiam. Uma, tipicamente xinguana, e a outra com certeza do acervo Trumaí, na qual o Sol, Ateble, faz o antepassado deles pela transformação de um peixe, o que responde, sem dúvida, pela crença dos outros índios, de que os Trumaí seriam "animais aquáticos" (Steinen 1940:453). Disto tudo, importa reter que, com a exceção apontada, todos os troncos linguísticos presentes deram sua parcela ao mito que lhes é comum, da mesma forma que a intensa aculturação ali gerou uma cultura pràticamente uniforme. 
Calcular a profundidade cronológica absoluta de um mito é sempre tarefa difícil, senão inviável, mas um leve indício permite-nos tentá-lo. Ao delimitar os dois blocos ocidental e oriental, a v. 322 (colhida em 1887) arrola no de oeste os Suyá, que desde 1884 foram encontrados no SuyáMissu, isto é, no extremo norte da bacia xinguana. Antes disso, eles localizavam-se a sudoeste da posição atual e a noroeste aproximadamente dos Bakaíri Ocidentais, o que justifica sua filiação ao grupo de Kame, sabendose que migraram do Rio Verde para nordeste sob pressão dos Bakaíri, aliados aos que, mais provavelmente Xavante, v. d. Steinen chama Kayapó. Esse movimento é situado pelo mesmo autor (1940:501) no primeiro quartel do século XIX, e marcaria a data mínima admissível para a existência, em sua forma presente, do mito que nos ocupa. Sendo de 1969 os textos mais recentes, veríamos um período de 144 anos coberto pela tradição tal como a temos, e sua marcante unidade, quer temporal, quer especial, atesta, ao nível ideológico da cultura xinguana, um ritmo de mudança muito lento. As diferenças resultariam do processo de difusão e aculturação, e dos anos decorridos entre o registro das múltiplas variantes. Dos oitenta e cinco após a primeira viagem alemã (1884), setenta se passaram antes de novo documento ser obtido, se excetuarmos os fragmentos devidos a Buell Quain. Mais recente ainda é a versão Awetï que agora transcrevemos.

\section{VARIANTE AWETÏ}

O pai de Mamutsini era o morcego (Tatsia)5, que teve relações com uma mulher de pau-preto. Disso nasceu Mamutsini em Aluaku, ainda de noite. Ainda pequeno [com mais ou menos o tamanho de uns 8 anos], veio para Murena. Quando cresceu, voltou e foi buscar a mãe para junto de si, para o Murena.

Resolveu Mamutsini fazer arco de pau preto, e no mato encontrou-se com Itsumari, capitão das onças, e ficou com medo. Foi roubar o arco-íris, e a onça viu.

Com medo, Mamutsini prometeu mulheres ao capitão das onças, suas filhas. "Se você quer vai lá buscar, para ser sua mulher, traz para cá."

Aí, com pau preto, trabalhou e fez mulheres para a onça.

Itsumarï veio buscar as mulheres e levou-as, as duas [o inf. mostra 2 dedos e diz: três]. Aí Itsumarï copulou. Aí nasceram os dois netos, mas a mãe deles morreu. (Eram Kwat (Sol) e Ta.tï (Lua). Os irmãos foram tirados da barriga da mãe e levados, pequenos, numa mala, para Murena. (Mamutsinĩ é Jesus).

\footnotetext{
${ }^{5}$ Os parêntesis são do informante os colchetes, nossos.
} 
Kwat chorava dentro da mala. O avô soltou-o; ele foi brincar na água. De noite, dormiu. Cresceu, o pai veio olhá-lo: Kwat escutou falar e chamou-o e Itsumarï gostou. Kwat contou a Mamutsinĩ e ele não gostou. Aí Kwat e o irmão choraram, pela morte da mãe, no mato. E a mulher de Mavutsini disse: "Mãe o que?" - deu-lhes beiju de pau. Kwat comeu, e depois bebeu mingau da terra que se usa para fiar [tabatinga].

Kwat cresceu e foi caçar passarinho. Matou um, e o passarinho conversou com ele: "Essa não é tua mãe, é tua avó. Tua mãe a avó (mãe da onça) matou. Mamutsinĩ tirou-te da barriga dela e pôs na mala".

Kwat veio, chorando. "Mãe, cade beiju, mãe, cade mingau, mãe?" "Aqui tem". "Não. Isso é terra e pau. Minha mãe morreu." Ai Kwat fez o porco pondo-lhe [o seu próprio] cabelo. À noite, Kwat entrou no caitetu e foi comer o arroz de Mamutsini no mato, e a mandioca também. Todos os bichos comeram. De dia, Mamutsini viu tudo comido, gritou, e os bichos correram.

Kwat chorava. Mamutsini veio e deitou-se na rede, bravo, porque o neto lhe comera o arroz. Mamutsini foi pegar beiju, deu-o ao neto, que comeu. Dormiu, e depois foi brincar na água; o pai dele veio, ficou olhando. Aí pôs um soco e um gambá em casa.

Kwat pediu, e a onça fez-lhe flechas, que são as avós de todos os índios que moram no Xingu. Flecha ü̈p é do Xingu [ubá]. Os Jurúna são netos da flecha tempẽ 'ãndu [taquarinha] e os Cajabi e Suyá (índios bravos) também 6 . O pessoal da onça é que as fez, mas Kwat ficava com elas; muitas. Primeiro pegou flechas xinguanas, depois as dos índios bravos.

Kwat espetou as flechas no chão, na aldeia de Itsumari), em círculo.

A noite foi falar com as flechas: "Amigo, vocês está brigando esse pai, pessoal desse pai” [i. é., mandou-os atacá-lo].

Fez então, à noite, a carabina que é avó dos caraíbas, mas ela não brigou, ficou na mão de Kwat. Quando as flechas (xinguanas) atacaram, ele apanhou o pai pela mçao e mandou-o para o céu: curvou uma pindaíba, sentou o pai nela, agarrando-o (porque o pai não queria ir) por uma mão, e atirou-o para o céu (ïwapit); sentou também a anta, o veado: aí a onça no céu está comendo anta e veado. Aí as flechas, todas, mataram as onças.

Kwat fumou, e a fumaça disse-lhe onde estava sua mãe, morta. Ele chamou-a, "Mãe, mãe, mãe... Levanta, mãe". Ela disse: "Como é que é, meu filho? Estou morrendo". Kwat chorou, chamando a mãe, e ela não veio. Ele mandava-a levantar, e ela não obedeceu. (A língua de Kwaté Kutanaphu) ${ }^{7}$. Aí a mãe dele morreu; ele chorou, mas não adiantou. Aí as flechas-índio vieram.

\footnotetext{
${ }^{6}$ São os materiais respectivamente usados por essas tribos na fabricação de suas flechas.

7 Kutanaphu, i.é, Kustonau, grupo Aruak hoje extinto. Situava-se em 1884 no R. Batovi, a montante dos Waurá (Steinen 1942. mapa anexo).
} 
Trouxeram mingau, e leite, pinga. As flechas disseram que não queriam pinga, era sujo. Kwat disse: "Como chama [o que] você quer".

Aí os índios pegaram flecha e arco branco, os avós dos Yawalapití pegaram; e retiraram-se. O avô de Kutanaphu recusou a carabina, ficou só com arco e flecha. Veio Waurá: "Só quero flecha também: e pegou panela. Avô de Kamayurá veio: "Quero flecha também, arco preto e pena de tucano nas flechas, e de rei-congo"; recusaram também a carabina.

"Toma leite", disse Kwat. Recusaram.

Os avós de Kalapálo quiseram flecha e arco branco e cuia, e colar de cintura. Avô de lanahukwá pegou flecha, colar de pescoço, cuia, óleo de piqui e arco branco. Avô de Matipú apanhou colar de Matipú, arco branco e flecha e cuia e cipó de matar peixe, e feitiço ${ }^{8}$ levou tudo para casa. Avô de Kuikúro pegou flecha, colar de cintura, cuia grande, e foi guardar tudo. Avô de Trumaí ficou com arco branco e flecha de ubá, penas de tucano e rei-congo. O avô de Awetï tomou flecha, arco preto e branco, borduna, pena de tucano. Um bicho, parecido com mutuca, mordeu-o; levou esse bicho também, dentro de um saco, e guardou tudo na casa.

O avô de Cajabi pegou flecha de kamayïp (esse é nome Kamayurá; para os Awetï é tempẽ 'ãndu e pena de arara. Eram os primeiros índios bravos. Avô de Juruna pegou a mesma flecha, e borduna, e foi embora. Avô de Suyá pegou a mesma flecha e arco preto, borduna, unha de onça e pena de arara. O avô de Txukakamãe, apanhou dessas flechas. arco, borduna, arara vermelha. Avô de Mundurukú pegou a mesma flecha. E avô de Txikão, flecha de ubá, pena de tucano e arco branco.

Os avós dos índios recusaram o leite oferecido por Kwat, por ser sujo. Também não pegaram a carabina.

Kwat foi-se deitar. Ao meio dia levantou-se e foi fazer pedra, e gritava na pedra. Kwat fez de pedra o avô de Caraíba: de pedra branca [tabatinga], brancos, e de pedra preta, os pretos.

E a pedra gritava muito; era o avô de Caraíba. Mandou o avô de Caraíba pegar a carabina, machado, facão, camisa, máquina, gravador, leite, pinga, tudo. Então o avô de Caraíba foi embora. Beberam leite e pinga, rapadura, cana, açúcar e feijão.

Kwat levou o avô dos Caraíbas para muito longe. Aí o Caraíba veio e viu os índios no Rio. Discutiram se era bicho, ou gente. Aí brigaram. Os índios mataram o avô [os avós] dos Caraíbas. Foram matando, com flecha e borduna. Aí o avô dos Caraíbas veio e matou avô de índio, de todos eles.

\footnotetext{
${ }^{8}$ O feitiço (Kamayurá muãng) e o feiticeiro (K. muãngyatl) são socialmente desaprovados. Este difere do xamã (k. paye), que é benéfico.
} 
Aí os avós dos índios fugiram, pelo mato. E aí os avós dos índios vieram para cá e os Caraíbas ficaram no Rio9.

Os Kubencongre são tribo Txukahamãe, que também veio.

\section{ARQUE-MITO}

\section{0 - ORIGENS DO ANCESTRAL (v. ref. 221)}

Nos começos, só existiam Morcego e jatobá [111: Pau-preto]. Passeando pela noite, o Morcego viu a filha do Jatobá reclusa em sua casa; entrou e às escondidas possuiu-a, partindo de manhã cedo. Deixou-a grávida, e sua mãe, ao descobrir, exigiu-lhe zangada e sem êxito o nome do amante. Três luas passadas nasceu o Ancestral (Kwamuty) ${ }^{10}$, pai, avô dos índios e civilizados. 322a:

Então, era de noite, ainda.

O Ancestral cresceu, e o pai de sua mãe quis saber de quem era filho: ela nada revelou. Quando o menino já estava andando, reuniu toda a gente no terreiro, mas unânimemente negaram a paternidade.

O jatobá resolveu mandar pareat chamar outras tribos; para ver se a elas pertencia o pai de seu neto. Ninguém existia nessa altura, nem Sol, nem índios xinguanos, nem civilizados, só havia Morcego e Pau. Veio a tribo dos Piqui que gritaram ao chegar, sentando-se no terreiro e lutando depois. Sem rir, o Ancestral sentou-se ao lado do jatobá, enquanto a mãe, envergonhada, ficava em casa chorando. Acabada a luta, os Piqui preparam-se para partir, e o jatobá indagou sobre o pai do Ancestral. Ninguém sabia.

Depois mandou chamar os Morcegos. Quando o pareat chegou lá, um trouxe banquinhos e fê-lo sentar, todos estavam contentes por ter vindo pareat. O chefe dos Morcegos perguntou quem o chamava e porque, e o pareat explicou. Disputando entre si, todos se declararam pais do menino. (E este ouviu. Estava alegre, ia crescer e fazer gente). Depois o pareat partiu, na sua aldeia deu conta da missão, e o jatobá preparou bebida para os futuros visitantes. Assim, ficaram sabendo que o pai era o Morcego, mas a moça não disse nada. E o jatobá chorou de vergonha,

\footnotetext{
${ }^{9}$ Rio de Janeiro. Esta memória de fundo histórico é fruto do contato com civilizados.

${ }^{10}$ Mantendo a designação genérica, que torna mais fácil acompanhar a narrativa, quando necessário introduzirmos entre parênteses os nomel dos principais personagens conforme a língua da variante. Outros têrmos indigenas, salvo outra indicação, vêm na língua da variante de referência.
} 
todos conheciam a falta de sua filha e falavam mal dela e do Morcego. Só o Ancestral estava contente.

De manhã os Morcegos pintaram-se quando lhes trouxeram comida de festa, e a "mãe do avô" (sic) do Ancestral também o pintou e enfeitou. Depois os Morcegos vieram e o Jatobá esperou-os com o neto ao lado, sentado no terreiro onde recebeu os chefes dos Morcegos. A seguir os Morcegos e Jatobás lutaram, até que o Jatobá mandou parar e trouxeram comida aos visitantes. O Ancestral procurou a mãe que chorava envergonhada, mas ela permaneceu sem responder quando lhe disse que casasse com o Morcego. Por ter gerado o Ancestral em sua filha, o Morcego pagou ao Jatobá com armas e enfeites, e assim os Jatobá se tornaram cientes de tudo.

Já homem, o Ancestral foi passear no mato, e, copulando com um ninho de cupim durante muitos dias, engendrou duas filhas, que depois libertou com um machado, levando-as comigo. Elas cresceram e ficaram moças, cozinhando para ele.

\section{0 - AMPLIAÇÃO DA TERRA (v. ref. 128)}

(Antes a terra era pequena e de cor vermelha, e nela o Ancestral (Mavutsinĩ) fincou em circulo os primeiros Kwarïp. Mas sendo pequena e não dando para fazer muita gente, bateu repetidamente com o pé direito e ampliou-a, ficando grande para os índios e os brancos. Àquela terra vermelha o Ancestral enterrou-a e cobriu-a com terra escura, porque a vermelha não presta para nada. Escondeu a terra vermelha, e é lá no Murena que ela está.)

\section{0 - O ANCESTRAL FAZ GENTE DE TRONCOS (v. ref. 127)}

Foi assim que o Ancestral começou a fazer kwarïp. Cortou troncos de mavu e Kamiuwa, erguendo-os e pintando-os. Passada a noite os troncos começaram a virar gente toda paramentada, e o Ancestral avisou que quem houvesse tido relações sexuais permanecesse escondido e longe dos kwarïp, pois queria que se tornassem humanos. Quando os kwarïp mexeram, todos gritaram alegres, mas um homem que copulara saiu da casa, e os kwarïp voltaram a ser troncos. Antigamente, ao fazer-se kwarip os mortos retomavam e era isso que o Ancestral queria. Mas aquele que estivera com mulher apareceu e agora os kwarïp não mais se transformam. O kwarïp hoje é só para lembrar, e aqueles primeiros estão lá no Murena, onde os fizeram. 
O Ancestral fabricou os Kamayurá da madeira kwarïp, por isso são escuros, e os Kuikúro também. Os Yawalapití fê-los de mayakïp, por isso são meio escuros; e os Caraíbas de mavu (por isso são claros). Foi também então que o Ancestral começou o canto de pintar kwarïp.

No Murema, o Ancestral fez toda a gente bonita, e ele queria que ali morasse. Também aquele kwarïp que só se metamorfoseou da cintura para cima está oculto por lá. Se alguém morria, no kwarïp o morto voltava, e o Ancestral zangou-se ao ser interrompido.

211: Quando pela primeira vez transformou os troncos ao nascer do sol, vieram as onças e os peixes e lutaram entre si, com grande algazarra dos peixes e dos pássaros.

Porque o Ancestral começou, temos sempre de fazer kwarïp. Naquele tempo, Lua (Yai) ainda não existia.

121b, 122, 124, 126a: Depois o Ancestral fez o primeiro arco preto, seguido do arco branco, da borduna, das armas de fogo: a flecha e o arco preto eram para os Kamayurá, o arco de pindaíba para os Kuikúro, e a rede para os Waurá.

De manhã cedo o Ancestral levantou-se e foi apanhar fibra de tucum [111: pau preto de fazer arco. 221: fibra de tucum para fazer rede]. Essa corda de arco era da Onça, perto de cuja casa o Ancestral a encontrou. As onças cercaram-no ameaçando matá-lo, mas, chamando-lhes o chefe de "filho da irmã", o Ancestral pediu que não o matassem, pois em troca lhe daria mulheres. O adversário anuiu e deixou-o ir, mas ficou disputando a respeito com seus camaradas.

De regresso a casa, o Ancestral anunciou às filhas que casariam com a Onça, mas elas, com medo da mãe do futuro marido, recusaram. Diante disso o Ancestral foi de madrugada cortar certo número de paus [127:4 paus, 123:1,125:6, 126:3, 211:12, 221:3, 311:2, 322a:5], escondeu-os com folhas mágicas e de manhã fez-lhes braços, olhos com sementes, mas pés não porque era impossível. Experimentou por-lhes cabelo de embira de buriti com carvão, mas ficou mal, e o pelo do guará também, por ser branco [311: corda de buriti por ser branca]. Recorreu então à ajuda do passarinho Tsitsika, que possui o cabelo preto que temos, e disso foi feito o cabelo. [311: de barba de milho com algas de um lago próximo].

Os dentes, tentou fazer-lhes de pedra, mas o riso era preto e feio, como o era com dentes de concha, que além disso quebravam. Pediu por isso auxílio a Kakatsi, e fizeram os dentes, pequenos e branquinhos, das sementes de mangaba. Por serem de sementes é que eles se estragam facilmente. 
Logo, o Ancestral preparou cintos de embira de buriti, iguais aos das meninas, e chamou a Embira, para com ela fazer a cobertura pubiana. Mas a Embira recusou, só queria servir para amarração. Em vista disso o Ancestral chamou o Tamehawp, que foi, mas de olhos fechados por não gostar do cheiro de vaginal. (Naquele tempo, os bichos e plantas eram como gente). 311: Pronto o cinto, o Ancestral deixou de lhe colocar o cordão perineal.

No dia seguinte o Ancestral pintou as moças com urukuyup e tïwïtïwi $i$. 311: Fez bancos de pau para si e para elas, indo dormir, e no outro dia encontrou-as sentadas nos bancos; mas faltavam-lhes ainda os orifícios do corpo, que ele completou, iguais aos nossos. 221: A vagina, moldou-a com cera.

Deu-lhes depois pente e urucu, e mandou-as para casa da Onça. Foram e uma esqueceu o pente; voltando para buscá-lo, perdeu-se e gritou, sem que as outras respondessem, e uma destas disse que ficasse assim daí por diante, gritando pelos matos como bicho. É hoje o mama'ẽ Yawïrïunyã, cujos cabelos são longos e vive gritando na floresta. [311: encontraram um lago amargo, e uma das moças, teimando em beber, afogou-se.]

Prosseguiram e encontraram a Anta, a quem perguntaram pelo caminho; mostrando-o, ela exigiu ter relações sexuais com uma, mas o seu órgão desmesurado matou a mulher. 311: Esta partiu-se ao meio e a Anta fugiu, ao ver que era de pau. [221: As mulheres recusaram-se por acharem a Anta feia.)

O Ancestral mandou que a planta Yeke' a deflorasse outra moça, pois seus frutos eram como penis de todos os tamanhos. [221: o Viado queria casar com ela, recusaram-no por causa das pernas finas. 311: Martim-Pescador ensinou o caminho e deu-lhes três peixes, deitando-se com uma.]

Deram depois com o Tatu, que lhes indicou por onde seguir e quis possuir uma delas; mas como estava sem penis, aproveitaram para fugir enquanto o ia buscar. [221: Vieram e foram recusados por causa de suas características: o Queixada, sujo e feio; o Caititu, feio demais; o Tamanduá, chato e de rabo e nariz comprido; a Capivara, de dentes grande e nariz redondo; todo o pessoal da Onça foi lá sem resultado. 311: Irara ensinoulhes a direção, deu mel-de-pau e obrigou uma das moças a entregar-se.] 311: Irritadas e reclamando contra as contínuas exigências de relações, elas continuaram e resolveram fazer o cordão perineal do uluri. Para obter a fibra necessária, uma subiu a um buriti e derrubou-lhe o broto, que caiu com a ponta para cima. Outra, das de baixo, colheu uma folha e fez uma mutuca, que voou e foi picar a do alto; ela caiu, e o broto do buriti entrou- 
lhe pela vagina, matando-a. As duas mulheres que sobraram, seguiram adiante deixando-a insepulta.

Pelas 15:00 horas chegaram a um lago, e, trepando numa árvore, aguardaram, perto de seu porto, a flecha de assobio da Onça. As onças estavam jogando bola.

A anu preto fêmea, Nyainyakunyã [221: uma mulher. 311: a Seriema] veio banhar-se com seu marido, comentando não ser preta, ser branca. As moças, escondidas, fizeram mutuca e mandaram-na morde-la [125: riram do disparate.311: a mutuca mordeu uma das moças, que lhe bateu, fazendo-a ir picar a Seriema]. O anu olhou para cima, viu as moças e perguntoulhes o que faziam. [125: os anus correram assustados. 311: A Seriema quebrou o pote e molhou-se, sendo em casa repreendida pelo marido]. Responderam que esperavam o pessoal, e o anu foi avisar a Onça de que a esperavam no porto.

A Onça foi ver, atirando flechas de assobio. Duvidando de que se tratasse da Onça, as moças não apanharam a flecha. Desapontada e estranhando, pois Mavutsinĩ prometera, foi-se embora com sua flecha, achando que não era consigo e que eles não seriam seus parentes. [221: a Onça foi lá e as moças. achando-a feia, não a acompanharam].

Depois, o Amigo ou Irmão da Onça (Awaratsiinng) jogou sua flecha de assobio, e as mulheres apanharam-na [221: veio a espécie de onça Wau, que acompanharam por ser bonita]. Awaratsing era vermelho e tinha o trazeiro cheio de feridas, o que lhes revelou sua identidade. [311: após o encontro com a Siriema, as moças continuaram até uma encruzilhada, onde se separaram; uma foi ter à casa do Lobo, e a outra à da Onça (Nitzuengle), que lhe perguntou pela que faltava]. A Onça ficou zangada por terem ido para casa de seu Amigo, onde só se comia fruta de minata. A mãe da Onça usava polvilho, não minata, e o que as moças queriam era comida de mandioca, não de fruta. No dia seguinte a Mãe do Amigo da Onça mandou-as buscar a comida que queriam à casa da Onça, e sua Mãe recriminou-as por não terem casado com o filho. Nesse tempo, as onças eram como gente e só comiam caça [221: comiam "peixe que era na verdade a gente do Ancestral (Kwamuty). 322: A Onça (Oka) só comia Bakairí1, e foram pedir a seu chefe para caçar. Ele autorizou que partissem no dia seguinte. Bem cedo as moças levantaram-se e prepararam beiju para os caçadores, que a Onça pegou e distribuiu entre eles. No caminho para a caçada, a Onça fingiu ter os olhos doentes e regressou, deixando os outros continuarem. Para tomar as mulheres do Amigo, voltou jogando flecha de assobio [221: dardos de Yawari de assobio. 311: Onça (Nitzuengle) foi buscar a mulher a casa do Lobo com seus homens armados, e jogando 
dessas flechas), e quando chegou ao meio do terreiro, as mulheres apanharam-lhe a flecha. A Onça levou-as para casa.

Quando os caçadores voltaram assaram e mandaram pedaços de carne para elas. O Amigo mandou chamá-las, e ela enviaram-lhe beiju, dizendo que esperasse. [221: A Onça (Tsumare) fez assar o "peixe" = gente, mas as moças recusaram comer. Chorando à sombra da casa, elas com um pauzinho desenharam-se os risquinhos que temos na palma das mãos, e declararam que, casada com elas, a Onça tinha de proibir a matança de sua gente. Ameaçaram partir se não recebessem peixe. Triste, a Onça discursou no terreiro contando o que se passava, ordenando pescar, e advertindo que não podiam mais matar o pessoal do sogro. De manhã cedo fizeram pescaria, e as mulheres alegraram-se por só ter vindo verdadeiro peixe. A Onça pôs bebida e peixe e nunca mais comeram gente].

O Amigo mandou insistir em que voltassem, mas elas não quiseram: lá só havia minata. Quando a Mãe do Amigo voltou para chamá-las, deram-lhe mingau de piqui, cheio de espinhos. Ela engasgou-se e fugiu para o mato roncando. Quando o Amigo apareceu fizeram-lhe o mesmo, e ele ficou como a Mãe e como é hoje. E elas, continuaram morando com a Onça.

Estando uma das mulheres já grávida da Onça [121a: de Mavutsini. 322: de dois ossos de Bakairí que engolira. 411a: não se sabe se foi a Onça que a engravidou], o marido recomendou-lhes que não catassem piolho de sua Mãe, pois se o fizessem esta as comeria. Um dia, foi à roça com uma das mulheres, deixando a que estava prenhe em casa. A Mãe da Onça pediu à nora que a catasse, e, quando a moça comeu o piolho, entrou-lhe na bôca um cabelo que tentou cuspir. Zangada e acusando-a de ter nojo e não gostar dela, a sogra agarrou-a pelo pescoço e matou-a. [221: a sogra ao varrer emitiu gazes, a moça cuspiu, e a outra em represália matou-a. 311: idem. 322: a sogra, não querendo que a nora gerasse filhos de Bakairí, matou-a arrancando-lhe os olhos]. Depois, a Mãe da Onça fugiu e escondeu-se [311: com a ajuda do filho].

Ao voltarem deram com o acontecido. A irmã da morta logo disse desconfiar da sogra, e a Onça foi procurá-la. 322: a Onça (Oka) quis matar a homicida, mas poupou-a porque ela lhe lembrou ser sua Mãe.

Como a defunta esperava criança, chamaram um avô, a formiga Tanahã, para que fizesse o parto, e, para ajudar, o passarinho Kuykuy, o sapo Takutaku e o Morcego Aru'a. A formiga entrou pela vagina da mulher, viu que eram dois os meninos e extraiu-os, um de cada vez. [111: o Ancestral (Mavutsinĩ) tirou os meninos do seio materno. 12la: o Ancestral (Mavutsinĩ) copulou e engravidou a mulher, nascendo um menino; depois 
repetiu o feito. 221: a formiga viu os meninos e a Onça (Tsumare) praticou a cesariana, cortando o rabo que as crianças tinham. 322: a cesárea foi feita por Kuara, jaguar irmão da Onça (Oka)]. Depois de nascidos, os Gêmeos (foram guardados numa cabaça como a de criar periquitos e papagaios [111: numa mala. 123: numa caixa. 125, 126: num recinto de reclusão, mïritsi. 221, 224: numa panela de barro, tapada], que a seguir foi pendurada no alto da casa.

125: A Onça pediu a seu avô Tumutumuri, o marimbondo riscado e de cabeça vermelha para fazer o enterro. 127: Ele veio, e Tanahã ajudou-o a sepultar a defunta, em sua rede e de pé, por ser grande "capitão" a mulher feita pelo Ancestral. A cova foi bem no meio do terreiro. Costuraram-lhe a rede formando o motivo decorativo tapaka, e Tumutumuri mandou carregar a morta em redor da casa, numa procissão semelhante à do Kwarïp. Cantaram, e depois cobriram o buraco com terra [311: a Onça (Nitzuengle) atirou com a mulher para a cobertura da casa, por não saber sepultá-la. 322: Kuara e os outros assaram-na e comeram-na, dando bocados à Onça (Oka), que, ao regressar da procura da Mãe, comeu sem suspeitar].

126: De manhã os meninos já estavam mexendo. 221: Dez dias depois já andavam dentro da panela e, estando a casa vazia, saíram e foram comer. 127: No regresso a casa, a Onça e a mulher restante viram o rasto dos meninos. [221: o pessoal viu o rasto dos meninos].

A Mãe de Criação [126: a, Onça (Yawat)] pôs à porta dos meninos "uluri" e a rodilha de carregar, mas os meninos não pegaram; trouxe então urukuyup e cabacinha, e eles tampouco ligaram. [123, 125, 126: O pai] trouxe-lhe 2 arco e 2 flechas, que os meninos recolheram. Assim ficaram sabendo que eles eram homens, porque até então nem a Onça nem a Mãe de Criação os tinham visto. 126: Mais tarde, eles andaram dentro do mïrïsi, e saíram para caçar passarinho e calangos, fora de casa.

Querendo surpreende-los, a Onça e sua mulher esconderam-se e esperaram [221: puseram terra no chão para apanhar-lhes o rastro. 224: Ouvindo barulho de noite a Onça (Tsumare) alumiou e foi vê-los]. A Onça e a madrasta deles entraram, quando os meninos estavam no chão, e disseram-lhes que não precisavam ocultar-se de seus pais [111: Sol chorava na mala e o Ancestral (Mamutsinĩ) soltou-o. 221, 224: a Onça (Tsumare) abriu a panela e viu os meninos; o Sol pediu à irmã da mãe que o criasse.] 111: a Mãe de Criação, para os consolar, deu-lhes beiju de pau e mingau de tabatinga [221: fez-lhes beiju]. 111, 125, 126: Os meninos foram caçar passarinhos e calangos.

A Onça [126: a madrasta] recomendou-lhes não brigar com ninguém, e que não mexessem com o calango Teyuparap, que era avô deles. Saíram, 
mataram-no, tinha cinco dedos. Por ser avô, enterraram-no. A Onça disselhes que não matassem a paca, por ser também um avô. Quando a paca estava a aquecer-se ao sol diante de casa, mataram-na para ver se era verdade. Não era, só tinha três dedos. Nessa altura não se comia carne, eles é que começaram; esfolaram, e assaram a paca, e a Onça pediu um pedaço. (A Onça era pai do Sol e da Lua (Kwat e Yaì), mas não sabia coisa nenhuma. O Ancestral fez de pau a Mãe deles: eles fizeram o resto). A Onça proibiu-lhes também matar cotia, mas eles mataram-na e viram que não era avô, porque não tinha cinco dedos. Esfolaram e moquearam a cotia, o pai deles gostou do cheiro e pediu; a Mãe de Criação, também comeu. Os Gêmeos acharam bem e determinaram que no futuro, só carne seria o alimento da Onça. A gente não comia caça naquela época, só macaco. Mataram o lagarto Kuviara, tinha cinco dedos e era, portanto, avó. Disseram-lhes depois para não matar o veado, mas fizeram-no quando capinava sua roça. Não era avó, tinha dois dedos. Esfolaram-no e moquearam, a Onça pediu: e os meninos insistiram, dizendo que a Onça só comeria carne.

Encontraram o Tatu, que lhes perguntou o nome: disseram não ter, serem chamados "sem nome" pela Mãe (madrasta). O Tatu então batizou o Sol de tape iyau e a Lua de Tape akanã, e de volta a casa, a Mãe de Criação perguntou-lhes quem lhes dera aqueles nomes. "O Tatu" - disseram. E por causa disso respeitaram-no, não o mataram.

Apesar da recomendação em contrário da Mãe de Criação, foram roubar amendoim à roça da perdiz Kuyatïtï, avó também [221: perdigão = inhambu grande]. Quando essa mulher descobriu, ficou irritada e perguntou-se quem seria o ladrão, comentando que com certeza os meninos órfãos. Perguntaram-lhe e Kuyatïtï contou [221: amolaram-lhe o rabo com uma pedra para que contasse. 311: Sol bateu-lhe por detrás para a fazer contar] onde estava o corpo da Mãe deles, e onde a Avó, Mãe da Onça, se escondia, no mato atrás da casa [126: em meio ao abacaxi do mato. 311: longe, numa casa à beira d'água]; disse ainda que a que consideravam Mãe, não o era realmente. [322a: a Tia-Avó Ewakí contou que a Avó lhes matara a Mãe].

A seguir passaram terra vermelha nas costas da Kuyatïti, que se tornou num pássaro que voou, dizendo: "Sem mãe!" [311: Da surra, ela ficou feia e medrosa como é.] 127: Os meninos disseram que sabiam não ter mãe, e mandaram-na cantar direito.

Chorando, os meninos regressaram. A Mãe de Criação tentou consolálos, mas soube que choravam pela Mãe de verdade; queixaram-se que ela não o era, sendo só aikama (irmã da mãe = mãe de criação). [111: Chorando, Sol pediu comida, reclamando que aquela não passava de terra e pau 
podre; entrou num porco feito com cabelo seu, e foi com outros bichos roubar a roça do Ancestral, que de manhã os enxotou, indo deitar-se zangado. Como o Sol chorava, o avô deu-lhe beiju. O neto dormiu e depois foi brincar nágua, enquanto isso a Onça veio e pos-lhe um socó e um gambá em casa].

Após perguntarem pelo esconderijo da Avó (Mãe da Onça), os meninos diminuíram de tamanho e partiram em sua busca. 128, 125, 126: Quem mostrou o local onde ela estava foi o calango [221: a Onça disse-lhes onde era], em meio ao abacaxi do mato. [311: a Casa da Avó estava velha, suja e cheia de bichos; o Acauá ajudou-os a dar cabo das cobras, a Anta a liquidar as pulgas, o Bilro a exterminar os marimbondos].

A Avó recebeu-os bem e brincou com eles chamando-os Tirè ïm ("sem mãe"), mas os Gêmeos tinham uma pedra oculta sob o pé, para matá-la. 311: Citando a perdiz, acusaram a Avó do desaparecimento da Mãe, mas ela fingiu-se ignorante, atribuindo-o, talvez, a febres: mas de nada poderia saber, pois há muito que morava no mato... 127: Então pularam sobre o coração da velha, e o peso da pedra acabou com ela.

311: O Sol mandou o irmão apanhar fogo com a Mãe de Criação, pretextando quererem queimar marimbondos. Incendiaram a casa e a velha [322a: a velha], cujos ossos saltavam longe ao arder. Observavam, bem abrigados, quando a Lua se expôs e foi tingida por um pau que lhe arrancou o nariz [322a.: a Lua incendiou-se], e morreu, por isso a vemos no céu sem nariz. 322a: o Sol soprou sobre a Lua e ressuscitou-a, fazendo-lhe nariz e mãos como de homem. Antes eram como de papagaio. Logo após o mesmo acidente e ressurreição aconteceram ao Sol. Vieram então a lontra pequena, a ariranha, e o tucano, que respectivamente levaram consigo as caudas, as mãos, os pés, e os bicos, dos quais o maior era o do Sol].

126: Neste tempo, os meninos ainda não tinham nome (i.e., nome definitivo). 127: Regressaram a casa, comentando a vingança tomada, e, à pergunta da Mãe de Criação responderam não haver molestado a Avó [126: a Onça concordou com a desforra]. Perguntaram pela Mãe e pelo Pai, e a madrasta mostrou-lhes a sepultura da primeira. [322a: com vergonha, a Onça (Oka) nunca revelou aos Gêmeos o acontecido]. 126: Perto do enterratório, choraram ritualmente, primeiro como os xinguanos, depois como as tribos marginais à área. Choraram pela Mãe e ela respondeu-lhes baixinho; eles cavaram e falaram com ela. Mas ela já estava morta. [125: apesar de morta há muito ainda estava viva. 126: não podia falar porque os vermes the tinham devorado a garganta]. Se tivessem acudido antes, tê-laiam salvo. 221: A Mãe de Criação veio então, e disse-lhes que a deviam deixar. 
[311: o Sol tirou a Mãe da cobertura da casa onde a pusera a Onça, colocou-lhe remédio e ela respondeu. Alegre deitou-se a seu lado, mas no açodamento bateu-lhe e matou-a].

Chamaram o marimbondo riscado Tumutumuri para que lhes enterrasse a Mãe. O pai há muito não se pintava, mas os Gêmeos mandaram-no pescar, para haver pintura e se acabar a saudade. A Onça assim fez convocando a todos para a pesca e exortando-os a não sair da aldeia. Cantaram para que a alma da morta partisse, e trouxeram mingau para o terreiro, a fim de realizar a cerimônia do banho ritual. Depois banharam o Tumutumuri e pintaram-no de vermelho, na cabeça. E mataram paca e cotia para comer.

(322a: a Onça ( Oka) era a pintada, que flechava e comia os Bakairí. Sua Mãe parecia jaó e macuco, e tinha unhas como polegares: comeu tantos Bakairí que o Sol teve de fazer mais. Por causa daquilo é que a Onça não come jaó e macuco. O Ancestral (Kamuschini) é como as aranhas pretas e com pouco pelo que sobem ao céu em agosto e setembro.)

Mais tarde os meninos foram pedir taquarinhas ao gambá Tsawarape, que as deu [111, 221, 224, 311, 322: pediram flechas à Onça. 123, 222: os meninos fizeram muitas flechas]. 221: Fingindo ir caçar, foram pedindo flechas em dias sucessivos. 111: primeiro pegaram flechas de ubá, depois de cambaiuva, que são avós dos xinguanos e dos índios bravos. [322: as flechas eram infantis, de talos de buriti].

Cortaram aquelas taquarinhas em pedaços de uns $10 \mathrm{~cm}$., e, fincandoos verticalmente, rodearam com eles a casa. 221, 222: No mato, os Gêmeos pintaram-se como para Yawari (uma festa), e, no meio do circulo, gritaram e fumaram sobre as armas. 127: Elas transformaram-se em Txukakamãe e Kayabí, Suyá não porque são pedacinho de cobra. [221, 222: viraram Waurá, Mehinaku, Matipu, Trumaí; Kayabí, Xerente, Xavante, Txikão; Civilizado. 321: apareceram os Bakairí e Kayabí. 322a: vieram, magicamente, os Kayabi. 411b: o Sol fez toda a gente de flechas].

[311: o Sol deu cinza de taquarinha para a tia comer, durante muito tempo, e ela ficou grávida dos índios bravos, que, às escondidas da Onça, nasceram no mato. O Sol mostrou ao pai os filhotes do Gambá, fazendo-os passar por filhos da Mãe de Criação. Depois, armou os índios bravos com as armas que lhe dera a Onça.]

[111: À noite, o Sol fez carabina, avô dos caraíbas].

126: A Onça tentou moldar o corpo dos filhos como o seu próprio, mas não suportaram a dor, e gritaram por socorro. 127: Os índios bravos vieram e atacaram o pessoal da Onça; os meninos pegaram-na dentro de casa, e atiraram-na para o céu em companhia de sua mulher. Depois fize- 
ram massa de cinza para que o pai fosse para o céu [221: o Sol encheu uma cabaça com cinza e raspas de casca de arco, e arremessou-a para o alto, transformando-a num gavião - no qual posteriormente ascendeu ao céu; a Onça fugiu para o mato. 111: por meio de uma pindaíba encurvada, o Sol atirou a Onça, a anta e o veado para o céu. 311: o Sol, valendo-se ele seu arco, disparou o pai para o céu, mandando também o socó para pescar para ele. 322a: os índios bravos flecharam e erraram a Onça; o Sol conseguiu ferí-la no joelho, mas assim mesmo escapou para o mato].

126: Agora o pai e a madrasta dos Gêmeos chamam-se Iwakakape ayrupi, (" os que estão no caminho do céu, i.é., na Via Láctea!). 111: As flechas-índio mataram as onças todas, mas a carabina não participou da luta. 127: Só restaram o Sol e a Lua, que deram aldeias àqueles índios todos. 311: O Sol distribuiu-os pelo Kulisehu-Kuluene até Murena, e assim surgiram os índios bravos que atacam os bons.

A Lua perguntou ao Sol aonde iriam, agora, e ele respondeu que aguardariam o Ancestral, que logo apareceu e lhes perguntou pelos seus. Contaram-lhe tudo e o Avô levou-os para Murena [322a: os Gêmeos ficaram no Salto pois aí morava seu avô Tumehi/Tumeng, marido de sua tiaavó Ewaki]. 126: No Murena iam fazer muitas coisas. 123: E muita gente também. 223: o Sol fez no Murena as tribos xinguanas, e toda a gente. 123: De lá mandou essa gente para outros lugares, e deu-lhes fogo para levar.

126: No Murena perguntaram-lhes o nome; responderam: "Tsaukuma". Mas Kwarayumiá, espécie de grilo, disse-lhes que esse não prestava e que lhes daria o seu. Nominou-os Kwat (Sol), o mais velho, e Yaï(Lua), o mais novo. Os meninos, contentes, aceitaram. [311: Ao caçar encontraram o gafanhoto Tucura, que ficou sabendo que não tinham nome. Deu-lhes então o seu próprio. Rititaurinhe. O Sol cresceu e ficou grande e forte como a Anta. (Mais tarde tentou subir ao céu no veado, que correu de um lado para outro, sem conseguir: subiu então nas asas do gavião uirassu). [322b: Os Gêmeos pediram a Tumeng que lhes fizesse casa; e Tumeng soprou sobre o cupim e fez pedras. Depois ensinou-os a pescar, a fazer moquém e outras coisas. Os Gêmeos agora já eram adultos, e já tinham os elementos necessários: sol, lua, rede, sono, rio, salto, peixe, casa, moquém.

4.0 - BAKAIRÍ: FESTAS ALUA E IMEO. MULTIPLICAÇÃO E DISPERSÃO DAS TRIBOS (v. ref. 322b)

Os Bakairí moravam com o Sol (Keri) a E do Salto do Paranatinga, onde ele havia feito um morro do qual se via ao longe. A Lua (Kame) fez 
uma casa de festas e uma flauta, e convidou o irmão e sua gente. Dançaram, e o organizador da festa deu muito mingau e beiju aos convidados, recebendo em troca presentes de flechas e fio de algodão.

Tempo depois, o Sol retribuiu a festa no Salto, e nessa ocasião dançaram o makanari (do Morcego grande e do Morcego pequeno) e o imigo (da lagarta das palmeiras). Dançaram dois dias e duas noites, descansando de noite e banhando-se de manhã, nessa festa de que era dono o Sol. Como este fizera muitos Bakairí de cana de ubá e seu irmão não fizera nenhum, repreendeu a preguiça do outro e desentenderam-se. Mais fraco, a Lua fugiu para SW e elevou outro morro no Rio Beijaflor, e ali fez os Apiaká, os Paresí e os Guaná.

O Sol, de seu morro no Salto, viu a fumaça da aldeia da Lua e foi lá, irritando-se com a quantidade de gente que o irmão fizera. Brigaram de novo, mas a Lua acabou deixando-os a todos e regressando em companhia do irmão. Mas o Sol também já fizera muitos homens e surgiu novo conflito; desta vez, a Lua foi para o R. Arinos, mas o outro foi atrás e fê-lo voltar.

Nestas idas e vindas, o Sol fez a oriente os Bakairí, Kayabí, Bororo, Nahukawá, Mehináku; e a Lua, a ocidente, os Apiaká, Paresí, Guaná, Maué, Suyá, Mundurukú, enfim, "todas as tribos do Arinos". Haste de flecha foi o material usado para os índios, mas para os portuguêses foi uma cana escura, da cor da coronha de espingarda.

Primeiro o Sol deu a espingarda ao Bakairí, mas como não a soube usar, deu-a depois ao Caraíba. [321: O Imperador = Sol passeava com 1 Bakairí e 1 Branco ao longo do Paranatinga. O Branco ia pelo Xingu, e um dia deixou de responder quando o Sol lhe falava, por ter sido engolido pelo peixe jaú. Um pato mandado pelo Sol fez com que o peixe vomitasse o Branco, que continuou até ao mar e embarcou. Passado tempo, voltou com a espingarda].

\section{1 - AWETİ: ATRIBUIÇÃO DOS ELEMENTOS CULTURAIS DISTIN- TIVOS ÀS TRIBOS (v. ref. 111)}

Quando os índios gerados de flechas vieram, trouxeram-lhes mingau, leite, pinga, mas eles recusaram a pinga por ser suja. O Sol perguntou-lhes o que queriam então, e o Yawalapití decidiu-se pelo arco e flecha. O Kustenáu, desprezando a carabina, tomou também arco e flecha; o Waurá, flecha e panela. O Kamayurá não pegou nem a carabina nem o leite, preferiu a flecha com pena de tucano, o arco preto, e penas de rei-congo. O Kalapálo ficou com flecha, colar de pescoço, cuia, óleo de piqui, arco 
branco; Matipú com colar, arco branco, flecha, cuia, timbó, feitiço; e o Kuikúro com flecha, colar de cintura e cuia grande. O Trumaí apanhou o arco branco e flecha de ubá, pena de tucano e rei-congo. E o Awetï pegou flecha, arco preto, arco branco, borduna, pena de tucano e um bicho parecido com mutuca.

Depois os índios bravos Kayabí tomaram paar si flecha de cambaiúva, e pena de arara; o Yurúna, flecha de cambaiúva e borduna; e o Suyá flecha de cambaiúva, arco preto, borduna, unha de onça, pena de arara. O Txukahamãe quis flecha de cambiúva, arco, borduna, arara vermelha, e o Mundurukú flecha de cambaiúva; por fim o Txikão teve a flecha de ubá, pena de tucano e arco branco.

Todos os avós dos índios recusaram a carabina, e o leite, que é sujo.

A seguir o Sol fez de "pedra" branca (tabatinga) o avô do Caraíba branco, e de pedra preta o do Caraíba preto, "e gritava muito na pedra". O Sol mandou o avô do Caraíba recolher a carabina, o machado, facão, camisa, máquina, gravador, leite, pinga. E ele comeu e bebeu leite, pinga, rapadura, cana, açúcar, feijão. Depois o Sol levou-o para muito longe.

Então o caraíba veio e no Rio de Janeiro viu os índios, duvidando se seriam gente. Entraram em choque e os índios acabaram refugiados no Xingu, ficando no Rio os recém-vindos. Para o Xingu também os Txukahamãe foram.

\section{2 - KAMAYURÁ: ATRIBUIÇÃO DOS ELEMENTOS CULTURAIS DISTINTIVOS ÀS TRIBOS (v. ref. 124)}

O Ancestral (Mavutsinĩ) reuniu arcos, borduna, flechas, armas de logo (rifles 44, 22, caçadeira) e mandou o Kamayurá pegar o rifle, o Kuikúro o arco branco, o Txukahamãe a borduna e o Waurá a panela. Mas o Kamayurá preferiu o arco preto ao rifle, porque este estava velho [122: quando chegou a vez do Kamayurá escolher só havia arco preto], e isto fez o Ancestral entristecer-se e zangar-se. 122: Vieram os outros índios [121b: os índios bravos], que ficaram com o arco branco. 124: e ao caraíbas foi dado [121b, ]22: escolheram] o rifle.

Irritado, o Ancestral despediu o Caraíba para longe [121b: espalhou os Brancos por toda a parte], e a seguir nasceu muita gente. 123: Isso foi lá em Murema. 124: Perto dele o Ancestral determinou que ficassem os Kuikúro, Wautá, Kamayurá [121a: mandou os 4 antepassados Kamayurá, Karanavarí, Kanaratí, Yanamá e Vanüvanï fazer aldeias no Ronuro, em Urukulu no Murena e em Vanïvanï respectivamente, ordenando-lhes que seguissem a rotina de banhar-se de manhã, assobiando, ter relações sexu- 
ais à noite e trabalhar de dia]. Os Txukahamãe foram embora porque são índios bravos [122, 123: distribuiu o resto dos índios por outros lugares, 123: dando-lhes fogo para levar]. 121b: Os brancos são mais fortes por terem armas de fogo, mas o Ancestral gosta mais dos Kamayurá e por isso os mandou ficar no Murena.

É por estas razões que os Kamayurá usam arco, os Caraíbas revólver e rifle, e os Waurá panela.

\section{3 - WAURÁ: ATRIBUIÇÃO DOS ELEMENTOS CULTURAIS DIS-} TINTIVOS ÀS TRIBOS (v. ref. 223)

O Sol foi quem fez os chefes dos índios, e como era o chefe deles mandou pôr um banquinho no meio do terreiro. 221: Reuniu ai os Waurá, Kuikúro, Nahukwá, etc.

222: A Onça mandou o filho aquecer água, e a Lua trouxe-a ${ }^{11}$. Depois disse ao Sol que aproximasse o avô dos Waurá, mas a Lua observou, que aquele ainda não tinha nome. Que se chamaria Waurá, foi o que disse a Onça. E o Sol foi buscar o avô dos Waurá. Ofereceram-lhe água quente num copo de alumínio, mas ele furtou-se a beber, e guardaram o copo. A Lua guardou também a carabina, que ele não soube manejar. A Onça fez então o Sol dar-lhe arco e flecha, pois mostrou-se capaz de empregá-los: e a Onça determinou que, assim, só usaria flechas. 223: Levando pelo pulso o chefe Waurá, o Sol conduziu-o à gente que seria a sua, dizendo-lhe que seria o chefe dela. E ali ficou ele, perto de sua tribo.

222: Chamaram o chefe Kamayurá, e ele não soube atirar com carabina; deram-lhe água quente e ele teve medo de beber. Foi por isso que lhe ofereceram o arco, que soube como utilizar. 223: Fizeram-no sentar-se no terreiro, e a tribo foi para junto de seu banquinho. O Sol declarou-lhes que aquele seria o chefe deles.

O mesmo se deu com os Yawalapití, Kuikúro, Kalapálo, Nahukwá. Todos os índios tiveram um chefe, mas sobrou um e o Sol foi dar parte disso ao Ancestral (Kwamuty), dizendo que esse chefe iria morar sózinho no mato.

De manhã o Sol enviou o avô dos Waurá para morar no Tsarivapi, e o dos Trumaí para Nariá, cêrca do Murena. O dos Yawalapití foi para

\footnotetext{
${ }^{11}$ Enquanto seu pessoal é atacado, a tradição Waurá omite-se a respeito da sorte final da Onça. Na v. 222 a Onça desempenha o mesmo papel que o Ancestral na v. 223. Dado o prévio conflito entre os Gêmeos e seu pai. a lição da V. 223 é mais coerente, e concorda com o resto da tradição xinguana.
} 
perto do Pôsto Leonardo, e a Lua determinou que o avô dos Kamayurá morasse perto do Lago (de Ipavu), e os dos Awetï e Mehinaku Kuluene acima: e disse ao dos Kuikúro que firasse no Kuluene. No Murena só restaram o Sol, a Lua, e Ancestral e o Civilizado.

222: O Sol deu a carabina ao Civilizado, porque sabia atirar, e também água quente para beber. 221: Deu-lhe como alimento o veado e a anta. 222: E a Onça declarou que, sabendo disparar a carabina, passava a chamar-se Civilizado. 223: O Sol perguntou também onde iria morar, e o Ancestral respondeu que bem longe; e o Civilizado foi.

Num lugar limpinho e sem árvores no Murená, ficou, só, o chefe de pedra. Ali existe também um lago pequeno e venenoso, e quem beber dele ou se aproximar do chefe, morre. Esse chefe era como gente, até que o Sol soprou sobre ele, transformando-o em pedra. Parece um boneco, o chefe perigoso que mata: a uns trinta metros a morte é certa, o chão está todo juncado dos ossos dos bichos que se chegaram.

Só os Trumaí e os Kamayurá sabem de seu paradeiro, e os últimos tentaram alcançá-lo, mas pereceram. Os Trumaí experimentaram também, e o mesmo ocorreu ao aproximarem-se de seu arco. Os Kamayurá criaram um menino com remédios mágicos especiais, para que pudesse apanhar o arco do chefe petrificado. Quando ficou adulto, o pai mandou-o provar, mas quando estava já quase tocando a mão do chefe, morreu.

O Kamayurá Uahu viu-o de longe, há pouco tempo, mas saiu vivo da experiência.

\section{4 - KALAPÁLO (?): ATRIBUIÇÃO DOS ELEMENTOS CULTURAIS DISTINTIVOS ÀS TRIBOS (v. ref. 312)}

O Ancestral (Mavutsini - sic) reuniu em Murena os chefes e um caraíba, juntou flechas, bordunas, Winchester 44, e mandou-os escolher. O Kamayurá ficou com o arco preto de secção circular, o Yuruna com o arco prêro de secção quadrangular, e o Suyá com a borduna [311: o Sol deu aos Txukahamãe flechas de "flecha" (uba), de taquari aos Suyá, e borduna aos Kayapo]. Aos Kalapálo coube a flecha de taquari e o arco vermelho, e aos Kuikúro também, assim como aos Trumaí e Yawalapití. O Branco ficou com a .44, e, por medo que matasse os índios, o Ancestral mandou-o para o mar. Os Suyá foram para o mato, e os outros índios para os respectivos lugares. 
4.5 - TRUMAÍ: ATRIBUIÇÃO DOS ELEMENTOS CULTURAIS DISTINTIVOS ÀS TRIBOS (v. ref. 411c)

O Sol (Atehle) distribuiu as terras do Kulisehu e do Kuluene pelas tribos, e colocou no chão o arco, panelas, cera, machado de ferro; depois mandou os Trumaí, Waurá, Kamayurá e Brancos escolher. Os Trumaí optaram pela cera, os Waurá pela panela, os Kamayurá pelo arco e os Brancos pelo machado de ferro. O Sol ficou zangado com a escolha dos Trumaí. $\mathrm{E}$ os Brancos, residentes rio abaixo ou nas nascentes do Kuluene, tem sua civilização graças ao machado de ferro.

\section{0 - KWARÏP DA MIFE DO SOL E DA LUA (v. ref. 127)}

Os Gêmeos decidiram fazer Kwarip de sua Mãe. (Um dos cantadores seria a Anta, outro, o Sapo).

125: O Ancestral ensinou-os, explicando que aquele kwarïp não se transformaria, que era só para recordarem, e que todos os anos deveriam realizar essa festa, atirando depois os troncos à água.

Mandaram [125: o Ancestral. 225: o Sol] como pareat o Pirabuku [225: a Piranha Vermelha], para convidar os peixes. 225: o pareat foi para a aldeia dos peixes, e ao chegar diante da casa do chefe dela, o PeixeCachorra, parou. Trouxeram-lhe banco, conduziram-no e sentaram-no nele. Veio o peixe-Cachorra e falou com o pareat, e depois os outros chefes falaram também. No dia seguinte, o pareat estava de volta a sua aldeia.

225: Mais tarde, os homens e mulheres da tribo dos peixes partiram, elas para assistir, eles para lutar. Os homens iam armados com yawari, e na ordem de marcha as mulheres ficavam à frente com os chefes, e os homens atrás. [125: 2 das tribos convidadas recusaram participar, só a terceira aceitou].

No regresso do pareat, o Sol, dono da festa, interrogou-o e foi informado de que os convidados já estavam a caminho. Os peixes dormiram em Murena, e dali mandaram um rapaz pelo Ronuro acima até ao R. do Ferro, para dizer ao campeão que lá morava, que fosse com eles. O rapaz retomou, mas com a resposta de que só vinha o filho do campeão Karatuaruwyap: mas esse filho era só um ovo. Partiram de Murena, e em Marakatavi escarificaram-se: por isso é vermelha a água de lá. Continuaram subindo o Kuluene, passaram pelo Yakupep. 225: No Jacaré descansaram, e ao meio dia o chefe tornou a pôr-se em marcha com as mulheres. Os homens seguiram-nos. 
Chegados ao Karãyãyãy dançaram ho'at; e foram dormir em Mariwahet. Aqui, do ovo do Karatuaruwyap nasceu um menino, e de paus queimados prepararam material para se pintarem. É por causa disso que o subsolo é preto em Mariwahet. Na lagoa dos Matipu, Haikãng, o Peixe-Cachorra, achou-se muito cansado.

Era de manhã. Katsinĩ estava pescando no porto dos Kalapalo, quando o peixe passou por ele. O Ararapira, Peixe Arara, puxou conversa e ao saber o que fazia, avisou-o de que o peixe que esperava, ia todo a caminho da festa.

E convidou-o a ir também, para fazer flauta uruá. Quem mandara ali o Ararapira haviam sido os filhos de Katsini, que ele gerara enfiando os dedos no ânus da arraia.

126b: Katsini teve medo de entrar nágua, mas Ararapira insistiu, dizendo que a água era como o seco, e que seus filhos já iam adiante. Katsini, decidindo-se, acompanhou os peixes, que eram gente também. As piranhas, com raiva porque pescava e comia peixe, queriam devorar Katsini: por isso teve de dormir afastado dos peixes. No dia seguinte, prosseguiram e pernoitaram longe, e no mato dançaram ho'at: nessa ocasião os filhos pederam-lhe e ele fez-lhe as flautas uruá, e os filhos alegraram-se. À noite dançaram ho'at, em todas as paradas. Apesar de tudo, Katsini estava desgostoso porque seus filhos não haviam ficado também para trás.

225: Chegaram perto da casa do Sol, e pararam ouvindo o sapo cantar. 127: Os peixes perguntaram a Katsini se ouvia os sapos Maritawata que estavam cantando, dizendo-lhe que os sapos cantadores eram iguais a ele, Katsini. 225: Ali se detiveram e sentaram, bem próximos à casa do Sol, para que toda a gente se pintasse.

126: o Sol e a Lua eram os donos e dirigentes da festa de sua Mãe. Quando os peixes chegaram à cachoeira feita pelos Gêmeos para os prender, o chefe mandou o Karatuaruwiyap abrir passagem. Ele bateu o pé e arremeteu, conseguindo pequena brecha; atrás foi seu irmão e alargou-a. Então os peixes sairam, com o Muruta, o Bagre, à frente, mas o Muruta meteu-se por um buraco, e mandaram-lhe que passasse a morar sob as pedras. Por isso Karikari e Muruta moram embaixo de pedras.

126: Aqui, o Ararapira anunciou que dormiriam ainda no caminho uma noite e o Wirake, o peixe elétrico, bravateou que ia enfrentar a Onça Vermelha, e que lhe arrancaria todas as braçadeiras de plumas. Moikapit, espécie de enguia, afirmou que lutaria com o Sol. Mas isso não podia, porque o Sol era yayat, dono da festa. 225: Mais uma vez o chefe seguiu adiante com as mulheres, e os homens empós deles. 
126b: Chegaram por fim à aldeia, e chamaram os pareat para trazer fogo. [225: comida e bebida]. (225: Na aldeia visitada, só de noite "se diz besteira"; só o pessoal o faz e pede comida - os chefes mantem-se quietos).

Como o pareat não lhes levou fogo, todos ficaram com raiva, e dois rapazes, Tukunarei e Yakunã, foram buscá-la à aldeia. Na casa do Veado só estavam as filhas dele, a quem pediram lume: elas mandaram-nos entrar, namoraram, e acabaram copulando com eles. Feito isto, voltaram para pernoitar no acampamento afastado da aldeia ${ }^{12}$.

225: De manhã cedo pintaram-se para o ho'at, com urucu, carvão, óleo de piqui, óleo de pau, e mal o sol subiu um pouco, estavam prontos. 127: Vestígio do que aconteceu são as árvores que dão "leite" que serve para pintar a carpa, e as marcas de urucu e urukuyup nos troncos onde limparam as mãos. 225: O pessoal do Sol também já estava pronto. 127: Veio então o pareat chamá-los para dançar ho'at.

225: Os convidados foram para a aldeia, precedidos pelas chefes e as mulheres, e pararam perto da casa da Sol. O pareat trouxe-lhes bancos, e fez um chefe entrar, conduzindo-o pelo pulso; depois trouxe os outros dois, que se sentaram ladeando o primeira. Atrás deles e na chão, sentaram-se as mulheres.

126b: Primeiro dançaram ho'at os da aldeia, que eram a Veado, a Anta, etc. Logo foi a vez dos peixes, que dançando passaram por detrás dos Kwarïp e de seus próprias chefes, agrupando-se depois por detrás dos chefes e das mulheres.

A Lua, que dirigia a festa, chamou os campeões, e o Sol, seguida de mais cinco, foi o primeiro deles. [225: o Sol fez a chamada dos campeões, começando pela filho da Onça (sic). Depois pediu lutadores ao chefe visitante, para lutarem com o filho da Onça].

O Sol lutou com o Karatuaruwiyap e ganhou; depois foi a vez dos outros campeões. 225: A estes sucederam os outros homens, lutando misturados pelo pátio: os "lutadores" (campeões) ficaram olhando, só a "gente" (comum) lutava, enquanto as mulheres assistiam, de junto dos chefes.

126b: A Onça Vermelha lutou com o Wirake e arrancou-lhe as braçadeiras de plumas, menos uma; se não as arrancasse, o Wirake, ao dar choques, mataria. O Sol fez vento mágico para acabar com as braçadeiras da poraquê, e chamou Moikapit para lutar. 127: O Sol perdeu e desmaiou, "morreu um pouquinho". Quando melhorou, procurou a adversário, mas

\footnotetext{
${ }^{12} \mathrm{O}$ texto omite a descrição da primeira dança ho'at, que é realizada à noite, no dia da chegada, e passa diretamente ao ho'at da manhã seguinte.
} 
este correra e escondera-se atrás dos "donos do banco" dos peixes. Quando o Sol perguntou, foi-lhe dito que o Moikapit partira, mas o herói descobriu-lhe o esconderijo pelas marcas de tinta [126b: carvão. 127: urucu]. Limpou-as, das bordas do furo por onde se metera o antagonista. 126b: Com uma redinha, o Sol capturou perto da água um Moikapit pequeno, e, com ele enrolado no braço, ensinou que para ser campeão é preciso estudar e passar remédio. 225: ainda cedo a luta findou, e o chefe da festa mandou que os dois grupos se separassem.

Assim foi o fim do Kwarïp da Mãe deles. 225: Dois homens apanharam flautas urua e foram dançar, levando mulheres a acompanhá-los, e logo depois outro par entrou na dança. Primeiro foram à casa do Sol, depois a outra, onde lhes deram comida, e desta às demais casas, recebendo nelas, sempre, alimento. Percorridas, dançando, todas as residencias, apanharam as ofertas para o chefe, e voltaram a dançar; mas desta vez não lhes foi dado peixe. 127: Apesar da recomendação do Sol, houve quem dançasse com o Kari que é perigoso para as mulheres pois Ihes apertam a mão e as arrasta para o rio. E o Kari assim fez, levando-as para baixo d'água.

126: Chegaram então as ariranhas à procura do peixe, que, com medo, se escondeu todo no Tapwĩ (casa das flautas), onde Katsini o fechou valendo-se de um assador de beiju. Depois. Katsini aguardou as ariranhas, só no terreiro. Mas chegaram, perguntaram pelos peixes, cujos rastos viam, mas Katsini fingiu ignorar. 127: Convidando-as a irem a um ranchinho velho, Katsini emitiu gazes: interessadas, as ariranhas quiseram saber por onde saiam [126b: por onde safa aquele cheiro bom e desconhecido]. Ele repetiu a emissão de gazes, e explicou que era pelo ânus, perguntando-lhes se elas não eram assim, também. Não, não soltavam gazes, por falta de ânus. Katsinĩ, então, bebeu mingau e quis evacuar, pedindo licença às ariranhas para retirar-se. Elas pediram para ir ver, e foram.

Dizendo-lhe - entusiasmadas que as fezes dele já saiam, perguntaram como é que fazia ânus. Ele mentiu: - "Furando com a ponta do arco". Queria matá-las, porque também gostavam de peixe. Elas pediram-lhe que lhes fizesse ânus, mas, duvidoso, Katsinĩ quis saber se aguentavam, avisando as ariranhas de que teriam de ficar de quatro pés no chão. Indagou delas como evacuavam: não o faziam, só vomitavam. Katsinĩ mandou-as deitar-se, de olhos fechados, e, prevenindo-as de que desmaiariam, aguçou o arco e veio de lá, furando, furando, matando uma por uma. Quando só restava a derradeira, os peixes gritaram-lhe que as matasse todas. Alertada, olhou em redor, viu o que se passava e escapou 
para o rio. Katsinĩ atirou-se em perseguição, mas só a conseguiu ferir levemente. 126b: Fez-lhe ânus, mas fino como furo de conta de colar; e por isso as ariranhas hoje não evacuam, vomitam. 127: Assim as ariranhas se transformaram em bichos, e os peixes, contentes com Katsinĩ, abraçaram-se e ficaram onde estavam: é por esta razão que no alto Kuluene há tanto peixe.

[225: Terminada a festa, o Peixe Cachorra avisou o Sol de que se ia embora, ao que ele anuiu, e os visitantes partiram, primeiro os homens, depois as mulheres e os chefes. Pernoitaram no Jacaré, e, no meio do dia seguinte, passaram pelo Murena. À noite foram dormir no Diaurum e na tarde do outro dia chegaram a casa).

125: quando a festa acabou, os Gêmeos atiraram o kwarïp num laguinho, para que as demais tribos o pudessem ver, e fizeram um matinho ao redor, para ocultar o lago. Nenhum Kamayurá viu o kwarïp até hoje, mas um Trumaí sim.

127: Assim é que eles começaram o Kwarïp.

\section{0 - NOMINAÇÃO DOS GÊMEOS (v. ref. 129)}

Um dia Awara, a raposa, foi à casinha do Sol e perguntou-lhe pela Mãe e pelo nome. Ele respondeu-lhe que ela morrera, e que por isso se chamava Tïre' im, "sem mãe". Awara achou que aquele nome não prestava e ofereceu-lhe o seu, que o Sol aceitou: era Tape akanã para ele, Tape iyaok para a lua. [127: encontraram o Tatu que ficou sabendo chamaremse Tïrë ïm. Ele batizou-os Tape akanã (Lua) e Tape iyau (Sol). Em casa a Mãe de Criação quis saber quem the dera aqueles nomes. Disseram, e por isso respeitaram o Tatu, não o matando].

O Sol foi caçar e encontrou Kwarayumiá, o grilo, que lhe perguntou o que fazia. Ele disse que caçava, e o grilo quis saber como se chamavam, ao que o Sol retrucou: Tape akanã e Tape iyaok. O Kwarayumia declarou então que tinha um nome bom, seu, para lhes dar, e o Sol indagou qual era. O grilo disse-lhe que seria Kwat para o Sol, e Yaï para a Lua, seu irmão mais novo. O Sol achou bem e passaram a chamar-se assim. [125: a perdiz Kuyatiti batizou-os Kwat e Yai. 126: os meninos ainda não tinham nome; no Murena perguntaram-lhes qual era e responderam: Tsaukuma. Então Kwarayumiá nominou-os Kwat e Yaï, e o, Gêmeos aceitaram aqueles nomes. 311: ao caçar, o Sol = Deus (Riti) encontrou o gafanhoto Tucura, que ficou sabendo não terem nomes; e ele deu-lhes o seu, Rititaurinhe]. 


\section{COMENTÁRIO}

\section{0. - ORIGENS DO ANCESTRAL}

As tradições Bakairí e Kamayurá deixam claro que a ação do mito decorre num espaço e num tempo perfeitamente distintos do atual, não apenas por se situarem num passado remoto, mas por suas próprias características particulares. A dos Waurá, com que aliás se inicia o relato, omitese quanto a isso. Para os Bakairí, tudo começa no céu, e só após haverem tomado forma humana e obtido o sol, a rede e o sono é que os Gêmeos passam à terra com sua gente, enquanto o céu sobe e se instala na respectiva posição. Exprimem o mesmo, mas de modo diferente, os Kamayurá: é numa terra pequena para seus propósitos que o Ancestral começa a fazer seres humanos, e por ser pequena ele aumenta-a e transforma-a, dandolhe suas dimensões como um dos atos iniciais para a organização do mundo que a mitologia revela. Antes, porém, e seguindo ainda a tradição Bakairí, que é confirmada por um mito Kamayurá, dá-se a organização do ciclo temporal diário, quando os Gêmeos roubam e põem em seu curso, dando origem à sucessão dos dias e das noites, o sol que só esporàdicamente passava, carregado pelo Urubu-rei. É de notar que os Gêmeos, que depois se identificarão nominalmeme e talvez efetivamente com o Sol e a Lua, agem aqui sobre o astro como sobre um objeto, de que se tomam "donos". É portanto na noite indistinta e num espaço ainda não organizado que se dão aos primeiros passos da gênese do Ancestral, e locuções "de manhã", "no dia seguinte", "de noite", devem ser entendidas como marcos na diacronia interna do mito, e não como realidade externa já existente nesse momento do tempo mítico.

Ao começar o mito com a variante 221, acompanhada fragmentàriamente pelas de n.. 111, 222, 321 e 322a, aparecem apenas três entidades distintas e opostas entre si, a tribo dos Jatobá, a dos Piqui e a dos Morcego. O acasalamento secreto entre a filha dos primeiros e o Morcego que vagueava na noite resolve, parcialmente, essa oposição, mas ao mesmo tempo acentua a distinção entre o grupo dos animais e o dos Paus tomados globalmente, pois o acasalamento se faz entre os termos mais distantes do conjunto. Por sua própria natureza de paus, Piqui e Jatobá se poderiam considerar parentes, talvez tão próximos que qualquer relação de tipo sexual entre eles ficasse excluída. Embora o texto nada esclareça, a hipótese, que parece viável, fica ao mesmo tempo exposta a dúvidas, pois é entre os Piqui que o Jatobá primeiramente procura o sedutor de sua filha. 
De qualquer maneira, a sedução de que resultará o Ancestral, ao resolver em parte a oposição entre vegetais e animais, gera um desequilíbrio que afeta as relações de reciprocidade previstas, na cultura xinguana, como resultantes de um nascimento, pois, apesar de reconhecer o filho, o Morcego não casa com a filha do Jatobá. Limita-se a indenizá-lo pelos favores sexuais recebidos e por ter engravidado a moça, o que é inuficiente para anular o desequilíbrio surgido, porque mesmo nos casamentos em condições normais o noivo está obrigado a um período de residencia uxorilocal, em que deve cooperar com o sogro e por extensão com seu grupo coresidencial. O que equivale a uma prestação de serviços em troca da noiva cedida por seu grupo familiar, e se insere no padrão xinguano que exige uma constante equivalência nas prestações recíprocas de serviços e bens. Carneiro e Dole (1956-7, 1956-8) constataram o fato entre os Kuikúro, Quain (1955) entre os Trumaí, e observamos o mesmo na prática diária da aldeia Kamayurá. Mais adiante, no correr da narrativa, este desequilíbrio que agora aparece adquirirá sua importância, determinando em grande medida, cremos, o comportamento do Ancestral em seu encontro com a Onça.

A oposição de tribos e sua resolução por meio de casamentos e de formas ritualizadas de interação expressam-se e resolvem-se, no mito, tal como o fazem entre os grupos xinguanos da atualidade. Uma das características mais marcantes de nossas variantes Waurá é sua atenção pelo pormenor cerimonial, que descreve com exatidão quase etnográfica: vemos o Jatobá enviar seus pareat como emissários às aldeias vizinhas, e serem recebidos pelo chefe principal, que chama os chefes de grupo residencial e os interroga sobre sua disposição e intenções. Eles respondem num tom ritual, menosprezando o valor dos presentes que poderão levar em sua visita, mas anuindo, e o "capitão" dá por aceite o convite. É então pintado nas costas do pareat e de seus dois acompanhantes um desenho simbólico, e eles partem deixando determinado o dia em que os convidados comparecerão; a partida destes é calculada de modo a que, seja qual for a distância, cheguem ao entardecer ou mesmo à noite, acampando fora da aldeia. Até ao dia seguinte, quando serão recebidos nela, toda a interação entre a tribo acampada e a dos hospedeiros fez-se por intermédio dos pareat, às vezes coadjuvados pelo seu "capitão". Bem cedo no outro dia, os chefes visitantes apresentam-se à entrada do terreiro, seguidos pelas mulheres, e são conduzidos a banquinhos nele dipostos. Daí assistirão a uma competição de luta corpo a corpo, na qual se defrontam os homens dos dois grupos. Não nos deteremos na descrição desta luta, que fizemos anteriormente (1966): importa saber que serve como catarse das tensões 
acumuladas gradativamente e exacerbadas no período imediatamente anterior, e que desempenha importantes funções na afirmação e manutenção da auto-consciência étnica tribal. Finda a luta, a oposição e antagonismo que assim se expressaram e resolveram dão lugar a danças entre os homens visitantes e as mulheres dos visitados ${ }^{13}$, e a oferta de comida e presentes (variáveis segundo as ocasiões) em que se nota, sempre, aquela preocupação de manter a equivalência nos bens e serviços cerimoniais trocados. Cingindo-se a estes mesmos padrões a interação efetiva dos Morcegos e Jatobás, ela corresponde à realidade etnográfica observável e corrobora a existência de uma prévia oposição entre eles, que tende a resolver-se pelo intercâmbio sexual entre representantes dos dois grupos, seja ou não através do casamento.

Dessa união nasceu o Ancestral, que considerado na totalidade das variantes do mito, é bastante ambíguo em sua aparência física. Fruto das relações de um vegetal com um animal, será ele que dará origem à progênie humana esculpindo de troncos as primeiras mulheres. Mas, se os Kamayurá, e os Awetï segundo parece, o creem antropomorfo, os Bakairí acreditam que "é de cor preta, tem pelos não muito numerosos, e faz fios como a aranha. As aranhas aparecem anualmente e dão cria; em agôsto e setembro, quando vem a chuva, fazem fios, subindo, depois, para o céu, ficando o fio pendurado atrás delas. Kamuschini (o Ancestral) é como essas aranhas" (Steinen 1940: 479).

Nesta identificação do Ancestral à aranha, é importante que se trate desse e não doutro animal, pois é coerente com as duas afirmativas seguintes, a de que a aranha sobe ao céu deixando atrás de si um fio, e de que o faz em agosto e setembro. Um mito Kamayurá, recolhido recentemente, conta como o Sol tentou que os homens fossem capazes de rejuvenescer, pelando-os em água quente, mas não o conseguiu porque tiveram medo. Só as cobras e as baratas tiveram coragem, e por isso se renovam trocando de pele periodicamente. Esse mito não cita explicitamente as aranhas na classe dos animais "renováveis", mas o que sabemos do conhecimento empírico de seu ambiente pelos índios, permite que nela as incluamos, também. E se o fizermos, encontraremos o ponto de ligação com uma outra versão Bakairí do Mito de Origens, obtida por Capistrano de Abreu (1938: 254-255). Nela, diz-se que o Ancestral (Nakoeri) nasceu antes de todos e era o "senhor da reza", tendo criado os bichos e os Bakairí, cujas almas vão ter com ele ao céu, para onde ascendeu valendo-se de uma escada de algodão fiado. Onde está, toma banho ao amanhecer, e,

${ }^{13}$ V. nota 19. 
sem morrer, "de manhã vira menino, de tarde vira velho": "todos os dias se pela Nakoeri"... Os temas da subida por meio de um fio, e da volta à juventude encontram-se, aqui, presentes mais uma vez.

Assim, o Ancestral é um ser capaz de renovar-se, e de estabelecer comunicação com o céu exatamente naqueles meses em que ela se dá pelo findar da seca e a chegada das chuvas. É também neste período do ano que se realiza o grande cerimonial do Kwarïp, dedicado aos mortos, que são confirmados em status definitivo de mortos e residentes no céu. Ali, como Nakoeri na versão Bakairí, as almas dos Kamayurá não morrem, rejuvenescendo sempre, e isto concorda com todo o simbolismo do Kwarïp que é o de uma re-criação total do universos xinguano (v. Agostinho 1966). Pela própria identificação com um aracnídeo o Ancestral exprime sua capacidade de, por transformação, originar uma realidade nova ou renovada, e de estabelecer a mediação entre a morada dos vivos e a dos mortos.

Aproximar Tumeng (v. 321) do Ancestral é mais complicado e indireto, pois reina nos dados de v.d. Steinen certa confusão, quanto ao nome, status e papel desse personagem, que em parte se deve ao caráter atomizante e algo desconexo das informações de Caetano Memo. Na variante 321 Tumeng é filho de Semino (Morcego) e de Ewaki, equiparada a Eva, enquanto Kamuschini (o Ancestral) se equipara a Adão. Dos pais deste último, nada era sabido. A v. 322b cala quanto a Semino, aparecendo em seu lugar Tumehi ou Tumeng, que é marido de Ewaki e avô dos Gêmeos, sendo considerado "da parentela mais antiga de Kamuschini, Mero e Ewaki", e apresentando-se sob a aparência de um Morcego cinza-negro.

Com estes dados, e tomando como base de comparação e referência as v. 221 e 111, poderíamos tentativamente elaborar um quadro genealógico do Ancestral, em que o asterisco indica um termo hipotético, introduzido por não estar explícito, desta forma, em nenhuma das variantes estudadas:

Se considerarmos agora que a v. 221 apresenta como progenitores do Ancestral o Morcego e a moça que seduziu, que o mesmo acontece com a variante Awetï 111 a que se refere o Quadro 3, e que é ainda algo semelhante o que ocorre em 322b (Tumehi Tumeng = Morcego "da parentela mais antiga de Kamuschini, Mero e Ewaki"), poderemos localizar a fonte da falta de clareza notadas em v. d. Steinen, no texto 321. O que se parece ter dado é um desdobramento do Morcego em dois personagens, um dos quais mantém seu papel - Semino -, enquanto o outro usurpa o que caberia a Kamushini como filho do Morcego e de Ewaki; e, ao mesmo tempo, Kamuschini passa a ser equacionado com Adão, o que equivaleria a considerá-lo marido de Eva e portanto de Ewaki. O que se verifica é que, 
além do desdobramento do Morcego, se deu uma permutação de posições entre um dos resultados desse desdobramento e o Ancestral, i.é, entre Tumeng e Kamuschini. Deve-se isso talvez a que Adão combina nas crenças cristãs a qualidade de Ancestral à de "mais antigo de todos", enquanto a mitologia xinguana distribui essas mesmas qualidades entre o Ancestral propriamente dito e o Morcego. Dai a hesitação, num informante submetido, como o foi Caetano Memo, à constante pressão das forças aculturativas.

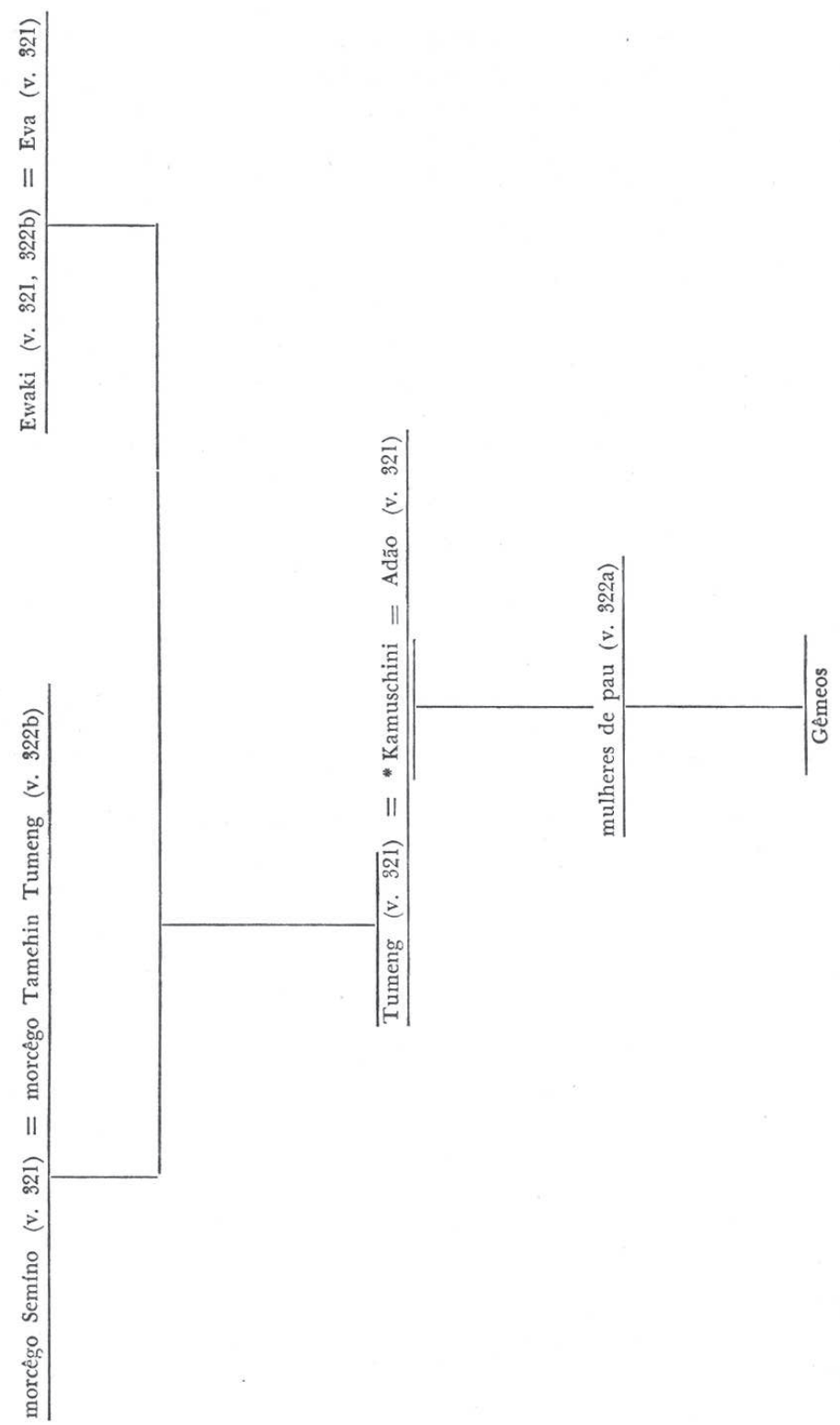


Sintetizando os dados discutidos até agora, caberá reter, porque fundamental para comprender o que se passa quando o Ancestral e a Onça se encontram, que nos começos havia dois grupos opostos Jatobá e Morcego); que um deles cedeu uma mulher ao outro; e que portanto, num sistema onde se buscasse o equilíbrio na troca de mulheres (restrita ou generalizada), ficou o grupo do Ancestral na posição de devedor, não obstante o "pagamento" em presentes. Isto explicaria a razão pela qual o Ancestral não casa, em nenhuma das variantes, pois se o fizesse acentuaria ainda mais aquele desequilíbrio - e explicaria também o motivo que o leva a oferecer suas "filhas" à Onça, como mulheres.

Apesar de não casar, e de fazer de troncos as moças que cederá à Onça, o Ancestral tinha outras, as que gerara no interior de um cupim. Seria função deste episódio justificar a existência das filhas que recusam casar com a Onça e que são anteriores às que esculpiu, por um lado; e por outro, acentuar o papel do pai na geração, em detrimento do da mãe. Isto daria talvez razão a Laraia (1970:127) quando se inclina a aceitar uma enfatização do pai como procriador, na mitologia e na cultura xinguana, malgrado a bilateralidade, de seu sistema de parentesco. A isso se poderia acrescentar que, sendo solteiro, a vida do Ancestral não lhe seria econômicamente possível dentro dos padrões tribais de divisão sexual do trabalho, se não contasse com a cooperação de mulheres: como acentua o mito, as moças cozinhavam para ele.

\section{0. - AMPLIAÇÃO DA TERRA}

Introduzimos entre parênteses este pequeno mito independente por se relacionar diretamente com a primeira ação transformadora do Ancestral; para povoar a terra com os seres humanos que faria de troncos, inicia a organização do espaço xinguano dando-lhe sua base física. Ela será depois complementada pelos Gêmeos, com o roubo da água e criação dos rios (Steinen 1940: 481-482), e a distribuição das tribos por suas respectivas aldeias, além de outros atos menores. Essa ação do Ancestral opera-se segundo dois eixos, um horizontal e o outro vertical, referidos à extensão e à estratificação da terra: o subsolo de cor avermelhada e impróprio para a agricultura, que segundo nossos informantes aflora em Murená, foi recoberto pelo solo escuro e rico de humus que os índios escolhem para suas roças.

Quanto ao segmento da v. 322, que suprimimos e que trata da troca do céu pela terra (Steinen 1940: 481), apresenta os Gêmeos, e não o An- 
cestral, como agentes transformadores, e uma outra fase da organização do espaço: antes juntas e lado a lado, as duas regiões cósmicas separam-se e assumem suas respectivas posições.

\section{0 - O ANCESTRAL FAZ GENTE DE TRONCOS}

Verifica-se no Quadro 2 que a partir deste momento funciona a v. 127 como referência na reconstituição do arque-mito, com a característica de se afastar, e consigo o restante da tradição Kamayurá, das tradições das outras tribos. Isto porque considera que não só as mulheres iniciais, de uma das quais nascerão os Gêmeos, foram feitas de troncos, mas sim todos os índios xinguanos. Nas demais tradições, os índios, sem exceção, foram criados de haste de flexa, enquanto na Kamayurá esse processo só se aplicou aos índios bravos, isto é, não xinguanos. Esta ressalva é necessária desde já, muito embora o assunto só adiante venha a ser retomado pelo mito, o qual na parte de que nos ocupamos agora, não se apresenta como uma narração linear.

Várias explicações são aduzidas em seu decorrer, e mais importante de todas é a que dá o motivo pelo qual os mortos não mais retomam no Kwarïp. Transgredida a norma ritual que impede a participação ou aproximação de quem tenha tido recentes contactos sexuais, cessou a possibilidade de transformação, c a morte terrestre definitiva instaurou-se, ficando o Kwarïp como rito comemorativo. Como se verá, o Kwarïp dedicado à Mãe dos Gêmeos realiza-se já e apenas com a intenção de lhe relembrar as origens.

Posto isto, o mito passa às diferenças entre os homens, ou melhor, entre os índios do Xingu, que, oriundos de troncos, se distinguem entre si pela cor da pele, que é conforme ao tipo de árvore empregado. Isto vai encontrar sua correspondencia nas outras tradições e num ponto mais avançado da narrativa, quando os índios são feitos de duas qualidades de haste de flecha (ubá e cambaiuva), e os civilizados de madeira de coronha. Estabelece-se assim um principio de distinção e classificação dos homens, que veremos acentuar-se progressivamente até quase ao fim do mito, quando um esquema classificatório que combina uma série de critérios é apresentado.

Diz ainda a v. 211 que, criados os homens, vieram os peixes e as onças e lutaram; este confronto entre os peixes e onças repetir-se-á na comemoração do Kwarïp pelos Gêmeos, e para esse momento deixaremos sua discussão: deve-se notar, entretanto, que a interação entre os dois 
grupos se faz seguindo o mesmo padrão observado na visita dos Morcegos aos Jatobás.

Prosseguindo em sua tarefa simultâneamente transformadora e organizadora, o Ancestral fabricou os atributos culturais que serão traços distintivos das tribos, e, para completar a obra, dirigiu-se ao mato em busca do material faltante, que na maioria das variantes é a corda de tucum para o arco, e deparou-se com a Onça. Este encontro tem como pontos essenciais a hostilidade da Onça ao Ancestral, e o fato de serem, real ou fictìciamente, parentes próximos: o último, quando se dirige à Onça, chama-a de "filho da irmã". Considerando a cultura xinguana preferencial o casamento entre primos cruzados, ficam os dois adversários na posição de potenciais aliados pela troca de mulheres, ou seja, de sogro e genro, o que não é incompatível com a hostilidade do primeiro momento. As relações de um cônjuge com a família do outro são latentemente antagônicas nesta cultura tribal, como o demonstram outros mitos e as relações de evitação dos sogros com o genro e a nora, e entre cunhados. Semelhante antagonismo é ainda mais marcado nos casamentos intertribais, comuns no Xingu, e é neste caso que se encontram a Onça e o Ancestral: para este a alternativa era ou a hostilidade aberta conducente ao choque armado, ou a oferta de mulheres em aliança, e, escolhendo esta última, fez a proposta ao ambivalente opositor.

Tal escolha, e o sentido em que se dá a transmissão de mulheres não parecem frutos do acaso, pois as bases para este proceder ficaram lançadas quando o grupo social do Ancestral ficou na situação de devedor num circuito de troca de mulheres. Admitindo-se um sistema de troca, havendo obtido antes uma mulher dos Jatobás, o grupo do Ancestral acha-se agora obrigado a corresponder cedendo, não importa que a um outro grupo qualquer, no caso o das Onças. Se o Ancestral houvesse casado, ou se fosse a Onça a dar-lhe esposa, o desequilíbrio existente na reciprocidade prevista aumentaria, e iria de encontro aos padrões socialmente aceites.

Será também nesse quadro de relações tensas entre aliados por casamento que teremos de entender a recusa das filhas do Ancestral quando as manda para casa da Onça, e o bem fundado medo que tem à sua mãe, do que resulta a necessidade de esculpir novas filhas para cumprir a promessa.

Cortados e transportados os troncos, a primeira providencia do Ancestral é cobri-los com as folhas mágicas de yenemïo $p^{14}$, cujas virtudes aparecem noutros mitos como sendo curativas, e capazes de ajudar na

\footnotetext{
${ }^{14}$ Estas folhas recobrem os braços dos dançarinos de Tawarawanã. Mal estudada, esta dança parece ligar-se a rituais coletivos de cura, e diz-se de origem Kuikúro. Stein (1940:130) viu-a entre os Nahukwá, e, chamando-a "dança da rêde de pescar", publicou uma gravura fiel (prancha VIII). Alguns dos personagens cobrem o rosto com pedaços de rede de pesca, entre os Yawalapití.
} 
recuperação ou obtenção da vida. Depois, procede a talhá-los e enfeitálos, dando-lhes feição de gente. O padrão ideal de beleza feminina transparece aqui, com a busca de um cabelo negro e liso, e de dentes que, embora perecíveis, dessem um riso branco e bonito. Os adereços complementaram a obra, e deve-se atentar para a atitude da entrecasca Tamehawp ante o cheiro da vagina, que também é repelente para os espíritos tutelares (mama'ẽ), havendo a possibilidade de uma relação entre isto e as restrições sexuais que atingem os implicados num ritual. Faltamnos dados para avaliar se Tamehawp (na época um ser antropomorfo) era um mama'ẽ, mas seu comportamento poderia significar que sim. Fazendo de Tamehawp a diminuta proteção pubiana conhecida como uluri, o Ancestral acaba parcialmente o cinto característico das xinguanas, mas deixando-o numa forma intermédia: não é mais o das meninas pré-púberes, só de fio de buriti, por ter o pequeno triângulo de entrecasca; mas também não é o das mulheres adultas, pela falta do cordão perineal. Isto caracteriza bem o estado transitório em que se encontram as moças, pois vão sair de uma reclusão (v. 311) que se pode equiparar à pubertária, para ir em busca de marido, tal como as que desempenham importante papel nos rituais elo Kwarïp, distribuindo castanha de piqui (v. Agostinho 1966). A função do cordão perineal será em breve esclarecida pelo mito.

Pintando-as com a variedade de urucu própria das mulheres ( urukuyup), e com o pequeno ângulo de tinta negra nas faces (tïwïtïwï' $i$ ), o Ancestral no dia seguinte manda-as para casa da Onça. E o grupo de moças, cujo número oscila segundo as variantes, parte e começa suas vicissitudes, que sucessivamente as vão eliminando, exceto duas, uma das quais será a mãe dos Gêmeos. A primeira perde-se por desleixo, ou afoga-se por teimosia e descuido que trazem, na avidez com que bebe, algo da incontinência que vitimará suas companheiras, e que está sempre ligada a um motivo sexual: quer o da exigência continua de cópula por parte dos animais que encontram, quer o do acidente fatal na queda da árvore ${ }^{15}$.

Mas quando este acontece, já haviam resolvido introduzir regras limitadoras das relações sexuais indiscriminadas e constantes, tomando como instrumento o cordão perineal do uluri, cujas funções são portanto as de um cinto de castidade. Um homem não deve tocar nesta peça de vestuário feminino, sob pena de ficar panema, isto é, sem sorte, o que implica que o ato sexual só é possível com o consentimento da mulher, que deve despojar-se de seu indumento protetor. É esta, pois, mais uma facêta da imposição de ordem, pelo mito, a um mundo em organização.

${ }^{15}$ A primeira das vitimas caracteriza-se em qualquer das variantes pela incontinência oral (fica gritando ou bebe àvidamente), enquanto as outras sofrem por uma incontinência genial. 
Quando chegaram ao porto da Onça, esperaram o futuro marido, que estava jogando bola. Este jogo não está suficientemente estudado, e o mito que a seu respeito obtivemos parece-nos incompleto; o mais que se pode concluir é que funcionaria no sentido de canalizar a agressividade existente entre grupos sociais muito próximos mas distintos, à semelhança da luta corporal e do yawari. No mito do jogo, a disputa opõe um rapaz ao grupo consanguíneo de sua mulher. Seria possível, talvez, a existência de uma relação com o jogo de bola Paresí (Rondon 1948: 101, 106-7), dotado muito provavelmente de conteúdos cosmogônicos e divinatórios.

Enquanto esperam no porto, as moças entram em contacto com uma mulher (anu ou seriema) que se banhava na lagoa, e que vai avisar a Onça da presença delas. Ao nível em que nos situamos em nosso estudo, e com os elementos fornecidos pelas variantes, não poderemos comentar este último episódio, mas outras versões dele, encaradas sob um prisma estruturalista, foram analisadas por Lévi-Strauss (1964: 116 seq.).

Apesar de avisada a Onça, ainda uma vez as duas sobreviventes serão iludidas na sua boa-fé, passando a ter vida marital com um indivíduo que errôneamente confundem com aquele a que estavam prometidas. Mas, ao contrário das anteriores relações esporádicas de suas companheiras, desta vez estabelecem-se laços mais firmes, e ambivalentes, de cooperação e antagonismo com o cônjuge e seus parentes. $O$ antagonismo prevalece com a separação entre as moças e seu primeiro marido, e com a transformação deste e de sua mãe em animais; esse, aliás, é um bom exemplo de como o mito combina a explicitação de atitudes e comportamentos associados a determinadas relações estruturais e explicações de ordem etiológica. Um outro aspecto deste trecho voltará a ocupar-nos quando tratarmos da nominação dos Gêmeos, pois segundo a v. 311 é pela separação numa encruzilhada que as mulheres vão ter, respectivamente, a casa do Lobo e da Onça; pouco compreensível em termos da mitologia xinguana, isto adquirirá seu valor quanto o compararmos ao mito dos Gêmeos nas tribos Tupi. Vemos, ainda, neste episódio, como a distinção entre a Onça e seu Amigo se faz por meio de um atributo, no caso a comida, opondo-se beiju e mingau de minata como alimentos próprio e impróprio de seres dotados de comportamento cultural, como o são as protagonistas da história e o serão os homens em geral.

Aquele esboçado padrão de cooperação de que falamos, torna-se mais nítido quando as moças antes mesmo de passarem a viver com a Onça, lhe ajudam Mãe na preparação das provisões para os caçadores de seu grupo. Assumem, assim, o papel feminino na divisão sexual do trabalho no seio do grupo co-residencial. Há ainda um resquício disto no fato de que o Amigo 
da Onça, inadvertido do que aconteceu em sua ausência, manda carne às mulheres e recebe em troca beiju; prestação e contra prestação que demonstram a complementaridade econômica do grupo conjugal. Assim, o alimento pode ter dois papéis no mito, o de evidenciar aproximação, com o presente caso, ou afastamento, como no da rejeição do mingau de minata em favor do beiju de mandioca. Esta forma de distinção será abundantemente utilizada daqui por diante, definindo-se, por exemplo, as Onças nas v. 221 e 322 por viverem comendo a gente do Ancestral, ou simplesmente carne, como na v. 127 - o que as toma diferentes do homem xinguano, consumidor de peixe por excelência. Aliás o v. 221 diz expressamente que o "peixe" das Onças eram as pessoas da tribo do Ancestral.

Consumado o casamento com a Onça, e grávida uma das mulheres, o marido faz-lhe uma recomendação que prefigura as relações de evitação entre sogra e nora observadas pelos xinguanos. O grupo dos afins é potencialmente perigoso, e a etiquêta, que exige reserva no tratamento mútuo, busca eliminar as oportunidades de atrito através de um estudado distanciamento. Quando a mulher provoca o desagrado da sogra, engravidando de outra tribo (v. 322a), ou cuspindo como se tivesse nojo, é assassinada, e este assassinato deriva na maioria das variantes de uma quebra do respeito exigido pelas normas tribais. Como as competições "esportivas", as relações de evitação previnem a eclosão violenta das tendencias agressivas, acumuladas entre membros de grupos sociais em estreita interação.

Morta a mulher, vários dos personagens liderados pela formiga fazem-lhe o parto dos Gêmeos: este simples acontecimento é por si mesmo extraordinário e significativo, pois a gêmeos não é dada oportunidade de sobrevivência na sociedade xinguana. E este caráter extraordinário que marca o nascimento do Sol e da Lua marcará todo o decorrer de sua vida. Embora saibamos tão somente que nascimentos desse tipo são considerados aziagos pelos índios, temos razões para suspeitar que a personalidade incomum dos Gêmeos míticos está na raiz dessa crença, pois a sobrevivência de um novo par poderia trazer consigo nova série de transformações, que fariam perigar toda uma ordem social e cósmica vigente e aceite.

Nascidos, imediatamente foram os Gêmeos encerrados numa cabaça como as de criar papagaios, aos quais, aliás, se assemelham segundo uma variante Bakairí (322a). Será dentro dessa cabaça que, crescem e começam a andar, e é só ao se libertarem dela que adquirem forma humana. Noutras tradições, o recipiente em que são postos os meninos é de diversas espécies, mas sua natureza revela-se explìcitamente nas v. 125 e 126, que dizem que eles ficaram presos num mïrïsi. Ora o mïrïsi é a tapagem de 
talos de buriti feita no interior das casas, para resguardar os que se acham reclusos num ritual de passagem; por exemplo, os enlutados e os jovens púberes que ainda não atingiram o status de adultos. Demonstramos noutro trabalho (1966) que este período de reclusão equivale, como seria de esperar, a uma morte simbólica, da qual os pacientes renascem transformados, isto é, transportados a um status diferente do anterior. Quando os Gêmeos saem de sua "prisão", andam e falam e se comportam muito melhor do que o faria supor sua idade presuntiva. As relações entre a cabaça em que viveram, a morte simbólica, e a morte biológica, parecem explicar o motivo que impede e proíbe a manipulação das cabaças-gaiola de periquitos, após um falecimento na aldeia. Estando Os Gêmeos na cabaça para, por assim dizer, completar seu interrompido período de gestação, vemos como na simbologia indígena nascimento, morte e renascimento andam próximos e se combinam; a própria mãe dos meninos está morta quando nascem. É de sua morte que surge a vida deles, como da morte ritual um novo aspecto da vida, sob a forma de uma mudança de status na sociedade tribal.

\section{AWETI (v. III) Geneningia de Kwat e Ta.tï}

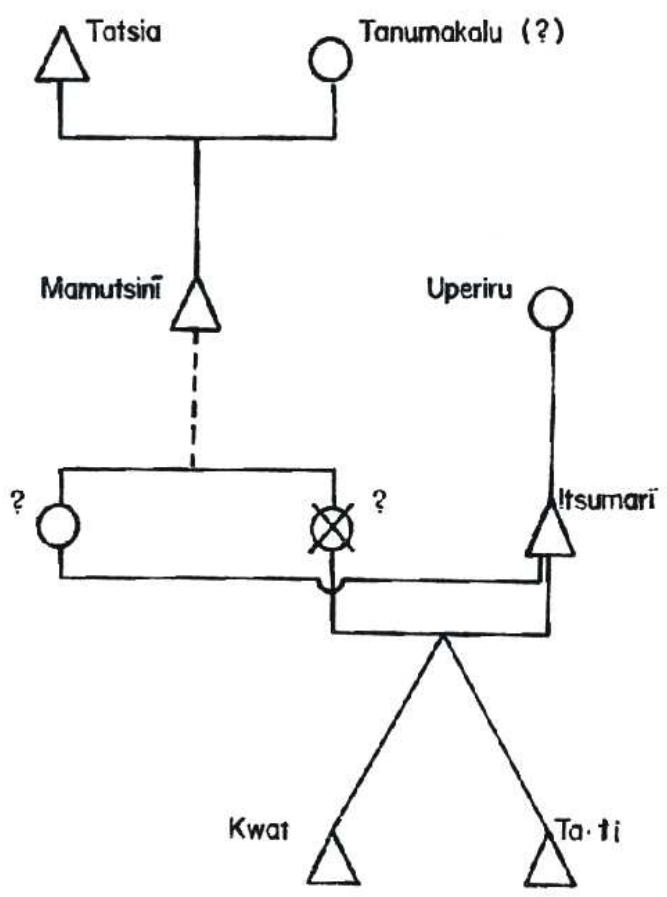


Quando se passa aos funerais da mãe dos Gêmeos, o marimbondo vê-se escolhido para a construção do mito pelo aspecto e hábitos de que é dotado, pois tem a cabeça vermelha, como a dos enterradores após os rituais de pintura, e faz toca em buracos que escava. Na estação seca pelo menos, a sua é uma presença constante nos terreiros das aldeias. O mito pormenoriza a maneira pela qual se envolve o morto na rede, que é, depois de costurada obedecendo ao motivo tapaka ${ }^{16}$, levada em procissão em torno do interior e exterior da casa, ao som de cantos que se destinam a afastar a alma (ãng), que de outra forma ficaria rondando os vivos. Esta mulher, por seu alto status de "filha" do Ancestral, foi enterrada de pé, e daí se origina um dos tipos de sepultura destinado à classe, cerimonial sobretudo, dos morerekwat ou "capitães". Nas variantes em que a defunta fica aos cuidados, não do marimbondo, mas da Onça (v. 311, 322), esta não sabe proporcionar-lhe os ritos necessários: ou a atira para o alto da casa, ou é induzida pelos seus a devorá-la inadvertidamente. Tanto um comportamento como o outro acentuam a distância entre a categoria a que pertencem as mulheres e aquela a que se filia a Onça, a que se mantém fiel às nurmas culturalmente aprovadas e a que delas se afasta. Esta separação que se esboça lentamente, será acentuada pelos Gêmeos e culminará quando, por meio dos homens, atacam a tribo das onças e enviam o pai e a madrasta para o céu.

Por fim, os meninos começam a mover-se e a sair da reclusão na ausência dos responsáveis, e estes procuram descobrir-lhes a identidade; daqui em diante, a irmã da mãe, que neste caso de poliginia sororal desempenhará o papel de Mãe de Criação, assume um status mais importante que antes. A identidade sexual dos Gêmeos vai definir-se por meio da aceitação ou não de atributos culturais, o que é coerente com o processo sistematicamente adotado em outros pontos do mito, em quc atributos dessa natureza se tornam em traços distintivos; no presente caso, isto se exprime assim:

$$
\text { uluri + rodilha : mulher :: arco + flecha : homem }
$$

Só depois desta definição é que os meninos saem de sua reclusão e começam a ter um desempenho ativo, e as aventuras que a seguir vem mostram-nos os Gêmeos iniciando seu trabalho de continuadores da obra do Ancestral na organização de um mundo. Nos contactos com os diversos

\footnotetext{
${ }^{16}$ Desenho geométrico que representa um peixe. É o mereshu de v.d. Steinen (1940:329, 334 figs. 43 e 48).
} 
personagens que vão encontrando, os meninos vão-Ihes atribuindo os traços distintivos que os distribuirão por diversas categoria classificatórias, traços esses que se situam no plano físico, alimentar e de comportamento. E, ao introduzir essa crescente ordem cntre os seres vivos, os Gêmeos estão também em procura; de maior precisão em sua autodefinição, quer por identificação, quer por oposição a esses mesmos seres. Querem saber de seu passado, de seu nome, de suas afiniadades: e não se pode passar por alto que só os que lhes estão próximos, os que são seus "avós", merecem o cuidado do sepultamento.

O próprio pai dos Gêmeos começa a ser separado deles quando lhe determinam que comerá apenas carne, e isto toma-se ainda mais marcado quando, fazendo prevalecer o parentesco que os liga mais de perto à Mãe do que à Avó, se vingam desta: ao fazê-Io, sofrem um acidente e morrem, ressuscitando - repete-se o tema - transformados. Segundo a variante 322, já agora despidos de seu aspecto caótico em que atributos animais desconexos se combinavam, e revestidos de aparência humana. Essa transformação, aliás, não afeta só os meninos, pois atinge a ariranha, a lontra e o tucano, que dela se valem para obter alguns de seus atributos naturais. Não é ela, entretanto, suficiente para definir cabalmente os Gêmeos e sua personalidade, e isto somente será alcançado quando, depois de sucessivas nominações, recebem seus nomes de adulto. Sol e Lua.

Vingados, partem em busco. da Mãe, e quando a localizam demonstram ritualmente seu pesar, que se manifesta bastante indiferenciadamente, pois choram nos vários estilos das tribos conhecidas pelo narrador. Mas uma primeira distinção se faz já sentir, porque primeiro usàm o carplr das tribos da área cultural do Alto Xingu, e só após o das que lhe são marginais, o que corresponde a dois dos níveis mais inclusivos do sistema de classificação étnica e intertribal que à frente analisaremos. Fracassando no intento de devolver a mãe à vida, os Gêmeos tornam a chamar o Tumutumuri para enterrá-la; ele o faz, e submete-se aos ritos de renovação de pintura e levantamento, parcial, das restrições rituais que incidem sobre os enterradores (ïwïkwaraiokarat), A pescaria faz parte das atividades econômicas destinadas a obter as provisões necessárias às prestações e contraprestaçôes de serviços cerimoniais e alimento, que descrevemos e analisamos na monografia sobre o Kwarïp.

Prosseguindo em sua tarefa transformadora e simultâneamente na diferenciação entre si próprios e a categoria onças, os Gêmeos conseguem uma quantidade de canas das usadas para haste de flechas, e delas fazem os índios. Segundo as tradições Kamayurá e Kalapálo, só os que são bravos surgiram então, mas as restantes mantem que nesse momento surgi- 
ram os de todas as tribos, e além deles os civilizados. A v, 311 é algo divergente, pois os índios, em vez de serem criados diretamente de flechas, nascem da tia dos Gêmeos, grávida de cinza das canas por eles queimadas: o que, ao fim e ao cabo, redunda na mesma origem, a partir do material das armas que são distintivas dos seres humanos do sexo masculino. O mesmo princípio vigora na feitura do civilizado, com a madeira da coronha de sua arma típica. Ficam de fora somente os Suyá, que, mau grado os contactos e empréstimos, se mantem geográfica e culturalmente marginais à área, com cujas tribos suas relações oscilavam do convívio pacífico à hostilidade aberta; isto, antes da criação do Parque Indígena, Dos Suyá diz-se que nasceram da cobra que se genera no ventre de uma moça: indo à roça, ela encontrara um ovo, e guardara-o na cesta que carregava; no regresso o ovo partiu-se e o conteúdo escorreu, penetrandolhe nos órgãos sexuais e fecundando-a sem que soubesse como, Repreendida pelos seus, por estar: prenhe e sem marido, ela percebe o acontecido quando ao desejar uma fruta, a cobra lhe sai do ventre, sobe à árvore e a colhe. Com auxílio de um dos irmãos, faz, repetindo o desejo, com que a cobra volte a sair até estar toda fora, e então cortam-na em bocados. Destes se deriva aquela tribo.

Quando a Onça tenta moldar os filhos à sua imagem, isto é, quando tenta, transformando-os, identificá-los a si própria, eles mantem-se fiéis à tendencia que revelam ao longo do mito e reagem hostilmente, marcando em definitivo, a disjunção entre a categoria em que se incluem, e aquela em que se incluirá o pai. O ataque dos índios a mando dos Gêmeos, afirma exatamente o contrário do que Onça procurou ao querer modelarlhes o focinho. Mas ainda tiveram um último ato de respeito pelos laços de parentesco a uni-los, mandando o pai e a madrasta para o céu, enquanto chacinavam o restante de sua gente; nas variantes em que a Onça não se torna em constelação (Alfa e Beta do Centauro), foge e é começo das que hoje vagueiam pelos matos. O importante é que em nenhuma instância sofre ela a sorte de seu pessoal.

Depois da luta, e organizando sob o aspecto da distribuição geográfica o setor social deste universo em formação, os Gêmeos mandam os índios para suas aldeias, sem que, no entanto, eles se apresentem até agora como portadores de todos os elementos que os definirão como etnias. Algumas variantes já os classificam pelo comportamento, hostil ou não (mansos x bravos), nas relações intertribais, notando-se que o civilizado aparece neutral naquele combate - posição que lhe foi assegurada pela forma de sua penetração na área. Ao deixar de colocar o branco numa das categorias "manso" ou "bravo", a maioria das varian- 
tes admite-lhe implicitamente a neutralidade: mas a v. 111 é explícita, dizendo que a carabina não participou do conflito, ficando o tempo todo na mão do Sol.

Ao chegar a este ponto, inseram-se na variante 322 os episódios que eliminamos do texto reconstituído, para nos mantemos, como dissemos, mais ou menos nos limites propostos pela v. 111: são eles os do roubo do astro diurno, do sono e da rede, da troca do céu pela terra, do fogo e dos rios. Instaura-se com isto o ciclo astronômico e fisiológico diário, com a alternância da luz e da escuridão, do sono e da vigília, sendo já o sono uma atividade culturalmente condicionada, pois depende da rede para se efetivar a contento. Esta organização do tempo e de seus ritmos biológicos é complementar de outros elementos essenciais da organização do espaço xinguano, isto é, da separação do céu e da terra e da colocação dos rios em seus cursos. Fica assim preparado o quadro espácio-temporal a ser povoado e explorado pelos homens, até aqui ainda não classificados em etnias culturalmente diferenciadas; mas um traço que lhes é comum, e sem o qual é impossível qualquer existir cultural, é desde já obtido pelos Gêmeos: o fogo.

As tradições tribais xinguanas referem que num dado momento de sua história os Gêmeos deixam o local onde nasceram e vão para junto do Ancestral, que mora ao pé de uma cachoeira. Esta, para os Bakairí, é o Salto do Paranatinga, e para os restantes, a corredeira de Murena. No Paranatinga, quem aí mora é Tumeng e não Kamuschini, mas vimos que em certas circunstâncias estes personagens se confundiram. Os xinguanos atuais, ou pelo menos os Kamayurá, consideram Murena como centro do mundo, e será a partir deste Centro que se dispersarão os grupos humanos, como dele partiram as primeiras mulheres feitas de troncos. É também - ou seu equivalente do paranatinga - o palco de toda a posterior ação dos Gêmeos. Entretanto, no que tange à ocasião em que o Sol e a Lua vão para Murena, a v. 111 afasta-se das outras, que situam o acontecimento após a luta com as onças, enquanto ela o faz quando o Ancestral retira os meninos da reclusão na "mala": isto provoca que se passe em Murena uma parte muito maior da vida dos Gêmeos e de suas realizações. De qualquer modo, Murena (exceto na tradição Bakairí) é o Centro que serve de referência e origem à ordem que se espalha e cria um cosmos estruturado. Chegados a Murena e portadores já da maioria das características que os definem, os Gêmeos recebem um traço distintivo que, sinteticamente, é o significante de seus status de adultos: o nome definitivo, pelo qual serão doravante conhecidos. Isto merecerá adiante atenção mais pormenorizada. 


\section{0 a 4.5 - FESTAS ALUA E IMEO. MULTIPLICAÇÃO DAS TRIBOS}

No ponto a que chegamos, o arque-mito foi reconstituído isoladamente para cada uma das tradições tribais que, embora pudessem ser combinadas, se o fossem perderiam muito de sua nitidez, pelas discrepâncias formais que comportam. Em resumo, trata-se da distribuição pelas tribos de seus nomes e dos elementos culturais que lhes servirão de traços distintivos como entidades étnicas individualizadas. Este sistema classificatório, partindo do particular para o geral, agrupa e reagrupa as sociedades e etnias em categorias cada vez mais abrangentes, até lhes atribuir a todas uma posição na estrutura de relações intergrupais. Como demandaria excessivo espaço e se tornaria redundante esquematizar cada uma das manifestações concretas do sistema, tomaremos como exemplo o da variante que motivou este trabalho, ou seja, a v. 111. Dela, e das restantes, seria talvez possível deduzir um modelo a todas aplicável, mas não o faremos aqui. Antes, porém, de passar à v. 111, teremos de nos ocupar de alguns dados que só figuram na v. 322b.

Fala-nos esta das festas que os Gêmeos, vivendo em aldeias afastadas, se oferecem mutuamente, e dos conflitos que surgem e explicam os constantes deslocamentos dos irmãos, por sua vez responsáveis pela dispersa localização das tribos que vão criando. Não voltaremos, por já o termos feito suficientemente, a chamar a atenção para as tensões latentes nas relações de grupos locais em estreita interação, que se manifestam também nas desavenças dos Gêmeos; nem, tampouco, nos deteremos nos aspectos etiológicos desta parte do mito, por demais evidentes. O que nos interessará será penetrar no significado dessas festas, ou, pelo menos, levantar uma hipótese plausível quanto a possíveis correspondencias no atual panorama etnográfico xinguano. Hipótese esta que não passará de mera conjectura de difícil verificação, por efeito do processo de mudança cultural muito adiantado a que estão submetidos os Bakairí.

Essas festas são as de makanari ou do Morcego grande e pequeno, e a de imigo, a lagarta das palmeiras. Talvez a primeira tenha a ver com a ascendencia do Ancestral, filho de um Morcego. Nenhum dado encontramos em v.d. Steinen (1940) que nos pudesse apoiar; mas o ciclo ritual do Kwarïp, do qual o Mito de Origens é fundamento, inclui entre os Kamayurá uma cerimônia do aru'a ou Morcego, que se realiza no principio da estação chuvosa. Não houve oportunidade de a observarmos, nem lhe pudemos descobrir o simbolismo, mas parece relevante que homens e mulheres formem, nela, grupos de atores que se opõem, como se opunha o do Morcego àquele que lhe forneceu mulher. Como dos Kamayurá nenhuma tradição 
foi, até hoje, obtida quanto aos antepassados do Ancestral, isto poderia suscitar a idéia de que o sistema mítico-religioso xinguano forma uma totalidade só compreensível globalmente, por ocorrerem numa tribo elementos simbólicos só explicáveis por via de outros que, faltando nela, vão aparecer numa ou em várias das vizinhas. Coisa que se deveria atribuir à intensa aculturação intertribal que aí se verificou e verifica, e portanto à circulação informal de elementos míticos entre as aldeias (v. Laraia 1970: 119).

Em abono de uma ligação entre essa festa Bakairí e o Kwarïp, vem algo a cujo respeito o que sabemos é mínimo: num documentário cinematográfico de Jesco von Puttkamer entre os Mehináku, vê-se um grupo de pajés em torno de um Morcego vivo, sobre o qual sopram a fumaça de seus longos cigarros. Semelhante rito, se de rito se trata, não o vimos nos Kwarïp Kamayurá, ou Kalapálo, e isto deixa a questão aberta ao investigador.

Relativa à genealogia dos Gêmeos seria a dança da lagarta, que poderia corresponder à da minhoca ou evoi, efetuada, no ciclo do Kwarïp Kamayurá, no auge da estação das chuvas. Mas não é este o fato que nos levou a tal suposição. E sim o de que no mito Bororo de Bakororo e ltubore - cujas afinidades com a tradição Bakairí ressaltamos - a Mãe da Onça é uma larva ou lagarta (Albisetti e Venturelli 1969, 2: 188-191; Rondon 1948: 173-177; Lévi-Strauss 1964: 132; Baldus 1937: 175-176, 178-185; Colbachini 1942: 190-196). Portanto, não é impossível que, relacionandose o makanari à ascendencia masculina do Ancestral e por conseguinte dos Gêmeos, se relacione o imigo à sua linha feminina.

Há aqui, ainda, um outro ponto que aproxima a v. 322 à tradição Bororo. Os Gêmeos, à medida que multiplicam e localizam as tribos, obedecem a uma subdivisão geográfica que as cataloga em duas grandes classes, oriental e ocidental, devida aquela a Keri (Sol) e esta a Kame (Lua). Quer isto dizer que a principal personagem do mito é responsável pelo grupamcnto de leste, e a outra pelo de oeste. Exatamente o inverso é o que ocorre na mitologia Boraro, cabendo o ocidente a Bakororo e o oriente a Itubre, numa aparente contradição que, no entanto, não existe e se esclarece por algo que abordamos sucintamente, ao nos ocuparmos das conclusões históricas da comparação.

Keri e Kame são os vocábulos aruak para lua e sol, e tivoram seu significado invertido pelos Bakairí ao se dar o empréstimo. Na tradição aruak que por hipótese temos de admitir, o principal papel caberia ao Sol e o secundário à Lua, isto é, a Kame e Keri respectivamente, e não a Keri e Kame. Ao dar-se a permutação de posições, esta afetou seus papéis e a significação dos nomes, mas não a associação de cada nome a um ponto cardeal e a um grupo de tribos. Tal situação original hipotética poderia representar-se assim: 
papel principal : papel secundário :: Bakororo : Itubore :: Tschichi: Nuna :: Sol: Lua :: *Kame (aruak) : *Keri (aruak) :: Oeste : Leste

Semelhante oposição entre ocidentais e orientais não se encontra no resto das variantes xinguanas, e as tribos aparecem ou pelos esforços isolados dos Gêmeos, ou deles e do Ancestral em colaboração. Vago vestígio daquela dualidade de atuação estaria na v. 121 a, quando diz que "Yai (Lua) fez as tribos inimigas", implicando que Kwat (Sol) teria feito as amigas; mas, sendo esse um texto diminuto, e além disso discrepante de suas variantes tribais, nada se pode adiantar.

Substituindo, e equivalendo a este dualismo leste-oeste nas mitologias Bororo e Bakaíri, encontramos na Awetï um outro, que distingue índios mansos e bravos, xinguanos e não-xinguanos. Melhor prova não se desejaria da consciência que de sua coesão social e unidade cultural tem os índios do Alto Xingu, coesão e unidade essa que os opõem, como um todo, àqueles que social, cultural e geogràficamente lhe são marginais. A interação com os marginais fez-se sempre em termos de antagonismo e hostilidade muito superiores aos verificados entre os xinguanos. Por exemplo, nas relações com os Suyá a guerra alternava com a tendencia à sua integração no sistema de casamentos, cerimoniais e comércio que regula a comunicação pacífica das tribos especificamente xinguanas.

No sistema classificatório intertribal que apresentamos no Quadro 4 e que foi deduzido da variante 111, diversos critérios são sucessivamente aplicados. ${ }^{17}$ Em primeiro lugar vem o que considera a substância dos antepassados dos grupos que depois se definem com maior precisão. Das canas que servem para hastes de flecha vieram os índios, da de ubá os xingnanos, e de cambaiúva os que o não são, numa correspondencia real com os materiais que empreg-clm em suas armas. O segundo critério atémse ao comportamento observado nas relações intertribais, separando as duas Cabre, numa aparente contradição que, no entanto, não existe e sE esclarece por algo que abordamos sucintamente, ao nos ocuparmos das conclusões históricas da comparação.

Keri e Kame são os vocábulos aruak para lua e sol, e tiveram seu significado invertido pelos Bakairi ao se dar o empréstimo. Na tradição aruak que por hipótese temos de admitir, o principal papel caberia ao Sol e o secundário à Lua, isto é, a Kame e Keri respectivamente, e não a Keri e Kame. Ao dar-se a permutação de posições, esta afetou seus papéis e a significação dos nomes, mas não a associação de cada nome a um ponto

${ }^{17}$ Consideramos dois tipos de critérios: explícitos e implícitos. Estes, que o não enuncia diretamente, são exigidos por uma coerência interna, e figuram no Quadro 4 entre parênteses. 
cardeal e a um grupo de tribos. Tal situação original hipotética poderia representar-se assim:

papel principal : papel secundário :: Bakororo : Itubore ., Tschichi : Nuna :: Sol: Lua :: .Kame (aruak) : *Keri (aruak) :: Oeste : Leste

Semelhante oposição entre ocidentais e orientais não se encontra no resto das variantes xinguanas, e as tribos aparecem ou pelos esforços isolados dos Gêmeos, ou deles e do Ancestral em colaboração. Vago vestígio daquela dualidade de atuação estaria na v. 12:1 a, quando diz que "Yai (Lua) fez as tribos inimigas", implicando que Kwat (Sol) teria feito as amigas; mas, sendo esse um texto diminuto, e além disso discrepante de suas variantes tribais, nada se pode adiantar.

Substituindo, e equivalendo a este dualismo leste-oeste nas mitologias Bororo e Bakaíri, encontramos na Aweti um outro, que distingue índios mansos e bravos, xinguanos e não-xinguanos.

Melhor prova não se desejaria da consciência que de sua coesão social e unidade cultural tem os índios do Alto Xingu, coesão e unidade essa que os opõem, como um todo, àqueles que social, cultural e geogràficamente lhe são marginais. A interação com OS marginais fez-se sempre em termos de antagonismo e hostilidade muito superiores aos verificados entre os xinguanos. Por exemplo, nas relações com os Suyá a guerra alternava com a tendencia à Slla integração no sistema de casamentos, cerimoniais e comércio que regula a comunicação pacífica das tribos especificamente xinguanas.

No sistema classificatório intertribal que apresentamos no Quador $4 \mathrm{e}$ que foi deduzido da variante 111, diversos critérios são sucessivamente aplicados. ${ }^{17}$ Ern primeiro lugar vem o que considera a substância dos antepassados dos grupos que depois se definem com maior precisão. Das canas que servem para hastes de flecha vieram os índios, da de ubá os xinguanos, e de cambaiúva. os que o não são, numa. correspondencia real com os materiais que empregam em suas armas. O segundo critério atémse ao comportamento observado nas relações intertribais, separando as duas categorias de bravos e de mansos. A situação dúbia dos Txikão, que atacavam frequentemente até serem pacificados em 1964, reflete-se em estarem incluídos na classe dos bravos, tendo, ao mesmo tempo, flechas de ubá, que é um dos traços que os aparentam aos xinguanos, ao menos sob o ponto-de-vista destes; outro - de que não cuida o mito - é, por exemplo, a semelhança na construção das casas.

\footnotetext{
${ }^{17}$ Consideramos dois tipos de critérios: expllcitos e implicitos. Estes, que o não enuncia diretamente, são exigidos por uma coerência interna, e figuram no Quadro 4 entre parênteses.
} 
Há certa hesitação ao classificar o branco, que se constituiu em elemento perturbador de um sistema que lhe pré-existia, e esta hesitação é reforçada pela sobreposição de duas versões quanto à origem dos homens: uma, que, os faz derivar das matérias das armas, dá o branco como feito de madeira de coronha: a outra, como criado de "pedra". Esta na verdade é argila, escura a que serviu para o preto, tabatinga a. que se destinou ao branco. Isto evoca imediatamente a possibilidade de contaminação com crenças cristãs, sobretudo numa variante que equipara o Ancestral a Jesus; mas é difícil decidir, porque não é o único mito do gênero. Capistrano de Abreu obteve uma variante Bakairí (1938: 254-255), Schultz uma outra dos Waurá (1965-6: 38-41), e recolhemos terceira dos Kamayurá. De qualquer modo, a classificação dos civilizados de acordo com sua substância é simétrica à dos índios, pela introdução das subclasses dos negros e dos brancos. Quanto ao comportamento não se enquadram nas categorias anteriores, sendo explicitamente neutros.

Depois, este sistema classificatório abre-se, para incluir tantas sociedades tribais quantas forem necessárias. O Caraíba, postas de lado as diferenças de cor, é também uma "tribo" em pé de igualdade com as outras, pois aqui passa a vigorar um critério que considera, não a substância de que teriam sido feitos os homens, mas a cultura de que são portadores. Este critério cultural define cada grupo étnico por meio de uma série de elementos que, ao serem atribuídos, se tornam traços distintivos tribais. No esquema, como no texto, o número destes não é constante para cada um de seus termos, mas isto não tem importância fundamental, pois a análise do resto dos documentos e a experiência de campo mostraram-nos, juntamente com os dados dispersos pela bibliografia, que uns objetos tem mais relevância que outros como traços distintivos.

Dos relacionados na v. 111, são de ordem essencial, além do nome da tribo, a penela Waurá, o arco preto Kamayurá, e os colares dos grupos Karib. O feitiço aparece como característico dos Matipu, sem dúvida porque um dos feiticeiros xinguanos de maior fama é dessa aldeia, sendo conhecido também por sua habilidade na fabricação de colares. Preechendo a lista que se apresenta lacunosa, deve-se acrescentar que no passado Yawalapití e Mehináku foram ceramistas, que os Trumaí parece terem detido o monopólio dos machados de pedra, e que os Aweti teriam funcionado como "comerciantes", que faziam circular na área bens da civilização e outros, obtidos, aqueles, dos Bakairí ou dos brancos do Paranatinga e do Batovi (Oberg 1953: 17,42) ${ }^{18}$.

${ }^{18}$ Segundo Schaden (1965: 95-96), apoiado em Galvão e Saake, os Mehinaku também foram "comerciantes". Em ambos os casos, parece tratar-se de uma mudança induzida pela presença da civilização. 
Alcançamos assim o problema, pouco estudado em profundidade, das relações comerciais das tribos xinguanas, que se apóiam na especialização intertribal de determinadas manufaturas. Ora, tudo indica que esta se mantém artificialmente, uma vez que o grau de progresso tecnológico dos xinguanos é uniforme, e que nas várias tribos se encontram individuos capazes de fabricar os objetos em que outras se especializaram: só que não o fazem, continuando a consegui-los por troca. Oportunamente, Egon Shaden apontou (1965: 83-85) a função integradora desse comércio e especialização, ao criar fictícios laços de interdependencia econômica entre os grupos locais, e pudemos verificar que os itens objeto de especialização coincidem com os que servem de traços distintivos essenciais. Descobriu Carmen Junqueira (1966: 10), nos Kamayurá, três niveis de valor de troca, sendo o superior ocupado "pelos objetos "caros" ou nobres - as grandes panelas Waurá, os colares de caramujo, os colares de unha de onça, o arco de madeira preta, a canoa, etc.": isto é, precisamente os que desempenham no mito as funções de traços distintivos, com exceção da canoa.

Se este sistema formalizado de circulação de bens econômicos gera forças de integração social ao nivel intertribal, compará-lo-iamos ao sistema de circulação de mulheres que, àquele mesmo nivel, na área também existe. Se assim for e podendo-se generalizar dizendo que todo sistema de troca de mulheres é um sistema de comunicação social (Lévi-Strauss 1949), poder-se-ia dizer também que o comércio formal do moitará é um sistema de comunicação intertribal, em que as manufaturas trocadas são os elementos portadores de significação. Partindo do principio de que, com toda a probabilidade, os tais objetos "caros" são os de mais dificil aquisição e portanto os menos frequentes nas trocas, levantariamos a hipótese de que tenham sido selecionados como traços distintivos para o mito, exatamente por causa dessa baixa frequência, pois esta é sempre inversamente proporcional à quantidade de informeação contida num signo. Isto é, sendo menos frequente seria mais informativo o manufacto especializado, e passaria a significar a tribo por ele responsável. Daí a posição em que o vemos, nesse outro sistema de comunicação que é a mitologia. Mas esta é uma hipótese carente ainda de verificação, e, se possivel, de um tratamento estatístico.

Voltando ao esquema Awetï, notamos que as duas grandes categorias de brancos e de índios se diferenciam culturalmente pela aceitação ou recusa da pinga, do leite e da carabina. Desta distância cultural emergirá uma distância geográfica, pois o herói afasta o Caraiba de Murena, do lugar que mais carregado está da realidade paradigmática indígena criada 
pelo mito. A partir daqui, a narrativa entra decididamente por um terreno que já não é mítico, mas histórico-lendário: a chegada dos brancos ao Rio de Janeiro, seus conflitos com os índios, e a fuga destes para a região do Alto Xingu. Isto é de especial interesse, pois evidencia como esta última parte do mito, muito mais do que aquela que chamamos nuclear, está aberta ao devir histórico e é capaz de incorporar, "cosmizando-os", os elementos novos de uma cambiante realidade sócio-cultural.

Das outras variantes, comentaremos um ou outro ponto capaz de complementar o que se disse. Av. 121 conta que, antes de mandar os antepassados para suas aldeias, o Ancestral lhes determinou a rotina diária: banho de manhã, assobiando, relações sexuais à noite e trabalho durante o dia. Os textos Waurá, por seu lado, dão especial atenção ao pormenor cerimonial, com a apresentação dos chefes e sua condução aos banquinhos associados ao status que 'tem. Neles é notável, também, o lugar ocupado pela nominação das tribos, pois o nome é um de seus traços distintivos mais importantes, e nisso tudo, ao contrário do que acontece nas outras tradições, os Gêmeos são também ajudados pela Onça. Pertence à v. 223 a história do chefe que ficou sòzinho e que foi transformado em perigoso "boneco" de pedra; esta crença em vestígios físicos do passado mítico no Murena ocorre também entre os Kamayurá, sob a forma de um kwarïp (o da primeira dessas festas) que ali estaria escondido. Ignoramos qual a base disto, mas a experiência demonstra que o mito xinguano seleciona sempre, para construir-se, aspectos concretos da realidade ambiente.

As duas versões da criação das tribos que recolheu Quain entre os Trumai testemunham o conflito existente no seio de sua cultura, traumatizada também pela precária acomodação nas relações intertribais. O prestígio dessa sociedade foi sempre fraco, seus contacto difíceis e pontilhados de hostilidades, superadas, no entanto, pelas doenças como causa de sua quase extinção.

\section{0 - KWARIP DA MÃE DO SOL E DA LUA}

Nesta última parte do mito, as tradições Waurá e Kamayurá fazem-se como que um contraponto, em que à primeira cabe a descrição dos procedimentos cerimoniais e à segunda a das peripércias desse primeiro Kwarïp comemorativo, que, como é próprio, se teria realizado no fim da estação seca. Isto aconteceu não na aldeia do Murena para onde os levara o Ancestral, mas noutra, Kuluene acima, provavelmente aquela em que morrera a 
mãe dos Gêmeos, pois qualquer Kwarïp deve ser festejado onde se acha sepultada a pessoa que se honra. Este é a reencenação do ato que transforma as mulheres de pau, e sua estrutura sintetiza, nos dois dias que dura, toda a trama de relações intra e intergrupais prefiguradas desde o encontro do Ancestral com a Onça.

A v. 225 narra, como o observamos no campo, o ritual desse clímax do ciclo da festa dos mortos, que atinge, então um nível de participação intertribal, uma vez que os preparativos anteriores se limitam ao âmbito da tribo promotora. O ciclo alcança aquele nível no momento em que se enviam os pareat, que, como mensageiros, estão revestidos de prerrogativas especiais; sua visita à aldeia convidada é altamente formal, cercada de cuidados e seguida de recomendações sobre o comportamento pacífico que ambos os grupos deverão manter. Isto porque no decorrer da festa a tensão emocional cresce a um grau de animosidade muito superior ao normal, que é, intencionalmente, revigorado e exacerbado por bravatas como a do Poraquê, e por comentários depreciativos que entre si fazem, quanto às outras, os homens de cada tribo.

Seria possível distinguir quatro fases no Kwarïp e nos dias que imediatamente o antecedem. Na primeira, o distanciamento, geográfico e social, diminui, com um correlativo aumento das tendencias agressivas, que chegam ao auge quando, à noite, os visitantes invadem, gritando, o terreiro dos visitados, num autêntico charivari. É a isto que se refere a v. 225, ao dizer que "na aldeia só de noite se diz besteira", isto é, se expressam verbalmente as tensões acumuladas. Na segunda, do dia seguinte, há a catarse na competição de luta corporal, que logo cede lugar à distribuição de castanha de piqui e jarreteiras, feita por uma jovem púbere que vai sair de reclusão, numa terceira fase que interpretetados como simbólica oferta de aliança, pela troca de mulheres, aos grupos visitantes. Por fim, na quarta fase, comem e dançam num clima de distensão, sendo que nas danças participam as mulheres da aldeia e os homens de fora ${ }^{19}$, numa implícita aceitação da aliança oferecida. Com isto em mente, poder-se-ia estabelecer o seguinte quadro de equivalências simbólicas entre o mito e o rito:

\section{Rito}

Visitantes invadem o terreiro

Participantes lutam entre si

Moça oferece castanhas e jarreteiras

Visitantes dançam com mulheres da aldeia

\footnotetext{
${ }^{19}$ Mulheres das tribos visitantes também podem participar da dança.
} 


\section{Mito}

Ancestral encontra a Onça

Onça disputa com Ancestral

Ancestral oferece mulheres à Onça

Onça aceita a oferta

Na festa, há um nítido contraste no comportamentto, ativo dos homens, e, geralmente, passivo das mulheres, que quase sempre permanecem sentadas, assistindo, durante as manifestações mais marcadas de antagonismo. Isto corresponde à dualidade de atitudes e forças em jogo nas relações intertribais, em que o etnocentrismo agressivo é coibido e ritualmente canalizado, resultando num padrão de interação pacifica porém tensa, sobretudo quando essa interação se dá, não entre indivíduos isolados, mas entre tribos incorporadas. Pode-se suspeitar que a ordem de marcha, quando se dirigem para o Kwarïp e quando dele se retiram, seja um reflexo desse padrão; na vinda, os chefes e as mulheres marcham adiante, e são os primeiros a entrar e os últimos a sair da aldeia, como que em penhor e garantia de que a agressividade dos homens não transbordará dos limites de sua manifestação ritualizada. Os quais, diga-se de passagem, são por vezes individualmente rompidos.

No mito os Gêmeos tem o papel de "donos da festa", isto é, de responsáveis por sua organização e direção, e, por causa deste status cerimonial temporário adquirido, é-lhes vedado participar da luta. Porém o Sol infringe as normas, o que parcialmente se justifica pelo fato de ser a Lua a presidir ao cerimonial, e não ele: mas nem por isto deixou de haver quebra das regras socialmente aprovadas, sem que nossos informantes pudessem explicar a razão. Acabada a luta, a v. 225 conta-nos a confraternização geral em que se dá comida aos visitantes. Destes, os pareat recebem presentes que pertencem ao sistema de prestações e contraprestações de bens e serviços cerimoniais, em vigor desde que se começa a organizar o ciclo do Kwarïp, primeiro ao nível intratribal, depois ao intertribal, num alargamento progressivo das relações sociais promovidas pela festa. Acabada, os visitantes despedem-se e partem como o fizeram os peixes, mas, se moram longe, podem pernoitar na casa de seus hospedeiros.

Isto contrasta nitidamente com o que acontece na noite da chegada, em que acampam fora da aldeia e marcam bem a distância e a animosidade existentes: esta manifesta-se em verdadeira guerra mágica, em que as fórmulas kevere ${ }^{20}$ são empregadas para provocar a derrota dos adversários

\footnotetext{
${ }^{20}$ As fórmulas kevere não têm a malignidade do feitiço strictu sensu (muãng), que provoca doença e morte. Um dos kevere mais usados é o "canto de praia", para tornar o chão da aldeia pouco firme sob os pés do lutador, como a areia das praias.
} 
no dia seguinte. O trânsito entre os campos e a aldeia é restrito, e recaem sobre os pareat todas as providencias necessárias, pois outras pessoas poderiam ser contaminadas pela magia adversa e servir-lhe de veículo até aos lutadores. Ao kevere de uns contrapõe-se o dos outros, que se destina a "mandar de volta" a agressão mágica. Agressão, também, é a sedução das filhas do Veado pelos peixes Tukunarei e Yakunã, cuja filiação a grupos distintos está patente: eles vem de longe, elas não; eles são peixes e aquáticos, elas mamíferos e terrestres. Observamos que a sedução pode funcionar, entre facções políticas ou grupos tribais, como meio de agredir e lesar o prestígio de opositores; numa crise de poder na aldeia Kamayurá, dizia-se que o líder "rebelde" tinha conquistado a mulher do irmão do líder "legítimo", e que o marido ofendido revidara tendo uma aventura com a do rival. Outro exemplo se deu com os Txikão. Estes até 1964 foram inimigos dos xinguanos, atacando-os frequentemente, e depois de pacificados passaram a residir próximos e a frequentar os Kamayurá. Quando isto acontece, ouvem-se comentários de profundo etnocentrismo, e os homens Kamayurá não poupam esforços para desviar a atenção dos maridos e ter acesso às mulheres; no caso que registamos a escolhida, por medo, recusou-se. Assim, acampar afastados previne possíveis incidentes, até que a hostilidade se expresse e esgote na luta, e de lugar a reafirmação da solidariedade dos xinguanos. Que não é absoluta: há sempre o perigo do Karikari arrastar alguma mulher para seu ambiente... Apesar disso, no fim da festa já podem os hóspedes pernoitar na casa do respectivo pareat.

Aconselhados pelo Ancestral a fazer Kwarïp para sua mãe, os Gêmeos mandam chamar os Peixes, que ao irem para casa o Sol vão balizando o caminho com vestígios - tinta, carvão, sangue - que recordam o acontecido e explicam pormenores da paisagem.

Passaremos por alto estes aspectos etiológicos do mito, para acentuar apenas que essas marcas são novos pontos de referência, no plano geográfico, da organização do cosmos xinguano. Também só ràpidamente tocaremos no filho do campeão Karatuaruwiyap, que de começo é só um ovo, mas depois participa da ação: é possível que haja uma equivalência entre o filho do campeão que desabrocha para competir, e os rapazes que, em fase de iniciação pubertária, são treinados e estimulados pelos parentes a enfrentar os melhores lutadores. Haveria talvez uma associação entre o ovo de que sai o rapaz e a cabaça em que foram guardados os Gêmeos, por sua vez equivalente ao recinto de reclusão pubertária, mas faltam-nos dados capazes de fundamentar a hipótese.

Os Peixes estão bem definidos, como grupo, por suas caracteirísticas físicas e seus hábitos aquáticos. Já o Katsinĩ que encontram pescando é 
por si um ser ambíguo na aparência e nas ações. Aquela é como a dos sapos cantadores, habitantes dos terrenos pantanosos e intermediários entre o terrestre e o aquático. Comportando-se como terrestre ao pescar, Katsinĩ comporta-se como se o não fosse, ao acompanhar os peixes em seu ambiente, "que é como o seco". Mas ao fazê-lo permanece afastado nos pernoites, pelo antagonismo que apesar de tudo os opõe e que se traduz na pesca e na inimizade que lhe votam as piranhas. A qual não obsta à sua incorporação e comparecimento à festa no grupo dos peixes, a que pertencem seus filhos; e será os peixes que acabará protegendo contra seus inimigos. Os filhos, aliás, gerara-os enfiando o dedo no ânus da arraia, numa nova faceta da ambiguidade de Katsinĩ, que, sapo e pescador, tem filhos de peixe. Não se pode deixar de notar também que a ambivalência de atitudes entre ele e os peixes ocorre entre personagens ligados por uma forma de comunicação sexual, (no caso indireta), como o Ancestral e a Onça.

A tribo dos peixes opõe-se à dos mamiferos terrestres como categoria classificatória perfeitamente diferenciada, num pé de igualdade com as categorias (étnicas) a que pertencem as tribos que participam de qualquer Kwarïp. E este, por sua vez, manifesta ritualmente o mesmo sistema de oposições intergrupais evidenciado pelo mito. É por isto que a tradição Kamayurá e a Waurá podem ser tomadas em conjunto, ou isoladamente, sem afetar sua compreensão final: porque uma fornece, sob a forma de uma série de acontecimentos míticos, a mesma informação que a outra transmite pela descrição pormenorizada do cerimonial. Isto é, pela descrição verbal de atos que são de uma linguagem ritual, dotada de um código que lhe é próprio e capaz de enunciar, sob outra forma, um conteúdo fundamentalmente idêntico. Foi-nos impossível estabelecer uma relação direta, em que uma tribo personificasse os peixes e outra os mamíferos na representação do drama mítico; nem isso é absolutamente necessário, parque a correspondencia de papéis deriva da de posições na estrutura de relações intertribais. Deve-se ainda notar que os Gêmeos, embora dotados de poderes extraordinários, tem aspecto e comportamento humanos e são classificados com os mamíferos e não com os peixes. E assim, a cachoeira que deixaram para retardar e prender os últimos explica-se, também, em termos daquele antagonismo de que falamos; ao mesmo tempo, isto leva a admitir que, no plano ecológico, Katsinĩ e os Gêmeos se aproximam como captores de peixes e potenciais competidores.

Esse plano adquire particular importância nesta parte do texto. Noutros mitos, xinguanos ou não, os Gêmeos são frequentemente adversários das ariranhas - num papel muito semelhante ao desempenhado, neste, 
por Katsinĩ. Mas no cerimonial, quer o que observamos, quer o descrito pela v. 225, nada há que se possa equiparar à súbita intrusão das ariranhas nas v. 126b e 127, que, aliás, nos fez hesitar quanto à devida interpretação. Nessa intrusão as ariranhas vem em busca do peixe, que Katsinĩ protege na "casa das flautas"; esta, na mitologia Kamayurá, é um lugar associado à água e a sobrenaturais aquáticos. Na sua condição de mamíferos anfíbios e carnívoros, as ariranhas participam de uma ambiguidade como a de Katsinĩ, e concomitantemente, competem com ele pela posse do peixe. Quando Katsinï o salva, salva-o provavelmente para si, o que lhe dá uma ambivalência de atitudes e comportamento, pois o pesca e defende. É também por causa de peixe que Gêmeos e ariranhas estabelecem conflito noutros textos, e, ao fazerem-no, aqueles colocam-se na posição própria de homens, que é também a de Katsinĩ, quando resguarda os peixes na casinha ritualmente reservada a seus espíritos tutelares. Consideradas na cadeia alimentar, as ariranhas, como predadores fluviais, tem um pôsto preeminente que as faz potenciais competidores do índio xinguano, e talvez o mesmo se pudesse dizer do conflito das Onças - predadores terrestres - com os homens, que são também caçadores.

Poderia ficar a hipótese, algo arriscada, de que as tribos que competem no Kwarïp se vejam entre si como propensas à competição ecológica, sobretudo nas áreas de pesca. Como no caso de Katsinĩ e dos Gêmeos, indiretamente evidenciado por via das ariranhas.

Mantendo-nos ainda no mesmo plano, temos agora a considerar a recomendação do Ancestral aos Gêmeos: o Kwarïp, daí em diante, será comemorado periodicameme em época fixa do ano, entre fins de agosto e começos de outubro. Repete-se ciclicamente, portanto, a festa naqueles meses que marcam a transição da estação seca à chuvosa, e o recomeço do ciclo ecológico do sistema adaptativo xinguano. Recorde-se que é nesses meses que a aranha Bakairí, capaz de renovar-se trocando de pele, ascende ao céu deixando um fio atrás de si.

É condição econômica básica para a realização do Kwarïp a abundância de peixe, que por sua vez depende diretamente do nível dos rios. Quanto mais baixas as águas, maior a concentração do pescado e mais efetiva a pesca com veneno, única capaz de produzir grandes quantidades com técnicas tradicionais. Os entendidos mantém os cursos de água em observação, e disso depende a palavra final para a festa. Com as chuvas o volume dos rios aumenta até transbordarem, e o peixe dispersa-se e escasseia. Daí que não pareça fortuito que sejam eles os que vem para o Kwarïp, e que nele tão importante papel desempenhem. Paulatinamente, no mito, como no mundo ambiente, o peixe aumenta e alcança o apogeu no momento da festa e do trânsito entre estações. E à medida que chove ele vai- 
se pelas águas, como, acabado o Kwarïp, foi rio abaixo até depois do Diauarum. Não há contradição senão aparente entre a tradição Waurá e a Kamayurá, mas simples diferença de foco. Fixada no procedimento cerimonial, a v. 225 toma como referente o ciclo ecológico e mostra-nos o peixe partindo, enquanto as v. $126 \mathrm{~b}$ e 127 mantém sua preocupação etiológica e assinalam mais um marco da geografia xinguana.

A última recomendação do Ancestral é de que, no fim da festa, atirem o kwarïp no lago. Chegamos noutro estudo à conclusão de que seu simbolismo de recriação do cosmos era o princípio responsável pela realização do Kwarïp na mudança de estação, e que entre isso e as lágrimas choradas na ocasião, haveria íntima ligação simbólica. Também sob este prisma se deve encarar o ato que encerra o cerimonial, mergulhando nas águas os troncos que representam os mortos, pois Lévi-Strauss (1966: 182-191) demonstrou cabalmente a relação entre o mito da "noiva de pau", o choro, as "águas externas" e o surgimento da estação chuvosa.

Não pára aqui, entretanto, o simbolismo desta ação ritual, mas para penetrá-lo teremos, à míngua de elementos xinguanos, de os procurar, outra vez, na cultura Bororo. No Alto Xingu conhecem-se quatro tipos de sepultamento, que dependem do status e tem a característica comum de serem enterramentos primários feitos no centro da aldeia, em que o morto fica olhando para leste. Os kwarïp, que se identificam expressa e individualmente a cada um dos falecidos, elevam-se, também, virados para que vejam o sol nascer, e só eles são atirados à água.

Esta reaparece numa das três modalidades que assumiu, historicamente, o funeral Bororo. Neste, o sepultamento definitivo é secundário. Numa primeira fase o defunto é colocado em cova rasa, coberto, e regado até que se decomponha, sendo depois exumado, deacarnado, e, mediante elaborado cerimonial, depositado em local definitivo. Na aldeia de Arigáo Boróro, as cestas funerárias eram postas em inumeratórios coletivos; no cêrro de Cibaé E-iári encontraram-se as cestas em cavernas; e o costume atual é de submergi-las num lago ou córrego remansoso, atadas a uma vara que se espeta no fundo (Albisetti e Venturelli 1962, 1:112). Este último seria de adoção recente, mas é pouco de crer que fosse aceite sem que algo, na ideologia tribal, predispusesse à aceitação e tornasse condizente a nova foram de dispor dos mortos com o sistema simbológico existente. É por isso que não achamos aventurado propor uma equivalência entre as covas, as grutas e as águas que serviram de sepultura. E se isto for aceitável, vamos encontrar-nos de novo ante a reclusão ritual como subtração temporária ao mundo dos vivos, e portanto morte simbólica: numa variante Bororo do mito que analisamos, os Gêmeos, retirados pwstumamente do ventre da mãe, são resguardados na caverna Marabarito (Baldus 1937: 
178-185). Noutras variantes, Bororo também, em vez da caverna temos a cabaça (Rondon 1948: J73-177), ou a cabaça Marabari (Colbachini 1942: 190-196). Se não bastasse sua função, o nome da segunda cabaça viria apontar-nos para a caverna da primeira variante. Estabeleceríamos assim uma cadeia bororo de equivalências, cocabaça-mala-mïrïtsi-água. Sendo o kwarïp identificado ao morto, não é despropositado incluir nessa série a cova, o que a aproximaria ainda mais da dos Bororo. Desta maneira, ao ser pôsto o kwarïp em "reclusão" subaquática, abre-se para aquele que representa a perspectiva de um novo status: agora o definitivo de morto, e habitante da aldeia das almas no céu. Restaura-se assim a comunicação rompida pelo afastamemo do céu e da terra, como a restura, na mesma época do ano, a aranha Bakaíri. Nakoeri subiu ao céu por um fio de algodão, ela deixa um fio atrás de si, e para aqueles índios é também por uma linha de algodão que as almas sobem a sua morada (Abreu 1938: 253). É também nesta festa que os enlutados perdem sua condição e podem reassumir uma vida livre de restrições rituais.

Marca portamo o Kwarïp o momento crucial em que as coordenadas dos ciclos ecológicos e vital se cruzam, inclusive sob um aspecto biológico. Pela sua recriação simbólica se revitaliza o cosmos xinguano, e a "reclusão" dos troncos, por seu caráter, é fim e início, regresso às origens e promessa de nova ou renovada realidade: e assim seu ato final é síntese de todo o simbolismo da festa. Veríamos nele, aliás, o traço de união entre os mitos de origens de modelo estritamente vegetal, e os mitos de emergência que encontramos em tribos mais ou menos vizinhas, por exemplo Paresí e Mundurukú. Basta retomar as séries de equivalências que ficaram atrás, retendo delas apenas os termos essenciais, para que a idéia se torne legítima:

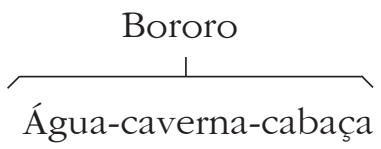

Reduzindo ainda mais, teríamos ÁGUA-CAVERNA, e é de cavernas, grutas, ou buracos no chão, que nesse mitos emerge a humanidade.

\section{0 - NOMINAÇÃO DOS GÊMEOS}

Advertimos oportunamente que esta passagem do arque-mito foi reconstituída com fragmentos destacados das v. 125, 126, 127 e 311, orde- 
nados por comparação com o texto resumido 129, que, correndo paralelo àquelas variantes, se preocupa apenas das sucessivas nominações dos Gêmeos. A principio eram por completo distituídos de nome, como o são os recém-nascidos; e à medida que vão avançando da infância à adolescência e desta à idade adulta, trocam uns nomes pelos outros. A nominação definitiva deu-se pouco antes do Kwarïp, e se esta não fosse uma comparação à parte, o episódio deveria inserir-se entre o ataque à aldeia das Onças e a classificação das tribos.

Nesta ocasião, os Gêmeos já estão definidos por uma série de predicados que adquiriram ou lhes foram atribuídos, o último dos quais é o nome. Possuindo-o, e transitando ao status de adulto, eles realizam o Kwarïp - ritual de passagem por excelência. Com isto os Gêmeos estão investidos de todos seus traços distintivos, e encerram um ciclo de suas vidas: o da infância, que é também o da "infância" do mundo, durante o qual eles se organizam, organizando-o, completando-se o todo em seus caracteres essenciais.

O primeiro dos nomes, Tïre' $\tilde{m} m$, pertenceria indistintamente aos dois Gêmeos, e não levanta problemas porque deriva diretamente da sorte de sua mãe. Na nominação seguinte, há ligeira discrepância entre a v. 127 e 128, pois num caso é o Tatu e no outro a Raposa que os chama Tape akanã e Tape iyaok-Tape iyau. Faltando-nos dados das outras variantes, inclinamo-nos a aceitar a versão da v. 127, visto ser, o informante, melhor conhecedor que o outro. Na v. 129, parece haver confusão entre o papel do Tatu e o da Raposa, personagem central do mito do roubo do fogo. Mas a questão que emerge não reside aqui, mas nos próprios nomes dos Gêmeos, já agora diferenciados.

Na mitologia Kamauyrá e nas crenças associadas, nada encontramos capaz de explicar o significado mítico desses nomes, que se traduzem como "caminho que vai para a esquerda" e "ziguezague do caminho". No entanto, talvez algo se possa conseguir recorrendo às variantes Tupi, cuja afinidade com as Bororo e xinguanas em tempo assinalamos. Quando as mulheres se dirigem à casa da Onça e são sucessivamente enganadas e possuídas, acabam por separar-se numa encruzilhada (v. 311), indo cada qual por sua trilha. Uma vai ter à Onça, mas a outra erra e junta-se ao Lobo, que nessa variante equivale ao Awaratsing Kamayurá. Nada mais nos diz o texto Kalapálo, mas, por sua posição no mito, este Lobo corresponde ao Sariguê dos Tupinambá e de outros Tupi (Métraus 1928), que engravida a mulher e é pai de um dos meninos, pois o outro é filho do herói cultural. Na tradição xinguana apenas a v. 121 fala de relações sexuais do Ancestral com as mulheres que fez, o que resultaria de uma persis- 
tência Tupi e de uma incompleta adoção da forma local do mito; no restante da tradição, os Gêmeos não derivam de dois atos sexuais independentes, mas da cópula com a Onça, ou do engolimento de ossos humanos (v. 322a); sendo que por vezes se ignora como a fecundação se deu (v. 411).

Assim, veríamos nas relações do Ancestral com as mulheres de pau (v. 121), no erro cometido na encruzilhada (v. 311), e nos dois nomes que discutimos (v. 127, 129), o eco daquela concepção do par em duas etapas: os vocábulos Tape akanã e Tape iyaok-Tape iyau seriam alusão às trilhas divergentes, que levavam às moradas dos dois sucessivos maridos de uma das moças. A falta de dados impede demonstrar a hipótese, porque a v. 311 não explicita se a mulher que pariu os Gêmeos foi a mesma que coabitou com o Lobo*.

Prosseguindo a busca da própria identidade enquanto organizam o mundo em seu redor, os Gêmeos acabam por encontrar - segundo a v. 126 já em Murená - o grilo Kwarayumiá ou o gafanhoto Tucura, que lhes pergunta como se chamam e recebe por resposta os dois nomes de que acabamos de tratar, ou um outro, de que não temos tradução: Tsaukuma. Não satisfeito, o Kamarayumia ou Tucura nomina-os novamente: Kwat e Yaï nos textos Kamayurá, Riti e Uné no Kalapálo.

Kwat e Yaï, Riti e Uné, Sol e Lua são uma e mesma coisa, e aqui entra um pormenor importante. O Kwarayumiá diz aos Gêmeos, literalmente:

"Eu tenho meu nome, é bom para você. Quer ver? Seu nome agora, Kwat. Seu irmão chama Yaï." Coisa semelhante ocorre quando o Tucura dá aos meninos o nome que é seu: Rititaurinbe. Tanto no termo Kamayurá quanto no Kalapálo há a possibilidade de isolar uma forma constituída pelas sílabas iniciais, que, por coincidencia ou não, correspondem ao morfema que significa sol nas respectivas línguas: Kwarayumia e Rititaurinhe. O fonema /r/ da forma Kamayurá não obsta, pois em posição

\footnotetext{
* Estando em provas este estudo, veio à luz excelente coletânea de mitos xinguanos (VILLAS BOAS, Orlando, \& VILLAS BOAS, Cláudio. Xingu: os índios, seus mitos. Rio de Janeiro. Zahar Editores. 1970), contendo 2 variantes da tradição Kamayurá (pp. 55-57 e 57-68), e uma variante Kuikúro (pp. 69-83). As Kamayurá seguem de perto a v. 127. A Kuikúro, pertence à mesma tradição dav. 311 (Kalapálo), o que se explica pelas afinidades entre os dois grupos; e esclarece que os Gêmeos foram gerados por dois pais (lobo e onça), em sucessivas etapas: "Combinaram seguir cada uma por um caminho. Uma pelo caminho da onça, a outra pelo caminho do lobo.... A mais velha foi sair na casa do lobo e foi por ele agarrada.... A mais moça foi sair na casa da onça.... A mulher já estava grávida do lobo.... Mais tarde essa mesma mulher ficou grávida da Onça. A outra não engravidava” (pp. 74-75).

A pesquisa foi subsidada pelo Smithsonian Institution-Wenner Gren Urgent Anthropology Program, e por doação de D. Mariana AIvim, ao Centro Brasileiro de Estudos Indígenas, contando também com o apoio de campo do Parque Indígena do Xingu.
} 
intervocálica /t/ $/>/ \mathrm{r} /$. Mais problemático seria descobrir Yaï e Uné no resto do nome do gafanhoto, e sem nenhum valor positivo: por isso nem o tentaremos. Mas há que levar em conta que nos mitos e ritual aparecem frequentemente vestígios de estágios arcaicos da língua, de dialetos, e de deturpações oriundas das trocas entre grupos que, sujeitos a profunda aculturação intertribal, provem dos mais diversos troncos linguísticos.

Resta dizer que existiu antigamente nas casas de flautas um grande trocano, que em Kamayurá se denominava Warayumia e pertencia aos cerimoniais das flautas e danças de máscaras. Estas foram iniciadas pelos Gêmeos, qae fabricaram as máscaras e o tambor, quando, para criar os rios, foram roubar a água, guardada num Tapwĩ ou rancho das flautas. Esse tambor era "de mama' ẽ", espíritos tutelares, mas nenhuma aproximação descobrimos entre sua designação e a do grilo Kwarayumia, apesar da semelhança, do ruído que produzem e das relações do trocano com rituais secretos masculinos.

\section{CONCLUSÃO}

Em síntese, vemos no Mito de Origens xinguano um sistema classificatório primitivo que organiza e estrutura uma ordem culturalmente condicionada, que se instaura, progressiva, a partir de uma realidade primordial indiferenciada e caótica. Processando-se geneticamente, essa classificação e estruturação apresenta-se formalmente como um mito de passagem, cujo ponto final é a descrição de um rito do mesmo tipo. Este, reencenando o ato original, fecha um ciclo e abre outro, sob uma multiplicidade de aspectos que são climáticos, biológicos, econômicos, ecológicos enfim, mas também sociológicos, religiosos, espaciais e temporais. Porque ao reatualizar-se o mito no rito, o lugar e o tempo da festa equiparam-se e portanto tornam-se no lugar e tempo originais e sagrados, radicalmente diferentes dos hodiernos e profanos. Há uma reconcentração do tempo e do espaço no Centro que é Murena, ou melhor, que é aldeia onde se representa o drama de Murena: o tempo profano e histórico se torna intemporal e sagrado pela participação e fusão rituais no paradigma mítico; para o Centro confluem as tribos e os peixes, num simbólico anular do espaço que a ampliação da terra criou; e a rompida comunicação com o céu se restabelece, como antes de que ele e a terra se separassem. E será deste Centro que se espalhará, novamente, a ordem de um Cosmo recriado.

Funcionalmente, ao comemorar a transformação inicial e iniciática, o Kwarïp gera forças potentes de integração social, reforça a consciência 
que os índios de seu mundo tem, e sua própria auto-consciência como membros de unidades sociais de nível cada vez mais elevado e abrangente, que se estruturam em pares de oposições: consanguíneos $\mathrm{X}$ afins, grupo co-residencial $\mathrm{X}$ grupo co-residencial, tribo $\mathrm{X}$ tribo, xinguanos $\mathrm{X}$ nãoxinguanos, índios X não-índios. De todas, a mais aparente pelo vigor de sua manifestação cerimonial é a que existe entre as tribos xinguanas, e isto dá-se pela necessidade de manterem a identidade étnica, numa profunda situação aculturativa e de interdependencia social. Mas, celebrando juntos a comum origem, comungam de uma unidade mais ampla, que as reúne em uma sociedade intertribal composta de segmentos linguística e politicamente autônomos.

Se o Mito de Origens funciona nesses termos e revela um mundo e uma sociedade ao nível do consciente indígena, encarado objetivamente por um observador externo mostra-lhe também uma realidade social perfeitamente delimitada. Não apenas pelo esquema entre outros, de classificação étnica que oferece: mas pelo fato de, construindo-se com unidades mínimas recorrentes noutras tradições, se constituir num todo estruturado e único, que, partilhado pela totalidade de suas tribos, define uma área cultural. 


\section{BIBLIOGRAFIA}

ABREU, João Capistrano de. Os Bacaeris. In: Ensaios e Estudos, $2^{\mathrm{a}}$ ed.Rio de Janeiro, Ed. da Soc. Capistrano de Abreu, 1938. p. 217-274.

AGOSTINHO, Pedro. Kwarip, festa dos mortos. Indios Kamayurá, Alto Xingú. Brasília, Universidade de Brasília, 1966. (Tese de Mestrado, dat.).

ALBISETTI, Cesar \& VENTURELLI, Ângelo, Jayme. Enciclopédia Bororo. Mato Grosso, Mato Grosso, Mus. Reg. D. Bosco, 1962-1969. 2v.

BALDUS, Herbert. Ensaios de Etinologia Brasileira, São Paulo, s. ed., 1937. (Brasiliana, série 5a da B.P.B.).

CARNEIRO, R.L.\& DOLE, G. E. La Cultura de los Indios Kuikuros del Brasil Central. Buenos Aires, s. ed., 1956-57. v. 8 parte segunda. Separata do Arquivo para las Ciências del Hombre. p. 169-202

CARVAlHO, José Cândido de M. Relações entre os índios do Alto Xingú e a fauna regional. Rio de Janeiro, Mus. Nac., 1951. (Publ. Avul.no 7).

COLBACHINI, P. Antônio \& ALBISETTI, P. Cesar. Os Bororós Orientais. Orarimugudogue do Planalto Central de Mato Grosso. São Paulo, C. Ed. Nac., 1942 (Brasiliana Gde. Formato v. 4).

CUNHA, Aires Câmara. Entre os índios do Xingú. São Paulo, Livr. Exposição do Livro, 1960.

DOLE, Gertrude E. ownership and Exchange among the Kuikúro Indians of Matto Grosso. Separata da Rev. Mus. Apul. São Paulo, 1956/8 N.S. v. 10. 
JUNQUEIRA, Carmen. A circulação de bens na sociedade Kamayurá.São Paulo, s. ed. 1966. p. mimeo.

LARAIA, Roque de Barros. O Sol e a lua na mitologia xinguana. In: LEVI-

STRAUSS ET alii. Mito e linguagem social. Rio de Janeiro, Ed. Tempo Brasileiro, 1970 .

LEVI-STRAUSS, Claude. Les Strutures élémentaires de La parente. Paris, P.U.F., 1949. Anthropologie structurale, Paris, Plon, 1958 Le Cru et le cuit. Paris. Plon, 1964 , Du Miel aux cendres. Paris, Plon, 1966.

METRAUX, Alfred. La Réligion des Tupinambas et ses rapports avec celle des autres tribus Tupi-Guarani. Paris, Ernest Leroux, 1928.

MURPHY, Robert \& QUAIN, Buell. The Trumai Indians of Central Brazil. Locust Valley, New Locust Valley, New York, J. J. Augustin Publ., 1955. (Mon. of the am. Ethnological Soc. v. 24)

NIMUENDAJU, Curt. "Tribes of the lower and middle Xingu River". In:

Handbook of South American Indians. Washington, Bull. B. A. Ethnology, 1948. v.3, p. 213-243.

OBERG, Kalervo. Indian tribes of Northern Mato Grosso, Brazil. Washington, Institute of Social Anthropology, 1953. (Publ. n. ํ 15)

RONDON, Cândido Mariano da Silva. Esboço gramatical; vocabulário; lendas e cânticos dos Indios Ariti (Pariú). Rio de Janeiro, C. N. P.I., 1948a - colaboração do doutorando João Barbosa de Faria.

Esbôço gramatical e vocabuláriio da lingua dos indios Bororó.

Algumas lendas e notas etnográficas da mesma tribo. Rio de Janeiro, C.N.P.I., 1948 b. - colaboração do doutorando João Barbosa de Faria.

ROQUETTE PINTO. Rondônia. 4. ․ ed. São Paulo, C. Ed. Nac., 1948. (Brasiliana n. 39)

SANTOS, Yolanda Lhullier dos. A Festa do Kwaríp entre os índios do Alto Xingu. Rev. De Antropologia. São Paulo, 4 (2):111-16, 1956. 
SCHADEN, Egon. Aculturação indígena. Ensaios sobre fatores e tendências da mudança cultural de tribos índias em contato com o mundo dos brancos. Rer de Antropologia. São Paulo, 13(1-2), jun. / dez,1965.

SCHMIDT, Max. Les Bakairi. Rev. Mus. Paulista. São Paulo, 1: 11-58, 1947.

SCHUlTZ, Harold. Lendas Waurá. Rev. Mus. Paulista. São Paulo, 16:21-149, 1665-66.

STEINEN, Karl von den. Entre os aborigenes do Brasil Central. Trad. le Egon Schaden. São Paulo, Departamento de Cultura, 1940. Separata da Rev. do Arquivo (34-43).

O Brasil Central. São Paulo, s. ed., 1942. (Brasillana, Grde. Form. v. 3) 


\section{Colofão}

\begin{tabular}{r|l} 
Formato & $17 \times 24 \mathrm{~cm}$ \\
Tipologia & Gatineau, SilDoulosIPA \\
Papel & $\begin{array}{l}75 \mathrm{~g} / \mathrm{m}^{2}(\text { miolo }) \\
\text { Cartão Supremo } 250 \mathrm{~g} / \mathrm{m}^{2}(\mathrm{capa})\end{array}$ \\
Impressão & $\begin{array}{l}\text { Setor de Reprografia da EDUFBA } \\
\text { Capa e Acabamento }\end{array}$ \\
Impressão BIGRAF \\
Tiragem
\end{tabular}

